\title{
Environmental Assessment of SP-100 Ground Engineering System Test Site Hanford Site, Richland, Washington
}

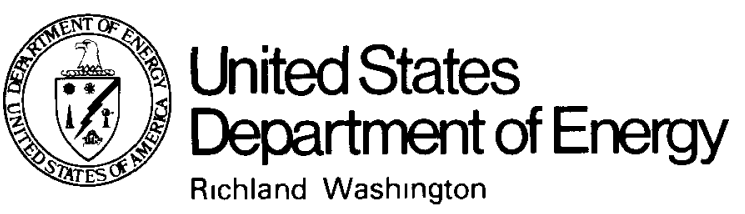




\section{DISCLAIMER}

This report was prepared as an account of work sponsored by an agency of the United States Government. Neither the United States Government nor any agency Thereof, nor any of their employees, makes any warranty, express or implied, or assumes any legal liability or responsibility for the accuracy, completeness, or usefulness of any information, apparatus, product, or process disclosed, or represents that its use would not infringe privately owned rights. Reference herein to any specific commercial product, process, or service by trade name, trademark, manufacturer, or otherwise does not necessarily constitute or imply its endorsement, recommendation, or favoring by the United States Government or any agency thereof. The views and opinions of authors expressed herein do not necessarily state or reflect those of the United States Government or any agency thereof. 


\section{DISCLAIMER}

Portions of this document may be illegible in electronic image products. Images are produced from the best available original document. 


\section{Environmental Assessment of SP-100 Ground Engineering System Test Site Hanford Site, Richland, Washington}

Date Published

December 1988

United States

(1/2) Department of Energy

Washington, DC 20545 
Blank Page 


\section{CONTENTS}

Page

Figures

viii

Tables

ix

1.0 PURPOSE OF AND NEED FOR ACTION $1-1$

1.1 PROPOSED ACTION AND NEED $1-1$

1.2 PURPOSE OF THIS DOCUMENT $1-1$

2.0 DESCRIPTION OF NATIONAL PROGRAM $2-1$

2.1 BACKGROUND ON NATIONAL EFFORTS 2-1

2.2 SCOPE OF GROUND ENGINEERING SYSTEM PROGRAM

2.3 SP-100 POWER SYSTEM CONCEPT SELECTION 2-3

2.3.1 SP-100 Power System Concept

Selection Process 2-4

2.3.2 Power System Concepts Considered 2-5

2.3.2.1 Reactor/Thermionics System 2-5

2.3.2.2 Reactor/Thermoelectrics System 2-5

2.3.2.3 Reactor/Stirling/Brayton Systems 2-6

2.3.2.4 Reactor Designs 2-7

2.3.3 Selected Power System Concept 2-9

2.3.3.1 Overview $2-9$

2.3.3.2 The Nuclear Subsystem 2-10

2.3.3.3 Space Subsystem 2-15

3.0 DESCRIPTION OF PROPOSED TEST SITE ACTION AND ALTERNATIVES 3-1

3.1 DESCRIPTION OF PROPOSED TEST SITE ACTION 3-1

3.1.1 Test Reactor System 3-1

3.1.2 Test Facility Operations 3-3

3.1.2.1 Overview of Program and Test

Site Schedule 3-3

3.1.2.2 Facility Qualification Testing
Program

3.1.2.3 Reactor Installation and Testing 3-4

$\begin{array}{ll}3.1 .2 .4 & \text { Reactor Handling Following } \\ \text { Testing } & 3-5\end{array}$

3.1.2.5 Decontamination and Decommissioning 3-6 
3.1.3 Test Site Description 3-6

3.1.3.1 Existing Facility 3-8

3.1.3.2 Secondary Heat Transport System 3-14

3.1.3.3 Vacuum Vessel 3-18

3.1.3.4 Containment Structure 3-18

3.1.3.5 Containment Isolation System 3-19

3.1.3.6 Process Gas Handling Systems 3-20

3.1.3.6.1 Vacuum System 3-20

3.1.3.6.2 Tritium Removal System 3-21

3.1.3.6.3 Containment Ventilation and Cell Atmosphere Control

3.1.3.6.4 Exhaust Monitoring System

3.1.3.6.5 Inert Gas Supply and Exhaust System

3.1.3.7 Test Article Handling System 3-23

3.1.3.8 Primary Lithium Fill and Drain

$3-25$ System

$\begin{array}{llr}3.1 .3 .9 & \text { Control and Data Systems } & 3-26 \\ 3.1 .3 .10 & \text { Safety Power Supply System } & 3-27\end{array}$

3.1.3.11 Auxiliary Systems and Structures 3-27

\subsubsection{Construction}

3.2 ALTERNATIVES TO THE PROPOSED TEST SITE ACTION 3-28

3.2.1 Test Site Selection 3-28

3.2.2 Hanford Alternatives to the Proposed Action 3-30

3.2.3 Pursue a No-Action Course (i.e., Do Not Ground-Test the SP-100 Reactor)

4.0 DESCRIPTION OF AFFECTED ENVIRONMENT

4.1 HANFORD SITE 4-1

4.1.1 Site Location and Regional Population 4-1

4.1.2 Regional and Site Activities 4-5

4.1.3 Socioeconomics $4-5$

4.1.4 Physical Environment 4-8

4.1.4.1 Geology and Topography 4-8

4.1.4.2 Hydrology 4-9

4.1.4.3 Seismicity $4-9$

4.1.4.4 Climatology $4-10$

4.1.4.5 Background Radiation 4-10 


\section{CONTENTS (Cont'd)}

4.1.5 Ecology 4-10

4.1.6 Archeology 4-13

5.0 ENVIRONMENTAL CONSEQUENCES $5-1$

5. 1 ENVIRONMENTAL CONSEQUENCES OF PROPOSED TEST SITE ACTION

$5-1$

5.1.1 Construction Impacts 5-1

5.1.2 Radiological Impacts, Startup Testing, and Normal Operations

$$
5-1
$$

5.1.2.1 Gaseous Releases 5-1

5.1.2.2 Radioactive and Mixed Waste Generation

$5-5$

5.1.2.3 Occupational Exposure

$5-6$

5.1.3 Nonradiological Impacts, Startup Testing, and Normal Operations

$5-7$

5.1.3.1 Thermal Discharges 5-7

5.1.3.2 Hazardous Materials 5-7

5.1.3.3 Hazardous and Nonradiological
Solid Waste Generation

5.1.4 Potential Accident Impacts 5-9

5.1.4.1 Unirradiated Fuel Handling Accident 5-10

5.1.4.2 Irradiated Fuel Handling Accident Following Cooldown

5.1.4.3 Accidental Tritium Release

$5-11$

$5-12$

5.1.4.4 Secondary Coolant System Sodium Leak and Fire

5.1.4.5 Lithium Leak

$5-13$

$5-14$

5.1.5 Consequence of a Severe Reactor Accident 5-15

5.2 SOCIOECONOMIC EFFECTS OF THE PROPOSED ACTION 5-16

5.3 DECONTAMINATION AND DECOMMISSIONING 5-17

5.4 RELATIONSHIP OF PROPOSED ACTION TO LAND-USE PLANS 5-17

5.5 IRREVERSIBLE AND IRRETRIEVABLE COMMITMENTS OF RESOURCES

6.0 RADIOLOGICAL RISK ASSESSMENT OF POTENTIAL SP-100 USE IN SPACE

6.1 INTRODUCTION 6-1

6.2 SAFETY PROCESS $6-2$

6.3 SAFETY FEATURES 6-3 
6.3.1 Safety of Unirradiated 235U Fuel 6-3

6.3.2 Ensured Shutdown in Accident Scenarios 6-4

6.3.3 Diverse and Redundant Shutdown Mechanisms 6-4

6.3.4 Intact Reentry and Impact 6-4

6.3.5 Loss-of-Coolant Accident Protection 6-5

6.4 ANALYTICAL APPROACH 6-5

6.5 SUMMARY OF RESULTS $6-10$

7.0 PERTINENT LAWS, REGULATIONS, AND GUIDELINES 7-1

7.1 DOE Order 5480.1A, "Environmental Protection, Safety, and Health Protection Programs for DOE Operations," Chapter XI, "Requirements for Radiation Protection" (as supplemented)

7.2 Code of Federal Regulations, 40 CFR 50, "National Primary and Secondary Ambient Air Quality Standards"

7.3 Code of Federal Regulations, 40 CFR 61, "National Emission Standards for Hazardous Air Pollutants"

7.4 Code of Federal Regulations, 40 CFR 141, "National Drinking Water Regulations"

7.5 Code of Federal Regulations, 40 CFR 260-268, "Resource Conservation and Recovery Act Regulations"

7.6 Washington Administrative Code, Title 18, Chapter 173-400, "Washington State Air Pollution Control Regulations" and General Regulation 80-7 of the Benton-Franklin-Walla Walla Air Pollution Control Authority

7.7 Code of Federal Regulations, 40 CFR 302, "Designation, Reportable Quantities, and Notification"

7.8 Washington Administrative Code, Title 18, Chapter 173-303, "Washington State Dangerous Waste Regulations"

7.9 Washington Administrative Code, Title 18, Chapter 173-480, "Ambient Air Quality Standards and Emission Limits for Radionuclides" and WAC Chapter 402-80, "Monitoring and Enforcement of Air Quality and Emission Standards for Radionuclides" 7-4

7.10 Transportation Regulations

8.0 AGENCIES CONSULTED $\quad 8-1$

9.0 ACRONYMS, ABBREVIATIONS, AND CONVERSIONS 9-1 
APPENDIX A CALCULATION OF RADIATION DOSES AND CONVERSION OF DOSES TO HEALTH EFFECTS

APPENDIX B HAZARDS IDENTIFICATION ANALYSIS

$B-1$

APPENDIX C SP-100 ACUTE RELEASE DOSE ANALYSIS DOCUMENTATION

C-1

APPENDIX D SP-100 CHRONIC RELEASE DOSE ANALYSIS DOCUMENTATION

D-1

APPENDIX E SP-100 GROUND ENGINEERING SYSTEM REACTOR TEST SITE SELECTION ENVIRONMENT FACTORS

$E-1$

APPENDIX $F$ MEMORANDUM: RADIATION STANDARDS FOR PROTECTION OF THE PUBLIC IN THE VICINITY OF DOE FACILITIES

APPENDIX G CONCEPT SELECTION

$F-1$ APPENDIX H ENV IRONMENTAL CONSEQUENCES OF A SEVERE (BEYOND DESIGN BASIS) REACTOR ACCIDENT AT THE SP-100 TEST SITE 


\section{FIGURES}

Figure

Page

1.1 SP-100 GES Facility 1-2

2.1 Reactor Core Cross Section 2-12

2.2 Reactor Power Assembly 2-13

2.3 Reactor and Space Subsystems in Deployed

Configuration

3.1 Test Reactor System 3-2

3.2 SP-100 GES Preliminary Equipment Arrangement
in the Hanford Site 309 Building

3.3 GES Test Reactor Facility (309 Building) 3-9

3.4 SP-100 GES Process Cells (Below Grade) 3-10

3.5 SP-100 System Overview 3-13

3.6 Existing Unused FFTF Closed Loop Dump Heat Exchangers. One Will Be Used for SP-100 GES Test Heat Rejection 3-15

3.7 Existing 309 Containment Building and Attached Structures

3.8 SP-100 GES Test Article Handling System 3-24

4.1 Location of Hanford Site Within Washington State 4-2

4.2 Hanford Site Details 4-3

4.3 Hanford 300 Area Details 4-4

4.4 83-km (50-mi) Radius from Hanford 300 Area 4-7

4.5 Hanford Site Earthquake Hazard 4-11

4.6 Hanford Site Wind Hazard 4-12

5.1 Tritium Release Scenarios 5-3 


\section{$\underline{\text { TABLES }}$}

Table

Page

4.1 Population Distribution for 1990 Within 83-km (50-mi) Radius of Hanford 300 Area by Population Grid Sector

5.1 Annual Airborne Radioactive Material Released from Light Water Reactors (1981), FFTF (1984), and SP-100 GES Test (Projected)

5.2 Summary of Radiological Accident Analyses

and Consequences for Extremely Unlikely Events

6.1 Mission Event Tree Summary -- SP-100 SRPS Mission Hazards

6.2 SP-100 Failure Probabilities Assumed for Risk Analysis

6.3 Reactor Source Term Types and Release Fractions

$6-9$

6.4 SP-100 Mission Health Effects Summary 
1.0 PURPOSE OF AND NEED FOR ACTION

1.1 PROPOSED ACTION AND NEED

The U.S. Department of Energy (DOE) proposes to modify an existing reactor containment building [decommissioned Plutonium Recycle Test Reactor (PRTR) 309 Building] to provide ground test capability for the prototype SP-100 reactor. The 309 Building (Figure 1.1) is located in the 300 Area on the Hanford Site in Washington State.

The DOE, the National Aeronautics and Space Administration (NASA), and the U.S. Department of Defense (DOD) have entered into an agreement to jointly develop and fund space nuclear reactor power system technology. The goal is to develop safe, compact, lightweight, durable, space reactor power system technology providing electrical power in the range of tens to hundreds of kilowatts to make possible a broad class of emerging military and civil space missions in the early to mid-1990s and beyond. The DOE has primary responsibility for developing and ground testing the nuclear subsystem. As part of this program, it is proposed that the SP-100 test reactor (maximum rating of 2.5 megawatt-thermal [MWt]) be tested in the existing 70-MWt PRTR containment building. A ground test of a prototype reactor is necessary to demonstrate technology readiness of this major subsystem before proceeding with the flight system development and demonstration.

\subsection{PURPOSE OF THIS DOCUMENT}

The National Environmental Policy Act (NEPA) requires that Federal agencies assess the potential impacts that their actions may have on the environment. This Environmental Assessment describes the consideration given to environmental impacts during reactor concept and test site selection, examines the environmental effects of the DOE proposal to ground test the nuclear subsystem, describes alternatives to the proposed action, and examines radiological risks of potential SP-100 use in space. 


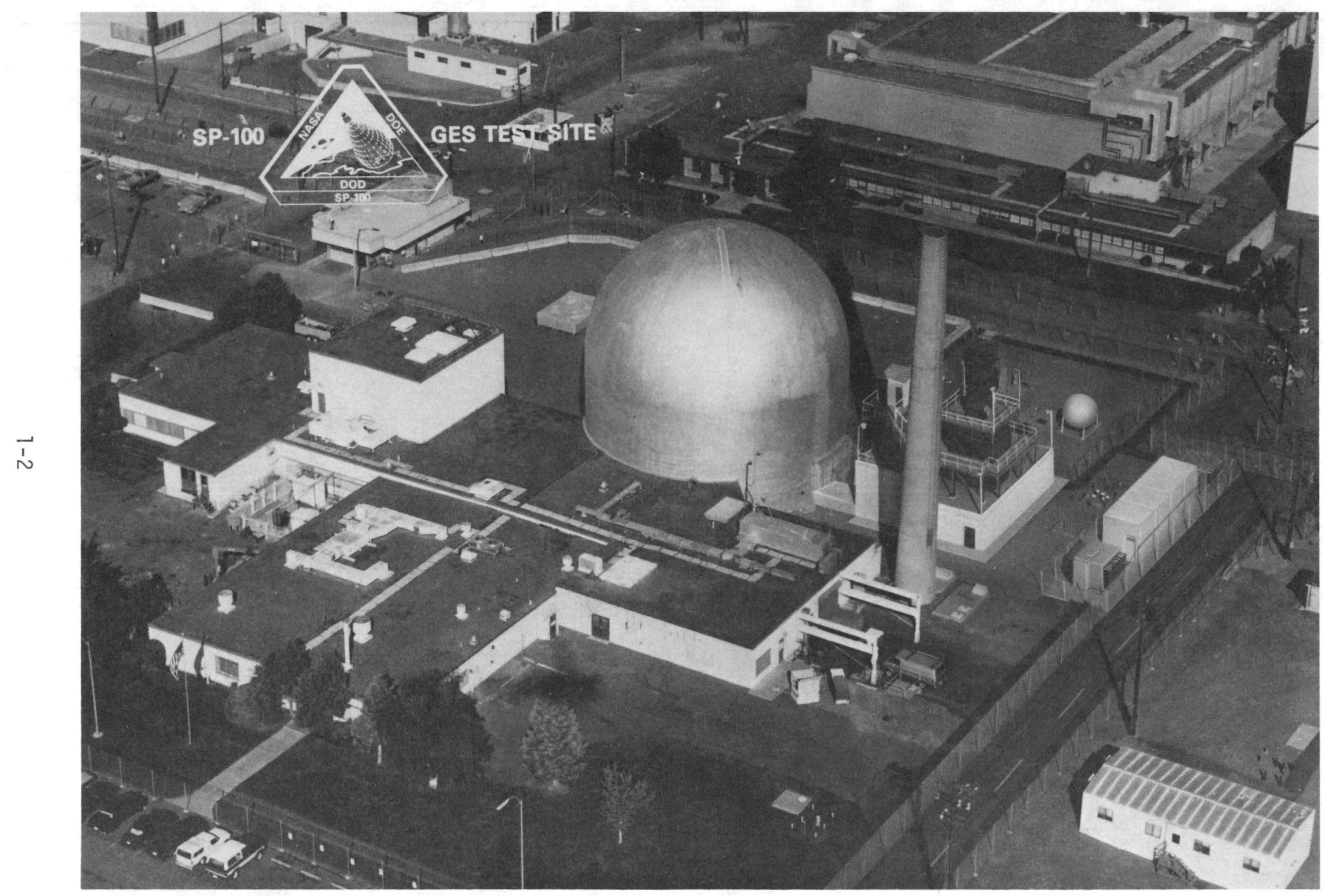

FIGURE 1.1. SP-100 GES Facility. 
The DOE will use the information and analyses presented here to determine whether the proposed action would have significant impacts on the environment. If the impacts are determined to be significant, a more detailed document called an Environmental Impact Statement (EIS) will be prepared. If the impacts are not judged to be significant, the DOE may issue a Finding of No Significant Impact (FONSI) and implement the proposed action. These procedures and documents are defined in regulations issued by the Council on Environmental Quality (CEQ) in Title 40, Code of Federal Regulations, Parts 1500 through $1508^{(1.1)}$ and in DOE Guidelines for compliance with NEPA (52 FR 47662, December 15, 1987). (1.2) 
2.0 DESCRIPTION OF NATIONAL PROGRAM

2.1 BACKGROUND ON NATIONAL EFFORTS

The SP-100 Program is jointly sponsored by DOE, NASA, and DOD for the purpose of developing a nuclear reactor power system that can either enhance or enable future civilian and military space missions. The program is directed to develop space reactor technology to provide electrical power in the range of tens to hundreds of kilowatts. The SP-100 Program is laid out in three phases: (I) Technology assessment and advancement; (II) Technology flight readiness; and (III) Flight system production, qualification, and application.

Phase I, which ended in FY-1985, investigated various space power system concepts and established their technical and safety feasibility through the assessment and advancement of the technologies on which the concepts were based. These efforts resulted in the selection of one concept for further development.

Phase II was initiated in FY-1986 and consists of four functional SP-100 elements: (1) Ground Engineering System (GES) Development, (2) Advanced Aerospace Technology, (3) Civil Missions Analysis and Requirements Definition, and (4) Military Missions Analysis and Requirements Definition. The first functional element is managed within the DOE Office of Defense Energy Projects by the SP-100 GES Program Office. Functional elements 2 and 3 are the responsibility of NASA's Office of Aeronautics and Space Technology. The Strategic Defense Initiative Organization (SDIO) is responsible for functional element 4 and uses the United States Air Force (USAF) as the executing organization. 
Phase III activities may be initiated prior to the completion of Phase II depending on mission decisions and funding levels. The first application of an SP-100 power system in space is currently planned as a flight experiment that will couple the power source to an arcjet propulsion unit and other scientific experiments that require more electrical power than previously available. These advanced experiments have not yet been defined nor have the specific mission details. Initial planning for the flight experiment is scheduled to begin in FY-1989 with detailed development to start in FY-1990 for a proposed launch in FY-1996.

In addition to the flight experiment, the SP-100 electrical power system is envisioned as the preferred power source for a variety of potential civil and military space missions. Such missions will be able to benefit from one or more of the special attributes of a nuclear reactor electrical power source. These attributes include independence from solar energy, high power to mass and surface area ratios, long lifetime, and high survivability. Some missions may not be possible at all without a power source that provides some combinations of capabilities from a nuclear reactor power system. 0thers would be possible but either at reduced levels of performance or at greater costs. System level trade-off studies and evaluations may be performed in order to tailor the power system features to each specific mission and to spacecraft integration requirements.

Potential mission applications for an SP-100 space reactor power system are many and diverse as a result of the flexibility and scalability in the system design. Missions that may employ the SP-100 power system include deep space probes, manned lunar and Mars bases, electrical propulsion for orbital transfer and interplanetary vehicles, space-based radar for surveillance, tracking and air/ocean traffic control, direct broadcasting, and global communications. 


\subsection{SCOPE OF GROUND ENGINEER ING SYSTEM PROGRAM}

The DOE is responsible for development and ground testing of hardware usable for future space missions. This responsibility encompasses generic flight system design, ground engineering subsystems design, engineering development, and ground testing to validate the readiness of the system technology for dedicated flight use. The generic flight system is a $100-k$ We space reactor power system point design that provides the basis for GES activities. This design is adapted as necessary for ground testing. The generic flight system design will also be used as the baseline for power level scaling and system hardening. It will be updated as appropriate to incorporate results from the GES testing program, including component, subsystem, assembly level development, performance, safety, and lifetime/reliability testing. This aspect of the program will also demonstrate industry's ability to manufacture the power system components, subsystems, and assemblies.

The major assembly level nuclear test to be conducted in the SP-100 GES Program is referred to as the Nuclear Assembly Test (NAT). The NAT is designed to validate the performance of the nuclear assembly by up to 2 years of reactor operation conducted in a vacuum chamber within a reactor containment structure to simulate space conditions. The test article will include the SP-100 reactor, instrumentation and control, primary heat transport 10op, and radiation shield subsystems as prototypical of the flight system design as practical. The performance of this NAT is the principal issue addressed in this environmental assessment.

\section{$2.3 \quad$ SP-100 POWER SYSTEM CONCEPT SELECTION}

In August 1985, the SP-100 Steering Committee selected the fast reactor/ thermoelectric power conversion system concept for engineering development and ground testing during the Phase II of the SP-100 Program. This selection was the result of a well-defined technology assessment effort and a formal selection process conducted during Phase I of the program. This section summarizes the space reactor power system concept selection process, reviews the power concepts considered, and provides a detailed description of the generic flight system. A more detailed discussion of all these topics may be found in Appendix G. 


\subsubsection{SP-100 Power System Concept Selection Proces S}

The SP-100 space reactor system concept selection process involved several steps. The first step consisted of the development and approval of an SP-100 System Selection Process that identified a Prioritized Set of Competing Design Characteristics (PCDC) and the weighting factors for each. The PCDCs express levels of confidence that the nuclear power system can:

- Meet or exceed safety and safeguards requirements for a system to be launched in space

- Meet design goals specified for concept selection

- Accommodate varying mission power requirements

- Survive various environmental and possible hostile actions

- Be developed in a timely, cost-effective manner

- Be user friendly and require minimal ground support

- Be easy to operate, reliable, and responsive in meeting operations requirements.

Al1 design characteristics were evaluated from both the perspectives of prelaunch activities and ultimate use in space. Though specific missions were not identified, the decision process focused on ultimate use and not around the interim testing to take place in the GES element of the program.

The second step in the selection process was to distribute the PCDC and specific design criteria to the system design contractors with a request to prepare evaluations of their designs. The request informed the contractors that the final system design should meet these requirements and that the information they submitted would be used in the system selection process.

As the third step in the process, the three system designers submitted their surety evaluations as required by the selection procedure. The four candidate power system concepts considered are described in the following section. 


\subsubsection{Power System Concepts Considered}

The four power system concepts that were considered included reactor/ thermionics, reactor/thermoelectrics, reactor/Stirling Cycle, and reactor/ Brayton Cycle. The reactor/thermoelectric concept was judged to be superior to the other concepts for the SP-100 program. A general description of the four candidate power system concepts and their major advantages and disadvantages is provided below.

\subsubsection{Reactor/Thermionics System}

The in-core thermionics (TI) concept was developed by both General Atomic Technologies and Martin Marietta Aerospace. The primary advantages of the TI system is the relatively high efficiencies ( 9 to $11 \%$ ) and the high reject temperatures. The thermionic element consisted of uranium-oxide $\left(\mathrm{UO}_{2}\right)$ fue 1 operating at a temperature of $1750 \mathrm{~K}$ surrounded by a tungsten emitter. The sheath insulator was $\mathrm{Nb}-\mathrm{YAG}-\mathrm{Nb}-1 \% \mathrm{Zr}$ operating at a temperature of $1100 \mathrm{~K}$ with \pm 30 volts $(V)$. The maximum fuel burnup was $2 \%$. Sodium-potassium (NaK) was used for the system coolant. The reactor outlet temperature was $1100 \mathrm{~K}$. The system was launched with the coolant in the liquid state and did not require thaw in orbit. Disadvantages of launching liquid are the requirement to double contain the liquid if launched on the shuttle and the possible requirement to input energy to keep it liquid during launch. The system was designed with a single electromagnetic (EM) pump and a single thermoelectricelectromagnetic (TEM) pump, where one out of two was required to perform the mission. The NaK transferred the waste heat to a sodium heat pipe radiator with $\mathrm{Nb}-1 \% \mathrm{Zr}$ armor. There was a $25-\mathrm{m}$ separation between the center of the core and the user plane. The system was designed to deliver $100 \mathrm{~V} d c$ to the user module.

\subsubsection{Reactor/Thermoelectrics System}

The reactor/thermoelectrics (TE) concept was developed by General Electric. The primary advantages of the TE system are the large available database and the versatility of the reactor concept to be used with alternate power 
conversion systems other than TES. Uranium nitride (UN) was proposed as the reactor fuel with a tungsten barrier and $\mathrm{Nb}-1 \% \mathrm{Zr}$ cladding. The fuel was to operate at a temperature of $1400 \mathrm{~K}$ with a maximum burnup of $6 \%$. Lithium was the primary coolant; the system was designed to be launched with the lithium solid, thereby requiring thaw while in orbit. This was considered advantageous because it simplified launch procedures. The reactor outlet temperature was $1350 \mathrm{~K}$. The coolant was circulated by three TEM pumps, where two out of three were required. The TE cell was a hybrid of silicon and germanium. The TE cells were conductively coupled to the primary heat transport loop and the potassium heat pipe radiator. Titanium/berylliumaluminum material was to be used for armoring the heat pipe radiator. The system separation distance from the user was $40 \mathrm{~m}$, and the system delivered $200 \mathrm{~V}$ dc to the user module.

\subsubsection{Reactor/Stirling/Brayton Systems}

The reactor/Stirling cycle concept with an alternative Brayton cycle concept was developed by Rockwell International's Rocketdyne Division. The primary advantage of either the Stirling or Brayton concept is the high efficiency of the power conversion units. Both the Stirling and Brayton concepts used the same basic reactor technology and differed in the heat exchanger, secondary loop, and power conversion units. The reactor core used UN fuel clad in $\mathrm{Nb}-1 \% \mathrm{Zr}$ cladding with a tungsten 1 iner. The maximum fuel burnup was $1.5 \%$. The reactor outlet temperature was $1150 \mathrm{~K}$ for the Stirling system and $1350 \mathrm{~K}$ for the Brayton system. The primary coolant was lithium, which was solid at launch. The primary coolant loop had three TEM pumps, where two of the three were required. Both concepts delivered $400 \mathrm{~V}$ dc power to the user and were separated from the user plane by a 40-m boom.

The Stirling system used a secondary NaK liquid loop to carry the heat to the mercury heat pipe radiator made of stainless steel with beryllium-aluminum armoring. Four superalloy, opposed-piston engines were used, each capable of generating $37 \mathrm{kWe}$, where three out of four were required. The temperature of the coolant to the engine was $1100 \mathrm{~K}$. 
The Brayton system had a helium-xenon secondary gas loop to the mercury heat pipe and water heat pipe radiator. The heat pipes were fabricated from stainless steel and had copper/beryllium-aluminum armor. Four refractory metal Brayton engines were each capable of generating $37 \mathrm{kWe}$. Three out of four were required to generate $100 \mathrm{kWe}$.

\subsubsection{Reactor Designs}

Selection of a reactor design required consideration of the power conversion system heat source requirements, the resulting fuel and operating conditions, material compatibility, and overall system optimization. In all concepts proposed, a fast reactor design was selected in order to achieve the most compact reactor possible. This had a significant effect on reducing the mass of the overall power system.

A compact fast reactor requires the use of highly enriched fuel. Uranium was the clear choice of fuel from the perspectives of availability and safety. In the case of the reactor/thermionics power system concept, a $\mathrm{UO}_{2}$ fueled core was proposed because of the high fuel operating temperature required by the thermionic elements. The other power system concepts, however, were able to use UN fuel because of the lower fuel operating temperature required by the power conversion systems. The material characteristics of this fuel (thermal conductivity and uranium atom density) allowed a highly compact reactor design.

Selection of the reactor coolant was highly dependent on the reactor fuel composition and required coolant operating conditions. The required operating temperature for the reactor coolant in the thermionics power system concept was low enough to allow the use of NaK. The other power system concepts selected 1 ithium as the reactor coolant because of their requirement for higher coolant temperatures and material compatibility with UN fuel. Each of these coolants has its unique advantages and disadvantages as discussed in the concept descriptions. 
Each material or technology within the competing power system concepts was compared to other potential choices in order to select those that could best meet the SP-100 requirements and objectives. The following specifications were selected as the basis for the development of the SP-100 space reactor power system. They were specifically chosen because they could best meet the SP-100 requirements end objectives. A review of the competing technology or materials will not be included in this section, but each material or technology was traded off against other potential choices. The following specifications were included in the Request For Proposal (RFP) for the SP-100 GES program:

1. Uranium-nitride fuel

-- High thermal conductivity/low temperature drop across the fuel

-- High uranium atom density/compact core

- Database at temperature

-- Compatible with lithium coolant/no adverse chemical reactions

-- Uranium-oxide will not be used in this application because it is chemically incompatible with lithium, reduced uranium density, and low thermal conductivity.

2. Niobium-based alloy

-- Only commercially available refractory metal at reasonable cost

-- Refractory properties/high-temperature operation

-- Compatible with lithium

3. Lithium coolant

-- Frozen at launch temperatures (simplified launch procedures)

-- Excellent heat capacity (took from a fourth to a third less pump power for equivalent heat removal)

-- Low pressure at temperature

- NaK was not chosen because of the high pumping power required at these operating conditions (1350 K)

4) SiGe-GaP thermoelectric material

-- High figure of merit (10 to $15 \%$ higher performance over SiGe for the same $\Delta T$ ). 
The three major discriminators among the concepts were performance, growth capability, and cost and schedule. Within this framework, the static system concepts ( $T I$ and TE) consistently ranked better than dynamic system concepts (Brayton and Stirling), but the two static systems had mixed results.

The concept evaluation committee ranked the reactor/TE concept as having the highest probability of meeting the performance lifetime and reliability requirements and of completing Phase II development by 1991. The in-core TI system was evaluated as having the greatest potential for growth to higher power levels but, given its current level of technology readiness and the planned development schedule, it was rated as having greater risk in meeting the performance lifetime and reliability goals. This was particularly true for the TI system because it required in-core testing that could impact both programmatic cost and schedule.

Therefore, based upon the defined discriminators and the programmatic requirements, the concept evaluation committee recommended the TE concept for development and testing with the SP-100 Phase II GES effort.

The power level was also set by the System Selection Committee at $300 \mathrm{kWe}$ for development during the SP-100 GES. It was set at $300 \mathrm{kWe}$ to meet a potential USAF mission envisioned in the early 1990s. Since that decision, the level was shifted to $100 \mathrm{kWe}$ for the GES to reflect a change in power requirements for potential missions.

\subsubsection{Selected Power System Concept}

\subsubsection{Overview}

The SP-100 power system design is based upon a set of key requirements. The technical requirements were established by DOE, DOD, and NASA in response to performance and functional needs that are projected by mission planners. The system is designed to generate $100 \mathrm{kWe}$ for 7-yr full-power operation over a 10-yr period. The SP-100 is being designed to enable launch on the shuttle within a third of the shuttle bay at the 100-kWe power level. 
The design consists of two major subsystems: the nuclear subsystem and the space subsystem. The nuclear subsystem or assembly is further partitioned into four major elements: the SP-100 nuclear reactor, the radiation shield, the primary heat transport, and instrumentation/control. The space subsystem consists of power conversion, waste heat rejection, power conditioning/control, and support structure subsystems.

The SP-100 reactor generates $2.4 \mathrm{MWt}$ * of thermal energy to produce $100 \mathrm{kWe}$ for 7-yr full-power operation. The SP-100 employs two coolant loops: a single primary loop that transfers heat from the reactor to the heat exchanger/power conversion unit and 12 independent secondary systems that remove the waste heat and transfer it to the potassium heat pipe radiator. Both the primary and secondary coolant are pumped by TEM pumps. The thermal energy is converted directly into electricity by static TE power conversion cells. A radiation shield, located directly beneath the reactor, is used to reduce the amount of neutron and gamma radiation at the user interface. The power system is separated from the main spacecraft by a boom to reduce both radiation and thermal impact to the user. The power conditioning and control system is located near the user's interface and consists of the system controller, batteries, and shunt radiator.

\subsubsection{The Nuclear Subsystem}

The system requirements drive the design of the nuclear subsystem or assembly. The SP-100 nuclear reactor is designed to generate 2.4 MWt at full power for $7 \mathrm{yr}$, which influences the core size, enrichments zones, and burnup levels. The reactor must have two independent and diverse methods to ensure that the reactor will remain inoperable during transportation and launch and for permanent shutdown at the end of the mission. The reactor system must have a means of removing the decay heat to ensure continued structural integrity of the system for boost to higher orbit in the unlikely event that the reactor should experience a Loss-of-Coolant Accident (LOCA). In the case of

\footnotetext{
*The test facility is being designed for a 2.5-MWt system. This will accommodate the 2.4-MWt nuclear assembly.
} 
an accidental reentry, the reactor must remain intact and effectively bury itself upon impact with the earth. All of these requirements have direct effects on the design of the reactor subsystem.

The SP-100 is a fast reactor with highly enriched UN fuel. The reactor core consists of 24 hexagonal-shaped assemblies with 37 fuel pins per assembly (see Figure 2.1) and six partial assemblies with 22 pins around the outer edge that bring the hexagonal shape closer to a circular form. The core contains a total of 978 fuel pins plus 42 auxiliary cooling loop bayonets. Fuel pins are separated from each other and from the wall of the hex assembly by a wire-wrap spacer. The fuel pins have an upper plenum region to contain fission products. The fuel assemblies are encased within an integral honeycomb core structure that maintains the fuel pin spacing and helps transfer heat to the reactor vessel in the event of a LOCA.

The fueled region of the core is $41.5 \mathrm{~cm}(16.3 \mathrm{in.})$ high. The effective core diameter is $32.5 \mathrm{~cm}(12.8 \mathrm{in}$.$) . The reactor vessel outside diameter is$ $35.7 \mathrm{~cm}(14.1 \mathrm{in.})$. The fuel pellet diameter is $0.648 \mathrm{~cm}(0.26 \mathrm{in.})$, and the pin diameter is $0.775 \mathrm{~cm}(0.31 \mathrm{in.})$.

The reactor will have the following approximate performance conditions for operation: coolant flow rate $11 \mathrm{~kg} / \mathrm{s}$, pressure drop across the core 2.25 psi, coolant inlet temperature $1270 \mathrm{~K}\left(2286^{\circ} \mathrm{R}\right)$, and coolant outlet temperature $1325 \mathrm{~K}\left(2385^{\circ} \mathrm{R}\right)$.

Heat pipes are used to thaw the coolant in the primary coolant loop during reactor startup. The evaporator sections of the sodium thaw heat pipes are in thermal contact with the reactor vessel and are conductively strapped to the hot-side ducts of the TEM pumps. The thaw heat pipes also furnish heat to the thaw cavity enclosing the secondary ducting and the power conversion assemblies.

An auxiliary coolant loop (ACL) is an integral part of the reactor design. Its function is to remove decay heat in the event of a LOCA in order to limit the maximum temperature of the fuel to less than $2000 \mathrm{~K}\left(3600^{\circ} \mathrm{R}\right)$. It provides a cooling loop, totally independent of the normal heat removal 


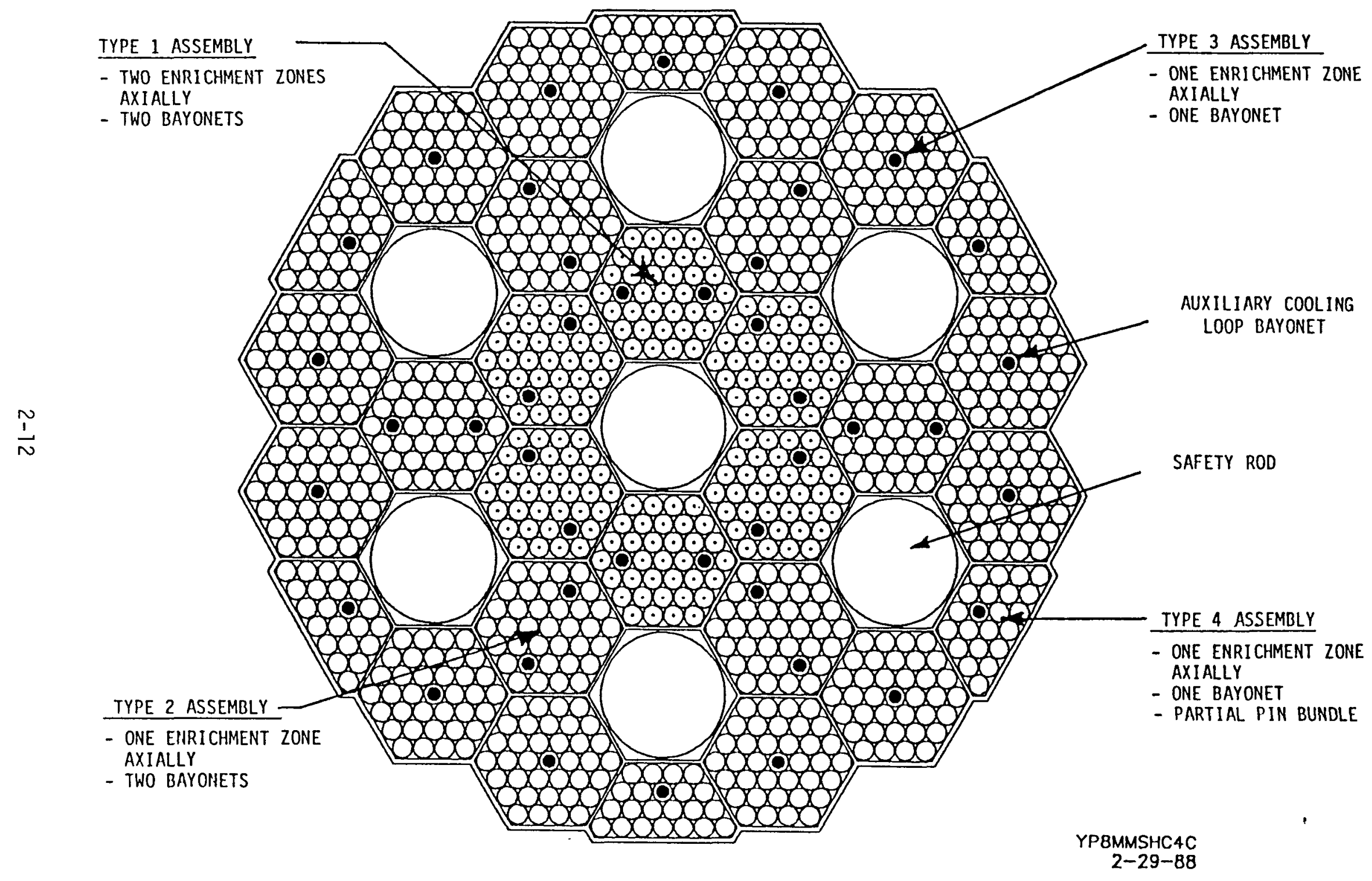

FILURE 2.1. Reactor Core Cross Section. 
system, to ensure adequate decay heat removal. Heat removal is achieved by 42 in-core tubes (bayonets) located throughout the core (see Figure 2.1). The lithium coolant passes through the core into a collection manifold from which it is pumped to an independent radiator for rejection of heat to space.

A reentry thermal protection shield is attached to the outside of the reactor vessel to ensure that the reactor will withstand the aerodynamic heating of reentry and remain intact (see Figure 2.2). The reentry thermal protection shield is aerodynamically shaped to ensure a predictable and stable reentry of the reactor and radiation shield.

There are two independent shutdown systems on the SP-100 reactor: internal safety rods and external hinged reflectors. The in-core safety rods (Figure 2.1) ensure that the reactor remains subcritical during prelaunch,

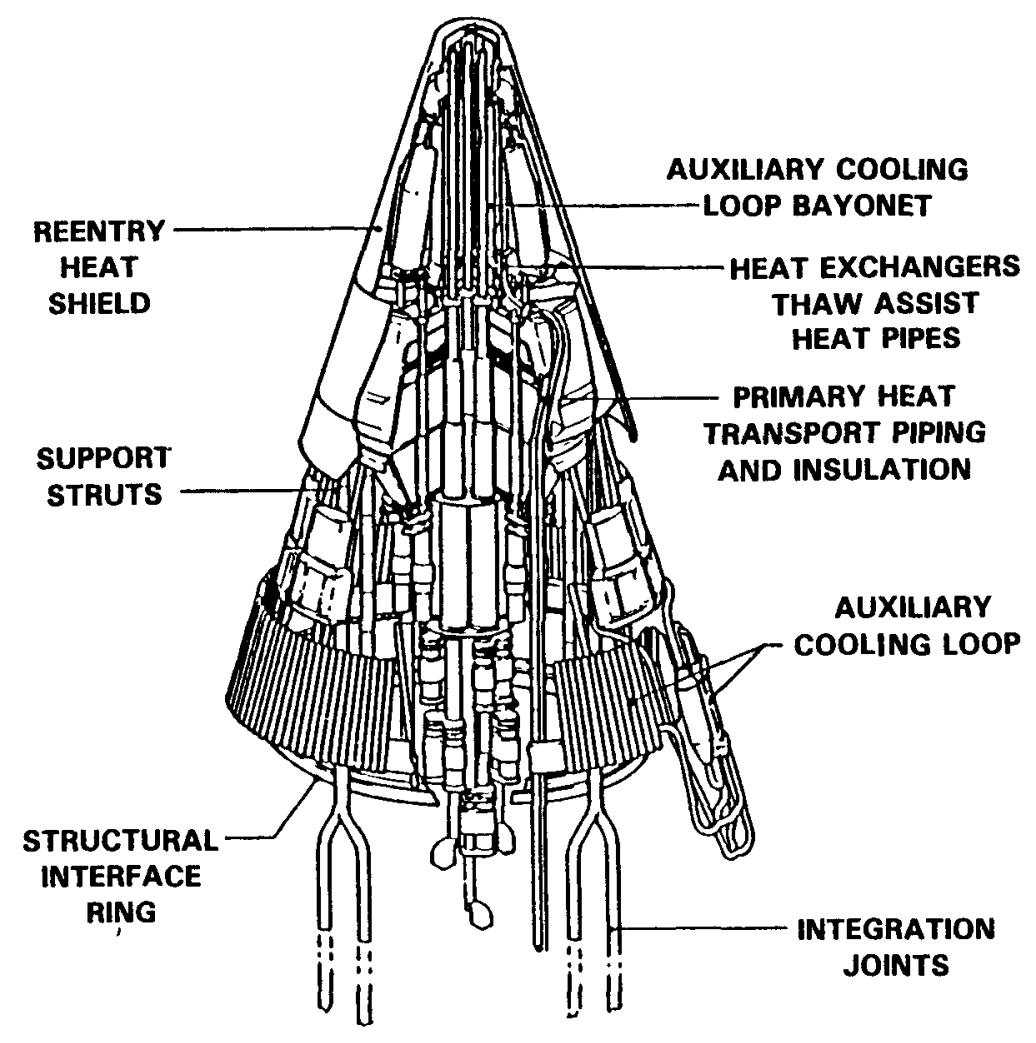

38811115.2

FIGURE 2.2. Nuclear Assembly (subsystem). 
launch, and postmission events. These rods are operated by moving boron carbide $\left(B_{4} C\right)$ absorber rods inside structural thimbles to either the full-in or full-out position. Beryllium oxide (Be0) followers replace the $\mathrm{B}_{4} \mathrm{C}$ as the absorber sections are removed from the core. Each shutdown rod takes up the equivalent area of a single fuel assembly. The 12 reflector control segments are used to bring the reactor critical after all of the in-core absorber rods are withdrawn and control the reactor over the 7-yr design lifetime by compensating for fuel burnup and swelling. The reflector elements achieve reactor control by moving the beryllium reflector segment toward or away from the reactor vessel, thereby controlling neutron leakage from the core. The reflector elements consist of BeO contained within a niobium- $1 \%$ zirconium ( $\mathrm{Nb}-1 \% \mathrm{Zr}$ ) she 11 .

A radiation shield is adjacent to the reactor between the reactor and the payload. The purpose of the shield is to reduce the level of gamma and neutron radiation at the user plane to an acceptable level and to protect the power system components and instrumentation. The user plane is assumed to be a $4.5-\mathrm{m}(15-\mathrm{ft})$ disc at a separation distance of $22.5 \mathrm{~m}(74 \mathrm{ft})$ from the center of the reactor core. The radiation shield is fabricated from lithium hydride $(\mathrm{LiH})$ pressed into a stainless-steel honeycomb to attenuate neutrons. Tungsten plates are used primarily to attenuate gamma radiation, beryllium is used to transfer heat to the outer surface of the shield, and titanium is used to contain the shield.

The primary coolant loop consists of six inlet and six outlet loops symmetrically located around the bottom of the reactor vessel. The low-pressure coolant is directed into the core where heat is removed. It is then pumped to the heat exchanger/power conversion unit and back to the core.

Thermoelectric-electromagnetic pumps are used to circulate the liquid lithium in both the primary and secondary side heat transport loops. The TEM pumps are self-energized, DC conduction, EM pumps. They use TE materials to internally generate the electric power needed for them to operate. The temperature difference required to produce electricity within the TE elements is provided by the temperature difference between the primary and secondary coolant loops. Hence, flow responds to temperature in a self-regulated way. 


\subsubsection{Space Subsystem}

The space subsystem is divided into 12 independent power conversion loops. The system is designed such that 11 of the 12 loops can generate the full $100 \mathrm{kWe}$.

Waste heat from the power conversion assembly and TEM pumps is transferred by the secondary coolant loops to the radiator assembly and rejected to space (see Figure 2.3). A cold-side heat exchanger transfers the waste heat from the power conversion subsystem to the lithium coolant of the heat rejection subsystem. The secondary coolant is circulated by the dual-throat TEM pumps to the radiator assembly through titanium piping.

The lithium flows through the fixed radiator panel ducting, through a flexible joint, and through the deployed radiator panel supply duct. The supply duct then transitions to the return duct. The lithium flows back to

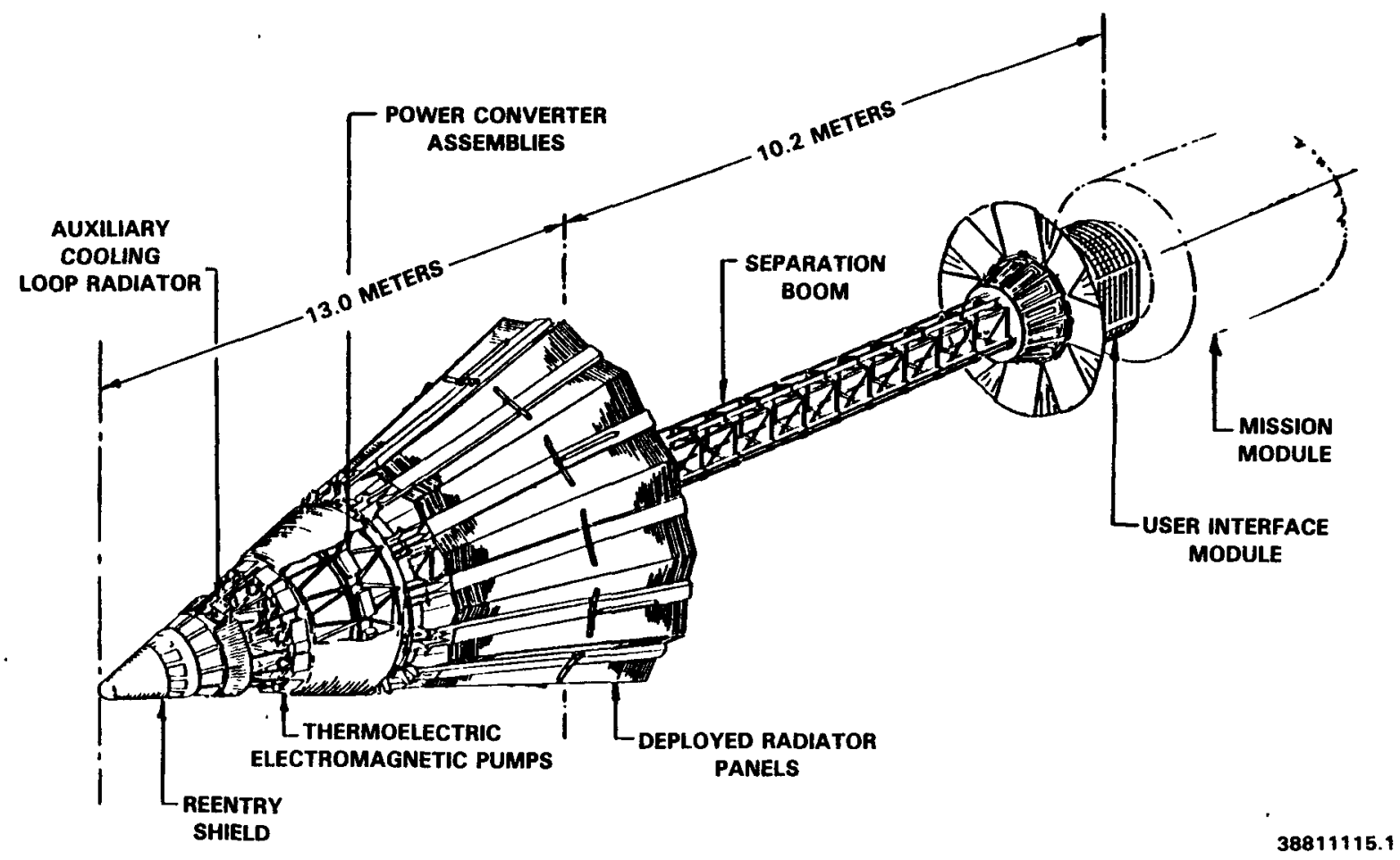

FIGURE 2.3. Reactor and Space Subsystems in Deployed Configuration. 
the TEM pump while transferring its heat through the titanium-beryllium ducting into the titanium-beryllium heat pipes. The heat pipes have titanium foil wicks that distribute the heat along the radiator where it is rejected to space. The heat pipes are attached to both the supply and return ducts. Bleed holes between the supply and return ducts provide a circulation path for the lithium as it thaws during reactor startup. All exposed heat pipes and lithium ducting have armor to provide protection from micrometeroid penetration.

The coolant is circulated by a TEM pump to the power conversion assembly (PCA)/heat exchanger. Each PCA is made up of thermoelectric converter assemblies (TCA) mounted in a common structural support frame and joined by tubing manifolds that permit parallel flow of fluid through each of the six sets of heat exchangers. Each TCA consists of a layered assembly of one hot-side heat exchanger and two cold-side heat exchangers with arrays of TE cells between hot-side and cold-side heat exchangers. Each TCA has two arrays of cells called thermopiles. The 60 TE cells within each thermopile are electrically connected.

Each TE cell, consisting of a TE module, compliant pads, and electrical insulators, is conductively bonded between hot and cold heat exchangers. The electrical insulators are bonded directly to the heat exchangers on each side and isolate the cell from ground, while the compliant pads on each side permit differences in thermal expansion and thermal distortions to be accommodated. The thermoelectric module includes 32 couples of $n$-type and p-type materials. Couples are interconnected within the module by electrodes, with four couples in parallel and eight in series. The TE cell is the smallest power-producing component and is the basic building block of the power conversion subsystem.

The PCA is supported within a support frame that pins the hot- and cold-side heat exchangers together at a central location and supports the connecting manifolds. All externally applied thermal deformations are resisted by the support frame, while deformations within a TCA are accommodated by the compliant pads. 
Each of the 12 radiator assemblies is constructed of an array of varying lengths of potassium heat pipes brazed to a lithium duct/strongback structure at the center. The physical one-sided area of the radiator is $106.4 \mathrm{~m}^{2}$ $\left(1.1 \times 10^{3} \mathrm{ft}^{2}\right)$. The center spine carries adjacent lithium supply and return ducts that function to transfer heat to the attached heat pipe evaporator sections. The beryllium also functions as a strongback providing structural integrity for the panel in its launch-stowed configuration and as a bumper to protect the ducting from puncture due to micrometeroids or space debris.

The radiator heat pipe is a tube that encapsulates the titanium foil wick and potassium working fluid. The foil wick provides good capillary action and the titanium-beryllium tube provides a good conductive medium from the inside of the pipe to the high emissivity coated surface for radiation to space.

Each radiator panel has two flexible joints for the supply and return duct. The joints will be void of lithium in the frozen state so that the radiator can be deployed prior to reactor startup. Accumulators within the heat rejection subsystem accommodate the variable volume necessary to compensate for expansion and contraction of the lithium coolant. The accumulators will be fabricated from titanium.

The power conditioning, control, and distribution (PCC\&D) subsystem provides main bus regulated power and secondary bus power to the user plane electrical interfaces. It also provides command and control of the power system as well as transmits status and telemetry to the user. A modular shunt voltage regulator controls the main bus voltage by maintaining the electrical load on the thermoelectric converters at the design point with a controlled resistive load. The shunted power is radiated to space by a high-temperature dissipator. The modular design allows reconfiguration of the shunt regulators and bus control unit in response to mission changes and any degradation in orbit.

The mechanical/structural subsystem provides mechanical and structural integration of components as well as maintains thermal control. The primary structure for the power system consists of a series of structural rings interconnected with support trusses. To meet stiffness requirements, beryllium is 
used for the tube material and titanium-silicon-carbon metal matrix is used in highly stressed areas. The truss tube members are configured with standard lug/clevis fittings. The mechanical system is required to retain deployable components such as the boom, user interface module, and radiator during launch. It must then deploy the boom and radiator upon command while establishing in-orbit configuration and maintain correct spacecraft mechanical configuration for all mission phases. Thermal control is required to maintain thaw cavity integrity using multilayer insulation and electronics at standard temperatures. 


\subsection{DESCRIPTION OF PROPOSED TEST SITE ACTION}

\subsubsection{Test Reactor System}

The nuclear subsystem or assembly to be tested consists of the SP-100 reactor, the instrumentation and controls, the primary heat transport loop, and the radiation shield subsystem. The reactor controls and instrumentation and the primary heat transport loop used in the ground test will be as prototypic of orbiting space subsystems as is practical. The reactor, reflector panels, prototypic flight shield, and control drive mechanisms shown in Figure 3.1 comprise the portion of the nuclear subsystem discussed in Section 2.3 that will be typical of the space system.

Components included in the nuclear test facility to allow simulation of the space environment are the vacuum vessel and vacuum pumps, the EM pumps for moving coolant, and the cooling systems. The vacuum system will provide a pressure of $1.3 \times 10^{-15} \mathrm{~Pa}\left(10^{-8}\right.$ Torr $)$. The EM pumps will be capable of simulating TEM pump flows over ranges important for spacecraft operation. The vacuum vessel will be cooled to an average temperature of $350 \mathrm{~K}\left(170^{\circ} \mathrm{F}\right)$ to approximate radiant heat losses from the reactor and the primary heat transport loop encountered in space.

A redundant residual heat removal path will be provided by using the Auxiliary Cooling System (ACS), which is designed to ensure decay heat removal upon a total loss of normal cooling. The ACS is provided with totally separate piping, an EM pump, a surge tank, and a radiator panel. The in-reactor portion of this system is identical to that planned for space use and will allow testing to demonstrate integrated nuclear subsystem performance and interface capability. 


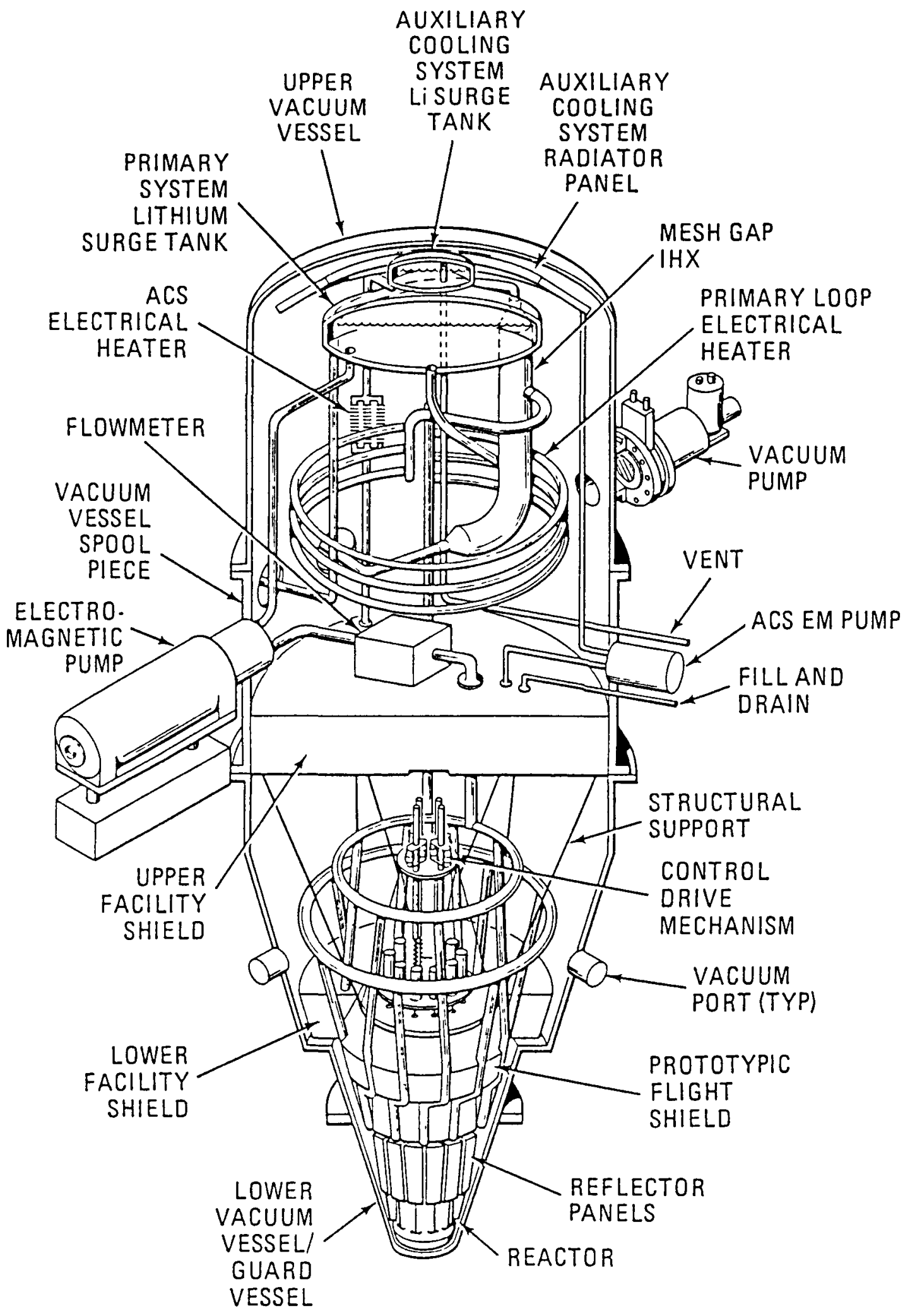

FIGURE 3.1. Test Reactor System. 


\subsubsection{Test Facility Operations}

\subsubsection{Overview of Program and Test Site Schedule}

Definitive design is currently in progress as is the supporting Safety Analysis. Significant milestones are as follows:

- Complete Proposed Test Site Selection

- Complete Definitive Design

- Complete Facility Qualification Testing

- Initiate Reactor Testing

- $\quad$ Complete Reactor Testing

- Complete Site Cleanup.
$11 / 21 / 85$

$10 / 31 / 90$

$12 / 30 / 91$

$1 / 1 / 92$

$12 / 31 / 92$

$10 / 31 / 94$.

\subsubsection{Facility Qualification Testing Program}

The SP-100 GES will be located in the 309 Building, an existing facility, which will be modified to meet DOE reactor operation criteria. A rigorous facility qualification testing program will be conducted using written procedures, which will be developed after modification but prior to installation of the SP-100 GES reactor. The facility qualification program will encompass testing of both components and systems.

Testing will be conducted by qualified technicians and test engineering personnel. Systems and components to be tested include:

- Electrical Power Systems

- Electrical Distribution

- Communications

- Fire Detection and Protection

- Heating and Ventilation

- Containment Isolation 
- Cooling Water

- Compressed Air

- Inert Gas

- Vacuum Vessel and Pumping

- Vacuum Vessel Cooling

- Radiation Monitoring

- Trace Heating.

No environmental releases are projected during the facility qualification testing program.

\subsubsection{Reactor Installation and Testing}

After facility qualification testing, the reactor will arrive on site and be fueled in the 309 Building containment structure. The vacuum vesse 1 will be closed and support system connections completed. An Integrated Leak Rate Test (ILRT) will be performed on the containment vessel prior to reactor testing. Startup testing will include:

- Lithium Fill of Primary Heat Transport System

- Sodium Fill of Secondary Heat Transport System

- Fill of Lower Vacuum Vessel Cold Wall Loop

- Vacuum Vessel Bàkeout

- Natural Circulation Performance

- Testing of Residual Heat Removal System

- Physics Characteristics

- Reactor Control and Safety Systems

- Ascent to $100 \%$ Power.

When startup testing has been successfully completed, the reactor will be operated for at least 3 mo and up to $2 \mathrm{yr}$ at full-rated power levels for performance testing. This testing period will include startup, shutdown, and transient testing. 
Reactor startup testing will be performed by qualified reactor operators with technical direction provided by test engineering and systems contractor personnel. All testing will be conducted using written procedures, which will be developed during the definitive design. Potential environmental releases during this phase of the life cycle for this project are addressed in Section 5.0 .

\subsubsection{Reactor Handling Following Testing}

Following full-power reactor performance testing, the reactor will be allowed to cool for 6 to 12 mo to reduce decay heat generation. The lithium coolant will then be drained from the reactor and the Primary Heat Transport System. The residual lithium, which has been enriched in the concentration of the isotope lithium-7. The residual lithium, which has been enriched in the concentration of the isotope 1 ithium-7, will be reacted to form a salt and disposed of as mixed waste. Since draining of the lithium coolant cannot entirely remove all lithium from the system, a liquid anhydrous ammonia cleaning of the reactor, fuel, and Primary Heat Transport System will be performed.

Anhydrous ammonia was chosen as a cleaning solvent, in part because it is a commonly used industrial and agricultural chemical with minimal environmental implications when released. The ammonia-lithium solution resulting from the reactor cleaning will be boiled off at a controlled rate to ensure no hazard to operations personnel and no environmental impact (anhydrous ammonia boils at $-33^{\circ} \mathrm{C}$ ). The residual lithium will be reacted to form a salt and disposed of as mixed waste.

The plan is to disassemble and inspect (as programmatically required) the reactor and evaluate its condition after nuclear testing. Therefore, the capability for disassembly and inspection (as well as repair and maintenance procedures, if needed) will be available in the 309 Building. Further detailed inspection, if required, will be performed in existing Hanford hot cell facilities currently used for such activities. 


\subsubsection{Decontamination and Decommissioning}

It is anticipated that, following the SP-100 GES Test program, the 309 Building will be decontaminated and used for other programs. When it has been determined that the 309 Building $c$ an no longer serve research needs, the building will be decommissioned. Alternatives for the postoperation decontamination and decommissioning are under consideration. Once an alternative has been proposed, the appropriate environmental review will be conducted. The installation and operation of the SP-100 GES Test will increase the overall cost and effort of ultimately decommissioning the 309 Building by $\$ 4$ to $\$ 6$ million.

Following removal from the 309 facility, the SP-100 GES reactor assemblies may be subjected to nondestructive and destructive examination. Structural materials, such as the reactor vessel, will be separately disposed of as low-level waste at Hanford. Core components will be placed in containers meeting current federal transportation and high-level radioactive waste packaging standards (see Section 7.9). Because the core will not be operated long enough for the fuel to be fully depleted, and because the fuel is highly enriched uranium, disposal of the fuel will most likely be accomplished by recovery of the uranium via reprocessing. The fuel will be stored in approved containers until reprocessing or final disposal is performed. A candidate facility for reprocessing of the core is the Idaho Chemical Processing Plant. If the fuel cannot be recycled, the fuel will be handled as transuranic waste and ultimately disposed of using the Waste Isolation Pilot Plant (WIPP).

\subsubsection{Test Site Description}

The GES Test Site Facility, to be located within an existing reactor containment vessel in the Hanford 300 Area (309 Building), will provide a location for the safe and reliable operation of an 2.5-MWt* fast flux nuclear reactor in an environment closely simulating outer space vacuum and temperature conditions. (See Figure 3.2.). The facility shall also provide for safe

\footnotetext{
*The test facility is being designed for a 2.5-MWt system. This will accommodate the 2.4-MWt nuclear assembly.
} 


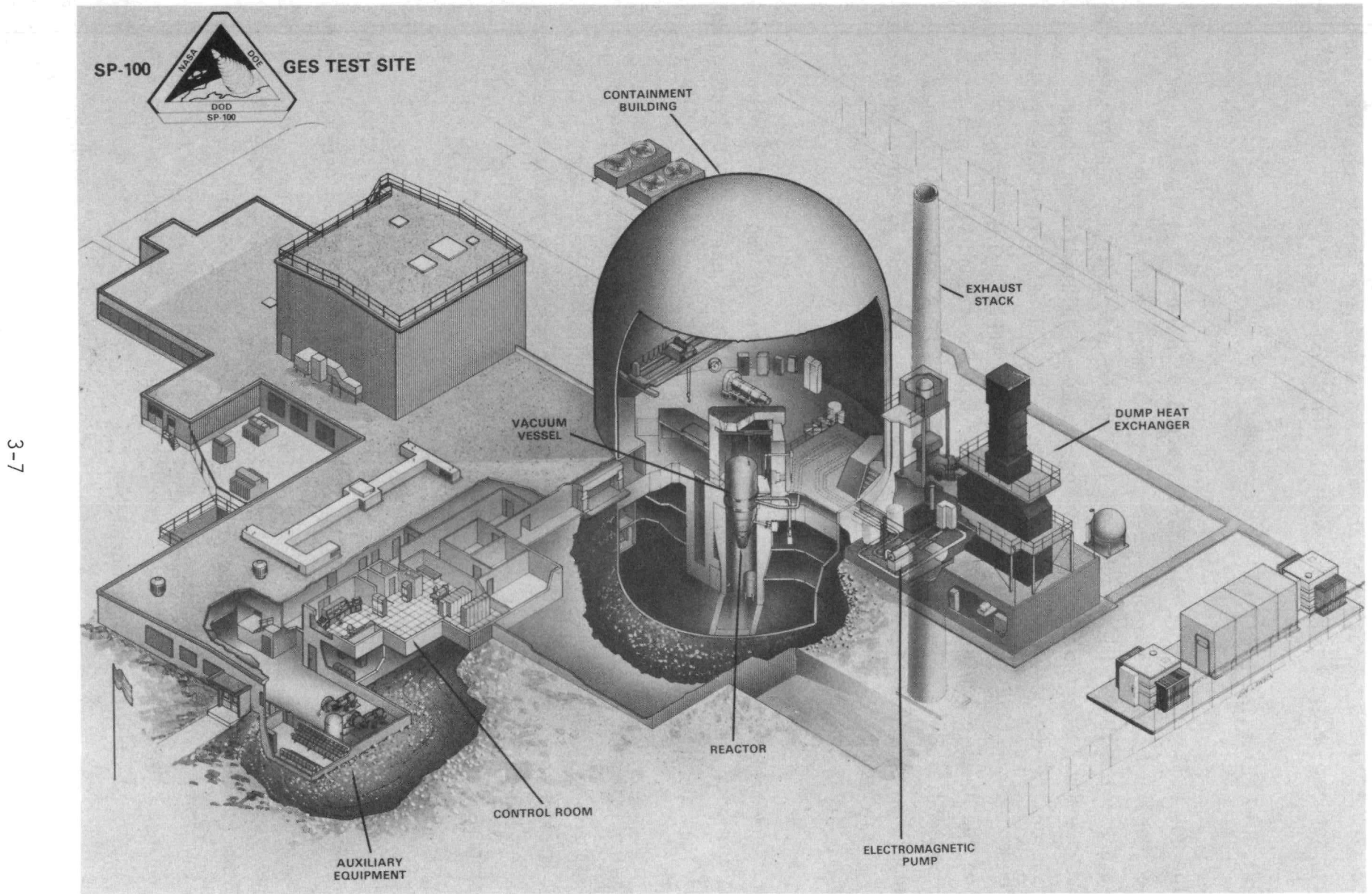

FIGURE 3.2. SP-100 GES Preliminary Equipment Arrangement in the Hanford Site 309 Building. 
construction and operation of the associated primary heat transport, vacuum, and support (e.g., heating and ventilation) systems.

\subsubsection{Existing Facility}

The 309 Building facility was first occupied in 1960. It was originally designed and built as a high-pressure containment for the pressurized, water-cooled 70-MWt Plutonium Recycle Test Reactor (PRTR). The PRTR mission was the development of technology for the use of plutonium in power reactors. The reactor was shut down in 1969. All PRTR fuel was removed. The containment vessel above ground level was made into a clean room shop, and the below-grade areas were monitored and maintained to support clean room conditions. Since decommissioning of the PRTR, the facility has undergone many modifications for new uses. It has most recently been used for computer systems maintenance and repairs and for glovebox fabrication and modification.

The 309 Building, as it currently exists, consists of two main parts: the containment vessel (with below-grade cells) and the services, utilities, and offices sections (see Figures 3.3 and 3.4 ).

The containment vessel is an all-welded steel cylinder $24.2 \mathrm{~m}$ (80 ft) in diameter with a hemispherical dome and a hemiellipsoidal bottom. It is $31 \mathrm{~m}$ (121 ft $6 \mathrm{in.)}$ tal1, extending $22.5 \mathrm{~m}(75 \mathrm{ft}$ ) above grade. The internal design pressure of the vessel is $200 \mathrm{kPa}(15 \mathrm{psig})$, and the design maximum external pressure is $105 \mathrm{kPa}(0.58 \mathrm{psig})$.

The containment vessel above the reactor hall floor is protected from missiles by a 1-ft thick concrete cylindrical wall that extends $210 \mathrm{~m}$ (33 ft) above grade. This structure also supports the rails for the overhead crane.

The exterior surface of the containment shell above grade is covered with $76 \mathrm{~mm}$ ( $3 \mathrm{in.}$ ) of insulation over which a waterproof membrane is applied. Below grade, the exterior surface of the vertical cylinder is protected with $6.35 \mathrm{~mm}(0.25 \mathrm{in}$.) of waterproof membrane and the bottom with $3.47 \mathrm{~mm}$ ( 0.15 in.) of waterproof membrane. 


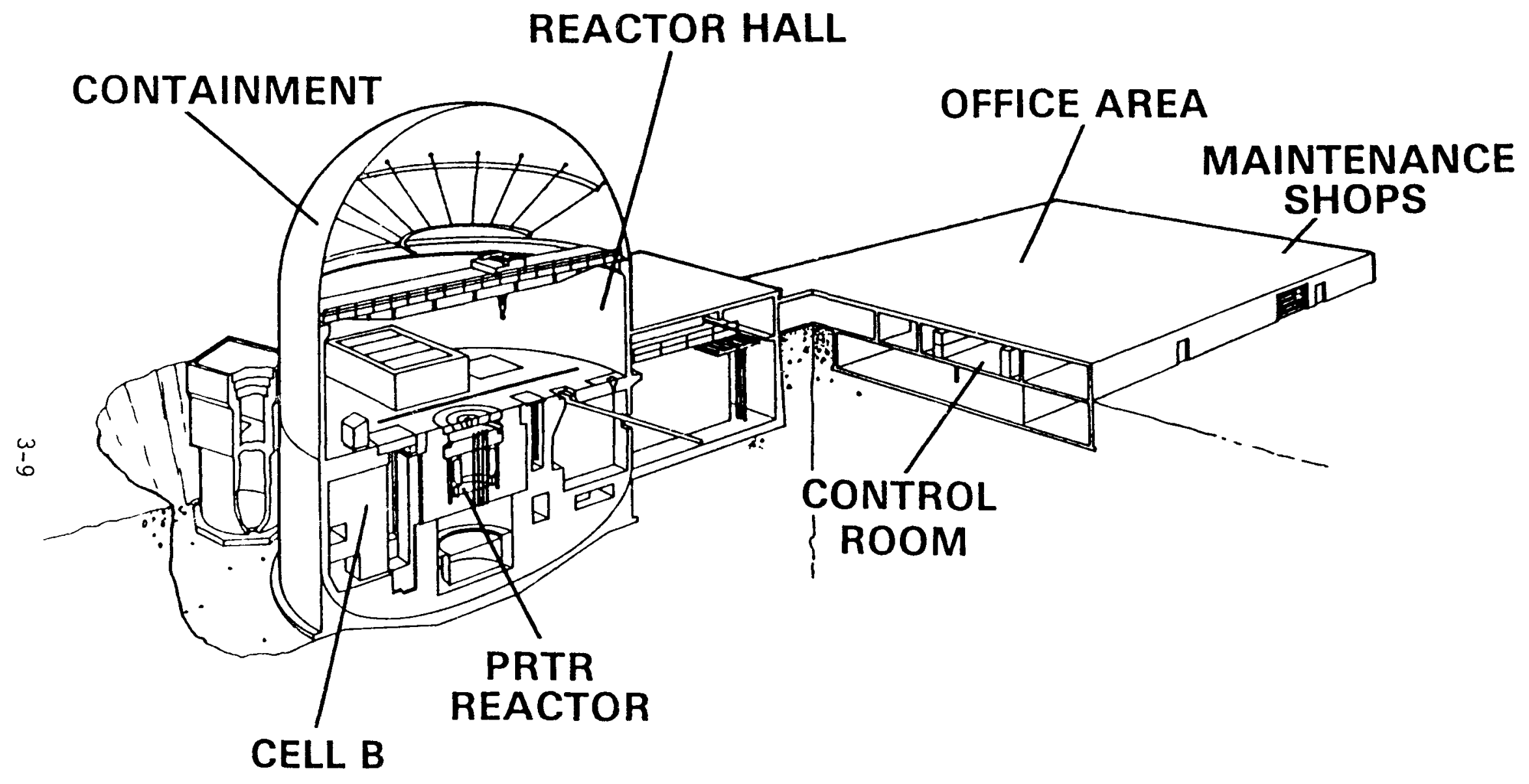

HEDL

FIGURE 3.3. GES Test Reactor Facility (309 Building). 
$\stackrel{\omega}{\frac{1}{0}}$

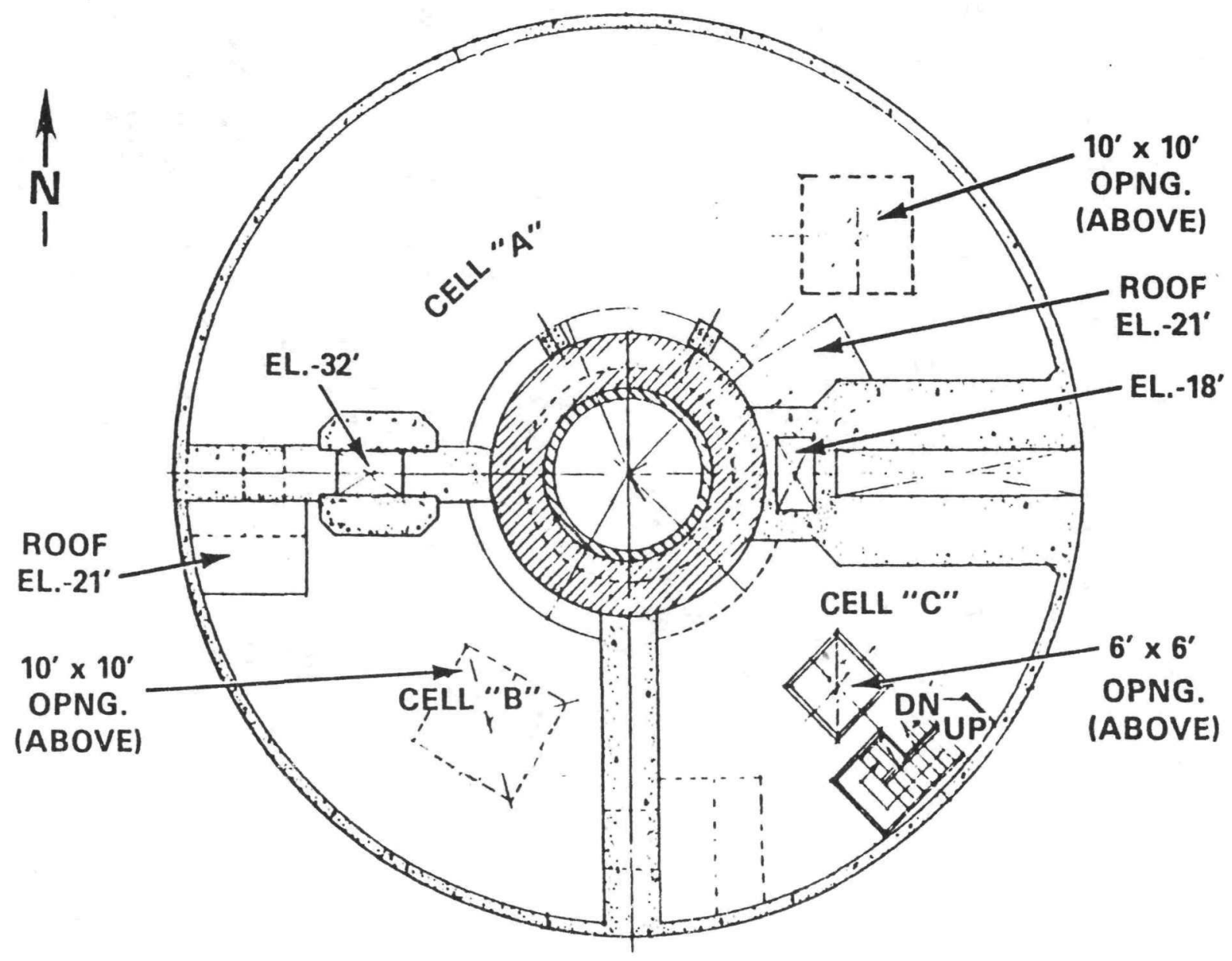

HEDL 8603-090.2

FIGURE 3.4. SP-100 GES Process Cells (Below Grade). (This figure shows the current facility layout.) 
A personnel airlock allows a ground-level environmentally controlled access to the reactor hall from the service area. It is $23.1 \mathrm{~m}$ (10 ft) in diameter and $4.6 \mathrm{~m}(15 \mathrm{ft})$ long. The doors are $1.2 \mathrm{~m}(4 \mathrm{ft})$ wide by $2.4 \mathrm{~m}(8 \mathrm{ft})$ high and have mechanical airseal interlocks and indicating lights. These ensure that both doors cannot be opened simultaneously during reactor operation. Emergency exit (directly outside) can occur through an additional groundlevel airlock that is $1.5 \mathrm{~m}(5 \mathrm{ft})$ in diameter and $2.1 \mathrm{~m}(7 \mathrm{ft})$ long with $0.9-\mathrm{m}$ (3-ft) diameter doors. This airlock also has interlocks to prevent opening both doors at the same time.

An equipment door, which is $4.0 \mathrm{~m}(12 \mathrm{ft})$ wide and $4.9 \mathrm{~m}(16 \mathrm{ft}) \mathrm{high}$, opens directly to the outside from the containment operating floor. This door, a modification to the containment, was added after the PRTR was shut down. It makes possible large equipment access. It will be replaced with a qualified sealed hatch or welded patch prior to SP-100 reactor operation.

The decommissioned PRTR reactor vessel is located in the central reactor cavity in the below-grade portion of the containment vessel (see Figures 3.2 and 3.4). The PRTR vessel is surrounded by a thick, cylindrical shielding wall, which is also common to each of the three process cells. The three cells are also divided by $1.5-\mathrm{m}(5-\mathrm{ft})$ thick, radial, concrete shielding walls.

The three below-grade cells (see Figure 3.4 ) were formerly designated:

- Process Equipment Cell (Cell A)

- Experimental Equipment Cell (Cell B)

- Instrument and Hot Shop Cell (Cell C).

Ce11 C contains three levels; on the $-11-\mathrm{ft}$ and $-21-\mathrm{ft}$ landings are instrument rooms and at the lower $(-34-f t)$ level is the hot shop. Cell $C$ is accessed from the reactor hall by stairs that first go through the instrument landings. From Cell C, access to Cell B is through a doorway in the radial shielding wall. Cell A can also be accessed from Cell C. Cells A 
and $B$ have covered openings at the top directly into the reactor hall. These allow crane access for transporting items into the cells. Cell C and both instrument rooms have similar openings to allow crane access to all three landings. The openings on top of Cells $A$ and $B$ are covered with shielded, stepped blocks to shield against radiation and prevent radiation streaming.

Outside the containment vessel, the 309 Building includes offices, lunchrooms, computer and computer repair facilities, a storage basin area (which is now used for offices), and a basement area that contains chilled water equipment, compressed air equipment, electrical switchgear, and a battery room.

The 309 Building framework (outside containment) is welded corrugated steel. The roof is a steel deck with a 20-yr built-up tar and gravel finish. The floor is concrete covered with vinyl tile.

Separate heating and ventilation systems are provided for the containment vessel and the remainder of the 309 Building.

Heating and ventilation for the containment vessel is provided by fan units equipped with electric heating elements and chilled water coils. Chilled water is supplied by three 60-ton water chillers. A 5000-cfm supply unit complete with heating coils, filters, and spray chambers provides general heating and ventilation. The heating and ventilation exhaust fan is housed in the exhaust fan pit with exhaust to the 45.7-m (150-ft) stack east of the fan pit. Two stages of high-efficiency particulate air (HEPA) filters are available prior to exhausting (see Figure 3.5).

The 309 Building is equipped with normal electrical power. It also has process and sanitary sewer lines. No radioactive liquid waste system is currently used in the 309 Building. 


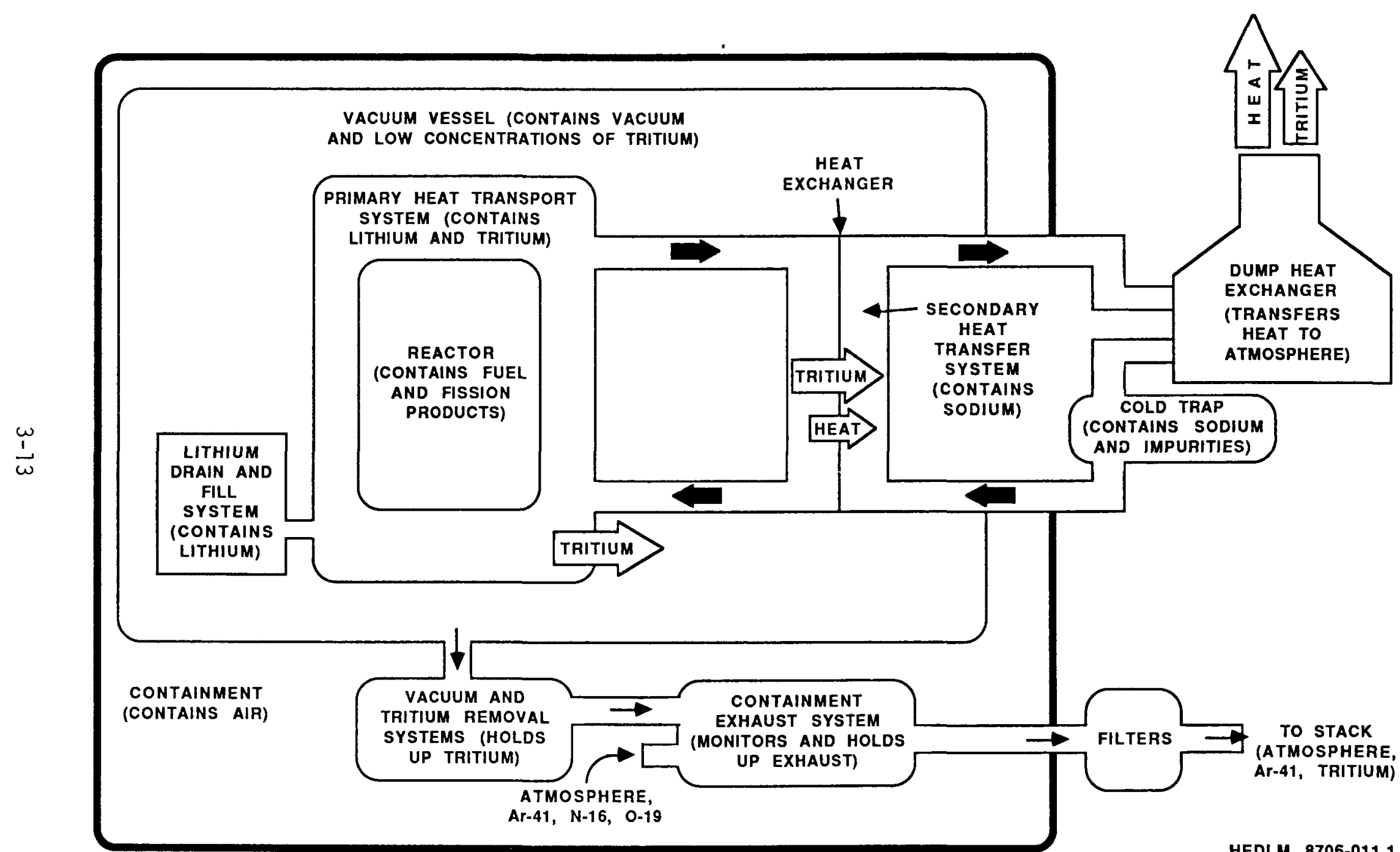

FIGURE 3.5. SP-100 System Overview. 
The 309 Building was designed and constructed in accordance with the Uniform Building Code $(U B C)^{(3.1)}$ applicable when constructed. The UBC requires that structures be built to withstand natural force loadings (such as those from wind and earthquakes) expected at Hanford. Thus, the UBC requires resistance to seismic activity of an intensity of VII on the Modified Mercalli (MM) scale. This is commensurate with a seismic Zone II area. Those portions that will be required to perform safety functions (e.g., containment) will be analyzed and tested to determine compliance with current standards and upgraded as necessary to meet current standards for Design Basis Earthquakes (DBE). Construction would be limited to modification of the existing facility, addition of dump heat exchanger (DHX) support structures, an electrical substation, and support pads for chillers.

\subsubsection{Secondary Heat Transport System}

The Secondary Heat Transport System provides for the ultimate rejection of the reactor heat to ambient air using sodium as the heat transfer medium. Heat is removed by using a heat transport circuit, with ultimate heat rejection to the atmosphere by a sodium-to-air dry DHX (see Figures 3.3, 3.6 , and 3.7 ).

The reactor heat is transferred from the Primary Heat Transport System lithium into the all stainless steel (type 316) Secondary Heat Transport System through the intermediate heat exchanger (IHX) located in the vacuum vessel.

The Secondary Heat Transport System loop consists of the shell side of the IHX, one or two EM pumps, an EM flow meter, miscellaneous valves and connecting pipes, and a forced-air DHX. Expansion and contraction of the sodium over the operating temperature range is accommodated automatically by a surge tank (with no feed or bleed of sodium for volume adjustment). The approximate volume of the Secondary Heat Transport System loop is 900 gallons. 


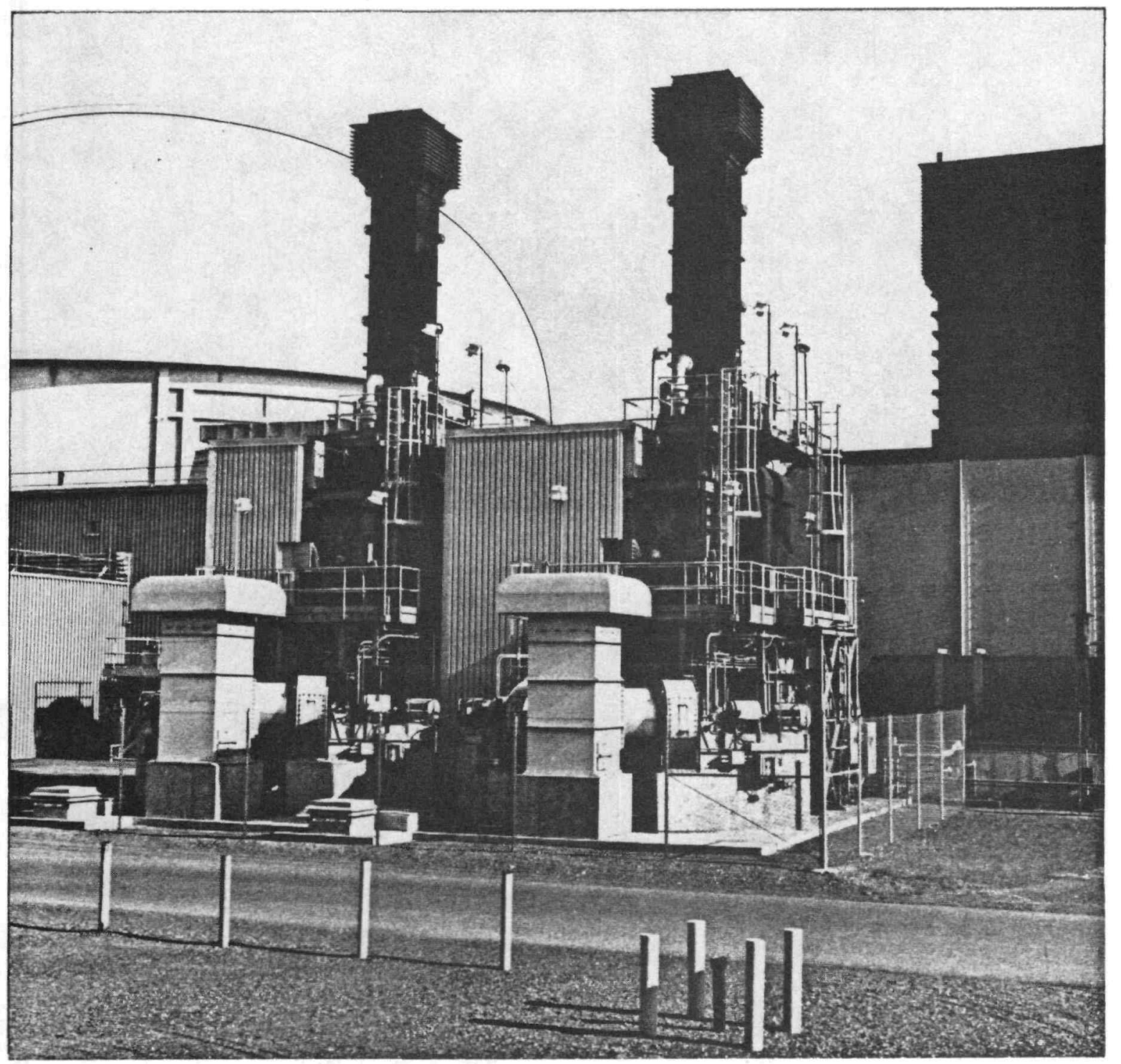

HEDL 8603-129.27

FIGURE 3.6. Existing Unused FFTF Closed Loop Dump Heat Exchangers. One Will Be Used for SP-100 GES Test Heat Rejection. 


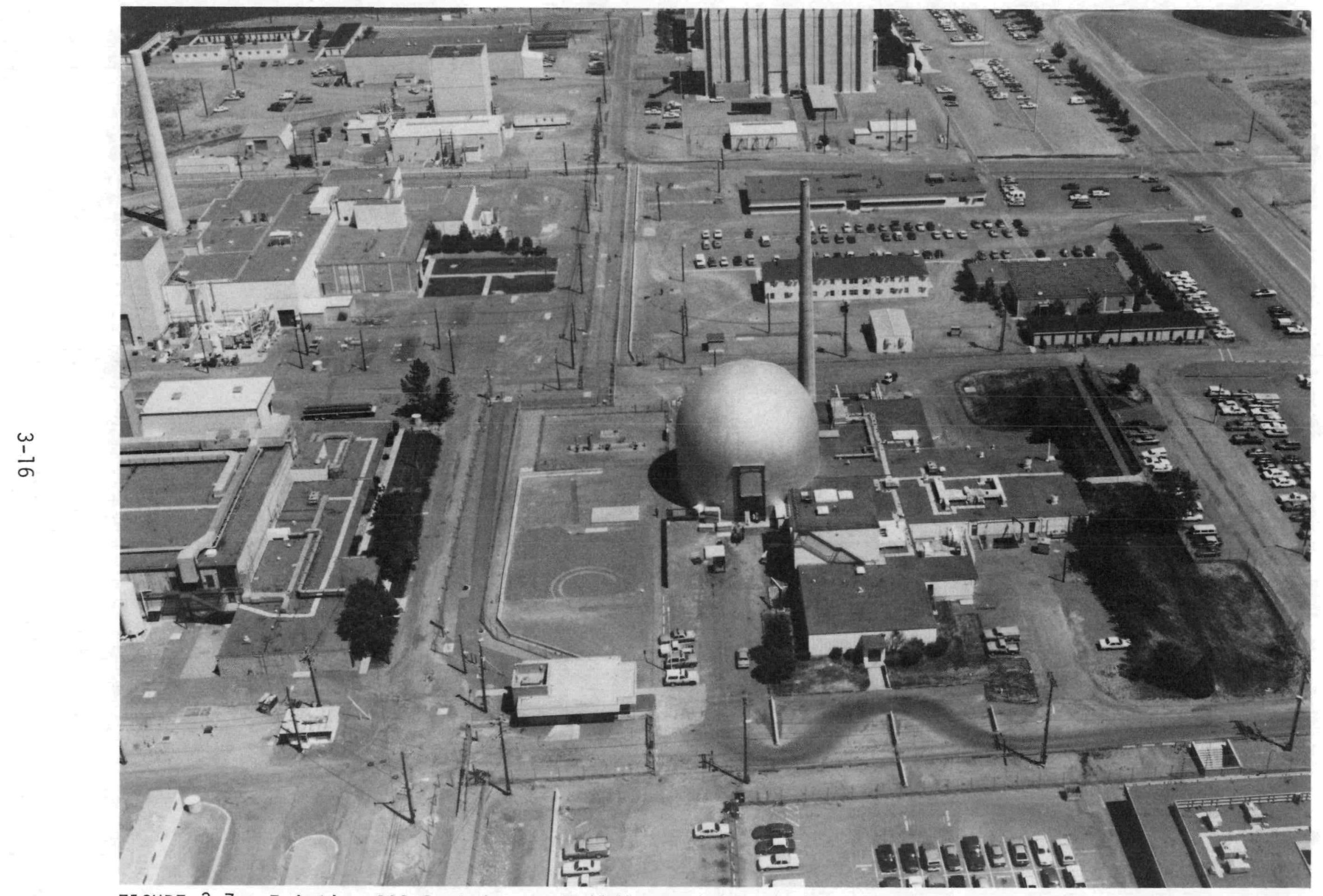

FIGURE 3.7. Existing 309 Containment Building and Attached Structures. 
Argon cover gas blanketing the sodium in the surge tank is designed to maintain a higher sodium pressure on the secondary side of the IHX than that of the primary lithium side for all normal and off-normal operating conditions.

Sodium chemistry is maintained within specifications by circulating a small percentage of the coolant through an air-cooled cold trap and a heated hot trap. Impurities will precipitate out in the cold trap or be removed by the hot trap. The impurity levels in the sodium are monitored by a multipurpose sampler and an on-line plugging temperature indicator. The plant design includes radiation shielding to reduce the potential neutron activation of the secondary sodium in the IHX to low levels consistent with hands-on maintenance access. A small percentage of the tritium generated in the Primary Heat Transport System by neutron bombardment of the lithium diffuses to the Secondary Heat Transport System. The majority of this tritium is collected in the cold trap or remains in solution in the sodium; a small amount migrates through the Secondary Heat Transport System sodium boundary to the atmosphere. Environmental implications of releases and cold trap disposal are developed in Section 5.0.

The Heat Transport System is designed to remove reactor heat for all normal and off-normal events. The EM pumps and power supplies have coast-down characteristics that ensure that reactor temperatures following a reactor trip (rapid shutdown) are within acceptable limits. Cooling for the off-normal events that seriously impair the ability of the Primary Heat Transport System to transfer the reactor heat to the Secondary (e.g., a failure of the primary boundary) is provided by the Residual Heat Removal System. To protect against a complete loss of flow in the event of a loss of electrical power, the configurations of the Primary and Secondary Heat Transport Systems have been arranged to provide for natural-convective cooling for reactor decay heat. 


\subsubsection{Vacuum Vessel}

The SP-100 GES reactor, the prototype shield, and the Primary Heat Transport System will be housed in a vacuum vessel. The vacuum vessel will be a segmented right circular cylinder $10 \mathrm{ft}$ in diameter and will have an overall length of $\sim 25 \mathrm{ft}$. The vessel will be fabricated from 304 stainless steel in accordance with the ASME Boiler and Pressure Vessel Code. (3.2) The vacuum vessel will function as a safety class system to help mitigate the consequences from reactor design basis events. The vessel will be designed to maintain its integrity following the DBE.

The vacuum vessel will be supported at its midsection with an interfacing structure to the containment building concrete structures. The vessel will form a vacuum boundary that will allow evacuation to an ultra-high vacuum level. This vacuum level precludes the reaction of atmospheric and other gases with the refractory materials of the test article. The vacuum vesse 1 will also be temperature controlled to provide a heat sink for the radiative heat rejection from the test article.

\subsubsection{Containment Structure}

The existing containment vessel (Figure 3.7 ) is a pressure-tight, cylindrical, welded steel vessel $80 \mathrm{ft}$ in diameter and $121 \mathrm{ft}$ high and was designed, constructed, and tested in conformance with the ASME Boiler and Pressure Vessel Code, Section VIII, Division 1. (3.2) The bottom of the vessel is $\sim 46 \mathrm{ft}$ below grade and is supported on a reinforced concrete pad. Abovegrade penetrations through the containment vessel include the personnel airlock, emergency airlock, equipment transfer hard patch (12 ft $\times 16 \mathrm{ft}$ ), ducts for supply and exhaust ventilation, and penetrations for piping and wiring. All penetrations are leak-tight. The entire containment building and penetrations will be leak-tested periodically in accordance with ANSI/ANS Standard 56.8-1981, "Containment System Leakage Testing Requirements."(3.3) The design pressure of the vessel is 15 psig. 
The operating floor inside the containment vessel is at ground level. Most of the equipment, including the test reactor, will be located in below-grade cells. Some of these cells will be accessible during facility operation. All liquid metal heat transport equipment will be enclosed and provided with fire suppression systems in the event of a liquid metal leak. An air atmosphere is maintained in the space above the operating floor. Equipment in this space includes a gantry crane that services the area, heating and ventilating equipment, miscellaneous accessories, utilities, and control stations. This above-grade work area will be shielded from the reactor and primary coolant and will permit continuous occupancy during full-power operation.

The 309 Building is divided into ventilation control zones, balanced to cause airflow from areas of lesser contamination potential to areas of greater potential. The containment building is maintained at a slight negative pressure relative to the atmosphere so that normal leakage will be from outside to inside.

\subsubsection{Containment Isolation System}

To further minimize the impact from potential airborne radiation sources, exhaust ventilation air passes through HEPA filters prior to release to the atmosphere. Under normal operating conditions, the activity level of the exhaust ventilation air is expected to be essentially that of background.

The containment vessel design for leak-tightness and pressure containment provides additional protection in the event of a severe release of radioactivity due to accident conditions. Monitors are located in the exhaust ventilation system to provide for isolation of containment building ventilation in the event of abnormal radioactivity levels. The containment building is designed to leak no more than $0.1 \%$ per day at 15 psig internal pressure and at a peak temperature of $242^{\circ} \mathrm{F}$. This will provide the capability to safely accommodate the full range of hypothesized accident conditions (including radionuclide releases from the reactor and lithium or sodium spills and fires). 


\subsubsection{Process Gas Handling Systems}

\subsection{Vacuum System}

The Vacuum System for the SP-100 GES Test Site will produce the ultra-high vacuum level inside the vacuum vessel described earlier. The system operating level has been specified at $1.3 \times 10^{-9} \mathrm{~Pa}\left(1 \times 10^{-8}\right.$ Torr $)$ total pressure. This pressure level will be achieved by a three-part pumping system.

The rough vacuum pumping package consists of dual rotary vane pumps. These pumps will reduce system pressure from $101 \mathrm{~Pa}\left(760\right.$ Torr) to $1.3 \times 10^{-2} \mathrm{~Pa}$ $\left(1 \times 10^{-1}\right.$ Torr $)$. The roughing package also contains cryostats to prevent oil back-streaming from the pumps to the vacuum vessel. The roughing package can be isolated from the vacuum vessel by separate isolation valves. The next pumping stage, rough to high vacuum, is achieved by dual turbomolecular pumps. This pumping package will reduce the vacuum vessel pressure from $1.3 \times 10^{-2}$ to $1.3 \times 10^{-7} \mathrm{~Pa}\left(10^{-1}\right.$ to $10^{-6}$ Torr $)$. The turbomolecular pumps are connected to the vacuum vessel and are individually isolated by bakable vacuum valves.

The operating pressure of $1.3 \times 10^{-9} \mathrm{~Pa}\left(1 \times 10^{-8}\right.$ Torr $)$ is achieved in the vacuum vessel by multiple close-coupled cryopumps and ion pumps. Three cryopumps will be installed on or near the midsection of the vacuum vessel above the reactor shields.

These pumps will produce the operating vacuum level in the upper vessel section. Two additional cryogenic pumps and three ion pumps will be installed on the midsection of the vacuum vessel below the intermediate shield. These pumps will be connected to the vessel with a short section of large-diameter ducting to allow the placement of local shielding around the pumps. The local shielding will supplement primary reactor shielding to reduce the neutron radiation level at the pumps. All high-vacuum pumps are individually isolated from the vessel by vacuum valves. 


\subsection{Tritium Removal System}

Although lithium with reduced ${ }^{6} L i$ concentrations will be used in the Primary Heat Transport System, trace amounts of ${ }^{6} \mathrm{Li}$ will remain. The majority of the tritium produced by the neutron bombardment of $6_{\mathrm{Li}}$ will permeate through the pressure boundaries to the Vacuum System. The tritium in the Vacuum System will be initially collected in the vacuum pumps. As the operating cryopumps accumulate sufficient tritium, they will be isolated and allowed to warm sufficiently to drive off the tritium. The tritium will be passed to a Tritium Removal System by means of a vacuum pump. The tritium will be trapped in tritium absorption canisters and stored in the removable canisters. The canisters will be isolated and then removed and recycled.

The tritium that does not permeate to the Vacuum System or remain in solution in the primary lithium will permeate from the Primary Lithium System to the Secondary Sodium System. The tritium in the Secondary Sodium System will remain in solution in the sodium or be trapped out in the cold traps. A very minor amount of tritium (less than $0.03 \mathrm{mCi} / \mathrm{day}$ ) will permeate the secondary piping and be vented via the DHXs or to the containment heat transport cells. The cells in turn will allow the tritium to pass to the Containment Exhaust System where it will be released to the atmosphere through the vent stack. The amount of tritium released to the atmosphere will be well within limits established by DOE Order as well as Federal and state standards. (See Section 7.0 for limits and environmental consequences and Section 7.1 for a discussion of DOE requirements.)

\subsection{Containment Ventilation and Cell Atmosphere Control}

Containment air flow is maintained by a conditioned air supply of $5000 \mathrm{ft}^{3} / \mathrm{min}$, which enters the containment at a location above the stairway to Cell $\mathrm{C}$. The air flows down the stairwell and into Cell C. At this point, the flow splits and diverts into Cell $A$ and Cell B. A $6500 \mathrm{ft}^{3} /$ min exhaust blower receives air from Cells $A$ and $B$ and discharges it through a HEPA filter bank to the atmosphere through an exhaust stack. The containment is normally maintained at a negative pressure of $0.45 \mathrm{in}$. WG. 
Air circulation and temperature control are maintained by nine recirculation units located above the operating level and throughout each of the lower cells.

\subsection{Exhaust Monitoring System}

Exhaust monitoring capability will be upgraded to provide continuous monitoring and alarm of off-normal conditions. The equipment will be capable of detecting the full range of anticipated isotopes. Automatic isolation of the exhaust will occur if releases exceeding limits are detected. The system will be designed to meet or exceed the requirements of ANSI Standard N13.1-1969 (R1982), "Guide to Sampling Airborne Radioactive Materials in Nuclear Facilities." (3.4)

\subsection{Inert Gas Supply and Exhaust System}

Argon, nitrogen, and helium will be stored in dewars and bottles. Argon or nitrogen may be used as a cover gas for liquid metal systems and as a fire suppressor. Helium will be used to fill the vacuum chamber in the event of a loss of vacuum. Helium may also be used as a cover gas for the lithium liquid metal systems. Nitrogen may be used to flush helium from the vacuum vessel.

If argon is used as cover gas, it will become radioactive. Prior to release to the atmosphere, the radioactive argon will be stored until the activity has reached an acceptable level as established by DOE Order $5480.1 \mathrm{~A}^{(3.5)}$ as supplemented and by state radioactive emission regulations (see Sections 7.1 and 7.9). It will then be released out the stack.

The argon that is used for fire suppression in the event of a sodium fire will be discharged into the atmosphere through the Heating, Ventilation, and Air Conditioning (HVAC) system. Helium or nitrogen used to flood the vacuum vessel will be vented to the atmosphere after being treated by the tritium gettering traps. 
No environmental impact will result from discharge of helium, argon, or nitrogen.

\subsubsection{Test Article Handling System}

The SP-100 GES Test Article Handling System (Figure 3.8) provides those facilities and equipment necessary to install, remove, and disassemble the test article and dispose of and/or store its components, subassemblies, and parts after disassembly. The latter operations will be accomplished through a combination of remote-handling techniques and hands-on/long-handled tool methods. The equipment and tooling required for these tasks will be verified by mockup demonstrations prior to facility operation. As part of the disassembly and disposal operations, a method of shipment for radioactive components will be developed.

The removal operations will drain the lithium from the primary system upon completion of the test, remove the residual lithium from the interior surfaces, secure and separate the reactor from the remainder of the Primary Heat Transport System, and remove selected portions and/or the entire primary system.

The residual Lithium Removal System is a closed, recirculating loop using anhydrous liquid ammonia for the cleaning solution. The Lithium Removal System will be connected to the Test Article Primary System following drainage of the lithium but prior to cutting into the primary system. The liquid ammonia will be circulated in the primary system until the majority of the lithium has been dissolved.

The lithium/ammonia solution will then be drained and treated with alcohol to react the lithium to form lithium hydroxide. The lithium hydroxide will be reacted to form lithium salts and disposed of as mixed waste. An acid bath/scrubber will be used to neutralize the ammonia. Residual tritium released by this process will be captured by gettering systems. Section 5.1 provides discussion of the environmental consequences of this activity. 


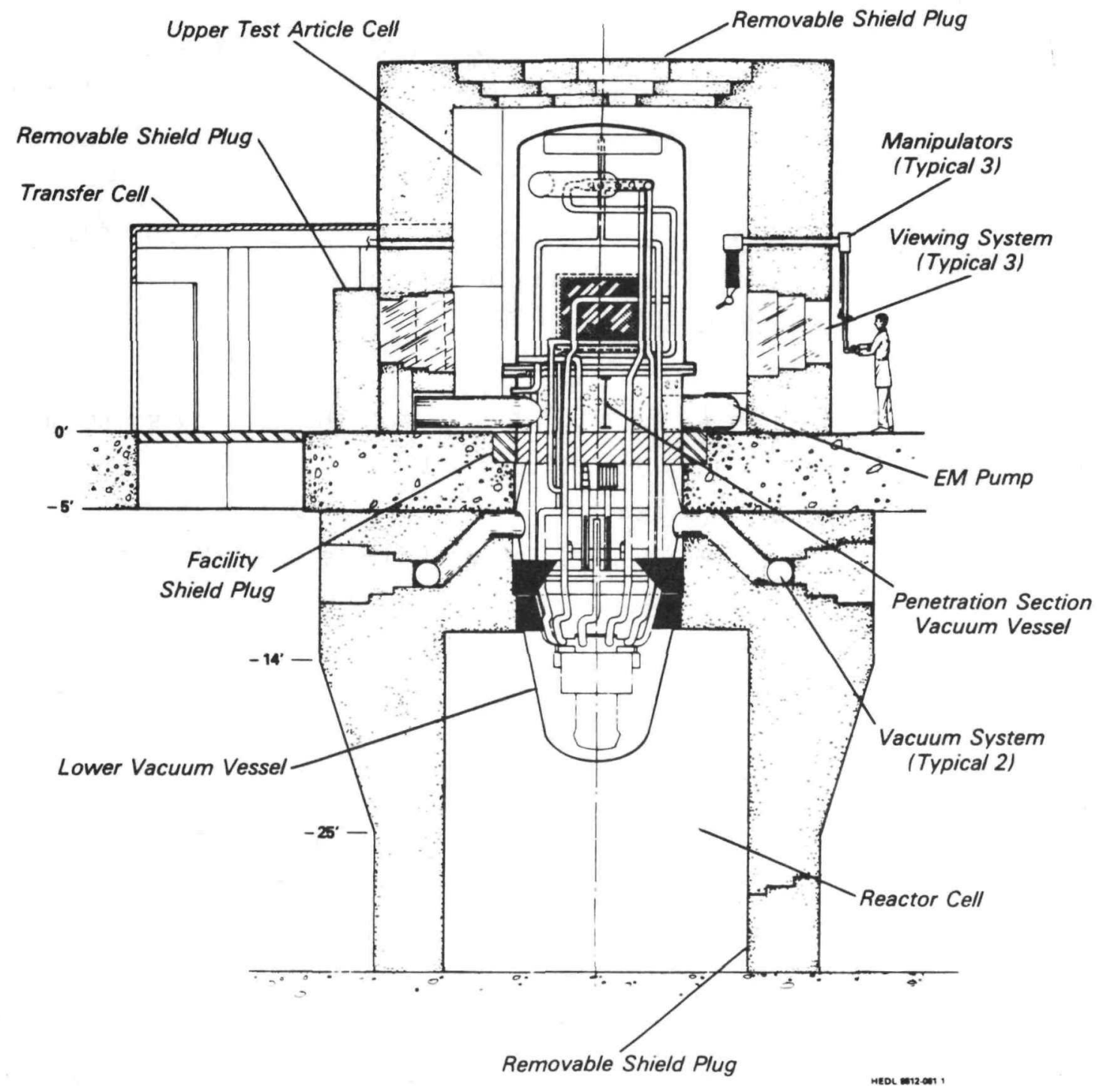

FIGURE 3.8. SP-100 GES Test Article Handling System. 
Dismantling the test article will directly support posttest examination and/or final disposal activities. Following dismantling operations, major components will be further disassembled into subcomponent units. At this time, key posttest examination specimens may be removed for dimensional, metallurgical, and mechanical measurements at other laboratory hot cell facilities. Casks qualified for shipment of the particular radioactive materials in accordance with DOE Order $5480.3^{(3.6)}$ will be used.

The capability for interim test article maintenance or failure recovery will be included in the work scope of the Test Article Handling System.

The test article will be disposed of after irradiation and post-test examination. If possible, the enriched fuel materials will be recycled using the Idaho Chemical Processing Plant. If this is not possible, the materials will be handled as transuranic (TRU) waste and ultimately disposed of using the Waste Isolation Pilot Plant. Activated structural materials will be disposed of as mixed waste at Hanford. The lithium coolant will be reacted to form a salt and disposed of as mixed waste. Further discussion of the environmental impacts of final test article disposal can be found in Section 5.0 .

\subsubsection{Primary Lithium Fill and Drain System}

The Lithium Fill and Drain System receives the fresh 1 ithium in drums, provides the capability for melting the frozen metal, and then circulates and purifies the lithium. When the required purity has been achieved, the lithium is ready for transfer into the Primary Heat Transport System and the Auxiliary Cooling System.

The Lithium Fill and Drain System consists of a drum unloading station, a filter, an electromagnetic circulating pump, a hot trap for removing impurities, and a storage vessel. The system operates with an inert cover gas at the free surfaces. The equipment will be mounted on a transportable pallet located on the reactor containment floor external to the test chamber. 
The hot trap is used for lithium purification and will include refractory metal foil, such as titanium or zirconium, to act as a getter for nitrogen and hydrogen. Lithium purification will only be performed when the reactor is not operating. Following the reactor test program, the hot trap will be removed and disposed of as hazardous waste. (See Section 5.0 for further discussion.)

The storage vessel will be used to receive the primary lithium when draining of the Primary Heat Transport System and the Auxiliary Cooling System is required.

\subsubsection{Control and Data Systems}

The SP-100 GES Test Facility has a variety of instrumentation and controls that provide three primary functions: Plant Protection, Facility Process Control, and Data Handling.

The Plant Protection System provides for automatic, safe reactor shutdown and containment isolation. This system measures coolant and component temperatures, primary and secondary coolant flow, neutron flux density from startup to full power, system pressure, sodium levels, gamma radiation, radioactive gases and particles, and other parameters of interest or necessity. Selected plant equipment is controlled by this system to ensure safe operation of the reactor test.

The microprocessor-based Facility Process Control System provides for both manual operation and automatic control of the reactor, the Heat Transport Systems, and auxiliary systems. It provides alarms for selected reactor and process parameters presented to the operator on a dedicated display screen.

Data Handling functions include acquisition at various sampling rates, calculations, archiving, and the capability for plotting time-histories and cross plots. This information can be presented in several forms, including cathode ray tube (CRT) displays and hard copy. 
Redundant sensors are provided, where necessary, to separate the plant protection and control functions.

\subsubsection{Safety Power Supply System}

A safety power supply system will be provided to permit functioning of structures, systems, and components important to safety. Sufficient capacity, capability, and redundancy will be provided to ensure that fuel parameters remain within design limits for anticipated operational occurrences, and that core cooling and containment integrity are maintained for all postulated accidents.

\subsubsection{Auxiliary Systems and Structures}

The SP-100 GES Test Site will use existing 300 Area systems and structures to the maximum extent possible. Where existing systems and structures do not meet the requirements, new systems or structures will be built.

The normal and alternate preferred power will be 13.8-kVA systems from the 300 Area Power Distribution System. Emergency power will also be supplied from the existing Hanford 300 Area diesel generator for protection of equipment.

The 300 Area Water System will supply cooling water and fire protection water. Waste water will be removed through the existing sanitary and process water systems.

Fire protection and other emergency services will be supplied by the 300 Area fire department.

The existing service wing of the 309 Building will be used to house the control rooms and will provide office space for the operating staff. Office space for the System Developer and other Westinghouse Hanford Company personnel will also be provided in the 309 Building.

The existing exhaust stack, roadway, and parking areas will be used. 
New structures will be required to support the DHX, and some new fencing will be required to meet security requirements.

\subsubsection{Construction}

Construction activities will be 1 imited to minor modification of the existing 309 Building and addition of internal systems such as the reactor. External construction will be limited to addition of DHX equipment, an electrical substation, and support pads for chillers (see Figure 4.4). Discussion of construction impacts can be found in Section 5.1 .

\subsection{ALTERNATIVES TO THE PROPOSED TEST SITE ACTION}

\subsubsection{Test Site Selection}

It was determined early in the SP-100 Program that a ground test of a prototypic flight unit would be necessary in order to evaluate the nuclear reactor performance and safety characteristics prior to use in space. A suitable test site with existing test facilities and support capability would be required for the test. Accordingly, a GES Test site selection process was initiated early in 1985, which coincided with the SP-100 space reactor power system design effort. The SP-100 Program Office appointed a Site Evaluation Committee (SEC) in March 1985 to direct the evaluation and selection process. A Technical Advisory Panel (TAP) was also appointed to support the SEC in the evaluation process.

The process of selecting,a preferred test site involved a series of steps summarized here. A more complete description of the evaluation and selection process is found in Appendix G. First, it was determined that, in order to reduce the overall cost of the test, only existing DOE facilities would be considered. A Site Selection Plan and a Facility Requirements Document were developed by the SEC to guide the selection process. Although most of the facility requirements were based on the functional needs of the ground test program, several of the requirements to be fulfilled by the site operator had environmental consequences. 
Following the development of the Facility Requirements Document a Request for Formal Proposal was then issued for interested sites. General descriptive information was requested as well as information on the approval process to be applied to the test program at the respective sites. Five interested DOE sites responded with proposals in May of 1985. The five sites responding with proposals were the Hanford Engineering Development Laboratory, Idaho Nuclear Engineering Laboratory, Nevada Test Site, Oak Ridge National Laboratory, and Sandia National Laboratories, Albuquerque.

The site evaluation process involved establishment of five evaluation criteria and assessment by the SEC and TAP of the submissions by each of the five sites. The site evaluation criteria included facilities and equipment, approval to operate, personnel and organization, integration with other activities and management commitment. Particular areas considered under the approval to operate criteria included cost, schedule, and site-specific environmental impacts.

Following the receipt of the site proposals, the SEC and the TAP made site visits as part of the site evaluation process. In addition, the TAP produced an analysis of the facility modifications and associated costs for each of the competing sites that was incorporated into the SEC evaluation.

In these evaluations, environmental factors were considered but did not constitute a major discriminating element. The use of existing facilities, with an emphasis on limited modifications for both cost and schedular reasons, suggested that construction impacts would be limited. The constrained nature of the test program and its duration, as well as the location of the test program activity in the midst of other ongoing operations, would imply a minimal incremental impact of the test program on current site operations. Nevertheless, these factors were an element in the evaluation process. The SEC reached a consensus listing of the strengths and weaknesses of each site with respect to the evaluation criteria and narrowed the preferred sites to the Hanford Engineering Development Laboratory and the Idaho Nuclear Engineering Laboratory. Recognizing that the environmental factors do not discriminate between the Hanford Engineering Development Laboratory and the 
Idaho Nuclear Engineering Laboratory, the Hanford Engineering Development Laboratory was selected as the preferred test site based on programmatic considerations such as cost, schedule, and risk.

\subsubsection{Hanford Alternatives to the Proposed Action}

A survey of potential sites at Hanford was conducted for the GES Test. The following Hanford facilities were evaluated:

$\begin{array}{ll}201 \mathrm{C} & \text { Hot Semi Works Plant in } 200 \text { East Area } \\ 202 \mathrm{~S} & \text { Redox in } 200 \text { West Area } \\ 221 \mathrm{~T} & \text { T-Plant in } 200 \text { West Area } \\ 221 \mathrm{U} & \text { U-Plant in } 200 \text { West Area } \\ 337 & \text { High-Temperature Sodium Facility (HTSF) in } 300 \text { Area } \\ 321 & \text { Hydromechanical Facility in } 300 \text { Area } \\ 309 & \text { PRTR Facility Containment in } 300 \text { Area } \\ 336 & \text { Sodium Test Facility in } 300 \text { Area } \\ 427 & \text { Fuel Cycle Plant in } 400 \text { Area } \\ 1706 \mathrm{~K} & \text { Building in } 100 \mathrm{~K} \text { East Area. }\end{array}$

The facilities were examined for suitability based on operational, safety, safeguards, and environmental characteristics. The operational factors included space, crane capacity, available auxiliary test space, supporting systems, extent of modifications needed, impact on existing programs, transportation, cost to install and operate, and postirradiation examination logistics. The safety, environmental, and test site characteristics included remoteness from population centers, availability of civilian regional emergency plans, physical characteristics of containment and shielding around the reactor test stand (including pressure, thermal, and nuclear capabilities), previous accident record, overall safety experience, size and load-carrying capability of the containment building, site characterization (seismic and tornadic), available environmental simulation, transportation (including proximity to assembly, maintenance, disassembly, and examination areas), heat rejection capability, and waste-handling capabilities (including availability of suitable disposal sites). 
The 309 Building was selected as the best Hanford facility for this purpose based on the existing containment building, the ease with which the facility can be upgraded to meet current environmental and safety standards, and the overall availability to support program objectives. All other facilities would have required reactor operation using confinement rather than containment. None of the other 300 Area facilities was designed as a reactor facility; upgrading them would have been substantially more expensive. This facility was recommended as the preferred site for the multisite review discussed in Section 3.2.1.

\subsubsection{Pursue a No-Action Course (i.e., Do Not Ground-Test the SP-100 Reactor)}

This alternative would not provide for ground testing of the SP-100 prototypic flight reactor and associated systems. Onsite environmental effects would not exist; the programmatic impact would be development of a flight system with inadequate ground-based verification of operational and safety functions.

Tests related to safe, environmentally sound, flight system operation will be performed. The ground testing of the SP-100 reactor subsystem will aid in verifying the performance, lifetime, and reliability of the reactor flight system design. Calculations concerning reactor neutronic performance need to be confirmed by testing. Overall programmatic safety-related decisions will be based on the data acquired during ground testing. Safe space operability of the system is jeopardized if earth-based testing of the reactor subsystem is not performed. 
This chapter describes the environmental characteristics of the Hanford Site that would be affected by construction and operation of the Ground Engineering System (GES) Test Site. The Hanford Site has been extensively characterized. Additional information on the Hanford Site environment is available in References 4.1 through 4.7, which are listed in Section 10.0.

\section{$4.1 \quad$ HANFORD SITE}

4.1.1 Site Location and Regional Population

The GES Test systems will be located in the 309 Building in the 300 Area of the Hanford Site. Hanford Site access is limited for national security, health, and safety reasons.

The Hanford Site occupies $21450 \mathrm{~km}^{2}\left(\sim 560 \mathrm{mi}^{2}\right)$ of a shrub-steppe in southeastern Washington (see Figures 4.1 and 4.2). Figure 4.2 shows the facilities on, and the land use of, the Hanford Site. Activities on the Site include standby operation of a dual-purpose plutonium production/power reactor in the 100N Area, operations of the Fast Flux Test Facility (FFTF) reactor in the 400 Area, and operation of the Washington Public Power Supply System (WPPSS) Nuclear Plant No. 2. Other activities include fuel reprocessing, waste management, fuel fabrication, laboratory operations, and ecological studies.

The 300 Area occupies $21.6 \mathrm{~km}^{2}\left(\sim 0.6 \mathrm{mi}^{2}\right.$ ) (see Figure 4.3 ). It is located within the southeast corner of the Hanford Site. It is bounded by the Columbia River on the east and by the Hanford Highway Route 4 South (Stevens Drive extended) on the west. The Hanford Site southern boundary is $\sim 1.7 \mathrm{~km}$ ( $1.1 \mathrm{mi})$ north of the Richland city limits and about $11 \mathrm{~km}(8.8 \mathrm{mi})$ north of the city center. The nearest residence to the 300 Area is $\sim 1.5 \mathrm{~km}$ ( $0.9 \mathrm{mi}$ ) east across the Columbia River. A number of farms are located 


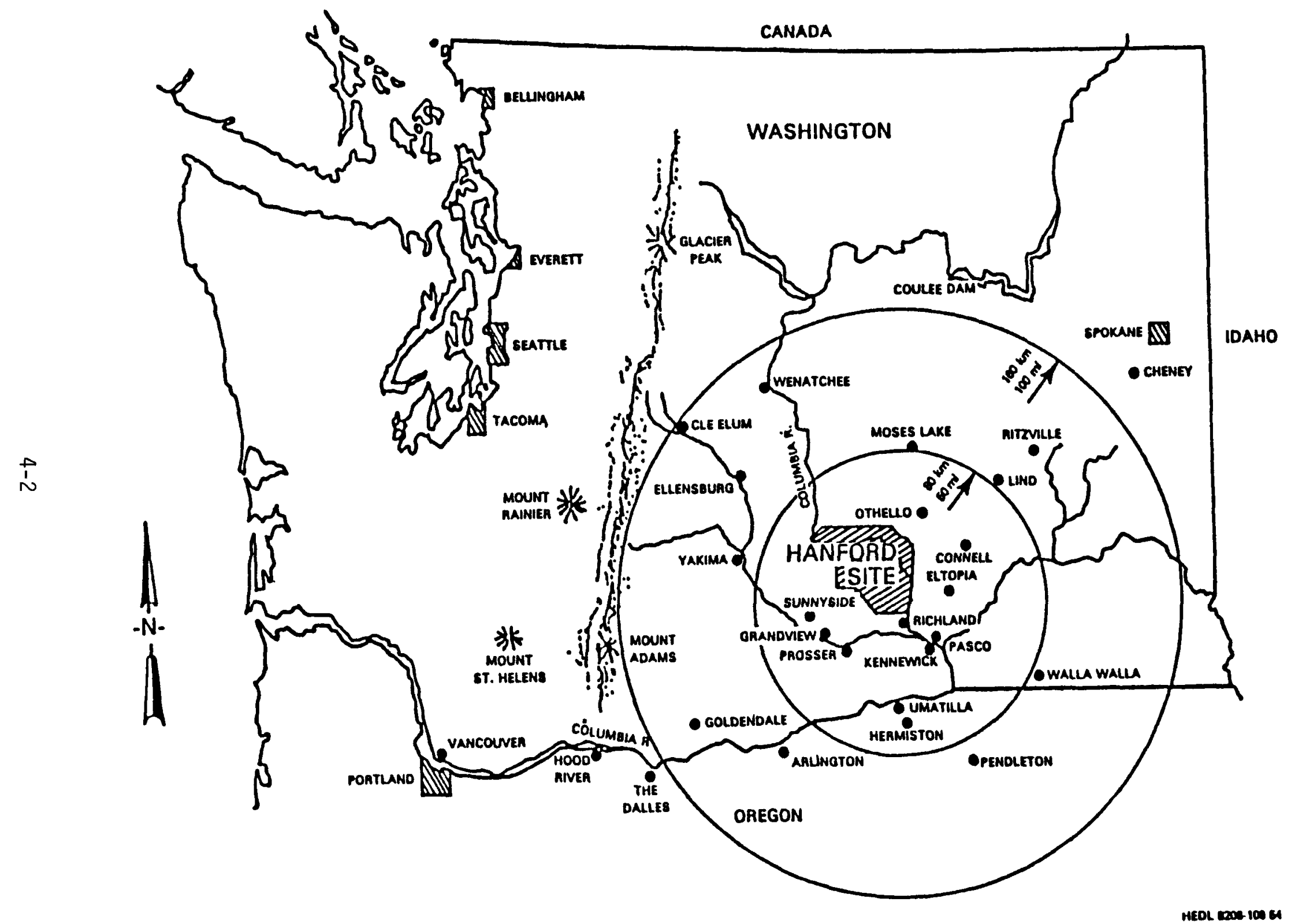

FIGURE 4.1. Location of Hanford Site Within Washington State. 


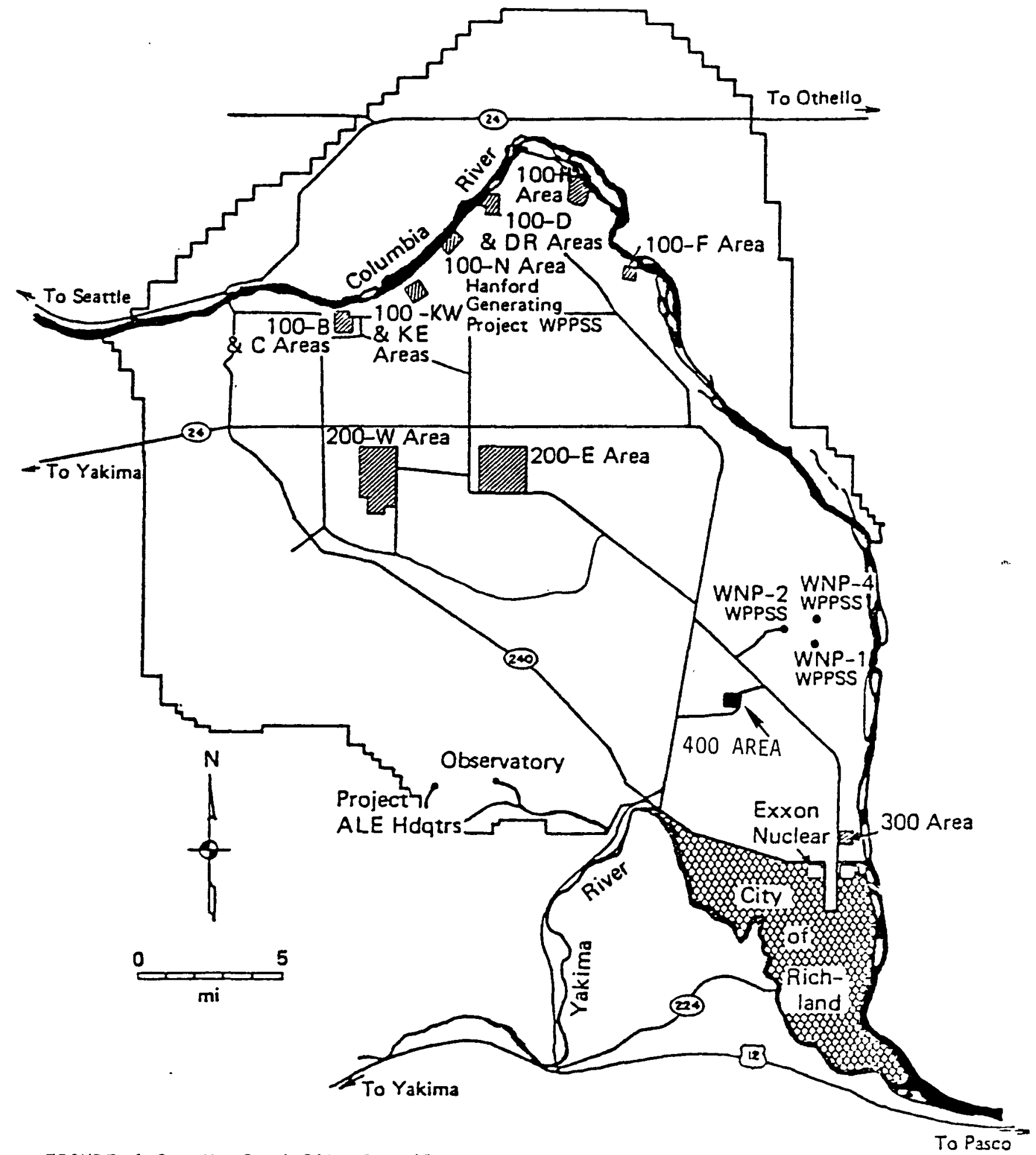

FIGURE 4.2. Hanford Site Details. 


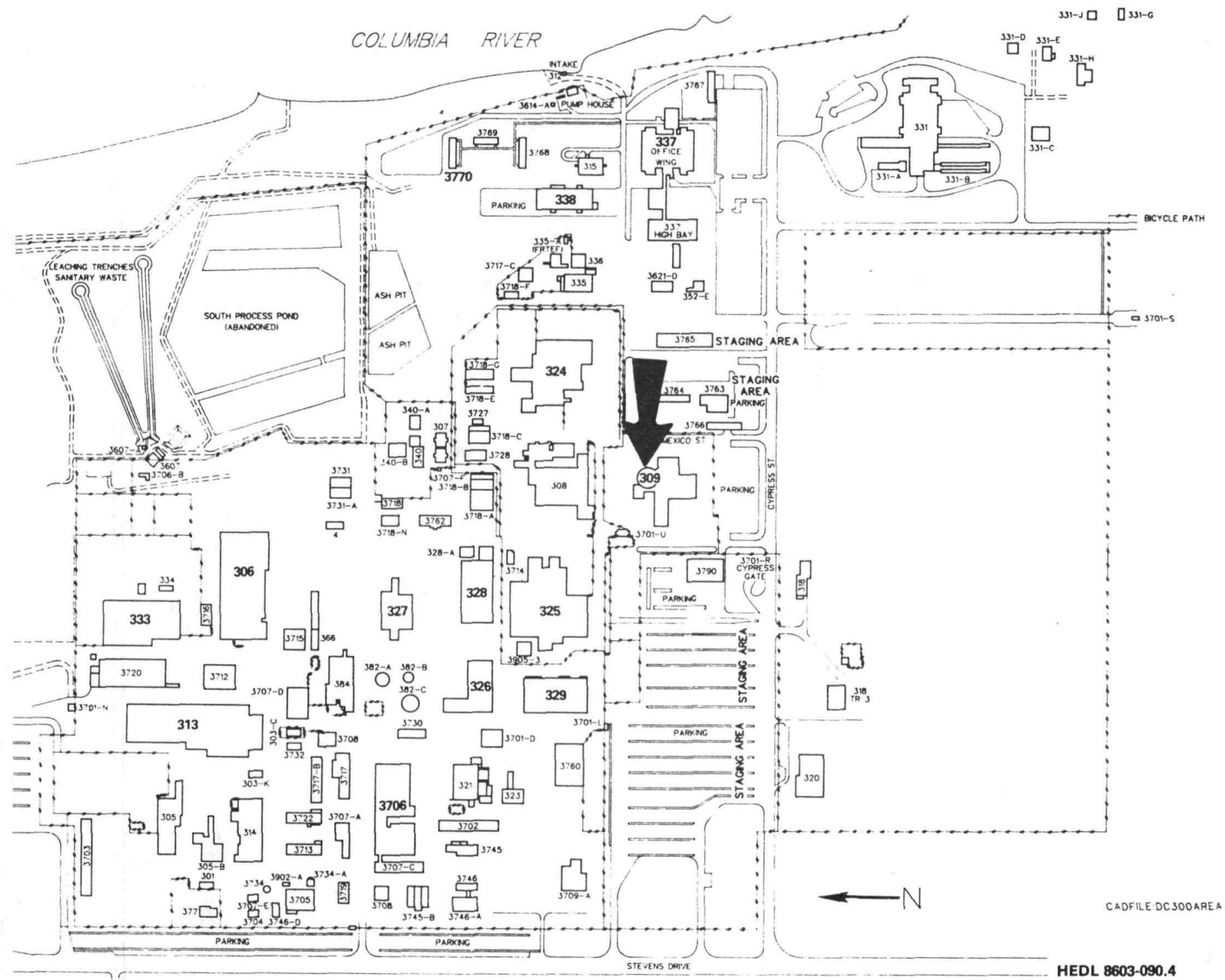

FIGURE 4.3. Hanford 300 Area Details. 
immediately across the river from the 300 Area. The nearest city water intake is the Richland city pumping station $6 \mathrm{~km}(3.7 \mathrm{mi})$ downstream from the 300 Area.

Principal activities in the 300 Area facilities include reactor fuels research and development, liquid metal technology development, life sciences research, and FFTF reactor support. In 1981, the peak daytime working population was 3100 ; no significant change has occurred since then.

The nearest city (Richland, Washington) has a population of $33,578 .(4.8)$ The Tri-Cities (Richland, Kennewick, and Pasco) make up the nearest population center. They have a combined population in excess of 80,000 . In 1980, the total population within an $83-\mathrm{km}(50-\mathrm{mi})$ radius of the 300 Area was 264,541.(4.9) (See Table 4.1 and Figure 4.4.) The projected 1990 population within the same $83-\mathrm{km}(50-\mathrm{mi})$ radius is $327,825 .(4.9)$ However, recent employment, construction activity, and population influx have been less than postulated for the 1990 population forecast. Thus, the actual 1990 population within $83 \mathrm{~km}(50 \mathrm{mi})$ is expected to be less than the values used for the population dose estimates given in this Environmental Assessment.

\subsubsection{Regional and Site Activities}

Adjacent to the Hanford Site are residential suburban, corporate city, agricultural, industrial, commercial, scenic, recreational, and general-use areas. Agriculture is the main land use within an 83-km (50-mi) radius of the 300 Area.

\subsubsection{Socioeconomics}

Socioeconomic parameters of concern include employment, personal income, population, demographic characteristics, housing, recreation, health care, and public finance. Detailed reviews of area socioeconomics are given in References 4.10 through 4.13 . 
TABLE 4.1

POPULATION DISTRIBUTION FOR 1990 WITHIN 83-km (50-mi) RADIUS

OF HANFORD 300 AREA BY POPULATION GRID SECTOR

\begin{tabular}{|c|c|c|c|c|c|c|}
\hline Compass & & & Number & People & & \\
\hline Direction & $0-10 \mathrm{mi}$ & $10-20 \mathrm{mi}$ & $20-30 \mathrm{mi}$ & $30-40 \mathrm{mi}$ & $40-50 \mathrm{mi}$ & Totals \\
\hline NORTH & 393 & 328 & 1,252 & 6,995 & 6,243 & 15,211 \\
\hline NNE & 417 & 647 & 1,092 & 2,415 & 2,681 & $7,25 ?$ \\
\hline NE & 24 & 1,314 & 3,515 & 738 & 256 & 5,847 \\
\hline ENE & 417 & 634 & 476 & 631 & 305 & 2,463 \\
\hline EAST & 395 & 155 & 180 & 194 & 764 & 1,688 \\
\hline ESE & 459 & 370 & 963 & 659 & 19,882 & 22,333 \\
\hline SE & 3,469 & 35,104 & 3,469 & 988 & 1,471 & 44,501 \\
\hline SSE & 9,310 & 38,936 & 1,425 & 1,333 & 1,328 & 52,332 \\
\hline SOUTH & 19,951 & 8,526 & 123 & 20,548 & 6,117 & 55,265 \\
\hline SSW & 14,260 & 5,173 & 128 & 1,418 & 2,373 & 23,352 \\
\hline SW & 12,904 & 5,040 & 905 & 229 & 215 & 19,293 \\
\hline WSW & 5,679 & 2,319 & 7,067 & 10,460 & 722 & 26,247 \\
\hline WEST & 377 & 1,261 & 2,718 & 19,611 & 18,932 & 42,899 \\
\hline WNW & 0 & 0 & 868 & 1,815 & 1,945 & 4,628 \\
\hline NW & 0 & 0 & 95 & 1,084 & 876 & 2,055 \\
\hline NNW & $\underline{0}$ & $\underline{0}$ & $\underline{9}$ & 1,028 & 1,422 & 2,459 \\
\hline TOTALS & 68,055 & 99,807 & 24,285 & 70,146 & 65,532 & 327,825 \\
\hline
\end{tabular}




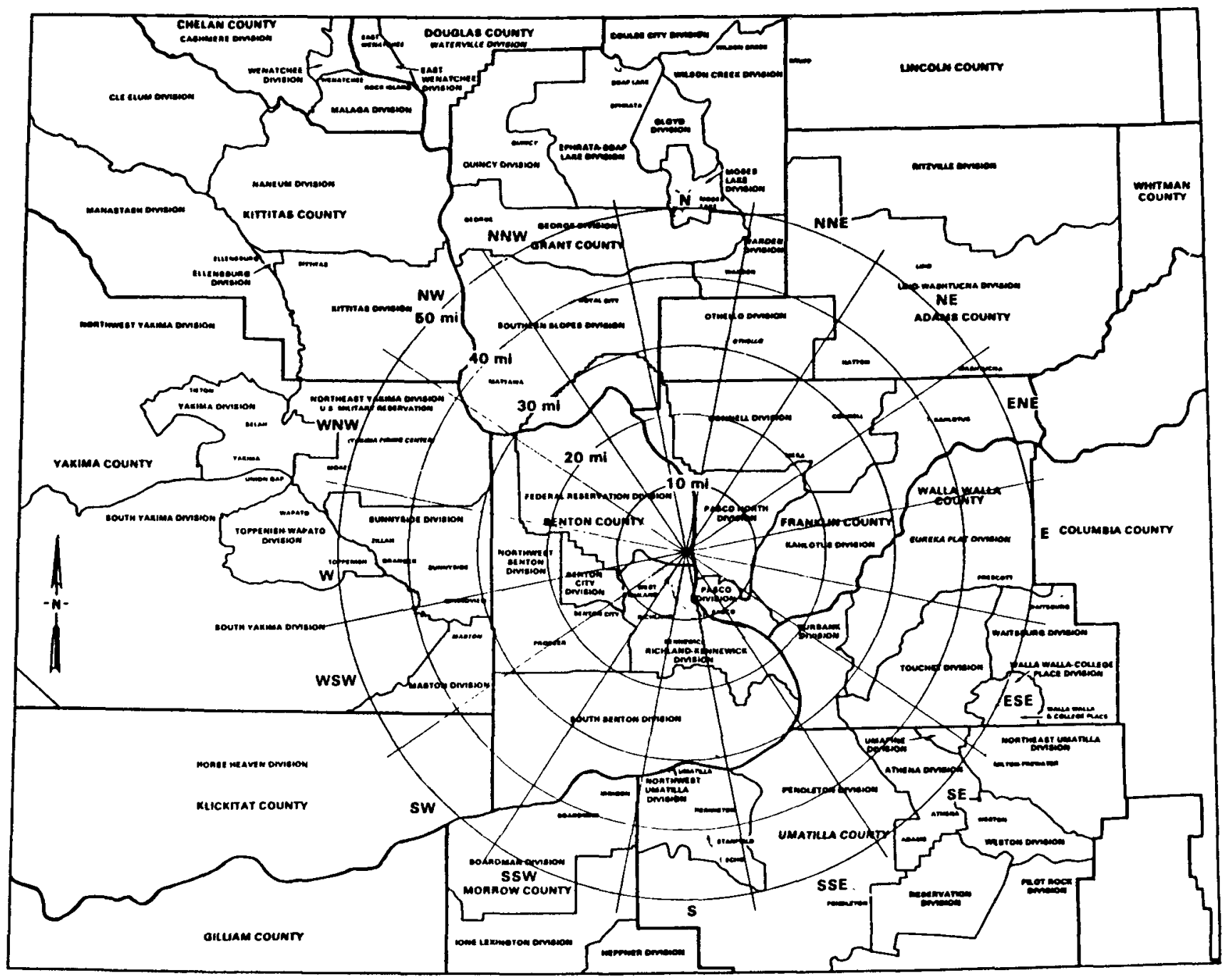

FIGURE 4.4. 83-km (50-mi) Radius from Hanford 300 Area. 
The extensive nuclear-related development work that was initiated by the U.S. Government in 1943 has greatly influenced the socioeconomic growth of the region surrounding the Hanford Site. Construction and project activities have been significant for many years. The influx of temporary and permanent personnel has already had major effects on the rate of community growth, patterns of indirect business development, and community social structure.

The SP-100 GES Project is projected to last through 1995. Project staffing includes five major components: planning, engineering, construction, operations, and decommissioning. Projected peak staffing, estimated for 1990 , will total less than 100 people. The construction staff will peak in 1990 and 1991, the operations staff in 1992, and the decommissioning staff in 1994. All positions are projected to come from the existing area work force. The total Hanford Site (nonconstruction-related) work force for DOE activities, including facilities operations, was about 12,000 in 1988 but is declining.

\subsubsection{Physical Environment}

This section sumnarizes the physical characteristics (geology and topography, hydrology, climatology, and seismicity) of the Hanford Site. More extensive and detailed technical information about the site and the surrounding region is found in References 4.1 through $4.7,4.11$, and 4.14 through 4.26 .

\subsubsection{Geology and Topography}

The Hanford Site is located in southeastern Washington in the Pasco Basin, part of the Columbia Plateau. The Hanford Site land surrounding the 300 Area is devoid of prominent surface features. Approximately $85 \%$ of the 1 and in the 300 Area is occupied by structures or facilities; the remainder has a sparse vegetation cover.

The Hanford Site (including the 300 Area) is underlaid by three major stratigraphic units. The Columbia River Basalt Group that forms the bedrock beneath the site is estimated to be more than $3,600 \mathrm{~m}(12,000 \mathrm{ft})$ thick. 
The Ringold Formation, consisting of semiconsolidated sediments, lies directly over the bedrock. It is up to about $300 \mathrm{~m}(1000 \mathrm{ft})$ thick. Unconsolidated silts, sands, and gravels known as the Hanford Formation lie over the Ringold Formation. These unconsolidated materials are up to $61 \mathrm{~m}$ $(200 \mathrm{ft})$ thick. A thin ( $15-\mathrm{m}$ thick) layer of wind-transported sands and silts, which has been largely stabilized by vegetation, covers the Hanford Formation.

\subsubsection{Hydrology}

The Columbia River flows through the northern part of the Hanford Site and along the eastern boundary. No other natural water-courses lie within or adjacent to the 300 Area. The 300 Area is elevated about $120 \mathrm{~m}$ (394 ft) above mean sea level. This is about $15 \mathrm{~m}(49 \mathrm{ft})$ above the average elevation of the adjacent Columbia River, which is $105 \mathrm{~m}(345 \mathrm{ft}$ ) above mean sea level. The estimated 100-yr maximum flood would result in a river level of $108.5 \mathrm{~m}$ $(356.0 \mathrm{ft})$. The U.S. Corps of Engineers' Probable Maximum Flood would result in a river level of $116.5 \pm 1.2 \mathrm{~m}(382 \pm 4 \mathrm{ft})$ at the 300 Area. (4.1) Flooding of the 300 Area by rainwater is improbable, since the sands and gravels underlying it are highly permeable.:

Groundwater enters the 300 Area from the northwest, west, and southwest and flows into the Columbia River. The elevation of the water table typically varies from $103.7 \mathrm{~m}(340.2 \mathrm{ft})$ to $104.4 \mathrm{~m}(342.5 \mathrm{ft})$ above mean sea level.

\subsubsection{Seismicity}

The Hanford Site is designated as a Zone II area, as determined by the U.S. Coast and Geodetic Survey. (4.7) The intensity of the strongest earthquake at Hanford in historic times has not been greater than IV on the Modified Mercalli Intensity Scale (MM IV). (4.2) The largest potential earthquake generator near Hanford is the Rattlesnake-Wallula fault, which is about $12.9 \mathrm{~km}(8 \mathrm{mi})$ west of the 300 Area. The Hanford Site earthquake potential has been extensively characterized and modeled. The seismic hazard has been quantified in terms of the Peak Ground Acceleration (PGA) return period, 
which is the inverse of the annual probability of exceeding a specific PGA (Figure 4.5). Further, the site seismic hazard has been characterized in terms of spectral accelerations. $(4.27)$

\subsubsection{Climatology}

The climate at the Hanford Site is characterized by relatively cool, mild winters and long, warm summers. (4.3) The average rainfall at Hanford is $16 \mathrm{~cm}$ ( $6.3 \mathrm{in.})$. Tornadoes rarely occur, but tend to be small and produce little damage if they do occur. The Hanford Site tornado and high wind potentials have been characterized and modeled. Tornado and high wind hazard is quantified as the annual probability that any point within a geographic region (e.g., the Hanford Site, as shown in Figure 4.6) will experience wind speeds in excess of some threshold value. (4.28)

\subsubsection{Background Radiation}

The annual dose from natural background radiation to someone 1 iving anywhere in the vicinity of Hanford is about 100 mrems. $(4.21,4.23)$ In 1984, the per capita whole-body dose from a11 DOE Hanford operations to the population residing within an $80 \mathrm{~km}$ radius of one or more of the operating sites, was about 0.01 mrem. (4.21) In 1984, the whole-body dose to the maximum individual (nearest resident) from all DOE Hanford operations was about 2 mrems. In 1984, the whole-body population dose was about 5 person-rems from DOE Hanford Operations. (4.21)

\subsubsection{Ecology}

The Hanford Site has a sparse covering of vegetation. The most broadiy distributed vegetations are sagebrush and bitterbrush with an understory of cheatgrass and Sandberg's bluegrass. Larger mammals within the Hanford Site include mule deer, elk, raccoon, beaver, muskrat, and mink. They are usually found close to the Columbia River. Coyotes and jackrabbits are widely distributed throughout the Site. Small mammals are abundant with the 


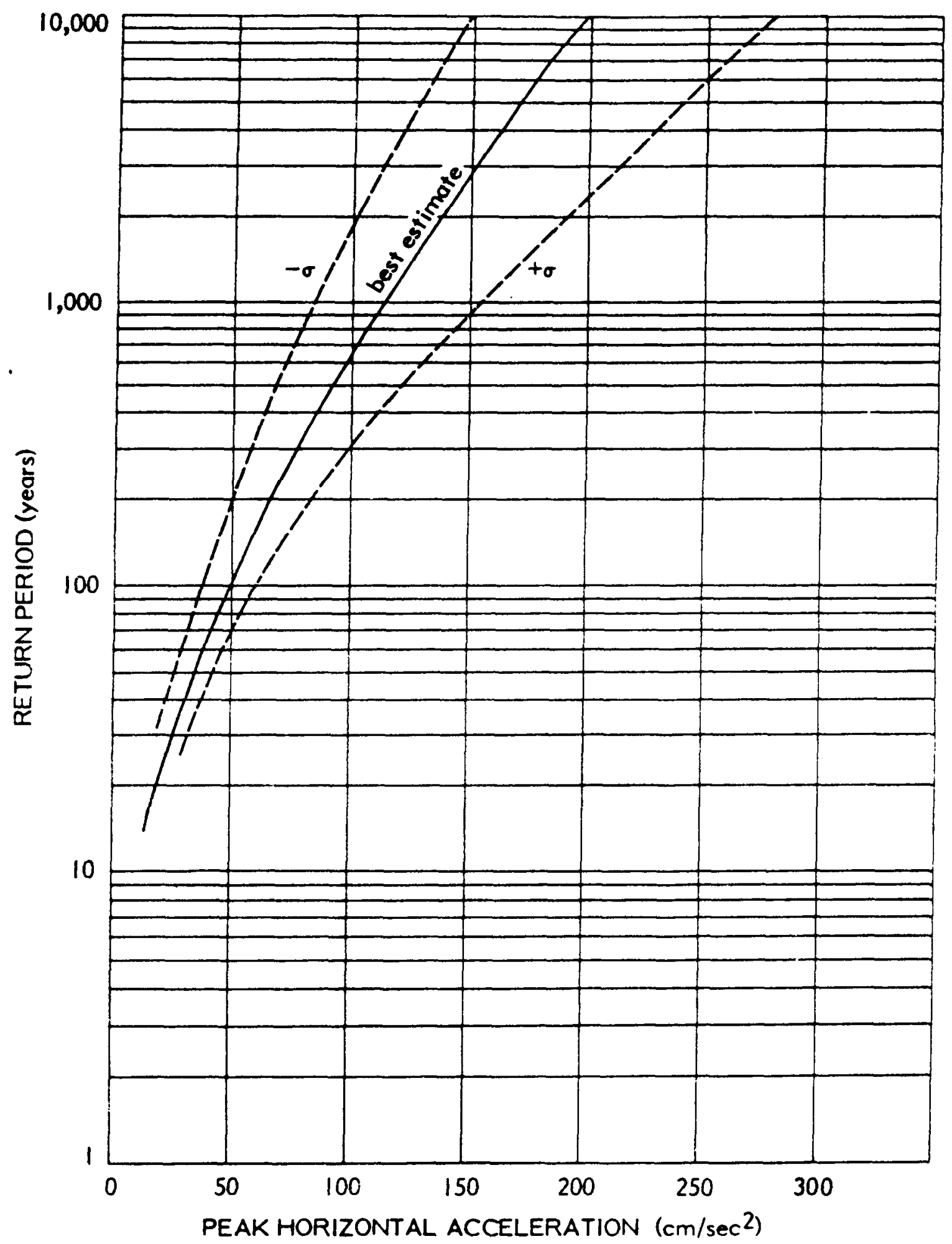

FIGURE 4.5. Hanford Site Earthquake Hazard. (4.27) 


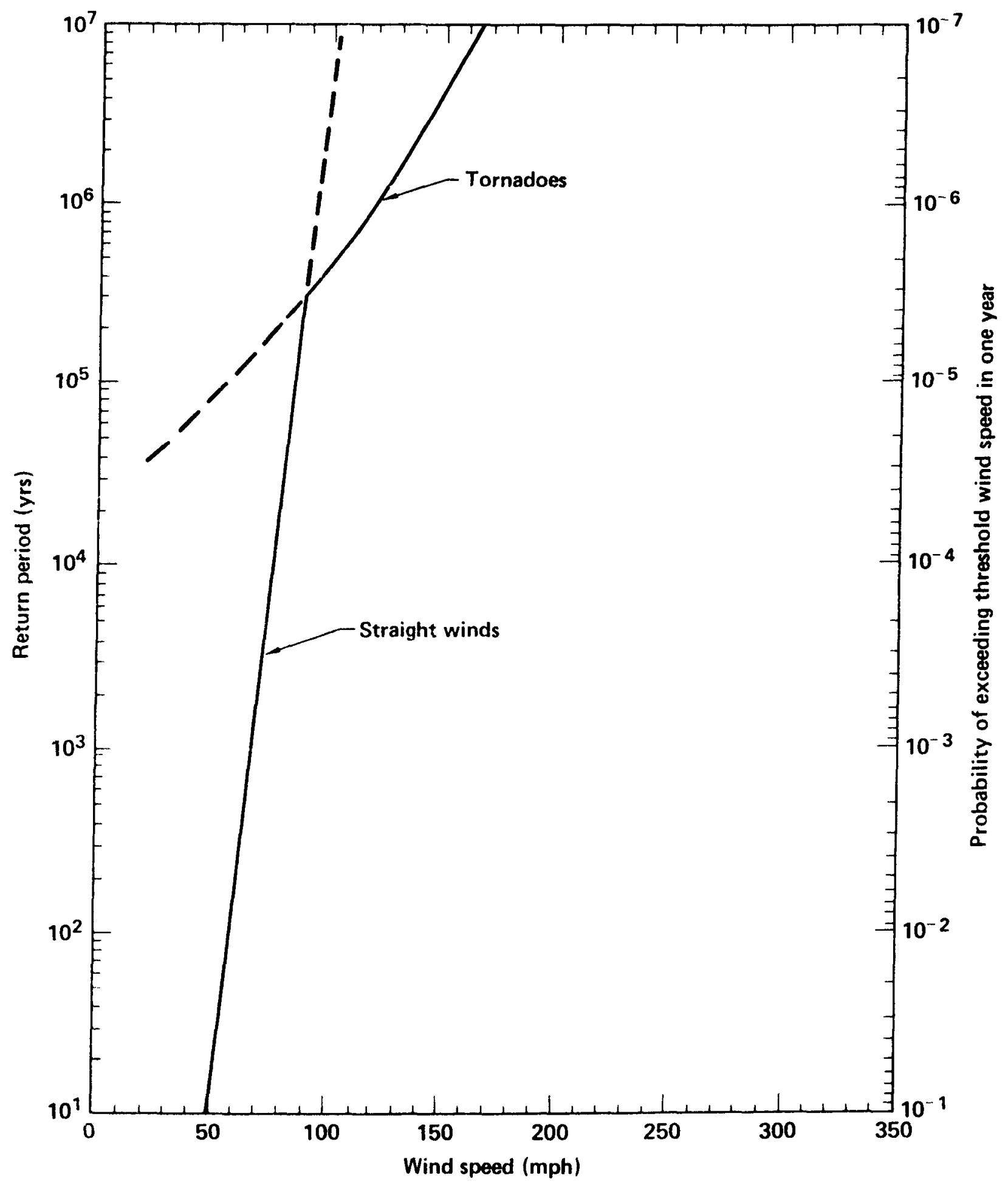

FIGURE 4.6. Hanford Site Wind Hazard. (4.28) 
Great Basin pocket mouse being the most plentiful. The chukar partridge, Chinese ringneck pheasant, California quail, ducks, and Canada geese are also numerous. Migratory waterfowl are usually found along the Columbia River but occasionally use waste ponds and ditches. There are no endangered plant species on the Hanford Site 300 Area. Several forms of wildlife require consideration. Both federal and state authorities consider the peregrine falcon to be an endangered species and the bald eagle a threatened species. No threatened or endangered species have been identified within the 300 Area.

\subsubsection{Archeology}

In prehistoric times, the Columbia Basin was densely occupied by numerous camps and villages of various Plateau Indian groups. Today, the Hanford reach of the Columbia River contains the only intact remaining evidence of these native cultures. (4.13) Present1y, nine archeological properties on the Hanford Site are listed in the Washington State Register of Historic Places. (4.14) A total of 115 archeological sites are on or adjoin the Hanford Site, including open camps, fishing stations, house pit sites, and cemeteries. $(4.12)$

The area considered for construction activity has been extensively disrupted by prior 300 Area construction activities. A cultural resource review will be performed prior to construction. 


\subsection{ENVIRONMENTAL CONSEQUENCES}

Potential environmental impacts of the SP-100 GES Test Site project during modification of the 309 Building, equipment installation, test operation, and site restoration phases have been evaluated, and the results are presented in this section. In summary, no adverse environmental impacts of any consequence are expected from construction or operation of the SP-100 GES Test Site.

\subsection{ENVIRONMENTAL CONSEQUENCES OF PROPOSED TEST SITE ACTION}

\subsubsection{Construction Impacts}

Local temporary environmental impacts will occur during the modifications to the 309 Building for the SP-100 GES Test Site activity. Noise levels will be increased, especially within the 309 Building, but will comply with the standards presented by applicable DOE Order. (5.1) Since the proposed activity involves principally the refurbishing of selected interior sections of an existing building, impacts to the environment will be minimal and minor.

Soil disturbance during this construction activity will be limited to the area where the DHXs, electrical substation, and chiller support pads will be installed. The area immediately surrounding the 309 Building is in an existing industrial area and has been extensively disturbed previously. Blowing sands and dusts will not be increased over present amounts. No additional land commitment will be required as a result of 309 Building modification.

\subsubsection{Radiological Impacts, Startup Testing, and Normal Operations}

\subsubsection{Gaseous Releases}

All effluents will meet or be below applicable DOE release criteria as well as federal and state requirements (see Section 7.0) by design. Routine gaseous releases will be minimized by design, as discussed below. 
Three sources of radioactive gas exist: fission product gases, vacuum vessel cavity activation gases, and tritium produced by nuclear-induced reactions within the core. Routine releases of fission product gases (isotopes of xenon and krypton) will be precluded by design; they will be contained within the sealed fuel pins. In the unlikely event that a fuel pin fails, fission product gases would collect in the sealed cover gas system. Subsequent holdup would allow for adequate decay to ensure no significant release; concentrations will be below concentration guidelines for radioactive gas releases, as established by DOE Order (see Section 7.1).

Activation products formed in the cell atmosphere around the vacuum vessel would result primarily from activation of the trace argon present in the atmosphere of that cell. Argon activation will be reduced by near-reactor shielding. Other atmospheric activation products (nitrogen-16 and oxygen-19) are produced in substantially lower amounts and have shorter half-lives than argon-41; provisions for treatment of argon activation will suffice to ensure that no other measurable gaseous release from cell activation occurs.

Tritium (hydrogen-3) production primarily results from activation of lithium (used for the primary coolant and for the shield). Tritium diffuses readily through metal boundaries such as the primary coolant boundary at elevated temperature. The majority of the tritium will be collected by the vacuum pumps (central path in Figure 5.1) and will then be held up for final disposal in the Tritium Removal System. A small fraction (less than 1 part in $10^{9}$ ) of the tritium will pass through the Tritium Removal System and be discharged through the exhaust stack into the atmosphere. An equally small quantity of tritium will diffuse through the IHX and the DHX into the atmosphere (lower path in Figure 5.1). This release will be further reduced by removing tritium from the secondary sodium with a cold trap. A third mechanism for tritium release results from the use of anhydrous ammonia for core cleaning following reactor operation. 


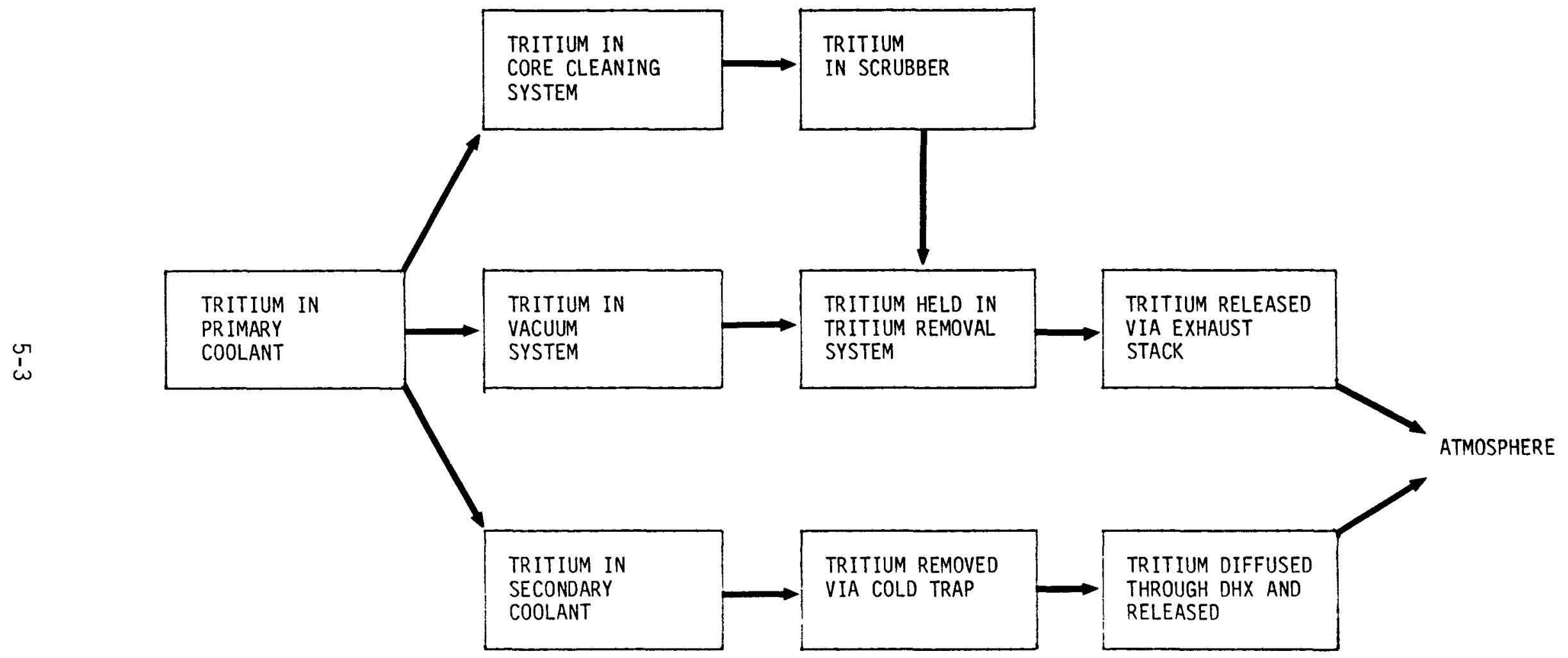

FIGURE 5.1. Tritium Release Scenarios. 
Anhydrous ammonia will be used to dissolve residual lithium (and a small amount of tritium dissolved in the lithium) after most of the lithium is drained. The waste anhydrous ammonia will be vaporized, passed through a scrubber solution to react the ammonia, passed through the Tritium Removal System to capture the tritium inventory, and discharged up the stack. Tritium emissions will be below applicable emission standards (see Section 7.1).

No source of particulate material has been identified for routine operation. Existing HEPA filter capability will be retained, and exhaust will be passed through these filters. Consequently all emissions will meet applicable air quality and hazardous air pollution emission standards (see Sections 7.2 , 7.3, and 7.6).

Estimates of the quantities of radionuclides released (i.e., the source terms) from SP-100 GES Test Site operations under normal operations are presented in Table 5.1 (see Appendix B for projection bases). (5.2)

TABLE 5.1

ANNUAL AIRBORNE RADIOACTIVE MATERIAL RELEASEO FROM LIGHT WATER REACTORS (1981), FFTF (1984), AND SP-I00 GES TEST (PROJECTED)

\begin{tabular}{|c|c|c|c|}
\hline \multirow[b]{2}{*}{ Reactor Type } & \multicolumn{3}{|c|}{ Airborne Activity $\left(\mathrm{C} i^{\star}\right)$} \\
\hline & $\begin{array}{c}\text { Fission and } \\
\text { Activation Gases }\end{array}$ & Particulates & Tritium \\
\hline Boiling Water & 50,000 (average) & 1 (average) & $\star \star$ \\
\hline $\begin{array}{l}\text { Pressurized } \\
\text { Water }\end{array}$ & 4,000 (average) & 0.1 (average) & $\star \star$ \\
\hline FFTF & 20 & 0 & $<10^{-2 \star \star \star}$ \\
\hline$S P-100$ & $3.7\left(4 l_{A r}\right)$ & 0 & $4.7 \times 10^{-2}$ \\
\hline
\end{tabular}


Maximum individual and population doses resulting from projected chronic releases of all materials were calculated (see Appendix D). The maximum whole body dose commitment to the nearest resident is $4.5 \times 10^{-4} \mathrm{mrem}$. The 50-yr whole body dose commitment for the population within $83 \mathrm{~km}(50 \mathrm{mi})$ was projected to be $2.7 \times 10^{-3}$ person-rem. This would result in negligible increased risk of health effects $\left(1.4 \times 10^{-6}\right.$ latent cancer fatalities). For perspective, these doses are much smaller than the background radiation doses summarized in Section 4.1.4.5 and much smaller than 40 CFR $61.92^{(5.3)}$ limits of $25 \mathrm{mrem} / \mathrm{yr}$ whole body or $75 \mathrm{mrem} / \mathrm{yr}$ critical organ for any member of the general public.

\subsubsection{Radioactive and Mixed Waste Generation}

Radioactive and mixed waste will be generated as a result of routine operational decontamination. The operations would be comparable to liquid metal handling operations and destructive fuel examination activities currently performed at 300 Area facilities. A large liquid metal-cooled reactor, the FFTF, generated $1000 \mathrm{ft}^{3}$ of radioactive solid waste in 1985 . Also $15,000 \mathrm{ft}^{3}$ of solid waste were handled in the 300 Area during the same year. The SP-100 Test Site operations can be conservatively expected to generate less than the FFTF; hence the waste volume generated is anticipated to amount to less than $1,000 \mathrm{ft}^{3}$ or less than $7 \%$ of the total for the 300 Area. Specific materials that have been identified as potentially requiring radioactive or mixed solid waste disposal include used air filters, decontamination materials, primary and secondary system liquid metal cold traps, hot traps, tritium traps, solidified liquid waste, lithium cleaning residue, reactor disassembly equipment, activated shielding materials, and primary system structural components. Existing Hanford storage or disposal facilities will be used; several hundred thousand cubic feet of radioactive waste are disposed of annually on the Hanford Site.

Evaluations of the anticipated radioactive liquid waste have bounded the maximum 1 iquid waste generation at $300 \mathrm{gal} / \mathrm{yr}$. This was determined by a comparison of SP-100 activities with FFTF activities that generate 1 iquid waste and a survey of other potential liquid waste sources. The primary liquid waste source, which will be reduced substantially below 
$300 \mathrm{gal} / \mathrm{yr}$ by design, is condensation of airborne moisture in air cooling units. Because it may contain trace amounts of tritium, it will be treated as radioactive. The relatively small amount of liquid waste will be disposed of by stabilizing the water. The product will then be disposed of as low-level solid waste in the Hanford 200 Area Burial Ground facilities. Disposal in the Hanford 200 Area Burial Ground is managed to ensure conformance with applicable DOE Orders. No disposal of liquid waste to soil columns will result from SP-100 activities.

Mixed waste results from the activation or contamination by radionuclides of hazardous materials that then require disposal. The liquid metal cold and hot traps, which will contain activated materials trapped from the coolant, will be disposed of as mixed waste. The primary potential source of such material is the primary lithium and secondary sodium coolant for the reactor. Past experience has shown that such coolant is not disposed of but is recycled (e.g., sodium coolant for the decommissioned Hallam reactor will be used as secondary coolant for the SP-100 GES Test facility). If disposal is necessary, the liquid metal would be neutralized and disposed of as mixed waste.

Disposal of low-level radioactive and mixed wastes will be accomplished by burial in the Hanford 200 Area Burial Ground. These grounds are operated to ensure compliance with current DOE regulations. Both storage and disposal of mixed waste will meet the requirements of the Resource Conservation and Recovery Act (RCRA) as amended by the Hazardous and Solid Waste Amendments of 1984, including restrictions on storage and disposal of hazardous waste.

\subsubsection{Occupational Exposure}

The SP-100 GES Test Site is being designed with state-of-the-art technology to maintain exposures as low as reasonably achievable (ALARA). The design objectives are such that no employee is expected to receive a dose greater than $1000 \mathrm{mrem} / \mathrm{yr}$ in normally occupied zones and during anticipated maintenance. Routinely accessible areas are limited to radiation fields of $2 \mathrm{mrem} / \mathrm{h}$ by Westinghouse Hanford Company policy; other areas will be administered as limited or restricted access areas. Exposure experience 
at the FFTF from 1982 through the 3rd quarter of 1986, with similar design and administrative restrictions imposed, shows that no individual has been exposed to a dose exceeding $290 \mathrm{mrem} / \mathrm{yr}$ and that the collective dose has averaged 6.2 person-rems with a maximum collective exposure in 1984 of 13 person-rems, resulting from an extensive maintenance operation. No appreciable occupational exposure is projected from routine airborne releases.

These exposures are within limits for occupational workers (see Section 7.1).

\subsubsection{Nonradiological Impacts, Startup Testing, and Normal Operations}

\subsubsection{Thermal Discharges}

The SP-100 GES Test activities will result in thermal discharges to the atmosphere. Reactor heat (2.5 MWt maximum) will be dissipated to the atmosphere using a forced-air DHX. Additionally, air conditioning will be provided to remove heat from selected equipment and support areas. An amount equal to less than $20 \%$ of the reactor heat will be discharged via air conditioning and ventilation. No environmental consequences are anticipated from this thermal discharge. For comparison, the FFTF located in the 400 Area (Figure 4.2) rejects reactor heat amounting to $400 \mathrm{MWt}$ via forced-air DHXs. The impact of rejecting the SP-100 GES reactor heat will be 1/160th of the impact of heat rejection from the FFTF. The environmental consequences projected for the FFTF show no significant effect outside the immediate FFTF area. (5.4) Operational experience at the FFTF has confirmed no adverse impact. Minimal effect, even in the immediate vicinity of the SP-100 test area, is expected.

\subsubsection{Hazardous Materials}

The facility will be designed to prevent the release of hazardous materials. As an example, anhydrous ammonia will be used to clean the irradiated primary system of residual lithium. The anhydrous ammonia will be neutralized by bubbling it through an acidic bath prior to discharge. The bath will be designed to preclude measurable release of ammonia vapors 
from the exhaust stack. The acid bath will be neutralized, and the residue will be disposed of as hazardous waste or potentially mixed waste, as discussed in Sections 5.1.3.3 or 5.1.2.2, respectively.

Other hazardous material use will consist primarily of alkali metals as reactor cooling media and beryllium oxide as a reactor reflector. The facility will be designed to contain liquid metals, to minimize the effects of liquid metal leakage, and to limit the risk from beryllium. No routine operational release of these materials will occur. Additionally, commonly used hazardous materials such as ethylene glycol will be used as the cooling medium in air conditioning systems; controls on handling waste glycol will ensure that no discharges will be made to the environment.

Regulated pollutant emissions will be minimal, ensuring conformance with requirements for prevention of air quality deterioration, as addressed by 40 CFR 50(5.5) (see Section 7.2). Similarly, hazardous materials emissions are not planned; this will ensure conformance with 40 CFR 61.92 (5.3) (see Section 7.3). Further, compliance with Washington State regulations will be ensured (see Sections 7.6 and 7.8).

\subsubsection{Hazardous and Nonradiological Solid Waste Generation}

Westinghouse has experience with similar operations at the FFTF. (5.2) Experience with liquid-metal reactor operation at the FFTF (with comparable systems) has resulted in limited hazardous waste generation; on $1 y 120 \mathrm{ft}^{3}$ were generated in 1986. Estimates based on these operations and a survey of expected materials usage determined that less than $100 \mathrm{ft}^{3}$ of hazardous waste will be generated per year of SP-100 operation. The largest single item identified for disposal as hazardous waste is the lithium purification hot trap; it represents $\sim 10 \mathrm{ft}^{3}$ of hazardous waste to be disposed of during the startup testing phase. Any hazardous nonradiological wastes will be segregated following existing Hanford procedures. Interim hazardous waste staging will be provided onsite. Final hazardous waste disposal is performed by a RCRA-permitted contractor, with final disposal by neutralization or by placement in an offsite dangerous waste 1 andfill. 
Nonradiological, nonhazardous solid wastes, composed of trash and normal industrial solid wastes, will be disposed of in a central sanitary landfill. The SP-100 contribution is estimated to be less than $18,000 \mathrm{ft}^{3} / \mathrm{yr}$, les $\mathrm{s}$ than $6 \%$ of the present 300 Area nonradiological solid waste and less than $1 \%$ of the total central sanitary landfill load.

Transportation, handling, and disposal of hazardous wastes will be performed in conformance with applicable provisions of 40 CFR 260-266 (5.6-5.12) and Washington Administrative Code (WAC) 173-303 (see Sections 7.5 and 7.8).

\subsubsection{Potential Accident Impacts}

An evaluation was performed to identify environmental impacts resulting from a spectrum of accidents associated with operation of the SP-100 GES Test Site (Appendices $B$ and $C$ ). The evaluation of the accidents and their impacts for the SP-100 GES Test Site determined that the most significant environmental impact would be associated with an extremely unlikely accident involving the release of the fission product inventory contained by the reactor following extended operation. Other potential accidental releases include activation products, alkali metals, and toxic materials.

When a high impact level was identified, specific accident scenarios for acute release were developed, and an assessment was made of the risk of these potential accidents. The detailed analyses of the results of release of radioactive materials following these scenarios are summarized in Table 5.2 and listed in Appendix $C$. The following discussion outlines the developed accident scenarios including treatment of a low-impact, nonradioactive, primary lithium spill.

Event likelihood was classified using the following system. Anticipated events are off-normal conditions that individually would be expected to occur once or more during plant operations. Unlikely events would not be expected to individually occur during the plant lifetime $\left(10^{-2}\right.$ to $10^{-6}$ per year), but collectively an event in this category may occur. Extremely uniikely events are extremely low probability $\left(10^{-6}\right.$ to $10^{-8}$ per year $)$ 
TABLE 5.2

SUMMARY OF RADIOLOGICAL ACCIDENT ANALYSES AND CONSEQUENCES

FOR EXTREMELY UNLIKELY EVENTS

( $10^{-6}$ to $10^{-8}$ PROBABILITY)

\begin{tabular}{|c|c|c|c|c|}
\hline $\begin{array}{c}\text { Radiological Accident } \\
\text { Evaluated } \\
\end{array}$ & $\begin{array}{l}\text { Offsite } \\
\text { Maximum } \\
\text { Individ- } \\
\text { ual Whole } \\
\text { Body Dose } \\
\text { (rem) } \\
\end{array}$ & $\begin{array}{l}\text { Onsite } \\
\text { (Worker) } \\
\text { Individ- } \\
\text { ual Whole } \\
\text { Body Dose } \\
\text { (rem) } \\
\end{array}$ & $\begin{array}{l}\text { Collective } \\
\text { Popula- } \\
\text { tion Dose } \\
\text { (person- } \\
\text { rem) } \\
\end{array}$ & $\begin{array}{l}\text { Projected } \\
\text { Mortality } \\
\text { Rate } \\
\text { (Latent } \\
\text { Cancer } \\
\text { Fatal- } \\
\text { ities per } \\
\text { Accident) }\end{array}$ \\
\hline $\begin{array}{l}\text { Irradiated Fuel } \\
\text { Handling Accident } \\
\text { Following Extended } \\
\text { Operation and Cooldown }\end{array}$ & $4.8 \times 10^{-4}$ & $4.2 \times 10^{-3}$ & 0.17 & $1 \times 10^{-4}$ \\
\hline $\begin{array}{l}\text { Accidental Tritium } \\
\text { Release from Tritium } \\
\text { Removal System }\end{array}$ & 0.22 & 2.0 & 5.6 & $3 \times 10^{-3}$ \\
\hline $\begin{array}{l}\text { Secondary Coolant } \\
\text { System Leak and Fire }\end{array}$ & 0.021 & 0.19 & 0.53 & $3 \times 10^{-4}$ \\
\hline
\end{tabular}

conditions that are not expected to occur during the plant 1 ifetime; rather they represent the extreme of limiting cases of events that are identified as possible. Three of the five accidents analyzed below were determined to be extremely unlikely events and consequently were chosen as bounding events for assessing environmental impact. The other two accidents represent unlikely events and have negligible environmental impact.

\subsubsection{Unirradiated Fuel Handling Accident}

The UN fuel, which has been taken from stockpile and fabricated in existing facilities at Los Alamos National Laboratory, will be transported to the 309 Building containment in a shipping cask that complies with DOE Orders for fuel shipment (see Section 7.10). After the core materials have been moved into the facility, confinement capability will be maintained. The dry fuel material will then be transferred into the reactor vessel, and the reactor vessel will be sealed. The reactor vessel, already attached to a spool piece of the vacuum vessel, will then be sealed. Handling and lifting 
operations will be carefully controlled by procedure; however, failure of equipment or procedure might occur. The postulated accident (which bounds the range of credible fuel handling accidents) is initiated by a major crane failure. The resulting load drop significantly damages the reactor vessel and core with breach of the fuel cladding, fracturing of the fuel, and release of respirable uranium nitride fuel particles into the containment atmosphere. It is further assumed that the respirable material is swept into the HVAC exhaust stream and exhausted after passing through the facility HEPA filters. The HEPA filter operability will be verified before all fuel handling operations.

No industry standards exist for maximum allowable concentrations of uranium release as a result of an accident. For risk assessment purposes, a conservative criterion of accident concentrations at or below the accepted occupational levels was chosen (see Appendix $C$ ). Meeting this criterion is possible with only one stage of HEPA filtration. Because the occupational concentrations are chosen to protect personnel working under continuous exposures at these levels and because the release would be very short in duration, the consequence to the offsite population would be negligible.

\subsubsection{Irradiated Fuel Handling Accident Following Cooldown}

Following power operation, the fuel will remain in the reactor vessel for a period to allow for a decrease in the decay heat load. Then it will be cleaned of residual lithium. Following disassembly, the fuel will be transported from the 309 Building containment in an appropriate shipping cask. During core handling, while the nuclear materials are being removed from the vacuum vessel and loaded into the shipping container, confinement capability will be maintained. Handling and lifting operations will be carefully controlled by procedure; however, failure of equipment or procedure is credible. The postulated accident (which bounds the range of credible post-irradiation fuel handling accidents) is initiated by a major crane failure. The resulting load drop significantly damages the core with breach of the fuel cladding, fracturing of the fuel, and release of respirable uranium nitride fuel particles, noble gases, and other fission products into the containment 
atmosphere. It is further assumed that the radioactive gas and particles are swept into the HVAC exhaust stream and exhausted after passing through the facility HEPA filters.

Potential individual and population doses were calculated for this extremely unlikely event. The population dose was based on 1990 population projections. With provision of dual-stage HEPA filtration on the exhaust stream, the calculated offsite (public) maximum individual whole body dose is $4.8 \times 10^{-4}$ rem and the calculated onsite (worker) individual whole body dose is $4.2 \times 10^{-3}$ rem. The corresponding calculated whole body population dose commitment is 0.17 person-rem, which equates (applying risk factors discussed in Appendix A) to an increased potential for a latent cancer fatality from $1 \times 10^{-5}$ to $1 \times 10^{-4}$.

These maximum individual doses compare favorably with 10 CFR 100 Site Suitability criteria which specify that any individual on the outer site boundary should not receive a total radiation dose to the whole body in excess of 25 rem. (5.13) For health effect comparison, the local natural background radiation rate of 100 mrem per year for a population of 327,000 exposed for $50 \mathrm{yr}$ would have an estimated health effect of 82 to 820 radiation-induced cancer fatalities.

\subsubsection{Accidental Tritium Release}

Tritium retention will be provided by the Tritium Removal System (see Section 3.1.3.6.2). Tritium canisters will be periodically removed when the inventory reaches $1800 \mathrm{Ci}$. The system will be designed to be high integrity; however, a total release of the maximum inventory in the 309 Building was evaluated. This might occur if the tritium gettering system were involved in a fire and if downstream monitoring and holdup systems failed. Design provisions will be made to ensure that such a gaseous (including water vapor) release is extremely unlikely. 
Potential individual and population doses were calculated. The population dose was based on 1990 population projections. The calculated offsite maximum individual whole body dose is 0.22 rem, and the calculated onsite individual whole body dose is 2 rem. The corresponding whole body population calculated dose commitment is 5.6 person-rems, which equates (applying risk factors discussed in Appendix A) to an increased potential for a latent cancer fatality from $3 \times 10^{-4}$ to $3 \times 10^{-3}$.

Releases and spills of hazardous materials must be reported. Remedial actions will be taken, as necessary. All accidental releases will be evaluated to determine whether reportable spill quantities are involved. Full reporting, in compliance with applicable Comprehensive Environmental Response, Compensation, and Liability Act of 1980 (CERCLA), RCRA, and WAC regulations (see Section 7.7 and 7.8 ), will be provided.

\subsubsection{Secondary Coolant System Sodium Leak and Fire}

The sodium in the Secondary Heat Transport System can be expected to contain activated sodium and activated corrosion products. The combustion products of sodium are oxides and hydroxides of sodium. These particulates would have an adverse environmental impact, if released. The potential for release will be limited by a number of design features. Sodium piping will be built to high-quality standards, will be wrapped in insulation, will be provided with leak detection, will be located in enclosed pipeways or DHXs that will be isolable, will have associated catch pans to contain spills, and will have the capability to limit the leak magnitude by drain, if necessary. Liquid metal catch pans, possibly combined with inert gas purges, allow for extinguishing fires before a significant fraction of the inventory is con-sumed. Hanford operators and firefighters are trained for and experienced in fighting liquid metal fires; even with failure of engineered safety features, rapid extinguishing of potential fires would be expected. The assumed leak (Appendix $C$ ) of $500 \mathrm{gal}$ is the maximum credible spill because it represents the leakage of all sodium outside containment and bounds all other credible alkali metal leaks; a leak of this magnitude is extremely unlikely. 
Potential individual and population doses were calculated. The population dose was based on 1990 population projections. The calculated offsite maximum individual whole body dose is 0.021 rem and the calculated onsite individual maximum whole body dose is 0.19 rem. The corresponding whole body population calculated dose commitment is 0.53 person-rem, which equates (applying risk factors discussed in Appendix A) to an increased potential for a latent cancer fatality from $3 \times 10^{-5}$ to $3 \times 10^{-4}$.

The resulting alkali metal aerosol concentrations were also assessed. Use of conservative assumptions resulted in an aerosol concentration at the site boundary of $\sim 7 \mathrm{mg} / \mathrm{m}^{3}$ and an aerosol concentration onsite of about $64 \mathrm{mg} / \mathrm{m}^{3}$ for about 8 hours. The criterion for alkali metal aerosol concentrations during extremely unlikely events is $40 \mathrm{mg} / \mathrm{m}^{3}$ at the site boundary and $200 \mathrm{mg} / \mathrm{m}^{3}$ onsite (as developed in Appendix C).

Releases and spills of hazardous substances must be reported under CERCLA, RCRA, and WAC regulations (see Sections 7.5, 7.7, 7.8, and 7.9). Sodium leaks, if they should happen, would occur in areas that provide extensive protection against release to the environment. However, all accident releases will be evaluated to determine whether reportable spill quantities are involved. Full reporting, in compliance with CERCLA, RCRA, and WAC will be provided.

\subsubsection{Lithium Leak}

The toxicological effects of primary coolant lithium fires will be unlikely by design and would normally be enveloped by the effects of the accident discussed in Section 5.1.4.4. Radiological effects will be bounded by analyses in Section 5.1.4.2. An evaluation of the toxicological consequences of a lithium burn occurring during lithium drum unloading and primary system fill was performed to gain insight into the credible release levels and effects. For all credible scenarios, the alkali metal aerosol concentrations were well below the alkali metal aerosol concentration criteria (see Section 5.1.4.4). No public or environmental impact is anticipated from a lithium metal burn. Onsite recovery can be easily accomplished by neutralization of residue with 
an acidic wash and by cleanup of the affected area. Onsite personnel will use protective gear if work in close proximity with liquid metal is required; minimal risk to onsite personnel is expected.

Releases and spills of hazardous materials must be reported under CERCLA, RCRA, and WAC regulations (see Sections 7.5, 7.7, 7.8, and 7.9). Lithium leaks, if they should happen, will occur in areas that provide protection against release to the environment. However, all accident releases will be evaluated to determine whether reportable release or spill quantities are involved. Full reporting, in compliance with CERCLA, will be provided.

\subsubsection{Consequences of a Severe Reactor Accident}

In order to provide a perspective of the bounding consequences associated with the SP-100 GES Test Site reactor test, an accident scenario was developed in this section that goes beyond the Design Basis Accidents considered in Section 5.1.4. The discussion presented in this section is not an indication that a severe accident will ever occur. Rather, this approach attempts to place in perspective the bounding consequences associated with severe accidents of sufficiently low probability of occurrence that they are not included in the design basis. Detailed probabilistic data for equipment failure, etc., from which accident likelihood could be developed are not available at this stage of the project design; however, the sequence of events presented will be highly unlikely, based on design and operations measures taken. The SP-100 facility, systems, and components will be designed to handle and withstand Design Basis Accidents including effects of natural phenomena.

The severe reactor accident represents an extreme scenario that postulates gross degradation of engineered safety features and takes no credit for short-term emergency response actions. Examples of system failures that were assumed to reach these severe accident consequences include failure of the primary reactor coolant boundary with substantial loss of coolant, failure of emergency core cooling, failure of the core to maintain structural integrity, relocation of the core to provide a high energy recriticality, 
failure of the vacuum vessel, and a concurrent nonmechanistic failure of containment by malfunction of the H\&V containment isolation exhaust valve.

Other mechanistic failure sequences were identified as candidates for inclusion in a severe accident analysis. None of the scenarios considered were more challenging than the selected scenario, and all of these scenarios would result in lower consequences than those documented here.

The evaluations presented in this section include a mixture of nominal and conservative evaluations with the goal to provide bounding consequences. Where possible, nominal analyses were used to allow realistic consequence assessments. When specific data were not readily available, conservative projections were made.

If this severe accident were to occur, for the Hanford Site boundary individual, the maximum whole-body dose would be $0.75 \mathrm{rem}$. This amounts to a single exposure dose for that individual of 7.5 times that of the annual background dose of $100 \mathrm{mrem}$; no acute health effects would result. The offsite latent cancer fatality risk per accident resulting from all whole-body doses for a severe accident would be less than $6.0 \times 10^{-3}$ fatalities.

Onsite (worker) whole-body doses would not exceed 3.4 rem. Actual doses would be expected to be lower because of operator response and onsite personnel evacuation. No acute effects result from such radiation exposures.

\subsection{SOCIOECONOMIC EFFECTS OF THE PROPOSED ACTION}

This section covers the effects on the community that result from adopting the proposed action. The proposed action would not involve use of additional 1 and or facilities.

No immigration into the region is expected from GES construction or operations at the proposed site. The estimated peak work force for the project is less than 230 people. The permanent GES work force would make up less than $1 \%$ of both the local area's total employment (about 75,000 ) and the 
Hanford Site's employment (about 12,000). The proposed action could benefit the community by helping to maintain employment levels and availability of skilled labor at the Hanford Site.

\subsection{DECONTAMINATION AND DECOMMISSIONING}

Following completion of the SP-100 GES Test, the reactor fuel, test reactor, and systems inside the vacuum vessel will be removed. Test facility systems external to the vacuum vessel will be put in a safe condition pending future use or ultimate decommissioning. The remainder of the 309 Building will be available for future projects.

Following posttest examination, the test article will be disposed of as low-level waste at Hanford. If possible, the enriched fuel materials will be recycled using the Idaho Chemical Processing Plant. If recycling is not possible, the materials will be handled as transuranic (TRU) waste and will be packaged following site standards. Ultimate disposal will be accomplished by use of the Waste Isolation Pilot Plant disposal facilities.

No significant airborne or liquid effluents will result from the decontamination and decommissioning process. The environmental impacts of this process will be limited to disposal of waste materials as discussed in Section 5.1.2.

\subsection{RELATIONSHIP OF PROPOSED ACTION TO LAND-USE PLANS}

Construction and operation of the GES Test at the Hanford Site will not conflict with national, state, or local land-use plans or policies. The 309 Building was previously used for nuclear reactor research. Thus, the GES Test mission is consistent with past facility use. In addition, Hanford Site 1 and is dedicated to nuclear research and production and supporting activities. 
A11 land use is, and will continue to be, managed in conformance with appropriate federal and state regulations (see Section 7.0 ) to ensure the safety of the public. The proposed or alternative action will be undertaken on previously disturbed 1 and and will not affect any archeological sites.

\subsection{IRREVERSIBLE AND IRRETRIEVABLE COMMITMENTS OF RESOURCES}

Irreversible and irretrievable commitments of resources for the GES Test include materials for both construction and operations.

The GES Test will use about $700 \mathrm{~kg}(1543 \mathrm{lb})$ of niobium, a strategic metal. Some test reactor components will be constructed of $99 \%$ niobium and $1 \%$ zirconium.

Niobium is an essential element in superalloys used in jet and turbine engines. ${ }^{(5.14)}$ It is also broadly used as an alloying element in certain specialty steels.

The U.S. uses about one-fourth of the world's production of niobium. There is no significant domestic source although the U.S. contains about $363 \mathrm{million} \mathrm{kg}$ ( $800 \mathrm{million} \mathrm{lb}$ ) of low-grade niobium ore. The U.S. reserves are also negligible, and recycling is currently insignificant. Thus, the U.S. relies essentially on imports.

World resources are considered more than adequate to supply projected GES Test needs. World production of niobium in 1984 totaled about 10.4 million $\mathrm{kg}(23$ million $\mathrm{lb})$. World reserves are estimated at 4.2 billion $\mathrm{kg}(9.2$ billion $1 \mathrm{~b})$. World resources total about 17.2 billion $\mathrm{kg}$ (38 billion $\mathrm{lb})$, with the largest amount in Brazil. (5.14)

Other uncommon (but nonstrategic) materials that will be used include lithium-7 and beryllium. Less than $150 \mathrm{~kg}(330 \mathrm{lb})$ of lithium-7 will be used in the reactor coolant system, and about $100 \mathrm{~kg}(220 \mathrm{lb})$ of beryllium will be used for reflectors.

No additional strategic materials will be necessary for the Hanford Site at the 300 Area location. 
6.0 RADIOLOGICAL RISK ASSESSMENT OF POTENTIAL SP-100 USE IN SPACE

$6.1 \quad$ INTRODUCTION

The technology being developed during the SP-100 GES Program will make possible a broad class of emerging military and civil space missions. Several conceptual space missions, using the SP-100 space reactor power system (SRPS) as a source of electrical power are being considered at this time. However, no specific space mission has been identified. While the DOE will not be the "user" agency for a space mission, it will play a major role in the design, development, and test of the flight unit. The DOE will also be responsible for performing the detailed safety analysis of all phases of the proposed mission and preparing a Final Safety Analysis Report that will be required to obtain approval for the mission. When a federal agency (NASA or DOD) commits to a specific mission, that agency will be responsible for preparing environmental documentation for the mission. The environmental documentation will address all significant environmental impacts, of which Radiological Impacts is one category.

At this stage of the SP-100 GES technology program, specific flight system design and mission parameters are not available. For example, the SRPS power requirements (tens to hundreds of kilowatts), the operating altitude, the launch site (Kennedy or Vandenberg), and the launch vehicle (shuttle or expendable) are not known at this time. Since a specific mission has not been selected, a detailed environmental assessment evaluating potential impacts is impossible. However, it is possible to assess some reasonably forseeable missions and potential accident scenarios at this time to provide insight into potential radiological consequences of future space deployment of SP-100 reactors. Therefore, the SP-100 Program has conducted a radiological risk assessment of possible future missions to ensure that the technology development efforts are directed towards reducing potential radiological impacts. (6.1) Because potential radiological impacts from reactor use are the only factors that distinguish a SRPS mission from previous space flights, other potential environmental impacts were not assessed. 
Three hypothetical missions representative of the range of missions(6.2) for which SP-100 is applicable were analyzed:

- A TITAN-launched high-orbit surveillance or communications mission

- A shuttle-launched Nuclear Electric Propulsion (NEP) mission to explore Neptune

- A shuttle-launched low-orbit surveillance or communications mission.

The risk assessment results, described in this section, are based on the analytical approach used for the safety analyses of past and current space missions employing nuclear power sources. Using hypothetical mission scenarios and the latest SP-100 design information, accident scenarios and associated probabilities were generated, source terms were defined, and the dispersion and time behavior of released radioactivity were analyzed. Environmental exposure pathways were identified and potential radiological impacts were evaluated in terms of potential population doses and associated heaith effects. $(6.1)$

Section 6.2 describes the safety review inherent in the SP-100 design process and Section 6.3 describes the major safety features that have been incorporated in the SP-100 design to minimize radiological risk. Section 6.4 presents the analytical approach used in the risk assessment, and Section 6.5 presents the results and conclusions of the assessment.

\subsection{SAFETY PROCESS}

Every nuclear power system that is considered for use in a space application by the United States undergoes a comprehensive safety review to identify and characterize the risks posed and the benefits to be derived from its use. $A$ formal review process that was first established in the 1960s is used for this purpose. At the center of this process is the Interagency Nuclear Safety Review Panel. The panel is chaired by three appointees, one each from DOD, NASA, and DOE. The panel has its own independent staff of technical experts. Its Safety Evaluation Report is forwarded to the Office of Science 
and Technology Policy, with the Office of the President, along with the user agency's request for launch approval. The final launch decision is made by the Director of the Office of Science and Technology Policy or by the President. As part of this review process, the Preliminary, Updated, and Final Safety Analysis Reports are prepared, supported by actual system and component designs whose performances have been validated by tests and analysis.

The SP-100 SRPS is being designed to obtain eventual launch approval. The design process $(6.3)$ is structured to ensure the ongoing consideration and independent review of safety throughout all aspects of the design, fabrication, testing, and ultimately, the use of the reactor power system. At the outset, safety requirements were established in Technical Specifications, and the system must meet these requirements. (6.1) Engineering analyses and reviews are performed to identify and eliminate or mitigate the effects of potential hazards. Assessments are used for safety design confirmation and quantification of risks. Results of these analyses and tests provide important design feedback so that the design can be modified to enhance its safety and reduce risk. Finally, extensive and independent reviews are conducted to ensure that the final design meets all safety requirements.

\subsection{SAFETY FEATURES}

Five major safety features have been incorporated into the SP-100 design to minimize radiological risk.

\subsubsection{Safety of Unirradiated 235 U Fue 1}

The SP-100 fuel was chosen to be uranium nitride highly enriched in isotope $235 \mathrm{U}$. Since the reactor will not be operated prior to launch, except for some very low-power qualification tests, the fuel will not present a radiological hazard during launch. Even if some fuel is dispersed in a major launch accident, the fuel will not contribute to a health risk because no radioactive fission products will have been generated. 


\subsubsection{Ensured Shutdown in Accident Scenarios}

The SP-100 reactor is designed to remain subcritical when subjected to a wide range of accident scenarios, including water immersion and flooding, burial, and launch explosions. The internal neutron absorber rods, rhenium fuel cladding liners, and the neutron barrier around the core prevent the reactor from going critical in the case of water flooding. Internal neutron absorber rods with mechanical latches are provided to preclude their removal during blast or impact scenarios. A honeycomb reactor internal structure will restrain movement of the fuel rods in the case of blast or impact.

\subsubsection{Diverse and Redundant Shutdown Mechanisms}

The SP-100 Reactor Control and Instrumentation Subsystem is designed to reliably shut down the reactor in the event of a number of potentially serious off-normal conditions (i.e., overtemperature, loss of coolant, loss of altitude or attitude control, and extended loss of communications). Redundant, autonomous onboard controllers provide protection if communication with the ground is lost temporarily. Diverse and redundant instrumentation and sensors are provided to ensure a highly reliable control system.

\subsubsection{Intact Reentry and Impact}

It is a Program objective that the SRPS be designed and operated such that planned reentry into the earth's atmosphere after deployment in space will not occur. However, the SRPS shall be designed to safely accommodate reentry as an anomalous mission occurrence as an additional precaution. To ensure intact reentry and impact for postulated accidental reentry, a carbon/carbon-composite reentry nose cone has been incorporated in the design. The reentry cone maintains the reactor vessel temperature sufficiently low so that structural integrity and configuration is not impaired. Also, the lithium coolant in the core remains below its melting temperature, adding to the resiliency of the core upon impact. 


\subsubsection{Loss-of-Coolant Accident Protection}

For some orbital missions, the existing and anticipated space debris fields increase the likelihood of an in-orbit impact that could initiate a loss of reactor coolant. To provide mitigation for these low probability accidents, an independent auxiliary coolant loop is incorporated in the design to maintain fuel rod temperatures below those at which any significant cladding damage and fuel or fission product release could occur. In this way the basic structural integrity and configuration of the reactor would be maintained, and the capability for postmission disposal would not be compromised.

\section{$6.4 \quad$ ANALYTICAL APPROACH}

The analytical approach used to perform the risk assessments is based on the accepted analytical approach used for safety analyses of past and current space missions employing nuclear power sources [e.g., SNAPSHOT (SNAPIOA reactor in 1965), Voyager (MHW-RTG in 1977), and Galileo (GPHS-RTG) to be 1 aunched in the near future) $]^{(6.1)}$. This approach is also consistent with a recent U.S. Department of Transportation report entitled, "Hazard Analys is of Commercial Space Transportation." (6.4) Based on the assumed hypothetical mission scenarios and the latest SP-100 generic design information (see Section 6.1), accident scenarios and associated probabilities were generated and presented as mission event tree summaries.

An event tree summary for the three hypothetical missions is presented in Table 6.1. The different failure modes are grouped together according to their possible consequences. There can be multiple failure modes for each phase of the mission. For example, accident events during the Shuttle Ascent/Deployment Phase include tipover, tumbling, explosion, or fire resulting from failures in the Solid Rocket Boosters (SRB) or in the Space Shuttle Main Engines (SSME). However, all these failures can have similar possible consequences: reactor criticality, fuel dispersal from a reactor damaged by fire or impact, or no fuel release from an intact reactor.

Accident and failure probabilities used in this analysis were grouped into two classes: those associated with the launch vehicle and those associated 
TABLE 6.1

MISSION EVENT TREE SUMMARY -- SP-100 SPACE REACTOR POWER SYSTEM MISSION HAZARDS

\begin{tabular}{|c|c|c|c|c|c|c|c|c|}
\hline \multirow[b]{2}{*}{ Mission Phase } & \multicolumn{4}{|c|}{ Failure Modes } & \multicolumn{4}{|c|}{ Consequences } \\
\hline & $\begin{array}{l}\text { Launch } \\
\text { Vehicle } \\
\text { or Boost } \\
\text { Malfunction } \\
\end{array}$ & $\begin{array}{c}\text { Failure } \\
\text { to Start } \\
\text { Reactor or } \\
\text { Early Shutdown }\end{array}$ & $\begin{array}{l}\text { Failure } \\
\text { to Shut } \\
\text { Down }\end{array}$ & $\begin{array}{c}\text { Debris } \\
\text { Hit } \\
\text { In-Orbit }\end{array}$ & $\begin{array}{c}\text { Breakup } \\
\text { and } \\
\text { Reentry } \\
\text { Dispersal }\end{array}$ & $\begin{array}{c}\text { Minor } \\
\text { Reactor } \\
\text { Damage } \\
\end{array}$ & $\begin{array}{l}\text { Critical } \\
\text { Configuration } \\
\text { Nuclear Excursion } \\
\text { and Disassembly }\end{array}$ & $\begin{array}{c}\text { Earth } \\
\text { Impact of } \\
\text { Operating } \\
\text { Reactor } \\
\end{array}$ \\
\hline $\begin{array}{l}\text { 1. TITAN-Launched High- } \\
\text { Orbit Mission } \\
\text { Prelaunch/Launch } \\
\text { Ascent/Deployment } \\
\text { High Orbit Operation } \\
\text { 2. Shuttle-Launched } \\
\text { NEP Mission } \\
\text { Prelaunch/Launch } \\
\text { Ascent/Deployment } \\
\text { NEP Operation } \\
\text { 3. Shuttle-Launched } \\
\text { Low-Orbit Mission } \\
\text { Prelaunch/Launch } \\
\text { Ascent/Deployment } \\
\text { Low-Orbit Operation } \\
\text { Post-Operation } \\
\text { Disposal }\end{array}$ & $\begin{array}{l}x \\
x \\
x\end{array}$ & $\begin{array}{l}x \\
x\end{array}$ & $x$ & $\begin{array}{l}x \\
x\end{array}$ & $\begin{array}{l}x \\
x \\
x\end{array}$ & $\begin{array}{l}x \\
x \\
x \\
x\end{array}$ & $\begin{array}{l}x \\
x \\
x\end{array}$ & $x$ \\
\hline
\end{tabular}

$x=$ Event possible in mission phase. 
with the performance of the SP-100 SRPS. For the two missions using the space shuttle, the launch accident probability estimates are the same as those used in the Space Shuttle Data for Planetary Mission Radioisotope Thermoelectric Generator Safety Analys is (NSTS $08116 \mathrm{Rev.} \mathrm{A)} \mathrm{for} \mathrm{the}$ forthcoming Galileo mission. ${ }^{(6.5)}$ For the TITAN-Iaunched mission, the launch accident probabilities were taken from the TITAN IV Radioisotope Thermoelectric Generation Safety Databook (6.1). Thus, the launch vehicle accident probabilities used in the radiological risk assessment were consistent with the latest safety analysis and risk assessments for missions using nuclear power sources. The probabilities used to describe the functional performance of the SP-100 SRPS are summarized in Table 6.2. Because the current generic SP-100 design is for demonstrating the adequacy of the technology during this phase of the program, and since little hard data on hardware reliability performance yet exist, best-estimate failure probabilities were derived from a mixture of design goals, preliminary engineering estimates based on performance of past similar components, and preliminary design calculations.

For each summary accident sequence, radiological source terms, as shown in Table 6.3, were identified by the type of accident and the reactor operating history prior to the accident. Source term types $A$ through $C$ are derived for previously unfissioned fuel while source term types $D$ through $G$ are derived for previously fissioned fuel.

The inventory of radionuclides available as a function of time was then calculated. Evaluation of the radiological impact of postulated scenarios involving fuel and fission product releases into the environment included the following steps:

1. Identification of postulated accident release modes, including the probability and location of a release

2. Definition of source term, including the amount of each radionuclide released and the corresponding chemical form and particle size distribution

3. Analysis of dispersion and time behavior of the released radioactivity to determine the concentrations in air, soil, and water as a function of time 
TABLE 6.2

SP-100 FAILURE PROBABILITIES ASSUMED FOR RISK ANALYSIS(6.1)

Event

Failure to Start Reactor**

Failure to Shut Reactor Down**
Conditional*

Probability

0.001

$10^{-6}$
Basis

Reliable design, checked before launch and deployment.

Diverse and redundant control, only a few control elements needed, negative reactivity from LOCA.

Reactor slowly shuts down by reactivity depletion after full-power operation.

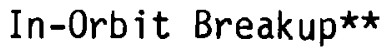

Nuclear Electric Propulsion

$10^{-6}$

Short time in debris field.

During Orbital Operation or Reentry

Minor Damage to Reactor as a

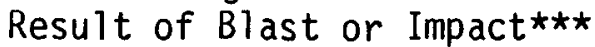

Nuclear Excursion and

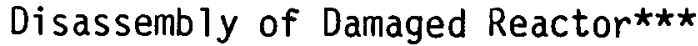

0.0001 Time-weighted probability of

0.01 damage from debris hit.

Rugged design, results of preliminary calculation.

0.0001 Large shutdown margin, design calculations, experiments, mechanical latches.

\footnotetext{
*Conditional: Subject to the condition that a previous event has occurred. $\star \star$ Failure modes from Table 6.1 .

$\star \star \star$ Consequences from Table 6.1 .
} 
TABLE 6.3

REACTOR SOURCE TERM TYPES AND RELEASE FRACTIONS(6.1)

Accident

Land or Ocean Impact

Minor Reactor Damage in Subcritical

Configuration

Critical Configuration

(Nuclear Excursion and Disassembly)

Earth Impact of Operating Reactor
Unfissioned Fuel

Fissioned Fuel
Type A

1\% fuel particulates

Type B

$100 \mathrm{MW}-\mathrm{s}$ excursion $100 \%$ noble gases

$25 \%$ volatiles

$10 \%$ particulates

Not applicable
Type D

Same as Type A plus $3 \%$ noble gases

$3 \%$ volatiles

Type E

Same as Type B plus

same fractions

of accumulated

fission products inventory

\section{Type $F$}

Same as Type E plus fission product inventory per operating history

High-Altitude Release and Footprint on

Land or Ocean

Breakup and

Reentry Dispersal
Type $\mathrm{C}$

$90 \%$ debris

$10 \%$ fuel vapor

$10 \%$ particulates
Type $G$

Same as Type C plus

$10 \%$ noble gases

$10 \%$ halogens

$10 \%$ volatiles 
4. Analysis of ingestion, inhalation, and external radiological doses through each environmental exposure pathway

5. Evaluation of radiological impact in terms of the population doses received and the resulting health effects.

Environmental radionuclide concentrations have been calculated as a function of time for the following type of releases:

- High-altitude vapor releases

- High-altitude particulate releases

- Low-altitude (including ground leve1) releases

- Aquatic releases.

\subsection{SUMMARY OF RESULTS}

The results of the risk analysis of potential SP-100 missions are presented in Table 6.4. It can be seen that for the three missions, the risk contributions from all phases prior to reactor operation are negligibly low because, prior to operation, the SP-100 reactor contains on the order of only $15 \mathrm{Ci}$ of radionuclides. The more significant risk contributors vary from mission to mission but, in all cases, are quite low.

Using the conservative BEIR III (6.6) linear dose response model, the expectations of radiological health effects, expressed as latent fatalities statistically expected per mission, are calculated to be:

- TITAN-Launched High-Orbit Mission v 0.00007

- Shuttle-Launched NEP Mission 0.00006

- Shuttle-Launched Low-Orbit Mission 0.00036 .

These results include the health effects of possible operational and accident scenarios that result in dispersed fuel and fission products and, in some instances, direct dose from a previously operated intact reactor. These very low expected health effects clearly indicate that future SP-100 missions can be designed and conducted so as to present a low risk to the public and the environment. See Appendix, Section A.2 for discussion of Radiologically Related Health Effects. 
TABLE 6.4

SP-100 MISSION HEALTH EFFECTS SUMMARY

FOR POSTULATED ACCIDENT SCENARIOS

\section{Mission Phase}

1. TITAN-Launched HighOrbit Mission

$$
\begin{aligned}
& \text { Prelaunch/Launch* } \\
& \text { Ascent/Deployment* } \\
& \text { High Orbit Operation }
\end{aligned}
$$

Total Mission

2. Shuttle-Launched Nuclear

Electric Proputsion Mission

Prelaunch/Launch*

Ascent/Deployment*

Nuclear Electric

Propulsion Operation

Total Mission
Probability of

Population Dose
Statistica 1

Expected Total

Population Dose

(person-rem)
8. $5 E-06$
3. $1 E-03$
$5.2 E-05$
$1.0 \mathrm{E}-03$
$3.2 E-01$
$5.8 \mathrm{E}-01$
3. 2E-01
5.9E-01

1.8E-06

3. $2 E-04$

$9.7 E-03$

$1.0 E-02$
5.1E-01

6.7E-04

$2.6 \mathrm{E}-03$

5. $1 E-01$

3. Shuttle Low-Orbit Mission

\author{
Prelaunch/Launch* \\ Ascent/Dep loyment* \\ Low-Orbit Operation \\ Postoperation Disposal \\ Total Mission
}

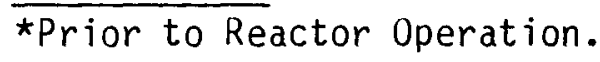

1. $8 E-06$

8. $1 E-04$

2. $9 E-03$

2. $8 \mathrm{E}-04$

4. $0 E-03$
6.7E-04

3. $9 E-03$

2.8

1. 1E-01

3.0 
7.0 PERTINENT LAWS, REGULATIONS, AND GUIDELINES

This section lists the more significant laws, regulations, and guidelines relevant to the proposed GES Test Site activities for occupational and public radiation exposure; air quality; liquid, gaseous, and particulate emissions from facilities; and handling and disposal of hazardous wastes. Operation of the GES Test will be consistent with all these laws, regulations, and guidelines. State permits for radionuclide emissions will be obtained as required.

7.1 DOE Order 5480.1A, "Environmental Protection, Safety, and Health Protection Programs for DOE Operations," Chapter XI, "Requirements for Radiation Protection" (as supplemented)

Chapter XI of this order establishes radiation protection standards and requirements for the DOE and DOE contractors. It establishes radiation protection standards for occupationally related external and internal exposure and for exposure to members of the public in uncontrolled areas. It also provides guidance on maintaining exposures to radiation at levels as low as reasonably achievable (ALARA).

This order has recently been supplemented by adopting revised International Commission on Radiological Protection (ICRP) recommendations on radiation standards (see Appendix F). The interim standards, effective July 1, 1985, limit the continuous dose to any member of the public to $100 \mathrm{mrem} / \mathrm{yr}$ resulting from all routine DOE operations at a DOE site. From the air pathway alone, the limit for whole-body dose is $25 \mathrm{mrem} / \mathrm{yr}$ (in accordance with 40 CFR 61 , Subpart H).(7.1) The main text of this order is undergoing revision; however, no significant revision to the standards for protection of the public is anticipated.

7.2 Code of Federal Regulations, 40 CFR 50, "National Primary and Secondary Ambient Air Quality Standards"

This regulation (7.2) provides national air quality standards. National primary ambient air quality standards define those levels that the Environmental Protection Agency (EPA) judges as necessary to protect public health. 
7.3 Code of Federal Regulations, 40 CFR 61, "National Emission

These regulations $(7.1)$ provide air emission standards for beryllium, mercury, asbestos, vinyl chloride, and other hazardous materials. 40 CFR 61.92 establishes limits for annual radiation doses to members of the general public resulting from air emissions from DOE activities at a DOE site. These annual limits are 25 mrems to the whole body, 75 mrems to the thyroid, and 25 mrems to any other organ.

\subsection{Code of Federal Regulations, 40 CFR 141, "National Drinking Water Regulations"}

These regulations (7.3) implement the Public Health Service Act, as amended, and establish standards applicable to public water systems. The EPA administers these regulations and establishes radioactivity levels in community water systems (those defined as water systems that have at least 15 year-round service connections or regularly serve at least 25 residents). No community water system exists adjacent to or on the Hanford Site. The first community water system downstream from the Hanford Site is the municipal water plant for Richland, Washington. This plant draws water from the Columbia River.

These regulations specify that the average annual concentration of man-made beta and gamma-emitting radionuclides in water supplied by a community drinking system shall not deliver an annual dose-equivalent greater than $4 \mathrm{mrem} / \mathrm{yr}$ per person to the whole body or any internal organ. Gross alpha activity shall not exceed $15 \rho \mathrm{Ci} / \ell$.

7.5 Code of Federal Regulations, 40 CFR 260-268, "Resource Conservation

These regulations (7.4-7.10) implement the Resource Conservation and Recovery Act of 1976 (RCRA), which was amended and reauthorized in 1984. The EPA and the state (see Section 7.8) administer these regulations, which define various types of hazardous wastes and specify how the various types must be transported, handled, and disposed. 
Activities associated with the test will result in limited generation of hazardous waste (as discussed in Sections 5.1.2 and 5.1.3). Such wastes will be treated, stored, and disposed of in accordance with the applicable requirements of RCRA, in particular 40 CFR 268 (Land Disposal Restrictions).

7.6 Washington Administrative Code, Title 18, Chapter 173-400, "Washington State Air Pollution Control Regulations" and General Regulation 80-7 of the Benton-Franklin-Walla Walla Air Pollution Control Authority

These regulations $(7.11)$ provide air quality standards to obtain and maintain the cleanest air reasonably possible (consistent with practicable control technology). Included are standards for suspended particles, fluorides, sulfur oxides, carbon monoxide, ozone, and nitrogen dioxide.

7.7 Code of Federal Regulations, 40 CFR 302, "Designation, Reportable
Quantities, and Notification"

These regulations implement the Comprehensive Environmental Response, Compensation, and Liability Act of 1980 (CERCLA). The EPA administers these regulations that identify reportable spill quantities and establish notification and handling requirements for these materials.

7.8 Washington Administrative Code, Title 18, Chapter 173-303, "Washington State Dangerous Waste Regulations"

The Washington State Department of Ecology regulations, (7.12) as amended in 1984, define hazardous wastes and cover handling, transportation, and disposal, as outlined in Revised Code of Washington (RCW) 19.114 and 70.105. Most of the regulations in WAC Chapter 173-303 are identical to 40 CFR 260-265, but a few are stricter. WAC Chapter 173-303 addresses transportation of hazardous wastes by directing the generator to U.S. Department of Transportation regulations 49 CFR 172, 173, 178, and 179. (7.13) 
The EPA has authorized the State of Washington to administer the hazardous and mixed nonradioactive hazardous waste generation, treatment, storage, and disposal pursuant to the RCRA, except for certain requirements established by the 1984 amendments to RCRA, which will remain the responsibility of the EPA.

Activities associated with the SP-100 GES Test operation and decommissioning will result in limited generation of hazardous wastes (as discussed in Sections 5.1.2 and 5.1.3). Such wastes will be treated, stored, and disposed of in accordance with the applicable requirements of RCRA and the applicable sections of the Washington Administrative Code.

7.9 Washington Administrative Code, Title 18, Chapter 173-480, "Ambient Air Quality Standards and Emission Limits for Radionuclides" and WAC Chapter 402-80, "Monitoring and Enforcement of Air Quality and Emission Standards for Radionuclides"

The WAC 173-480 standards provide that emissions of radionuclides to the air shall not cause a dose equivalent of more than $25 \mathrm{mrem} / \mathrm{yr}$ to the whole body or $75 \mathrm{mrem} / \mathrm{yr}$ to a critical organ of any member of the public, the same criteria as those in 40 CFR 61.92.(7.14) In addition, all emissions are required to meet ALARA requirements, and new or modified units shall use the best available radionuclide control technology. Registration of emission sources and permit issuance is conducted by the Washington State Department of Social and Health Services in accordance with WAC 402-80.

7.10 Transportation Regulations

GES Test activities will involve offsite and onsite transportation of radioactive materials. Such transportation will be in accordance with applicable DOE Orders, including DOE Order 5480.3(7.15) and DOE-RL Order 5480.1 , Chapter III. $(7.16)$ 
8.0 AGENCIES CONSULTED

This Environmental Assessment was prepared, reviewed, and approved in accordance with DOE Order 5440.1C, "Implementation of the National

Environmental Policy Act."(8.1) No parties or agencies other than Program participants were consulted in the preparation of this Environmental Assessment. 
9.0 ACRONYMS, ABBREVIATIONS, AND CONVERSIONS

ACL Auxiliary Cooling Loop

ACS Auxiliary Cooling System

ALARA As Low as Reasonably Achievable

ALE Arid Land Ecology

Ar Argon

$\mathrm{Bq} \quad$ Bequerel $\left(1 \mathrm{~Bq}=2.7 \times 10^{-11} \mathrm{Ci}\right)$

C Carbon

CEQ Council on Environmental Quality

CFR Code of Federal Regulations

CG Concentration Guides

Ci Curie

CERCLA Comprehensive Environmental Response, Compensation, and Liability Act of 1980

Cs Cesium

Co Cobalt

CRT Cathode Ray Tube

DBE Design Basis Earthquake

DHX Dump Heat Exchanger

D\&D Decontamination and Decommissioning

DOD U.S. Department of Defense

DOE U.S. Department of Energy

DOE-RL U.S. Department of Energy-Richland Operations Office

EA Environmental Assessment

ECCS Emergency Core Cooling System

EHA Engine/Heat-Exchanger/Alternator

EIS Environmental Impact Statement

EM Electromagnetic

EPA U.S. Environmental Protection Agency

ERDA U.S. Energy Research and Development Administration

FCP Fuel Cycle Plant

FFTF Fast Flux Test Facility

FONSI Finding of No Significant Impact

FSAR Final Safety Analys is Report 


$\begin{array}{ll}\text { GES } & \text { Ground Engineering System } \\ \text { GPHS } & \text { General Purpose Heat Source } \\ \text { Gy } & \text { Gray (1 Gy = 100 rad) } \\ \text { HEDL } & \text { Hanford Engineering Development Laboratory } \\ \text { HEPA } & \text { High-Efficiency Particulate Air (Filter) } \\ \text { HTSF } & \text { High-Temperature Sodium Facility } \\ \text { HVAC } & \text { Heating, Ventilation, and Air Conditioning } \\ \text { I } & \text { Iodine } \\ \text { IAEA } & \text { International Atomic Energy Agency } \\ \text { IAT } & \text { Integrated Assembly Test } \\ \text { ICRP } & \text { International Commission on Radiological Protection } \\ \text { IHX } & \text { Intermediate Heat Exchanger } \\ \text { ILRT } & \text { Integrated Leak Rate Test } \\ \text { Kr } & \text { Krypton } \\ \text { LLW } & \text { Low-Level Waste } \\ \text { LOCA } & \text { Loss-of-Coolant Accident } \\ \text { mCI } & \text { milliCurie (10-3 Curie) } \\ \text { MHW } & \text { Multihundred-Watt } \\ \text { MM } & \text { Modified Mercalli (Earthquake Intensity Scale) } \\ \text { NaK } & \text { Sodium and Potassium (Eutectic Mixture) } \\ \text { NASA } & \text { National Aeronautics and Space Administration } \\ \text { NAT } & \text { Nuclear Assembly Test } \\ \text { NEP } & \text { Nuclear Electric Propulsion } \\ \text { NEPA } & \text { National Environmental Policy Act } \\ \text { Nb-l\%Zr } & \text { Alloy of Niobium and Zirconium } \\ \text { PCA } & \text { Power Conversion Assembly } \\ \text { PCC\&D } & \text { Power Conditioning, Control, and Distribution } \\ \text { PCDC } & \text { Prioritized Competing Design Characteristics } \\ \text { PGA } & \text { Peak Ground Acceleration } \\ \text { PNL } & \text { Pacific Northwest Laboratory } \\ \text { PRTR } & \text { Plutonium Recycle Test Reactor } \\ \text { PU } & \text { Plutonium } \\ \text { PSAR } & \text { Preliminary Safety Analysis Report } \\ \text { PUREX } & \text { Plutonium Uranium Extraction Facility } \\ \text { PWR } & \text { Power }\end{array}$




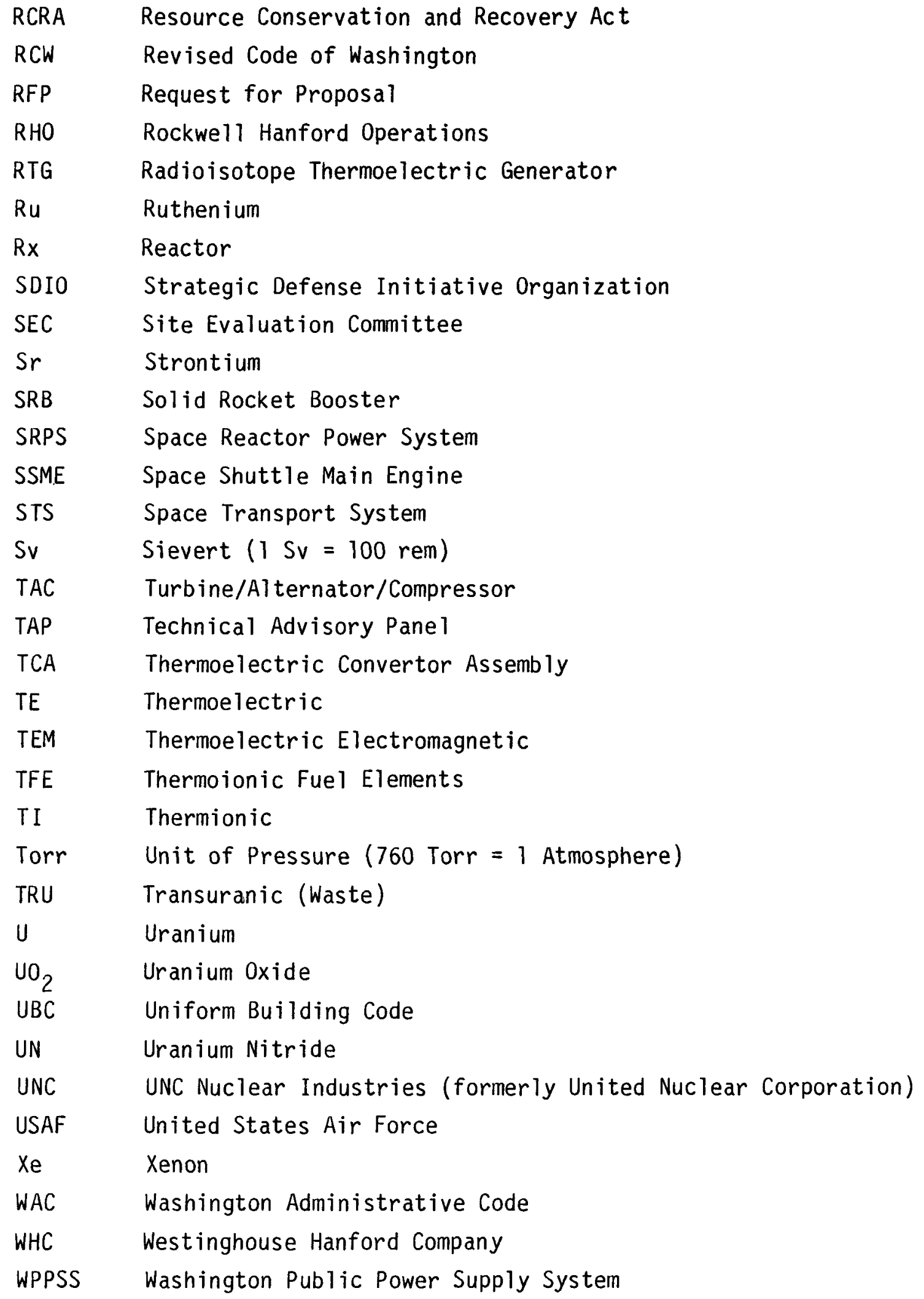


1.1 Code of Federal Regulations, "Regulations for Implementing the Procedural Provisions of the National Environmental Policy Act," 40 CFR 1500-1508, Council on Environmental Quality, U.S. Environmental Protection Agency, Washington, DC, November 28, 1978.

1.2 Federal Register, 52 FR 47662, December 15, 1987.

3.1 Uniform Building Code, International Conference of Building Officials, 1956 edition.

3.2 ASME Boiler and Pressure Vessel Code, American Society of Mechanical Engineers, New York, NY, 1956 edition.

3.3 ANSI/ANS Standard 56.8-1981, "Containment System Leakage Testing Requirements."

3.4 ANSI Standard N13.1-1969 (R1982), "Guide to Sampling Airborne Radioactive Materials in Nuclear Facilities."

3.5 DOE Order 5480.1A, "Environmental Protection, Safety, and Health Protection Program for DOE Operations, " Chapter XI, U.S. Department of Energy, Washington, DC, November 2, 1981.

3.6 DOE Order 5480.3, "Safety Requirements for the Packaging and Transportation of Hazardous Materials, Hazardous Substances, and Hazardous Wastes, "U.S. Department of Energy, Washington, DC, July $9,1985$.

4.1 J. D. Jamison, Standardized Input for Hanford Environmental Impact Statements, Part II: Site Description, PNL-3509, Pt 2, Pacific Northwest Laboratory, Richland, WA, 1982.

4.2 J. N. Paglieri, 300 Area Site Description, HEDL-TME 75-13, Hanford Engineering Development Laboratory, Richland, WA, 1975.

4.3 W. A. Stone, J. M. Thorp, 0. P. Gifford, and D. J. Hoitink, Climatological Summary for the Hanford Area, PNL-4622, Pacific Northwest Laboratory, Richland, WA, 1983.

4.4 Environmental Impact Statement - Operation of PUREX and Uranium 0xide Plant Facilities, D0E/EIS-0089, U.S. Department of Energy, Washington, DC, February 1983.

4.5 Draft Environmental Impact Statement, Process Facility Modifications Project, D0E/EIS-0115D, U.S. Department of Energy, Washington, DC, April T986. 
4.6 Draft Environmental Impact Statement, Disposal of Hanford Defense High-Level, Transuranic, and Tank Wastes, DOE/EIS-0113, U.S. Department of Energy, Washington, DC, 1986.

4.7 Final Environmental Statement Liquid Metal Fast Breeder Reactor Program, ERDA-1535, Volume II, U.S. Energy Research and Development Administration, Washington, DC, 1975.

4.8 Washington State Advance Counts, Table I, Persons by Race and Spanish Origin and Housing Unit Counts, U.S. Bureau of Census, Washington, $D C$, 1981.

4.9 D. J. Sommer, R. G. Rau, and D. C. Robinson, Population Estimates for the Areas Within a 50-Mile Radius for Four Reference Points on the Hanford Site, PNL-4010, Pacific Northwest Laboratory, Richland, WA, 1981.

4.10 J. Piott and D. Shau, Annual Demographic Information, January 1984, Service Delivery Area XI, Benton, Franklin, and Walla Walla Counties, Washington State Emp Toyment Security Department, OTympia, WA, 1984.

4.11 Site Characterization Report for the Basalt Waste Isolation Project, DOE/RL 82-3, U.S. Department of Energy, Washington, DC, 1982.

4.12 Draft Environmental Statement Related to the Construction of Skagit/ Hanford Nuclear Project Units 1 and 2, Dockets STN 50-522 and STN 50-523, Puget Sound Power and Light Company, The Washington Power Company, Portland General Electric; NUREG-08794, U.S. Nuclear Regulatory Commission, Washington, DC; and Washington State Energy Evaluation Council, Olympia, WA,

4.13 Environmental Assessment, Reference Repository Location, Hanford Site, Washington, D0E/RW-0070, U.S. Department of Energy, Washington, DC, 1986 .

4.14 Washington State National Register of Historic Places, Washington State Office of Archeology and Historic Preservation, 01ympia, WA, 1981.

4.15 C. S. Cline et al., Ground-Water Monitoring of the Hanford Site for CY-1984, PNL-5408, Pacific Northwest Laboratory, Richland, WA, 1985.

4.16 E. H. McKee, D. A. Swanson, and T. L. Wright, "Duration and Volume of Columbia River Basalt Volcanism: Washington, Oregon and Idaho." Geological Society of America, Abstracts with Programs 9 (4), pp. 463-464, 1977 .

4.17 T. H. Mitchell and K. A. Bergstrom, "Pre-Columbia River Basalt Group Stratigraphy and Structure in the Central Pasco Basin," Preliminary Interpretation of the Tectonic Stability of the Reference Repository Location, Cold Creek Syncline, Hanford Site, RHO-BWI-ST-19P, Rockwel1 Hanford Operations, Richland, WA, 1983. 
4.18 C. W. Myers et al., Geologic Studies of the Columbia Plateau - A Status Report, RHO-BWI-ST-4, Rockwell Hanford Operations, Richland, WA, 1979.

4.19 C. W. Myers et a1., Subsurface Geology of the Cold Creek Syncline. RHO-BWI-ST-14, Rockwell Hanford Operations, Richland, WA, 1981.

4.20 B. A. Napier, Standardized Input for Hanford Environmental Impact Statements, Part I, PNL-3509, PT 1, Pacific Northwest Laboratory, Richland, WA, T98T.

4.21 K. R. Price, J. M. V. Carlile, R. L. Dirkes, R. E. Jaquish, M. S. Trevathan, and R. K. Woodruff, Environmental Monitoring at Hanford for 1984, PNL-5407, Pacific Northwest Laboratory, Richland, WA, T985.

4.22 L. E. Rogers and W. H. Rickard, Ecology of the 200 Area Plateau Waste Management Environs: A Status Report, PNL-2253, Pacific Northwest Laboratory, Richland, WA, 1977.

4.23 M. J. Sula and P. J. Blumer, Environmental Surveillance of Hanford for CY-1980, PNL-3728, Pacific Northwest Laboratory, Richland, WA, 1981.

4.24 M. J. Sula et al., Environmental Surveillance of Hanford for CY-1981, PNL-4211, Pacific Northwest Laboratory, Richland, WA, 1982.

4.25 Lower Columbia River Standard Project Flood and Probable Maximum Flood, US Army Corps of Engineers, North Pacific Division, Portiand, 0R, 1969.

4.26 N. D. Watkins and A. K. Baksi, "Magnetostratigraphy and Oroclinal Folding of the Columbia River, Steens, and Owyhee Basalts in Oregon, Washington, and Idaho." American Journal of Science 274 (148), 1974.

4.27 D. W. Coats and R. C. Murray, Natural Phenomena Hazards Modeling Project: Seismic Hazard Models for Department of Energy Sites, UCRL-53582, Lawrence Livermore National Laboratory, Livermore, CA, November 1984.

4.28 D. W. Coats, Natural Phenomena Hazards Modeling Project: Extreme Wind/Tornado Hazard Models for Department of Energy Sites, UCRL -53526 , Rev. T, Lawrence Livermore National Laboratory, Livermore, CA, 1985.

5.1 DOE Order RL 5480.10, "Industrial Hygiene Program," US Department of Energy, Richland Operations Office, Richland, WA, August 27, 1986.

5.2 P. R. Prevo and D. 0. Hess, Radiation and Environmental Protection Experience at the Fast Flux Test Facility, HEDL-SA-3241, Hanford Engineering Development Laboratory, Richland, WA, April 18, 1985.

5.3 Code of Federal Regulations, "National Emission Standards for Hazardous Air Pollutants," 40 CFR 61, U.S. Environmental Protection Agency, Washington, DC, 1985. 
5.4 R. E. Hollingsworth, Environmental Statement: Fast Flux Test Facility, WASH-1510, U.S. Atomic Energy Commission, Richland, WA, May 1972.

5.5 Code of Federal Regulations, "National Primary and Secondary Ambient Air Quality Standards," 40 CFR 50, U.S. Environmental Protection Agency, Washington, OC, 1985.

5.6 Code of Federal Regulations, "Hazardous Waste Management System: General," 40 CFR 260, U.S. Environmental Protection Agency, Washington, DC, 1985.

5.7 Code of Federal Regulations, "Identification and Listing of Hazardous Waste," 40 CFR 261, U.S. Environmental Protection Agency, Washington, DC, 1985.

5.8 Code of Federal Regulations, "Standards Applicable to Generators of Hazardous Waste," 40 CFR 262, U.S. Environmental Protection Agency, Washington, DC, 1985.

5.9 Code of Federal Regulations, "Standards Applicable to Transporters of Hazardous Waste," 40 CFR 263, U.S. Environmental Protection Agency, Washington, DC, 1985.

5.10 Code of Federal Regulations, "Standards for Owners and Operators of Hazardous Waste Treatment, Storage, and Disposal Facilities," 40 CFR 264, U.S. Environmental Protection Agency, Washington, DC, 1985.

5.11 Code of Federal Regulations, "Interim Status Standards for Owners and Operators of Hazardous Waste Treatment, Storage, and Disposal Facilities," 40 CFR 265, U.S. Environmental Protection Agency, Washington, DC, 1985.

5.12 Code of Federal Regulations, "Standards for the Management of Specific Hazardous Wastes and Specific Types of Hazardous Waste Management Facilities," 40 CFR 266, U.S. Environmental Protection Agency, Washington, DC, 1985.

5.13 Code of Federal Regulations, "Reactor Site Criteria," 10 CFR 100, U.S. Nuclear Regulatory Commission, Washington, DC, January 1, 1987.

5.14 L. H. Bullis and J. E. Mielki, Strategic and Critical Materials, Westview Press, Inc., Boulder, C0, 1985.

6.1 R. W. Bartram and A. Weityberg, Radiological Risk Analysis of Potential SP-100 Space Mission Scenarios, NUS Corporation, Gaithersburg, MD, August 1988.

6.2 Civil Applications of Nuclear Power - Final Report of the Civil Missions Advisory Group, U.S. National Aeronautics and Space Administration, Washington, DC, September 1984. 
6.3 SP-100 Space Reactor Safety, DOE/NE-0083, U.S. Department of Energy, Washington, DC, May 1987.

6.4 Hazard Analysis of Commercial Space Transportation, Volumes I, II, and II, U.S. Department of Transportation, Washington, DC, May 1988.

6.5 R. Brown, "Supporting Data for Probability Estimate," U.S. National Aeronautics and Space Administration, Presented at the DOE/INSRP Shuttle Data Book Meeting, Gaithersburg, MD, March 29-30, 1988.

6.6 The Effects on Population of Exposures to Low Levels of Ionizing Radiation, National Academy of Sciences - National Research Council, Committee on the Biological Effects of Ionizing Radiation (BEIR III), 1980 .

7.1 Code of Federal Regulations, "National Emission Standards for Hazardous Air Pollutants, "40 CFR 61, U.S. Environmental Protection Agency, Washington, DC, 1985.

7.2 Code of Federal Regulations, "National Primary and Secondary Ambient Air Quality Standards," 40 CFR 50, U.S. Environmental Protection Agency, Washington, DC, 1985.

7.3 Code of Federal Regulations, "National Interim Drinking Water Regulations," 40 CFR 14T, U.S. Environmental Protection Agency, Washington, DC, 1985.

7.4 Code of Federal Regulations, "Hazardous Waste Management System: General," 40 CFR 260, U.S. Environmental Protection Agency, Washington, DC, 1985.

7.5 Code of Federal Regulations, "Identification and Listing of Hazardous Waste," 40 CFR 261, U.S. Environmental Protection Agency, Washington, DC, 1985 .

7.6 Code of Federal Regulations, "Standards Applicable to Generators of Hazardous Waste," 40 CFR 262, U.S. Environmental Protection Agency, Washington, DC, 1985.

7.7 Code of Federal Regulations, "Standards Applicable to Transporters of Hazardous Waste," 40 CFR 263, U.S. Environmental Protection Agency, Washington, DC, 1985.

7.8 Code of Federal Regulations, "Standards for Owners and Operators of Hazardous Waste Treatment, Storage, and Disposal Facilities, " 40 CFR 264, U.S. Environmental Protection Agency, Washington, DC, 1985.

7.9 Code of Federal Regulations, "Interim Status Standards for Owners and Operators of Hazardous Waste Treatment, Storage, and Disposal Facilities," 40 CFR 265, U.S. Environmental Protection Agency, Washington, DC, 1985. 
7.10 Code of Federal Regulations, "Standards for the Management of Specific Hazardous Wastes and Specific Types of Hazardous Waste Management Facilities," 40 CFR 266, U.S. Environmental Protection Agency, Washington, DC, 1985.

7.11 Washington Administrative Code, "Washington State Air Pollution Control Regulations," Tit7e 18, Chapter 173-400, 1980.

7.12 Washington Administrative Code, "Washington State Dangerous Waste Regulations," Title 18, Chapter 173-303, 1984.

7.13 Code of Federal Regulations, "Hazardous Materials Tables \& Hazardous Materials Regulations;" "Shippers - General Requirements for Shipment and Packagings;" "Shipping Container Specifications;" "Specifications for Tank Cars," 49 CFR 172, 173, 178, and 179, U.S. Department of Transportation, Washington, DC, November 1, 1985.

7.14 DOE Order RL 5480.1, "Environmental Protection, Safety, and Health Protection Program for Richland Operations," Chapter III, U.S. Department of Energy, Richland, WA, October 31, 1983.

7.15 Washington Administrative Code, "Washington State Ambient Standards for Emission of Radionuclides," Title 18, Chapter 173-480, "Ambient Air Quality Standards and Emission Limits for Radionuclides, "Olympia, WA, 1986.

7.16 DOE Order 5480.3, "Safety Requirements for the Packaging and Transportation of Hazardous Materials, Hazardous Substances, and Hazardous Wastes, "U.S. Department of Energy, Washington, DC, JuTy 9, 1985.

8.1 DOE Order 5440.1C, "Implementation of the National Environmental Policy Act," U.S. Department of Energy, Washington, DC, April 9, 1985. 
A P P E N D I X A

CALCULATION OF RADIATION DOSES

AND CONVERSION OF DOSES TO HEALTH EFFECTS

$A-1$ 
Blank Page 


\section{CALCULATION OF RADIATION DOSES}

AND CONVERSION OF DOSES TO HEALTH EFFECTS

The potential impacts of constructing and operating the GES Test are presented in Section 5.0. Impacts are evaluated by the resultant public doses. The doses are based on the radionuclide releases summarized in Section 5.0. This appendix lists the computer codes used to calculate the resultant doses and discusses the bases for converting them to health effects.

\section{A.1 STANDARD CALCULATION MODELS AND CODES USED AT HANFORD}

A set of computer programs to calculate radiation doses from all significant exposure pathways has been developed at Hanford. Each program accesses a common set of libraries that, as much as possible, contain Hanford-specific data. The programs and libraries are maintained by the Hanford Dose Overview Program (Reference A.1); and a quality assurance plan for the programs is also in place.

The computer programs are documented separately. A brief description of the programs used for this document and their applications is given in Table A.1.

TABLE A. 1

COMPUTER PROGRAMS FOR CALCULATING RADIATION DOSES

\begin{tabular}{|c|c|c|}
\hline $\begin{array}{l}\text { Release } \\
\text { Type }\end{array}$ & Dose Type & Program \\
\hline Acute & $\begin{array}{l}\text { Inhalation } \\
\text { Submersion }\end{array}$ & $\begin{array}{l}\text { DACR IN }(A .2) \\
\operatorname{SUBDOSA}(A .3)\end{array}$ \\
\hline Chronic & $\begin{array}{l}\text { Inhalation } \\
\text { Submersion } \\
\text { Ingestion } \\
\text { Exposure from } \\
\quad \text { Ground Contamination }\end{array}$ & $\begin{array}{l}\text { DACRIN }(A .2) \\
\text { KRONIC }(A .4) \\
\operatorname{PABLM}(A .5) \\
\operatorname{PABLM}(A .5)\end{array}$ \\
\hline
\end{tabular}




\section{A.2 RADIOLOGICALLY RELATED HEALTH EFFECTS}

The potential radiological impact of the GES Test on people living close to the Hanford Site was evaluated in terms of doses. These were used to estimate health effects. This section contains supplemental information for estimating such health effects. Most of the information is documented in Appendix C of Reference A.6.

Radiation doses to people from ingestion, inhalation, or external exposure to specified amounts of radionuclides can be calculated with reasonable confidence. However, estimates of the amounts of radioactive materials that may be released during GES Test operations and fractions that could reach people by different pathways are not well defined. Since conservative assumptions were made in this assessment, errors from lack of sufficient knowledge will result in overestimating (rather than underestimating) doses. Subsequent design and use of radiation protection measures (based on these estimated doses) will provide more than adequate protection.

Only minimal releases of radioactive materials were predicted. Thus, acute health effects that show up anywhere from immediately to a few weeks after exposure (depending on the dose) are not considered. Generally, acute effects, such as suppressed blood cell counts, nausea, hair loss, fatigue, and diarrhea, do not occur from doses less than 100 rems. The effects manifested and their severity depend on the dose. From an exposure of 100 rems $(100,000$ mrems $)$, only slight decreases in blood cell counts and possibly nausea would occur.

Long-delayed somatic and genetic effects in the population from operation of the GES Test were considered. These effects, including cancer, would only occur, if at all, in a very small fraction of the people exposed.

The relationship between health effects and low-level radiation doses can only be estimated by observing effects from much higher radiation doses. High-level dose effects have been extensively studied and documented. The number of health effects caused by exposure to low levels of radiation is, thus, determined by extrapolation. That is, a linear dose-effect curve (on 
a plot of dose versus health effects) is extended below the point (dose) of observable effects (although this linear relationship has not been proven). These values then become standards in estimating health effects from normal operations. This linear dose-effect assumption results in conservative estimates of health effects from low doses. In this context, the National Council on Radiation Protection and Measurements (NCRP) has said: "The NCRP wishes to caution governmental policy-making agencies of the unreasonableness of interpreting or assuming 'upper limit' estimates of carcinogenic risks at low radiation levels derived by linear extrapolation from data obtained at high doses and dose rates, as actual risks, and of basing unduly restrictive policies on such interpretation or assumption. "(A.7)

This Environmental Assessment employed a range of 50 to 500 cancer deaths per million person-rems. As indicated in Table A.2, this is the range for cancer risk discussed in the BEIR III report $(A .8)$ and the Health Effects Model of the NRC. (A.10) Current data indicate that the possibility of zero risk from very low dose cannot be assured. All estimates of health effects in this Environmental Assessment are based on the risk factors in Table A.2.

TABLE $A .2$

RISK FACTORS FOR HEALTH EFFECTS

USED IN THIS ENVIRONMENTAL ASSESSMENT

Type of Risk

Fatal Cancers

from Whole-Body Exposure

Specific Genetic Effects

to All Generations

from Whole-Body Exposure

Total Risk
Predicted Incidence (per million person-rem)

50 to 500

100 to 1000

A range of 50 to 500 specific genetic effects to all generations per million person-rems of exposure was employed in this Environmental Assessment. This is the range for genetic risk discussed in the BEIR III report, $(A .8)$ the 1982 UNSCEAR report, $(A .9)$ and NRC's radiological Health Effects Model. (A.10) 
A. $3 \quad$ REFERENCES

A.1 W. D. McCormack, J. V. Ramsdell, and B. A. Napier, Hanford Dose Overview Program: Standardized Methods and Data for Hanford Environmental Dose Calculations, PNL-3777, Rev. 1, Pacific Northwest Laboratory, Richland, WA, May 1984.

A.2 J. R. Houston, D. L. Strenge, and E. C. Watson, DACRIN - A Computer Program for Calculating Organ Dose from Acute or Chronic Radionuclide Inhalation, BNWL-B-389, Pacific Northwest Laboratory, Richland, WA, August 1975.

A.3 D. L. Strenge, E. C. Watson, and J. R. Houston, SUBDOSA - A Computer Program for Calculating External Doses from Accidental Atmospheric Releases of Radionuclides, BNWL-B-351, Pacific Northwest Laboratory, Richland, WA, June 1975.

A.4 D. L. Strenge and E. C. Watson, KRONIC - A Computer Program for Calculating Annual Average External Doses from Chronic Atmospheric Releases of Radionuclides, BNWL-B-264, Pacific Northwest Laboratory, Richland, WA, June 1973.

A.5 B. A. Napier, W. E. Kennedy, Jr., and J. K. Soldat, PABLM - A Computer Program to Calculate Accumulated Radiation Dose from Radionuclides in the Environment, PNL-3209, Pacific Northwest Laboratory, Richland, WA, March 1980.

A.6 Draft Environmental Impact Statement, Process Facility Modifications Project, D0E/EIS-0115D, U.S. Department of Energy, Washington, DC, 1986.

A.7 Natural Background Radiation in the United States, Report No. 45, National Council on Radiation Protection and Measurements (NCRP), Bethesda, MD, 1975.

A.8 The Effects on Populations of Exposure to Low Levels of Ionizing Radiation, BEIR III Report, National Academy of Sciences, Committee on the Biological Effects of Ionizing Radiation, Washington, DC, 1980.

A.9 Ionizing Radiation: Sources and Biological Effects, United Nations Scientific Committee on Atomic Radiation (UNSCEAR), United Nations, New York, NY, 1982.

A. 10 Health Effects Model for Nuclear Power Plant Accident Consequence Analysis, NUREG/CR-4214, Vol. 2, Nuclear Regulatory Commission, Washington, DC, 1985. 
A P P E D I X B

HAZARDS IDENTIFICATION ANALYSIS

B-1 
Blank Page 


\section{HAZARDS IDENTIFICATION ANALYSIS}

\section{B.1 SUMMARY}

Systematic identification of all hazards or potential hazards associated with the SP-100 GES test activity has been performed. Emphasis, at the preconceptual stage in design, has been on identification of those hazards that will drive design. The major hazards that will have to be accommodated by design are radioactive materials, liquid metals, inert gas, fires, toxic materials, and hazardous materials such as beryllium.

\section{B.2 PRELIMINARY HAZARD ANALYSIS}

\section{B.2.1 Hazard Identification}

Systematic identification of all hazards or potential hazards associated with the SP-100 GES test activity has been performed with the results summarized below. The systematic identification program used standard tables of hazards for DOE facilities, (B. I) a review of hazards associated with comparable operations (including liquid metal reactor facilities), $(B .2, B .3$ ) and a survey of preconceptual design plans.

\section{B.2.2 Survey Methodology}

The survey was performed following the general procedural steps:

1) Identify all hazards associated with each system.

2) Quantify the hazardous material.

3) Identify probable and possible effects.

4) Identify potential targets in terms of equipment, personnel, the general public, and the environment.

5) Describe probable mitigation, control, and protection features planned. 
6) Identify how off-normal conditions will be detected.

7) Identify the maximum credible chronic release. Reasonable assumptions on state-of-the-art technology are incorporated.

8). Identify the maximum acute (short-term accident caused) release and the probable release mechanism.

\section{B.2.3 Scope of Analyses}

Identification and analys is of maximum acute (accident) release is to be based on a level of analysis reasonable for an Environmental Analysis. In preparing this Environmental Assessment, a reasonable effort is made to obtain missing information that is important in evaluating significant adverse impacts on the human environment. Such information is consistent with the state of the art and factors in the overall costs. If missing information cannot be obtained for the Environmental Assessment, a summary of existing credible relevant scientific and technical evidence is provided. All reasonably foreseeable impacts are identified, even though their probability of occurrence is low, provided that they have credible scientific support and are not based on pure conjecture.

\section{B.3 PRELIMINARY HAZARD SURVEY}

\section{B.3.1 Radioactive Sources}

\section{B.3.1.1 Hazard: Nuclear Fuel Materials}

- Possible causes: Fuel (Uranium Nitride - highly enriched)

- Quantity: Variable (depending on reactor design) but $\sim 360 \mathrm{~kg} 235 \mathrm{U}$

- Possible effects:

-- Unplanned criticality potentially exists with accompanying high exposures.

-- Release of uranium may result from a handling accident.

- Potential targets: Operating personnel and the general public during reactor assembly and handling 
- Planned mitigation, control, and protection features: Proper reactor assembly/transport/installation/disassembly procedures

- Means and features of condition detection:

-- Radiation monitoring

-- Criticality alarms

- Maximum acute release: All handling of fuel material outside approved shipping containers will be within the 309 Building containment. Gross failure of the fuel with substantial release within the containment would require a mechanical (crane) failure with physical damage to the fuel. Assumed fractured fuel release into the containment is $10 \%$ or $36 \mathrm{~kg}$. Release to the environment would be limited by particle size distribution and by exhaust HEPA filtration. Offsite criticality dose commitments due to fission product release would be bounded by the fission product hazards discussed in Section B.3.1.2.

\section{B.3.1.2 Hazard: Fission Products}

- Possible causes: Irradiation of fissionable nuclear fuels will result in accumulation of radioactive fission products. Multiple boundary failures would be required for release.

- Quantity: Depends primarily on total irradiation time and upon power-history during operation. Assessments were performed as part of the bounding fission product inventory analyses (see Appendix C).

- Possible effects:

-- In the event of cladding failure, contamination of primary piping/pumps/IHX will make maintenance difficult.

-- In the event of cladding, primary boundary, and vacuum vessel failure, fission products will be released into the facility containment building, with high dose rates observed in areas requiring operator access.

-- In the event of cladding, primary boundary, vacuum vessel, and containment failure, a release will result in exposure to personnel on- and offsite.

- Potential targets:

-- Primary piping/pumps/IHX, reactor, and coolant

-- Operating personnel, if primary system breaches during reactor maintenance/removal/disassembly 
-- Offsite personnel

- Planned mitigation, control, and protection features:

-- Adequate fuel pin design

- Adequate safety system design to ensure protection of the primary, secondary, and containment boundaries, including design features to protect against all credible accidents

-- Vacuum vessel boundary will provide mitigation

-- Proper equipment and maintenance handling procedures

- Means and features of condition detection: Various fission product detection systems

- Maximum acute release: The maximum fission product inventory is based on two years of full-power continuous operation (the maximum operation duration considered). The scenarios considered are:

-- A reactor handling accident following shutdown of 180 days during which all noble gas and appropriate volatile fission products are postulated to be released into containment. HEPA filtration is applied to the containment exhaust. Irradiated reactor handling will not be initiated until the core has cooled. After the core has cooled sufficiently, it will be cleaned by flushing with anhydrous ammonia; and handling will begin. The fission product inventory and the delay period will increase with increasing operation at power. A nominal delay of 180 days was selected for the maximum full-power fission product inventory planned.

-- A power accident resulting in fuel failure, primary boundary failure, and release of all noble gas and appropriate volatile fission products into containment.

- Maximum credible chronic release: Fuel pins and the primary boundary will be designed to provide adequate boundary to preclude chronic releases.

\section{B.3.1.3 Hazard: Tritium}

- Possible causes:

- Activation of lithium coolant in core

-- Activation of lithium hydride shield (if used)

-- Reaction of neutrons with boron-10 in control rods 
- Quantity: Tritium accumulation will depend on irradiation history. Scoping analyses were performed to determine bounding production rates of $5 \mathrm{Ci} /$ day in coolant, up to $5 \mathrm{Ci} /$ day in shield, and $1 \mathrm{Ci} /$ day from control rods.

- Possible effects:

-- Tritium in primary 1 ithium will diffuse through primary boundary into vacuum vessel and may diffuse into secondary sodium, with potential release to environment.

-- Tritium in shield may be released to the vacuum vessel in high-temperature transient or as a result of shield canning failure, with potential release to environment..

- Potential targets:

-- Operations personnel

-- Possible offsite release during off-normal events

- Planned mitigation, control, and protection features:

- Cold traps will control tritium in secondary system by precipitation of $\mathrm{NaH}$.

-- Tritium getters will control tritium in the vacuum system.

-- The maximum tritium inventory will be limited to $1800 \mathrm{Ci}$ in the holding system (getters).

-- Tritium will be contained in shielding by design.

- Means and features of condition detection:

-- Tritium releases will be monitored by on-line monitoring in Tritium Removal System.

-- Release will also be monitored by periodic environmental sampling.

- Maximum acute release: Multiple barriers to tritium release exist. The maximum mechanistically credible release is $1800 \mathrm{Ci}$, which would result from an operational failure of the vacuum pumping system plus gross failure of the Tritium Removal System.

- Maximum credible chronic release: Tritium Removal System can be obtained with tritium transmission efficiencies of $1 \times 10^{-9}$ or better. Chronic releases of $1 \times 10^{-4} \mathrm{Ci}$ per day are projected, based upon continuous release of tritium to the vacuum system from the core ( $5 \mathrm{Ci} /$ day) and upon Tritium Removal System capability. 


\section{B.3.1.4 Hazard: Activated Corrosion Products and Activated Coolant}

- Possible causes: Activation of materials in the primary or secondary system.

- Quantity: Assessments were performed to bound the maximum secondary system activation at less than $86 \mathrm{Ci}$ of $54 \mathrm{Mn}, 1.2 \mathrm{Ci}$ of $60 \mathrm{Co}, 1.2 \mathrm{Ci}$ of $22 \mathrm{Na}$, and $170 \mathrm{Ci}$ of $24 \mathrm{Na}$. These isotopes may be present in the secondary coolant. Primary activation products were determined to be less significant than fission products for all accidents analyzed.

- Possible effects:

-- High residual gamma fields of the primary and secondary coolant system components will result from plateout of corrosion products.

-- Releases may result from corrosion products in solution in liquid metals.

- Potential targets:

-- Personnel exposures may result from work adjacent to this system.

-- Exposure to the surrounding population may result if a liquid metal fire occurs.

- Planned mitigation, control, and protection features:

- Cold traps to reduce corrosion

- Shielding of secondary components from neutrons

- Maximum acute release: The postulated release scenario is based on a secondary system leak and fire. The secondary sodium system will consist of two separate and isolatable loops. Approximately half of the volume of each loop is within containment; to enhance natural circulation the portion of the loop outside containment will be at a higher elevation. Leakage will amount to less than one third the coolant (and corrosjon products). However, $43 \mathrm{Ci}$ of $54 \mathrm{Mn}, 0.6 \mathrm{Ci}$ of $60 \mathrm{Co}, 0.6 \mathrm{Ci}$ of $22 \mathrm{Na}$ and $85 \mathrm{Ci}$ of $24 \mathrm{Na}$ are assumed released; that is, a conservative assumption is made that half of the corrosion product inventory is released.

- Maximum credible chronic release: No chronic release mechanism has been identified. 


\section{B.3.1.5 Hazard: Activated Gases}

- Possible causes: Argon-40 (present as a trace element in air or nitrogen) may be in the vicinity of the reactor; activation yields argon-41.

- Quantity: Based on the no reactor shielding, production from argon activation may be as high as $0.1 \mathrm{Ci} /$ day.

- Possible effects: Routine releases of argon-41 provide exposure to general public and operators.

- Potential targets: General public and operators.

- Planned mitigation, control, and protection features:

-- Cavity exhaust will be delayed.

-- Neutron shielding of cavity gas will be provided.

-- Vacuum vessel cell atmosphere will be evaluated and selected to minimize activation.

- Means and features of condition detection: Exhaust monitoring will be provided.

- Maximum acute release: No significant acute release mechanism has been identified. Argon-4l accumulation will be limited.

- Maximum credible chronic release: Because argon-41 has a 1.83-h half-life and because its release will be minimized by providing shielding and adequate delay holdup of vacuum system and cavity gases, chronic releases will be substantially below the production rate of $20.1 \mathrm{Ci} /$ day. The design will ensure a release less than $0.01 \mathrm{Ci} / \mathrm{day}$.

\section{B.3.1.6 Hazard: Radiation Fields}

- Possible causes:

- Neutron and gamma radiation resulting from reactor operation

-- Gamma radiation from decay of fission products

- Activated materials (fuel, cladding, structural materials, shield materials) resulting from neutron irradiation 
- Quantity: Fields in excess of $1000 \mathrm{rem} / \mathrm{h}$ are expected in close proximity to the unshielded reactor.

- Possible effects: Radiation damage to equipment and exposure to personnel.

- Potential targets:

-- Operations personnel may receive doses in excess of WHC administrative limits if not protected.

- Equipment exposed to high neutron or gamma fields may have effective lifetime reduced.

- Planned mitigation, control, and protection features:

-- Shielding of areas requiring routine operator access will be provided.

-- Equipment (including electrical lines) subjected to high fields will be qualified for such service.

- Means and features of condition detection:

-- Fields in various areas will be monitored by local area monitoring systems.

-- Radiation surveys will be performed during initial startup of the facility.

\section{B.3.2 Liquid Metals}

\section{B.3.2.1 Hazard: Lithium}

- Possible causes:

-- Lithium will be used as the primary coolant medium. Lithium handling activities will include purification, filling the reactor, operating at power with lithium coolant, and draining the lithium following operation.

- Quantity: 100 to $200 \mathrm{~kg}$ 
- Possible effects:

-- At elevated temperatures, lithium is pyrophoric.

-- Tritium is produced under neutron bombardment.

- The more probable small leak could cause local equipment damage because of corrosion.

-- For a large leak, a lithium concrete reaction could occur it hot lithium reaches concrete.

- For a large leak, if the lithium contacts free-standing water or other reactive chemicals, there could be a violent reaction.

- Potential targets:

-- Operating personnel and equipment

- Public (If fire reaches outside containment, the combustion products are toxic.)

- Planned mitigation, control, and protection features:

-- Lithium will be maintained in closed systems and under an inert atmosphere.

- $\quad$ Primary piping will normally be maintained in a vessel under vacuum; in the event of a vacuum loss, the vessel will be filled with inert gas.

-- Lithium systems will be in containment.

-- Lithium will be purified to limit corrosion rates.

- Means and features of condition detection:

-- Pressure monitor (inside vacuum chamber)

- Fire detectors

- Maximum acute release: Lithium will normally be handled in containment, but will be shipped in drums. In a non-HEPA protected area, the credible release is limited to one drum (55 gal). As shown in Appendix C, a larger release (up to a factor of 10X) would be of minimal impact.

- Maximum credible chronic release: No release mechanism was identified. 


\section{B.3.2.2 Hazard: Sodium}

- Possible causes: Sodium will be used in the Secondary Heat Transport System. Sodium handling activities will include filling of the secondary system, operation at power, routine on-line purification, and final drain of sodium following operation.

- Quantity: The maximum inventory of the secondary HTS is estimated to be 900 gallons. Based on experience with other sodium loops, a leak before a break is probable. This will allow for early detection and for limited leakage quantities.

- Possible effects:

-- A large leak would result in the production of corrosive sodium oxide/hydroxide fumes.

-- The more probable small leak could cause local equipment damage because of corrosion.

-- Sodium/concrete reaction could occur if hot sodium reaches concrete.

-- If the sodium contacts free-standing water or other reactive chemicals, there could be a violent reaction.

- Potential targets:

-- Operation and site personnel

-- General public

- Planned mitigation, control, and protection features:

-- Sodium-containing equipment will, for the most part, be in enclosures. An exception will be the DHXs, though even these are fitted with dampers and a catch pan to reduce the effect of a sodium spill.

- - The concrete floors will be protected by steel liners; in some cases, an additional perforated cover plate will be provided to more fully contain the sodium and restrict the inflow of air. Walls will be protected as required.

- Means and features of condition detection:

-- Leak detectors in the form of sparkplugs and/or ionizationtype detectors will be placed for local leak detection (e.g., a sodium leak at a valve stem seal) or for space leak detection. 
-- Gross leak detection may be supplemented by monitoring the level in the sodium surge tanks.

- Maximum acute release: The limiting sodium spill external to the containment is 500 gallons (see discussion in Section B.3.1.4 above). The effects of a spill can be reduced, through catch pans and enclosures, by one to two orders of magnitude.

\section{B.3.2.3 Hazard: Water in Cells A or B Reacting with Liquid Metal}

- Possible causes: Chilled water is used for cooling in existing recirculation air handlers. Chilled water may be used for vacuum vessel cooling.

- Quantity: If design allows, several hundred gallons may leak into the vicinity of liquid metal systems. A simultaneous sodium leak into the same area could result in liquid metal/water reactions.

- Possible effects: Sodium and lithium may react with water to form hydrogen. Hydrogen mixed with air may be explosive.

- Potential targets:

- Facility control systems could be adversely impacted by a hydrogen explosion.

- Cell boundaries could be challenged by hydrogen explosions.

- Planned mitigation, control, and protection features: Water will be eliminated or separated from 1 iquid metal systems by adequate barriers. Water will not be allowed in direct proximity with liquid metal systems. Areas into which liquid metal can leak will be provided with liquid metal catch pans to maintain separation, even in the event of a water leak. Inert gas atmospheres will be evaluated as an additional means of prevent rapid combination of air and hydrogen.

- Means and features of condition detection:

-- Liquid metal leak detection systems will be provided.

- Water inventories will be monitored. 


\section{B.3.3 Gas Handling Safety Hazards}

\section{B.3.3.1 Hazard: Helium}

- Possible causes:

- Helium may be used as a cover gas for the primary heat transport system expansion tank and will be used to "let up" the vacuum vessel. It may leak because of the permeability of metals or because of equipment leaks.

- Cylinders of helium may be used to provide cover gas for welding of refractory metals.

- Quantity: Several thousand cubic feet.

- Possible effects: Localized $0_{2}$ deficiency is lethal to individuals because of suffocation.

- Potential targets:

-- Personnel near compressors, lines, and heat exchangers

-- Operating personnel during test article assembly, welding, etc.

-- Operators during operation

-- Experimenter representatives

- Planned mitigation, control, and protection features:

-- All-welded fittings whenever possible on gas systems

- Proper training, procedures, sufficient ventilation and appropriate breathing apparatus

-- $\mathrm{O}_{2}$ deficiency monitors (fixed)

-- $\mathrm{O}_{2}$ deficiency monitors (portable/personal)

- Routine inspection and maintenance

- Means and features of condition detection:

-- Inventory accounting

-- Operator on-shift checking

-- $\mathrm{O}_{2}$ deficiency alarms 
-- $0_{2}$ monitors (portable) and alarms

-- Controlled access to areas with a potential for oxygen deficiency

\section{B.3.3.2 Hazard: Argon}

- Possible causes:

-- Welding and liquid metal cover gas equipment leaks

-- Leaks in lines, valves, and blowers/compressors

-- Cover gas for welding refractory metals

- Quantity: Several thousand cubic feet.

- Possible effects:

-- Localized $0_{2}$ deficiency is lethal to individuals because of suffocation.

-- Argon tends to settle to lower levels of containment cells.

-- Argon will be activated by neutron flux from the reactor and may result in radioactive releases (see discussion in Section B.3.1.5 above).

- Potential targets :

-- Personnel near compressors, lines, and heat exchangers

-- Operating personnel during test article assembly, welding, etc.

-- Operators during operation

-- Experimenter representatives

- Planned mitigation, control, and protection features:

-- All-welded fittings, whenever possible, on gas systems

-- Proper training, procedures, sufficient ventilation, and appropriate breathing apparatus

- $\mathrm{O}_{2}$ deficiency monitors (fixed)

-- $\mathrm{O}_{2}$ deficiency monitors (portable/personal)

-- Routine inspection and maintenance 
- Means and features of condition detection:

-- Inventory accounting

-- Operator on-shift checking

-- $\mathrm{O}_{2}$ deficiency al arms

-- $0_{2}$ monitors (portable) and alarms

-- Controlled access in areas with potential for oxygen deficiency

\section{B.3.3.3 Hazard: Steam}

- Possible causes: Steam will be used for building heating. Corrosion/erosion and maintenance errors could result in a steam release.

- Quantity: Steam and related piping will be provided to take care of routine containment and service building heating needs. No steam will be present in containment.

- Possible effects:

-- Missiles may be generated from overpressure of steam systems

- Potential targets:

-- Operators

-- Instruments and controls

- Planned mitigation, control, and protection features:

-- Operate within design limits

-- Routine maintenance and inspection

-- Routing of critical instrumentation and controls to protect from steam system failures

- Means and features of condition detection:

-- Qualified maintenance personnel

-- Steam not used in a continuously occupied area

-- Operate within design limits

-. Investigate all leaks 


\section{B.3.3.4 Hazard: Air Receiver Rupture}

- Possible causes: Air receivers may be used for compressed air systems for pneumatic valve and other plant operations. The most likely failure mechanism is corrosion.

- Quantity: Two receivers of $30-\mathrm{ft}^{3}$ volume each presently exist in the facility.

- Possible effects: Missiles may be generated.

- Potential targets:

-. Operators

-- Critical components located in the vicinity

- Planned mitigation, control, and protection features:

-- Inspections and provisions for automatic water drain

-- Relief valves to protect against overpressurization

-- ASME Code (Section XIII) design and periodic inspection

-- Keep critical I\&C away

- Means and features of condition detection: Maintain annual receiver internal inspection and test of relief valves.

\section{B.3.3.5 Hazard: Helium Storage Rupture}

- Possible causes:

-- Material defects

-- Overpressure

- Quantity: 50,000 $\mathrm{ft}^{3}$ in high-pressure tube storage

- Possible effects: Missiles may be generated.

- Potential targets:

-- Operators (see also helium discussion above)

-- Nearby employees

-- Critical instrumentation 
- Planned mitigation, control, and protection features:

-- Isolation wall at tube bank

-- Overpressure protection devices

-- Separation of critical instrumentation

- Means and features of condition detection:

-- Programmed inspection and repair

-- Operator monitoring during shift

B.3.4 Fires (Other Than Liquid Metal)

\section{B.3.4.1 Hazard: Niobium}

- Possible causes: Niobium will be used as the primary boundary. Ignition and minor fire are credible during cutting and welding operations.

- Quantity: $500 \mathrm{~kg}$

- Possible effects: Toxic niobium fumes

- Potential targets: Personnel

- Planned mitigation, control, and protection features:

-- Niobium surfaces will normally be maintained under vacuum or in an inert atmosphere.

-- Niobium handling will be in a HEPA-filtered area.

-- Cutting and welding practices will be controlled by procedure.

- Means and features of condition detection:

-- Smoke detectors

-- Visual inspection

- Maximum acute release: Experience with metal burns indicates that it is difficult to obtain ignition, that a surface layer of oxide will result in a low rate of combustion after an initial period, and that fires in areas with limited air supplies will result in rapid extinguishment. Burns would be limited to cutting chips. 
- Maximum credible chronic release: No release mechanism was identified.

\section{B.3.4.2 Hazard: Bulk (Petroleum) Gas Storage}

- Possible causes: Fuel storage may be required for emergency generators. Overpressure can cause bursting, leakage, and ignition.

- Quantity: $200 \mathrm{ft}^{3}$ pressurized

- Possible effects:

-- Fire may develop.

-- Missiles may be generated.

-- Concussion/overpressure effects

- Potential targets:

$--\quad D H X S$

- Personnel

-- Secondary coolant piping

- Planned mitigation, control, and protection features:

-- Fire suppression equipment

- Separation/shielding

-- Overpressure protection devices

- Means and features of condition detection:

-- Combustion product detection systems as required by safety codes

- Smell/auditory (on operator rounds)

-- Pressure indication 


\section{B.3.4.3 Hazard: Freon}

- Possible causes: Freon will be used in chillers. Freon leakage sources include joint leakage, rupture, and maintenance spills.

- Quantity:

-- 50 gallons active

-- 50 gallons storage

- Possible effects:

-- Minor potential for suffocation.

-- Freon not flammable but, when exposed to flames, it forms phosgene gas, which is toxic.

- Potential targets:

-- Operators

-- Fire fighting personne 1

- Planned mitigation, control, and protection features:

- Evacuation

- Scott airpacs (self-contained breathing apparatus) for entry

- Means and features of condition detection:

- Roving inspection

-- Process instrumentation

B.3.5 Hazardous and Toxic Materials

\section{B.3.5.1 Hazard: Beryllium}

- Possible causes: Control drums/rods as neutron reflector

- Freon is a registered trademark of E.I. duPont de Nemours \& Co., Wilmington, DE. 
- Quantity: Less than $100 \mathrm{~kg}$

- Possible effects: Airborne beryllium is toxic if inhaled.

(However, upon receipt at HEDL, material will be in solid beryllium oxide form and will not pose an inhalation threat.)

- Potential targets:

-- Operating personnel during reactor assembly/disassembly

-- General public only if beryllium oxide should be disintegrated to respirable particles and become airborne as a result of a major accident

- Planned mitigation, control, and protection features:

-- BeO will be canned in all HEDL handling operations.

-- Proper handling procedures/equipment

-- Proper disposal procedures/techniques

- Maximum acute release: If a fire involved the total test article, the niobium structural materials might burn. The BeO is stable and would remain uninvolved. No release is postulated.

- Maximum credible chronic release: No release mechanism was identified.

\section{B.3.5.2 Hazard: Acids and Caustics}

- Possible causes:

-- If a demineralized water system is required, the storage and piping of acid and caustic material may be required. Spills may occur.

- Battery acid will be present in emergency storage batteries. Spills or battery explosions may occur.

-- Caustic from ammonia reaction in HVAC treatment system.

- Quantity: Several gallons to tens of gallons

- Possible effects:

- Chemical burns

-- Hydrogen generation with subsequent explosion 
- Potential targets:

-- Personnel may be injured by acid or caustic burns.

-- Critical equipment may be damaged by hydrogen explosion.

- Planned mitigation control and protection features:

-- Batteries will be provided with "hydrocaps" to minimize hydrogen release.

-- Battery rooms will be ventilated to prevent the buildup of explosive hydrogen levels.

-- Safety showers will be located in acid and caustic handling areas.

\section{B.3.5.3 Hazard: Ammonia}

- Possible causes: Ammonia will be used for post-irradiation liquid metal system cleaning.

- Quantity: Up to 1000 gallons.

- Possible effects: Inhalation of concentrated fumes may be fatal. Ammonia fumes are toxic and irritant by inhalation. Human tolerance is $25 \mathrm{ppm}$ in air.

- Potential targets: Personnel (onsite)

- Planned mitigation, control, and protection features:

-- Standard industrial safety practices

-- Ammonia will be contained in vessels in closed spaces.

-- Vent paths will be designed to react ammonia in an acid solution to ensure that releases are below the human tolerance level.

-- Exhaust via a stack will provide for atmospheric dilution.

- Maximum acute release: No credible path for acute release was identified because of the high precautions taken to contain fission product and activation products that would be dissolved in the ammonia cleaning process. Fission product releases are addressed above. 


\section{B.3.6 Mechanical Hazards}

\section{B.3.6.1 Hazard: Missiles (Kinetic Energy)}

- Possible causes:

-- Flywheel failure on motor generator

-- Pressure vessel failure (see above)

-- Explosions (see above)

- Quantity: A number of pressure vessels and several flywheels may be required for facility operation.

- Possible effects:

-- Injury to operations personne 1

-. Damage to safety-grade equipment

- Potential targets:

-- Operations personnel

-- Safety-grade equipment

- Planned mitigation, control, and protection features:

-- Safety-grade equipment will be shielded and otherwise protected from failures of this nature.

-- Personnel protection will be provided by compliance with accepted codes and standards for such equipment.

- Means and features of condition detection: Periodic inspections will be performed.

\section{B.3.6.2 Hazard: Mechanical (Potential Energy)}

- Possible causes: Crane failure

- Quantity: The facility 30-ton crane and other facility cranes and hoists.

- Possible effects: Extensive mechanical damage can result from the stored energy in a large elevated mass. 
- Potential targets:

-- Personnel

-- Safety-grade equipment

- Planned mitigation, control, and protection features:

-- Cranes will be inspected and load-tested periodically.

-- Operating 1 imitations will be imposed on lifts near critical safety-grade equipment.

\section{B.4 REFERENCES}

B.1 R. J. Nertray et a 1., Occupancy-Use Readiness Manual, ERDA-76-45-1, SSDC-1, Aerojet Nuclear Company, September 1975.

B.2 J. C. Elder et al., A Guide to Radiological Accident Considerations for Siting and Design of DOE Nonreactor Nuclear Facilities, LA-10294-MS, Los Alamos National Laboratory, Los Alamos, NM, January 1986.

B.3 J. E. Hanson, Comparison of Clinch River Breeder Reactor Design Bases Accidents with Those for Light Water Reactors and Liquid-Metal-Cooled Fast Reactors, EGG-NTAP-6152, Idaho National Engineering Laboratory, Idaho Falls, ID, January 1983. 


$$
\text { A P P E N D I X C }
$$

SP-100 ACUTE RELEASE DOSE ANALYSIS DOCUMENTATION

C-1 
Blank Page 


\section{SP-100 ACUTE RELEASE DOSE ANALYSIS DOCUMENTATION}

The following calculations were performed for the originally planned reactor thermal power of $8.0 \mathrm{MW}$. Subsequently the planned power was reduced to 2.5 MW. Because of fission product production, transuranic production, and radiological consequences scale with power level, the analyses of the 2.5-MW case documented in the main text was attained by multiplying the consequences documented here by a factor of 2.5/8.0 or 0.31 .

An overview of the methodology used for acute dose calculation can be found in Appendix A. Further information on the techniques can also be found in NRC Regulatory Guides 1.3 and 1.4. ${ }^{(C .1, C .2)}$

C.1 UNIRRADIATED FUEL HANDLING ACCIDENT

The formula used for calculating concentrations of uranium nitride is:

$$
\text { (M) }\left(F_{1}\right)\left(F_{2}\right)\left(F_{3}\right)(1 / t)(T)(x / Q)(C)=U
$$

where:

$$
\begin{aligned}
M & =\text { Mass of uranium nitride present }(\mathrm{kg}) \\
F_{1} & =\text { Fraction of fuel fractured } \\
F_{2} & =\text { Fraction of fractured fuel of respirable size } \\
F_{3} & =\text { Fraction of respirable particles released } \\
t & =\text { Release time }(\mathrm{s}) \\
T & =\text { Filtration transmission fraction } \\
x / Q & =\text { Atmospheric dispersion factor }\left(\mathrm{s} / \mathrm{m}^{3}\right) \\
C & =\text { Mass conversion factor }(\mathrm{mg} / \mathrm{kg}) \\
U & =\text { Uranium nitride concentration }\left(\mathrm{mg} / \mathrm{m}^{3}\right)
\end{aligned}
$$


The values used for these variables are:

$$
\begin{aligned}
& M=360 \mathrm{~kg} \text { of uranium nitride } \\
& \mathrm{F}_{1}=0.10^{\star} \\
& F_{2}=0.10^{\star} \\
& F_{3}=1.00 * \\
& \mathrm{t}=600 \mathrm{~s} * * \\
& T=5 E-4 \star \star \star \text { for one High Efficiency Particulate Air (HEPA) filter } \\
& \text { stage (C.14) } \\
& T=2.5 E-6 \text { for two HEPA filter stages (C.14) } \\
& x / Q=4.3 E-2 \mathrm{~s} / \mathrm{m}^{3} \text { for onsite individual at } 100 \mathrm{~m} \text { (Reference C.3) } \\
& 4.7 \mathrm{E}-3 \mathrm{~s} / \mathrm{m}^{3} \text { for maximum individual at site boundary }(490 \mathrm{~m}) \\
& \text { (Reference C.3) } \\
& C=1 E+6 \mathrm{mg} / \mathrm{kg}
\end{aligned}
$$

The resulting concentrations are:

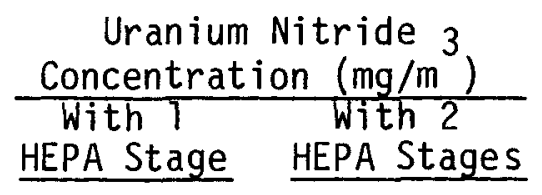

$\begin{array}{lll}\text { Onsite }(100 \mathrm{~m}) & 1.3 \mathrm{E}-1 & 6.5 \mathrm{E}-4 \\ \text { Site Boundary }(490 \mathrm{~m}) & 1.4 \mathrm{E}-2 & 7.1 \mathrm{E}-5\end{array}$

No industry standards exist for airborne concentrations of uranium as a result of an accident. For risk assessment purposes, a criterion of concentrations at or below the accepted occupational levels $\left(0.2 \mathrm{mg} / \mathrm{m}^{3}\right.$ for a 40-h week or $0.6 \mathrm{mg} / \mathrm{m}^{3}$ for occasional short-term exposures (Reference C.4) was chosen for this case. Meeting this criterion requires only one stage of HEPA filtration. Two stages may be provided, making the consequences several orders of magnitude lower than the criterion.

\footnotetext{
*It is assumed as a worst-case assumption that $10 \%$ of the fuel is fractured, that $10 \%$ of the fractured fuel is of respirable size $(<10 \mu \mathrm{m})$, and that $100 \%$ of the respirable particles are released.

**It is conservatively assumed that all of the released material is released in 10 minutes.

$\star \star \star$ The notation $5 E-4$ means $5.0 \times 10^{-4}$.
} 
C.2 IRRADIATED FUEL HANDLING ACCIDENT FOLLOWING COOLDOWN (AFTER 180-DAY SHUTDOWN)

Code Documentation

Computer Codes:

DACRIN (Rev. 1.2, 1980) for inhalation doses

SUBDOSA (10/86) for submersion doses

Calculated Doses: Acute inhalation and submersion, individual receptors at 100 and 490 meters (site boundary) population dose calculated for population within $80 \mathrm{~km}, 50$-year dose commitment for inhalation doses

Files Addressed: $\quad$ Radionuclide Library (RMDLIB) $(1 / 15 / 81)$

Organ Data Library (2/5/81)

Energy Probability Library (10/86)

Submersion Dose

Model:

Finite cloud for individual doses

Semi-infinite cloud for population doses

Assumptions

Release Height: Ground level

Meteorology:

Individual Doses: Worst-case $95 \%$ centerline dispersion factors $(x / Q)$ for all transport directions and ground level release at a wind speed of $0.78 \mathrm{~m} / \mathrm{s}:(C .3)$

$$
\begin{aligned}
& 4.3 E-2 \mathrm{~s} / \mathrm{m}^{3} \text { at } 100 \mathrm{~m} \\
& 4.7 E-3 \mathrm{~s} / \mathrm{m}^{3} \text { at } 490 \mathrm{~m}
\end{aligned}
$$


Population Doses: Worst-case population-weighted $95 \%$ sector-averaged dispersion factor for all transport directions and ground level release at a wind speed of $0.78 \mathrm{~m} / \mathrm{s}$ (dispersion factor data from Reference C.5 and 1990 population data from Reference C.6):

$$
1.17 E-1 \text { person-s/m }{ }^{3}
$$

Removal Mechanisms:

$\frac{\text { Scenario }}{95 \% \text { halogen filtration }}$
1 stage of HEPA filters
2 stages of HEPA filters

Assumed Transmission Factor (C-14)

$$
\begin{aligned}
& 0.05 \\
& 5 \times 10^{-4} \\
& 2.5 \times 10^{-6}
\end{aligned}
$$

Release Time:

One hour (Consequences will not be worse for release duration of less than one hour.)

Source Terms:

Fission product inventories (see Table C.1) were taken from the RIBD output in Reference C.7 and heavy metal inventories from Reference C.8. The RIBD data correspond to the inventories present after 2 years of operation at $8 \mathrm{MW}$ and 180 days after shutdown.

As a conservative assumption, half of the fue 1 elements are assumed to be breached in this event. Release fractions from breached pins (given in the table below) are based on recommendations for nonreactive (oxide) fuel. Since uranium nitride is considered to be a reactive fuel type, the release fractions were assumed to be the more conservative of those for molten fuel and a fire. 
TABLE C.1

\section{SP-100 INVENTORIES (Ci) AFTER 2 YEARS \\ AT 8 MW AND 180 DAYS OF DECAY (Radionuclides Common to RMDLIB and RIBD)}

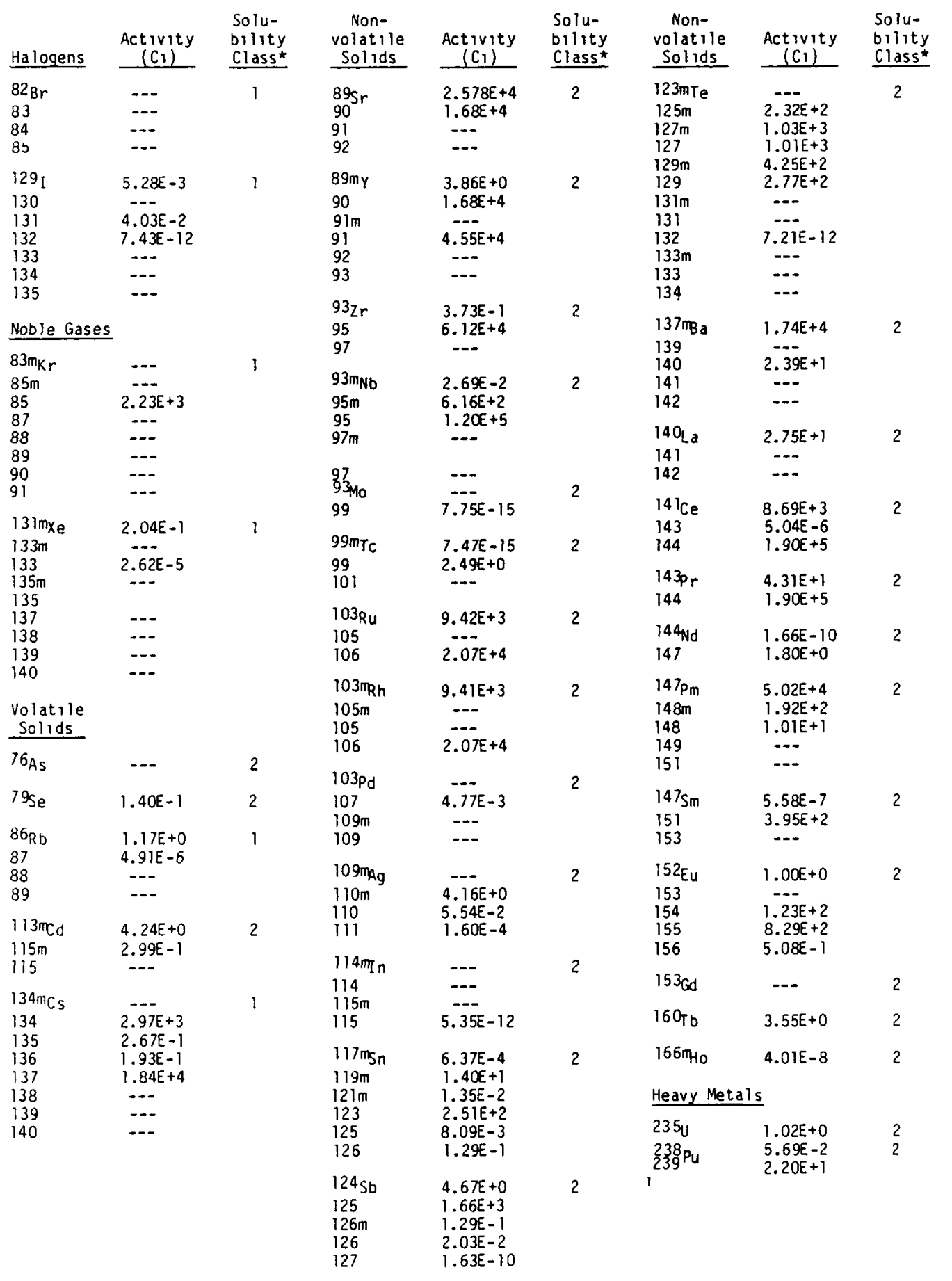

* Solubility class (lung clearance classification) assuming nitrate form: 1 = cleared from lungs in days, 2 = cleared from lungs in weeks, 3 = cleared from lungs in years (Reference C.9). 


\begin{tabular}{|c|c|c|}
\hline Classification & $\begin{array}{l}\text { Release } \\
\text { Fraction }\end{array}$ & $\begin{array}{l}\text { Release } \\
\text { Fraction }\end{array}$ \\
\hline $\begin{array}{l}\text { Halogens } \\
\text { ( including } 50 \% \text { plateout) } \\
\text { Noble Gases } \\
\text { Volatile Solids } \\
\text { Nonvolatile Solids } \\
\text { Heavy Metals (U \& Pu) }\end{array}$ & $\begin{array}{l}0.50 \\
1.00 \\
0.50 \\
0.01 \\
0.01\end{array}$ & $\begin{array}{l}0.25 \\
0.50 \\
0.25 \\
0.005 \\
0.005\end{array}$ \\
\hline
\end{tabular}

The RIBD inventories were entered into the DACRIN and SUBDOSA runstreams. Multiplication factors accounting for release and transmission factors were also used in the runstreams. For SUBDOSA, an additional factor for simulating 95\% centerline stabilities was used. Derivation of these SUBDOSA factors are described in the following section.

Method for Simulating 95\% Centerline Dispersion Characteristics When Using a Finite Cloud Model in SUBDOSA

Use of SUBDOSA with a finite cloud model requires dose rate factor sets that are available for Pasquill $F$ and $G$ stabilities, but not available for the site-specific 95\% centerline stabilities. However, since the $95 \%$ centerline stabilities lie between the Pasquill $F$ and $G$ stabilities, doses corresponding to the $95 \%$ centerline stabilities can be computed as the sum of specific fractions of the doses corresponding to the Pasquill F and $G$ stabilities.

The fractions were computed using the following equations:

$$
\begin{aligned}
(x / Q)_{95} & =a(x / Q)_{F}+b(x / Q)_{G} \\
a+b & =1
\end{aligned}
$$


where:

$$
\begin{aligned}
(x / Q)_{95}= & \begin{array}{r}
95 \% \text { centerline dispersion factor at the given } \\
\text { distance }
\end{array} \\
(x / Q)_{F} \text { and }(x / Q)_{G}= & \begin{array}{l}
\text { Pasquill } F \text { and } G \text { dispersion factors, } \\
\text { respectively, at the given distance }
\end{array} \\
\text { a and } b= & \begin{array}{l}
\text { Weight fractions associated with }(x / Q)_{F} \text { and } \\
(x / Q)_{G} \text {, respectively. }
\end{array}
\end{aligned}
$$

Equations (1) and (2) can be combined into one equation with one variable:

$$
b=\frac{(x / Q)_{95}-(x / Q)_{F}}{(x / Q)_{G}-(x / Q)_{F}}
$$

The $x / Q$ values used in Equation (3) were taken from Reference C.3 using a log-log interpolation to obtain values for 490 meters and are as follows:

$$
\begin{aligned}
& x / 0 \text { Values, all at } 0.78 \mathrm{~m} / \mathrm{s} \text { windspeed }\left(\mathrm{s} / \mathrm{m}^{3}\right)
\end{aligned}
$$

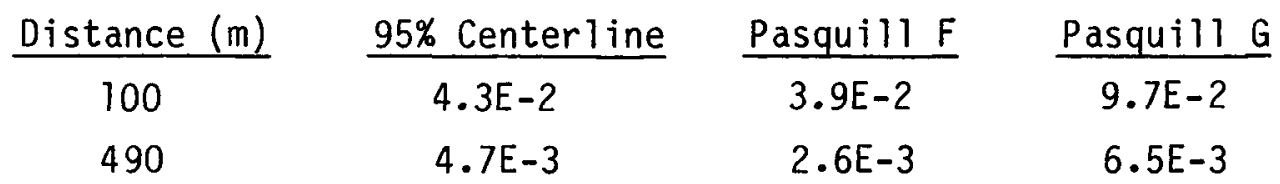

Using these $x / Q$ values and Equations (2) and (3), values were obtained for $a$ and $b$. However, since the dose rate factor sets associated with Pasquill $F$ and $G$ are based on $1 \mathrm{~m} / \mathrm{s}$ windspeed, a correction for the $95 \%$ centerline windspeed of $0.78 \mathrm{~m} / \mathrm{s}$ is required. The values for $a$ and $b$ and the corrected values $a^{\prime}$ and $b^{\prime}$ are as follows:

$\begin{array}{ccccccc}\text { Distance }(m) & \frac{a}{100} & \frac{a^{\prime}}{(a / 0.78)} & \frac{b}{1.194} & & \frac{b}{b^{\prime}} \\ 490 & 0.931 & & \frac{(b / 78)}{0.069} & 0.088 \\ 0.462 & 0.592 & 0.538 & 0.690\end{array}$


The values for $a^{\prime}$ and $b^{\prime}$ were used in the SUBDOSA program as weighting factors for the doses calculated with Pasquill $F$ and $G$ stabilities, giving doses that correspond to the site-specific $95 \%$ centerline data.

Consequences (Shown in Table C.2)

Criteria The extremely unlikely event criteria are provided in Table C.2.

C.3 POWER ACCIDENT (See Section B.3.1.2)

Code Documentation

Computer Codes: DACRIN (Rev. 1.2, 1980) for inhalation doses SUBDOSA (3/87) for submersion doses

Calculated Doses: Acute inhalation and submersion, individual receptors at 100 and 490 meters, population dose calculated for population within $80 \mathrm{~km}, 50$-year dose commitment for inhalation doses

Files Addressed: Radionuclide Library (RMDLIB) $(1 / 15 / 81)$

Organ Data Library (2/5/81)

Energy Probability Library (3/87)

Submersion Dose Model: Finite cloud for first 8 hours of individual exposure Semi-infinite cloud for remainder of individual exposure (from 8 hours to 30 days after the initiating event) and full duration of population exposure (30 days)

As sumptions

Release Height: Ground level 


\section{TABLE C.2}

CONSEQUENCES OF AN SP-100 CORE HANDLING ACCCIDENT IN 309 BUILDING 180 DAYS AFTER SHUTDOWN UNDER VARIOUS FILTRATION SCENARIOS WITH NO HOLD UP PRIOR TO RELEASE

\begin{tabular}{|c|c|c|c|c|c|c|c|c|c|c|c|c|c|c|c|c|}
\hline \multirow[b]{3}{*}{ Filtration: } & \multicolumn{9}{|c|}{ 50-Year Inhalation Dose Commitment } & \multicolumn{3}{|c|}{ Submersion Dose } & \multirow{2}{*}{\multicolumn{3}{|c|}{ Total Dose }} & \multirow{3}{*}{$\begin{array}{l}\text { Extremely } \\
\text { Unlikely } \\
\text { Event } \\
\text { Limit }\end{array}$} \\
\hline & \multicolumn{2}{|c|}{ Halogens } & \multirow{2}{*}{$\begin{array}{l}\begin{array}{l}\text { Noble } \\
\text { Gases* }\end{array} \\
\text { None } \\
\end{array}$} & \multicolumn{2}{|c|}{ Volatile Solids } & \multicolumn{2}{|c|}{ Nonvolatile Solids } & \multicolumn{2}{|c|}{ Heavy Metals } & \multicolumn{2}{|c|}{ Halogens } & \multirow{2}{*}{$\begin{array}{l}\text { Noble } \\
\text { Gases } \\
\text { None } \\
\end{array}$} & & & & \\
\hline & None & $95 \%$ & & 1 HEPA & 2 HEPAS & 1 HEPA & 2 HEPAS & 1 HEPA & 2 HEPAS & None & $95 \%$ & & $\begin{array}{l}\text { THEPA } \\
\text { \& No Hal. }\end{array}$ & $\begin{array}{l}\text { THEPA } \\
\& 95 \% \mathrm{Hal} . \\
\end{array}$ & $\begin{array}{l}2 \text { HEPAs } \\
\& 95 \% \text { Hal. }\end{array}$ & \\
\hline $\begin{array}{l}\text { POPULATION } \\
\text { Organ } \\
\end{array}$ & rson-rem) & & & & & & & & & & & & & & & \\
\hline Whole Body & $1.1 E-3$ & $5.7 E-5 \mid$ & -- & $5.2 E+0$ & $2.6 \mathrm{E}-2$ & 2. $3 E+0$ & $1.1 E-2$ & $1.7 \mathrm{E}-1$ & $8.6 E-4$ & $2.0 E-4$ & $1.0 E-5$ & $1.3 E-1$ & $8.2 E+0$ & $8.2 E+0$ & $5.5 E-1$ & $N / A$ \\
\hline Bone & $1.1 E-3$ & $5.7 E-5$ & -- & $5.1 E+0$ & $2.6 E-2$ & $3.6 E+1$ & $1.8 E-1$ & $3.7 E+0$ & $1.8 E-2$ & $2.0 E-4$ & $1.0 E-5$ & $1.3 E-1$ & $4.5 E+1$ & $4.5 E+1$ & 7. $3 E-1$ & $N / A$ \\
\hline Lung & $1.1 E-3$ & $5.3 E-5$ & -- & $1.3 E+0$ & $6.4 E-3$ & $1.8 E+1$ & $8.8 E-2$ & $1.2 \mathrm{E}-1$ & $5.9 E-4$ & $2.0 E-4$ & $1.0 E-5$ & $1.3 E-1$ & $2.0 E+1$ & $2.0 E+1$ & 6. $1 E-1$ & N/A \\
\hline Thyroid & 7.2E-1 & $3.6 \mathrm{E}-2$ & -- & -- & -- & $3.4 E-4$ & $1.7 E-6$ & -- & -- & $2.0 E-4$ & $1.0 E-5$ & $1.3 E-1$ & $1.2 E+0$ & $5.5 E-1$ & $5.5 E-1$ & $N / A$ \\
\hline Sk in & -- & -- & -- & -- & -- & -- & -- & -- & -- & $2.8 E-4$ & $1.4 E-5$ & $1.2 E+1$ & $1.3 E+1$ & $1.3 E+1$ & $1.3 E+1$ & $N / A$ \\
\hline \multicolumn{3}{|c|}{ MAXIMUM INDIVIDUAL (rem) } & & & & & & & & & & & & & & \\
\hline Whole Body & $4.5 E-5$ & $2.2 E-6$ & -- & $2.0 E-1$ & $1.0 E-3$ & $8.9 E-2$ & $4.5 E-4$ & $6.7 E-3$ & $3.4 E-5$ & $2.7 E-7$ & $1.3 E-8$ & $1.6 E-4$ & $3.0 E-1$ & $3.0 E-1$ & $1.6 \mathrm{E}-3$ & 25 \\
\hline Bone & 4. $4 E-5$ & 2. $2 \mathrm{E}-6$ & -- & $2.0 E-1$ & $1.0 E-3$ & $1.4 E+0$ & $7.1 E-3$ & $1.4 E-1$ & $7.2 E-4$ & $2.7 E-7$ & $1.3 E-8$ & $1.6 E-4$ & $1.7 E+0$ & $1.7 E+0$ & $9.0 E-3$ & 150 \\
\hline Lung & 4. $2 E-5$ & $2.1 E-6$ & -- & $5.0 E-2$ & $2.5 E-4$ & $6.9 E-1$ & $3.4 E-3$ & $4.6 E-3$ & 2. $3 E-5$ & $2.7 E-7$ & $1.3 E-8$ & $1.6 E-4$ & $7.4 E-1$ & $7.4 E-1$ & $3.8 E-3$ & 75 \\
\hline Thyroid & $2.8 \mathrm{E}-2$ & $1.4 E-3$ & -- & -- & -- & 1. $3 E-5$ & $6.6 E-8$ & - & -- & $2.7 E-7$ & $1.3 E-8$ & $1.6 E-4$ & $2.8 E-2$ & $1.6 E-3$ & $1.6 \mathrm{E}-3$ & 150 \\
\hline Sk in & -- & -- & -- & -- & -- & -- & -- & -- & - & $1.7 E-6$ & $8.5 E-8$ & $2.6 \mathrm{E}-1$ & $2.6 E-1$ & $2.6 E-1$ & $2.6 E-1$ & 150 \\
\hline \multicolumn{3}{|c|}{ ONSITE INDIVIDUAL (rem) } & & & & & & & & & & & & & & \\
\hline Whole Body & $4.1 E-4$ & $2.1 E-5$ & -- & $1.9 E+0$ & $9.3 E-3$ & $8.1 E-1$ & $4.1 E-3$ & $6.2 E-2$ & 3. $1 E-4$ & $8.0 E-7$ & $4.0 \mathrm{E}-8$ & $4.8 E-4$ & $2.8 E+0$ & $2.8 E+0$ & $1.4 E-2$ & 100 \\
\hline Bone & 4. IE-4 & $2.0 E-5$ & -- & $1.8 E+0$ & $9.2 \varepsilon-3$ & $1.3 E+1$ & $6.5 E-2$ & $1.3 E+0$ & $6.6 \mathrm{E}-3$ & $8.0 E-7$ & $4.0 \mathrm{E}-8$ & $4.8 E-4$ & $1.6 E+1$ & $1.6 \mathrm{E}+1$ & 8.1E-2 & 600 \\
\hline Lung & $3.8 E-4$ & $1.9 \mathrm{E}-5$ & -- & $4.6 E-1$ & $2.3 E-3$ & $6.3 E+0$ & $3.1 E-2$ & $4.2 \mathrm{E}-2$ & $2.1 E-4$ & $8.0 E-7$ & $4.0 E-8$ & $4.8 E-4$ & $6.8 E+0$ & $6.8 E+0$ & $3.4 E-2$ & 300 \\
\hline Thyroid & $2.6 \mathrm{E}-1$ & $1.3 E-2$ & + & $\cdots$ & -- & $1.2 E-4$ & $6.1 E-7$ & -- & -- & $8.0 E-7$ & $4.0 E-8$ & $4.8 E-4$ & $2.6 \mathrm{E}-1$ & $1.4 E-2$ & $1.3 E-2$ & 600 \\
\hline Sk in & -- & -- & -- & -- & -- & $\cdots$ & -- & - & -- & $1.2 E-5$ & $6.0 \mathrm{E}-7$ & 2. $2 E+0$ & 2. $2 E+0$ & 2. $2 E+0$ & 2. $2 E+0$ & 600 \\
\hline
\end{tabular}

\footnotetext{
*Inhalation doses due to decay products.
}

**Hal. = Halogen. 
Meteorology:

Individual Doses: First 8 hours of release

Worst-case $95 \%$ centerline dispersion factor $(x / Q)$

for a 11 transport directions and ground level release at a wind speed of $0.78 \mathrm{~m} / \mathrm{s}:(\mathrm{C} .3)$

$$
\begin{aligned}
& \begin{array}{l}
4.3 \mathrm{E}-2 \mathrm{~s} / \mathrm{m}^{3} \text { at } 100 \mathrm{~m} \text { (onsite individual evacuated } \\
\text { after one hour) }
\end{array} \\
& 4.7 \mathrm{E}-3 \mathrm{~s} / \mathrm{m}^{3} \text { at } 490 \mathrm{~m}
\end{aligned}
$$

\section{Remainder of release}

Dispersion factors were determined by using the ratio of the 8- to 24-hour, 1- to 4-day, and 4- to 30-day dispersion factors recommended in NRC Regulatory Guide $1.3^{(C .1)}$ for ground-level releases at a distance of 490 meters, to the 0 - to 8-hour dispersion factor in the same document. The ratios were applied to the worst-case Hanford-specific $95 \%$ centerline dispersion factor used in the first 8 hours of the release $\left(4.7 E-3 \mathrm{~s} / \mathrm{m}^{3}\right)$ to obtain Hanford-specific dispersion factors for the three remaining time periods. The calculated dispersion factors for 490 meters are:

\begin{tabular}{cc}
$\begin{array}{c}\text { Dispersion } \\
\text { Factor }\left(\mathrm{s} / \mathrm{m}^{3}\right)\end{array}$ & $\begin{array}{c}\text { Time Period Foll } \\
\text { Initiating Even }\end{array}$ \\
\cline { 2 - 2 } $1.1 \mathrm{E}-3$ & $\begin{array}{c}8-24 \text { hours } \\
3.8 \mathrm{E}-4\end{array}$ \\
$9.2 \mathrm{E}-5$ & $4-4$ days \\
& $4-30$ days
\end{tabular}

Population Doses: Worst-case population-weighted 95\% sector-averaged dispersion factor $(C .3)$ for all transport directions and ground level release at a wind speed of $0.78 \mathrm{~m} / \mathrm{s}$ (dispersion factor data from Reference C.5 and 1990 population data from Reference C.6):

$$
\begin{gathered}
1.17 E-1 \text { person-s } / m^{3} \text { for duration of release } \\
\text { (30 days) }
\end{gathered}
$$


Removal Mechanisms: None

Release Time: $\quad 30$ days

Source Terms: Fission product inventories (see Table C.3) were taken from the RIBD output ${ }^{(C .7)}$ and heavy metal inventories (C.8). The RIBD data correspond to the inventories present after 2 years of operation at $8 \mathrm{MW}$ and no decay following shutdown.

All the fuel cladding is assumed to be breached in this event. Since uranium nitride is considered to be a reactive fuel type, the release fractions were assumed to be the more conservative of those for molten fuel (virtually incredible) or for a fire.

\section{Classification}

Halogens

Noble Gases

Volatile Solids

Nonvolatile Solids

Heavy Metals

\section{Release Fraction}

$$
\begin{aligned}
& 1.00 \\
& 1.00 \\
& 0.50 \\
& 0.01 \\
& 0.01
\end{aligned}
$$

The presence of large quantities of liquid metal, lithium and potentially sodium, over the core during this event will considerably reduce the quantity of halogens that might be released to the environment. It was assumed that $90 \%$ of the halogens released become chemically associated with the liquid metal. (C.10) Half of the remaining $10 \%$ of the halogens that do not become associated with the liquid metal is assumed to plate out in containment. It was also assumed that all of the liquid metal burns, producing an aerosol (including halogens) of which $90 \%$ plates out within containment. (C. 11-C.13) These assumptions lead to $14 \%$ of the halogens being available for release from containment. 
TABLE $C .3$

\section{SP-100 INVFNTORIES ( $i$ ) AFTER 2 YEARS AT 8 MW AND NO DECAY (Radionuclides Common to RMDLIB and RIBD)}

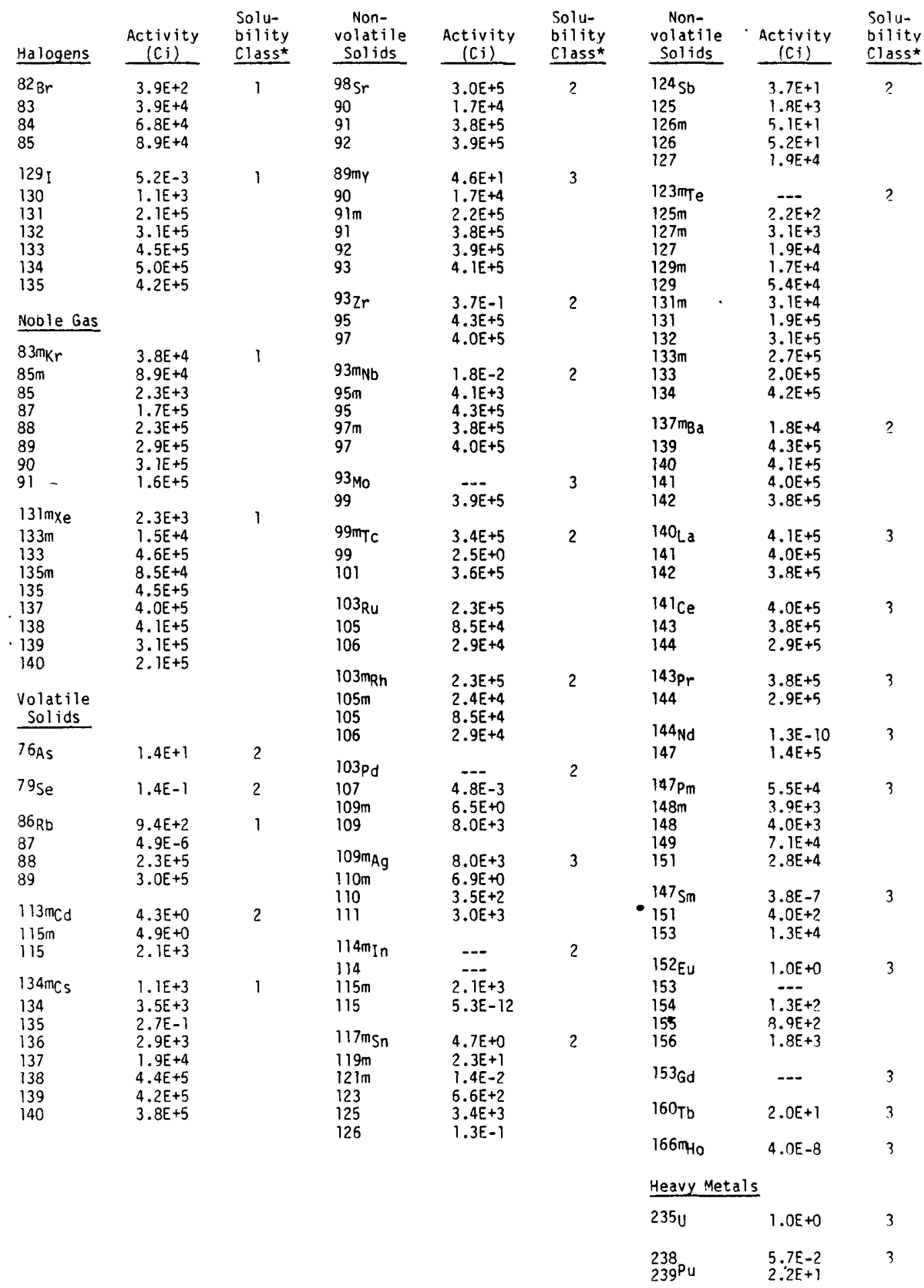

\footnotetext{
* Solubility class (lung clearance classification) assuming oxide form: 1 = cleared from lungs

in days, 2 = cleared from lungs in weeks, 3 = cleared from lungs in years (Reference $C .9$ ).
} 
Containment was assumed to be maintained such that $0.04 \%$ of the released material escapes unfiltered to the environment each day over a 30-day time period following the event, with no credit taken for reduction in leak rate over that time.

The RIBD inventories were entered into the DACRIN and SUBBDOSA runstreams with multiplication factors accounting for release and leakage fractions. For SUBDOSA, an additional factor for simulating $95 \%$ centerline stabilities was used. Derivation of these SUBDOSA factors is described in Section C.2.

Consequences (Shown in Table C.4)

Criteria The extremely unlikely event criteria are provided in Table C.4.

C.4 TRITIUM RELEASE

Code Documentation

Computer Codes: $\quad$ DACRIN (Rev. 1.2, 1980)

Calculated Doses: Acute inhalation, individual receptors at 100 and $490 \mathrm{~m}$, population dose calculated for population within $80 \mathrm{~km}, 50$-year dose commitment

Files Addressed: $\quad$ Radionuclide Library (RMDLIB) $(1 / 15 / 81)$ Organ Data Library (2/5/81)

Assumptions

Release Height: Ground level 
TABLE C. 4

CONSEQUENCES OF AN SP-100 CORE POWER ACCIDENT FAILURE IN 309 BUILDING WITH UNFILTERED $0.04 \%$ RELEASE PER DAY FOR 30 DAYS

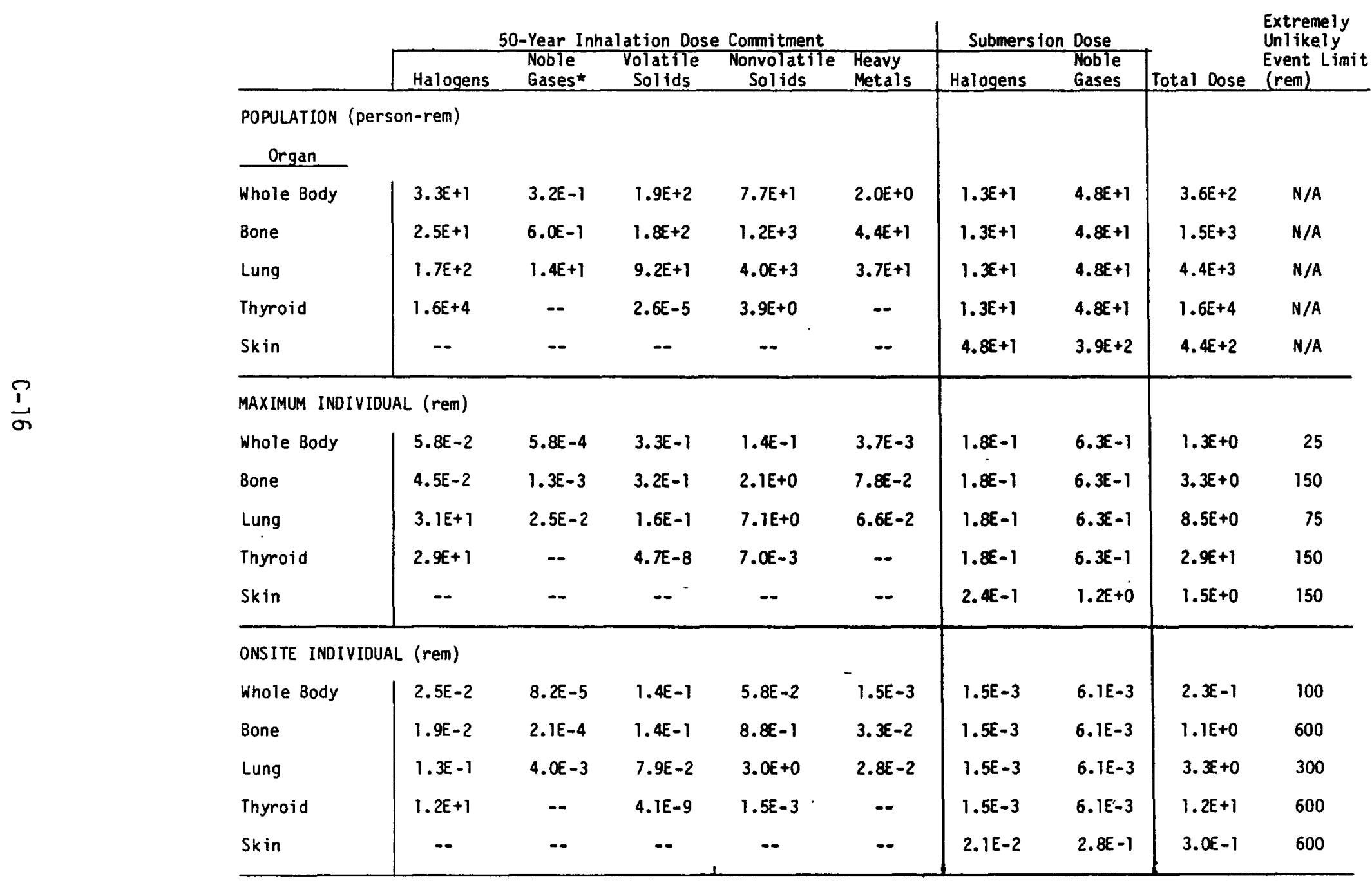

*Inhalation doses due to decay products. 
Meteorology:

Individual Doses: Worst-case $95 \%$ centerline dispersion factor $(x / Q)$ for all transport directions and ground level release at a wind speed of $0.78 \mathrm{~m} / \mathrm{s}:(C .3)$

$$
\begin{aligned}
& 4.3 \mathrm{E}-2 \mathrm{~s} / \mathrm{m}^{3} \text { at } 100 \mathrm{~m} \\
& 4.7 \mathrm{E}-3 \mathrm{~s} / \mathrm{m}^{3} \text { at } 490 \mathrm{~m}
\end{aligned}
$$

Population Doses: Worst-case population-weighted $95 \%$ sector-averaged dispersion factor for all transport directions and ground level release at a wind speed of $0.78 \mathrm{~m} / \mathrm{s}$ (dispersion factor data from Reference C.5 and 1990 population data from Reference C.6):

$$
1.17 E-1 \text { person-s } / \mathrm{m}^{3}
$$

Removal Mechanisms: None

Source Term: $\quad 1800 \mathrm{Ci}^{3} \mathrm{H}$; based on maximum inventory of tritium in Tritium Removal System canisters

Consequences

50-Year Dose Commitment

\begin{tabular}{lcccc}
\multicolumn{1}{c}{ Organ } & $\begin{array}{c}\text { Onsite } \\
\text { Individual (rem)* }\end{array}$ & & $\begin{array}{c}\text { Maximum } \\
\text { Individual (rem)* }\end{array}$ & $\begin{array}{c}\text { Population } \\
\text { (person-rem) }\end{array}$ \\
Whole Body & $2.0 \mathrm{E}+0(100)$ & & $2.2 \mathrm{E}-1 \quad(25)$ & $5.6 \mathrm{E}+0$ \\
Bone & $---(600)$ & & $---(150)$ & $-\cdots$ \\
Lung & $2.0 \mathrm{E}+0(300)$ & & $2.2 \mathrm{E}-1 \quad(75)$ & $5.6 \mathrm{E}+0$ \\
Thyroid & $2.0 \mathrm{E}+0(600)$ & & $2.2 \mathrm{E}-1(150)$ & $5.6 \mathrm{E}+0$
\end{tabular}

*Criteria for extremely unlikely events are listed in parentheses.

Criteria The extremely unlikely event criteria are provided in the previous table. 


\section{C.5 SECONDARY SYSTEM SODIUM LEAK AND FIRE}

\section{C.5.1 Alkali Metal Aerosol Concentration}

The formula for calculating offsite alkali metal aerosol concentration is:

where:

$$
C=(S)(1 / t)(x / Q)\left(F_{1}\right)\left(F_{2}\right)\left(F_{3}\right)\left(F_{4}\right)\left(F_{5}\right)
$$

$$
\begin{aligned}
C & =\text { Concentration }\left(\mathrm{mg} / \mathrm{m}^{3}\right) \\
S & =\text { Quantity of source term }(\mathrm{mg}) \\
t & =\text { Duration of release }(\mathrm{s}) \\
x / Q & =\text { Atmospheric dispersion factor }\left(\mathrm{s} / \mathrm{m}^{3}\right) \\
F_{1} & =\text { Release fraction (aerosol production fraction) } \\
F_{2} & =\text { Plateout (transmission) fraction } \\
F_{3} & =\text { Filtration (transmission) fraction } \\
F_{4} & =\text { Fraction of metal converted to hydroxide } \\
F_{5} & =\text { Molecular weight conversion factor }
\end{aligned}
$$

The values used for these variables are:

$$
\mathrm{S}=1.84 \mathrm{E}+9 \mathrm{mg} \mathrm{Na}
$$

This value is based on a 500-gal leak, a density of $970 \mathrm{mg} \mathrm{Na}$ per $\mathrm{cm}^{3}$, and a conversion factor of $10^{6} \mathrm{~cm}^{3}$ per $264.2 \mathrm{gal}$.

$$
\begin{aligned}
t & =8.82 E+3 \mathrm{~s} \text { for a spill with no fire-suppression plate } \\
t & =2.94 E+5 \mathrm{~s} \text { for a spill with fire-suppression plate* } \\
x / Q & =4.3 \mathrm{E}-2 \mathrm{~s} / \mathrm{m}^{3} \text { at } 100 \mathrm{~m} \\
x / Q & =4.7 \mathrm{E}-3 \mathrm{~s} / \mathrm{m}^{3} \text { at } 490 \mathrm{~m}
\end{aligned}
$$

*This value was derived by assuming the burn rate to be $3 \%$ of that with no fire-suppression plate. 
This value is a $95 \%$ centerline worst-case dispersion factor for all transport directions and is based on data from Reference C.3.

$$
\begin{aligned}
& F_{1}=0.26 \\
& F_{2}=0.5
\end{aligned}
$$

Alkali metal aerosol plateout ranges from 10\% to 100\%. Even though the sodium leak occurs outside containment, it will occur in a building with catch pans and fire-suppression plates. A 50\% plateout fraction was considered reasonable.

$$
F_{3}=1.0
$$

The release was assumed to be unfiltered, so no credit for filtration was taken.

$$
F_{4}=1.0
$$

All the released metal was conservatively assumed to be converted to

\begin{tabular}{|c|c|c|c|}
\hline \multirow[b]{2}{*}{$\begin{array}{l}\text { Distance } \\
(\mathrm{m})\end{array}$} & \multicolumn{3}{|c|}{ Alkali Metal Aerosol Concentration $\left(\mathrm{mg} / \mathrm{m}^{3}\right)$} \\
\hline & $\begin{array}{l}\text { With Fire } \\
\text { Suppression Plate } \\
\text { ( 8-h Duration) } \\
\end{array}$ & $\begin{array}{l}\text { Without Fire } \\
\text { Suppression Plate } \\
\text { ( } 2.5-\mathrm{h} \text { Duration) } \\
\end{array}$ & $\begin{array}{c}\text { Extremely } \\
\text { Unlikely Event } \\
\text { Limit (C.15) } \\
\end{array}$ \\
\hline 100 & 60 & 2000 & 200 \\
\hline 490 & 6.5 & 220 & 40 \\
\hline
\end{tabular}
hydroxide. This would not normally be the case.

$$
F_{5}=\frac{40 \mathrm{NaOH}}{23 \mathrm{Na}}=1.7 \text { for } \mathrm{Na}
$$

Substituting these values into the formula gives the following results:

Since fire-suppression plates will be installed, the aerosol release is acceptable. 


\section{C.5.2 Radiological Consequences}

Code Documentation

Computer Codes: $\quad$ DACRIN (Rev. 1.2, 1980) for inhalation doses

Calculated Doses: Acute inhalation, individual receptors at 100 and 490 meters, population doses calculated for population within $80 \mathrm{~km}, 50-\mathrm{yr}$ dose commitment

Files Addressed: $\quad$ Radionuclide Library (RMDLIB) $(1 / 15 / 81)$

Organ Data Library $(2 / 15 / 81)$

Assumptions

Release Height: Ground level

Meteorology:

Individual Doses: Worst-case $95 \%$ centerline dispersion factor $(x / Q)$ for all transport directions and ground level release at a wind speed of $0.78 \mathrm{~m} / \mathrm{s}$ :

$$
\begin{aligned}
& 4.3 E-2 s / m^{3} \text { at } 100 \mathrm{~m} \\
& 4.7 E-3 \mathrm{~s} / \mathrm{m}^{3} \text { at } 490 \mathrm{~m}
\end{aligned}
$$

Population Doses: Worst-case population-weighted $95 \%$ sector-averaged dispersion factor for all transport directions and ground level release at a wind speed of $0.78 \mathrm{~m} / \mathrm{s}$ (dispersion factor data from Reference C.5 and 1990 population data from Reference C.6):

$$
1.17 E-1 \text { person-s/m } 3
$$

Removal Mechanisms: None

Release Time: One hour 
Source Terms :
$43 \mathrm{Ci}^{54} \mathrm{Mn}$
$0.3 \mathrm{Ci}{ }^{60} \mathrm{Co}$
$0.3 \mathrm{Ci}^{22} \mathrm{Na}$
$43 \mathrm{Ci}^{24} \mathrm{Na}$

These activities are projected maximums present in the 500-gal sodium spill following 2 yr of operation at $8 \mathrm{MW}$. An aerosol release fraction of 26\% (based on scoping calculations) and a plateout (transmission) fraction of $50 \%$ (based on release within a closed space) were applied as multiplication factors in the DACRIN runstream.

Consequences

\begin{tabular}{lccccc}
\multicolumn{1}{c}{ Organ } & \multicolumn{2}{c}{$\begin{array}{c}\text { Onsite } \\
\text { Individual }(\mathrm{rem}) \star\end{array}$} & $\begin{array}{c}\text { Maximum } \\
\text { Individual }(\mathrm{rem}) \star\end{array}$ & $\begin{array}{c}\text { Population } \\
\text { (person-rem) }\end{array}$ \\
Whole Body & $1.9 E-1$ & $(100)$ & $2.1 E-2(25)$ & $5.3 E-1$ \\
Bone & --- & $(600)$ & $---(150)$ & --- \\
Lung & $9.6 E+0$ & $(300)$ & $1.1 E+0(75)$ & $2.7 E+1$ \\
Thyroid & --- & $(600)$ & $---(150)$ & ---
\end{tabular}

*Criteria for extremely unlikely events are listed in parentheses.

Criteria The extremely unlikely event criteria are provided in the previous table.

C.6 LITHIUM LEAK

The formula for calculating offsite alkali metal aerosol concentration is:

$$
C=(S)(1 / t)(x / Q)\left(F_{1}\right)\left(F_{2}\right)\left(F_{3}\right)\left(F_{4}\right)\left(F_{5}\right)
$$


where:

$$
\begin{aligned}
C & =\text { Concentration }\left(\mathrm{mg} / \mathrm{m}^{3}\right) \\
\mathrm{S} & =\text { Quantity of source term }(\mathrm{mg}) \\
\mathrm{t} & =\text { Duration of release }(\mathrm{s}) \\
\mathrm{X} / \mathrm{Q} & =\text { Atmospheric dispersion factor }\left(\mathrm{s} / \mathrm{m}^{3}\right) \\
F_{1} & =\text { Release fraction (aerosol production fraction) } \\
F_{2} & =\text { Plateout (transmission) fraction } \\
F_{3} & =\text { Filtration (transmission) fraction } \\
F_{4} & =\text { Fraction of metal converted to hydroxide } \\
F_{5} & =\text { Molecular weight conversion factor }
\end{aligned}
$$

The values used for these variables are:

$$
\mathrm{S}=6.06 \mathrm{E}+8 \mathrm{mg} \mathrm{Li}
$$

This value is based on a 300-gal spill that exceeds the credible spill (Appendix B), a density of $534 \mathrm{mg} \mathrm{Li}$ per $\mathrm{cm}^{3}$, and a conversion factor of $10^{6} \mathrm{~cm}^{3}$ per $264.2 \mathrm{gal}$.

$$
\begin{aligned}
t & =2.63 E+3 \text { s for a spill with no fire-suppression plate } \\
t & =8.76 E+4 \text { s for a spill with fire-suppression plate* } \\
x / Q & =4.3 E-2 \mathrm{~s} / \mathrm{m}^{3} \text { at } 100 \mathrm{~m} \\
x / Q & =4.7 E-3 \mathrm{~s} / \mathrm{m}^{3} \text { at } 490 \mathrm{~m}
\end{aligned}
$$

This value is a 95\% centerline worst-case dispersion factor for all transport directions and is based on data from Reference C. 3 .

$$
\begin{aligned}
& F_{1}=0.12 \\
& F_{2}=0.5
\end{aligned}
$$

* This value was derived by assuming the burn rate to be $3 \%$ of that with no fire-suppression plate. 
Alkali metal aerosol plateout ranges from $10 \%$ to $100 \%$. The release was assumed to occur inside containment (into catch pans with fire-suppression plates) so a $50 \%$ plateout fraction was considered reasonable.

$$
\begin{aligned}
& F_{3}=5 E-4 \text { for one HEPA stage } \\
& F_{3}=2.5 E-6 \text { for two HEPA stages }
\end{aligned}
$$

The SP-100 design process will ensure that HEPA filter loading with lithium aerosol will not be a problem, by verifying adequate filter capacity.

$$
F_{4}=1.0
$$

All the released metal was conservatively assumed to be converted to hydroxide. This would not normally be the case.

\begin{tabular}{|c|c|c|c|c|}
\hline \multirow{3}{*}{$\begin{array}{l}\text { Distance } \\
(\mathrm{m}) \\
\end{array}$} & \multicolumn{4}{|c|}{ Alkali Metal Aerosol Concentration $\left(\mathrm{mg} / \mathrm{m}^{3}\right)$} \\
\hline & $\begin{array}{c}\text { With Fire } \\
\text { Suppression } \\
\text { Plate (Duration } \\
\text { about } 24 \text { hours) }\end{array}$ & $\begin{array}{l}\text { Withou } \\
\text { Suppre } \\
\text { Plate } \\
\text { about }\end{array}$ & $\begin{array}{l}\text { ire } \\
\text { on } \\
\text { ation } \\
\text { inutes) }\end{array}$ & $\begin{array}{c}\text { Extremely } \\
\text { Unlikely Event }\end{array}$ \\
\hline & I HEPA & प1IDO & $2450 A$ & Limit (C.15) \\
\hline 100 & $1.5 E-4$ & $1.0 \mathrm{E}+0$ & $5.1 E-3$ & 200 \\
\hline 490 & $3.3 E-3$ & $1.1 \mathrm{E}-1$ & $5.5 E-4$ & 40 \\
\hline
\end{tabular}

$$
F_{5}=\frac{24 L i O H}{7 L i}=3.4 \text { for } L i
$$

Substituting these values into the formula gives the following results:

These values are well below the site boundary alkali metal aerosol criteria for extremely unlikely events. It should also be noted that fire extinguishing systems, which were not accounted for here, will reduce the duration of the release significantly. 


\section{C.7 REFERENCES}

C.1 Regulatory Guide 1.3, "Assumptions Used for Evaluating the Potential Radiological Consequences of a Loss-of-Coolant Accident for Boiling Water Reactors, "US Nuclear Regulatory Commission, Washington, DC, Rev. 2, June 1974 .

C.2 Regulatory Guide 1.4, "Assumptions Used for Evaluating the Potential Radiological Consequences of a Loss-of-Coolant Accident for Pressurized Water Reactors, "US Nuclear Regulatory Commission, Washington, DC, June 1974.

C.3 Letter, J. V. Ramsdell (PNL) to D. L. Strenge and J. S. Davis, "Special $x / Q$ Computations for the 300 and 400 Areas," August 23, 1984.

C.4 "Threshold Limit Values for Chemical Substances in Work Air Adopted by ACGIH for 1984-85, "American Conference of Governmental Industrial Hygienists (ACGIH), Cincinnati, OH, 1985.

C.5 W. D. McCormack, J. V. Ramsdell, and B. A. Napier, Hanford Dose Overview Program: Standarized Methods and Data for Hanford Environmental Dose Calculations, PNL-3777, Rev. 1, Pacific Northwest Laboratory, Richland, WA, May 1984.

C.6 D. J. Sommer, R. G. Rau, and D. C. Robinson, Population Estimates for the Areas Within a 50-Mile Radius of Four Reference Points on the Hanford Site, PNL-4010, Pacific Northwest Laboratory, Richland, WA, November 1981.

C.7 Memo, R. J. Morford (WHC) to W. L. Bunch (WHC), "Fission Products in SP-100," February 20, 1986.

C.8 Letter, C. R. Be11 (LANL) to C. M. Cox (WHC), "Safety Assessment," March 28, 1986.

C.9 ICRP Task Group on Lung Dynamics, "Deposition and Retention Models for Internal Dosimetry of the Human Respiratory Tract," Health Physics 12, pp. 173-207, 1966.

C. $10 \mathrm{H}$. A. Morewitz, Iodine Removal from Rising Bubbles in Sodium, N707TR100001, May 12, 1976.

C. 11 R. K. Hilliard et al., Results and Code Predictions for ABCOVE Aerosol Code Validation Test AB6 with Two Aerosol Species, HEDL-TME 84-19, Hanford Engineering Development Laboratory, Richland, WA, December 1984.

C.12 R. K. Hilliard et al., Results and Code Predictions for ABCOVE Aerosol Code Validation with Low Concentration $\mathrm{NaOH}$ and $\mathrm{NaI}$ Aerosol -- CSTF Test AB7, HEDL-TME 85-01, Hanford Engineering Development Laboratory, Richland, WA, October 1985.

C.13 D. W. Jeppson, Results and Code Prediction Comparisons of Lithium-Air Reaction and Aerosol Behavior Tests, HEDL-TME 85-25, Hanford Engineering Development Laboratory, Richland, WA, March 1986. 
C.14 J.C. Elder et al., "Performance of Multiple HEPA Filters Against Plutonium Aerosols," LA-5784-PR, 1/1-6/30/74.

C.15 Attached in Section C.8, "Bases for Toxicological Guidelines for Liquid Metal Aerosols." 

C. 8 LETTER REFERENCES
C.8.1 Reference C.3 from Section C.7

ร) Baftelle

Pacific Northwest Laboratories

Dale August 23, 1984

To Dennis Strenge/Janet Davis, Westinghouse Hanford

From Van Ramsdeli Var

Subject SPECIAL X/Q COMPUTATIONS FOR THE 300 AND 400 AREAS
Project Number

Internal Distribution

R Kathern

D McCormack

B Napier

$\checkmark$ Ramsdel1

File/lb

Enclosed are the $X / Q$ computations requested in Janet Davis' letter dated August 16, 1984. The computations use joint frequency distributions developed specifically for this application from meteorological data collected between March 25, 1982 and January 1, 1984. The joint frequency distributions are based on winds at each of the sites and stabilities determined at the HMS, For the elevated $X / Q$ computations, the wind speeds were adjusted to a release height of $80 \mathrm{~m}$ on the basis of the wind speed profile observed at the HMS.

I have compared the $800 \mathrm{~m} \mathrm{95 \%} \mathrm{X/Q} \mathrm{estimates} \mathrm{for} \mathrm{the} 400$ Area ground level and elevated releases assuming west winds with $X / Q$ values computed for the wind and stability classes of the joint frequency distribution and the actual joint frequency distributions. The $95 \%$ values fall in the locations expected given the frequency distributions.

The $X / Q$ values for each wind speed, stability class, distance and release height are also enclosed. They should be used to determine the mixture of atmospheric conditions associated with the $95 \% \mathrm{X} / \mathrm{Qs}$ for input to SUBDOSA. 


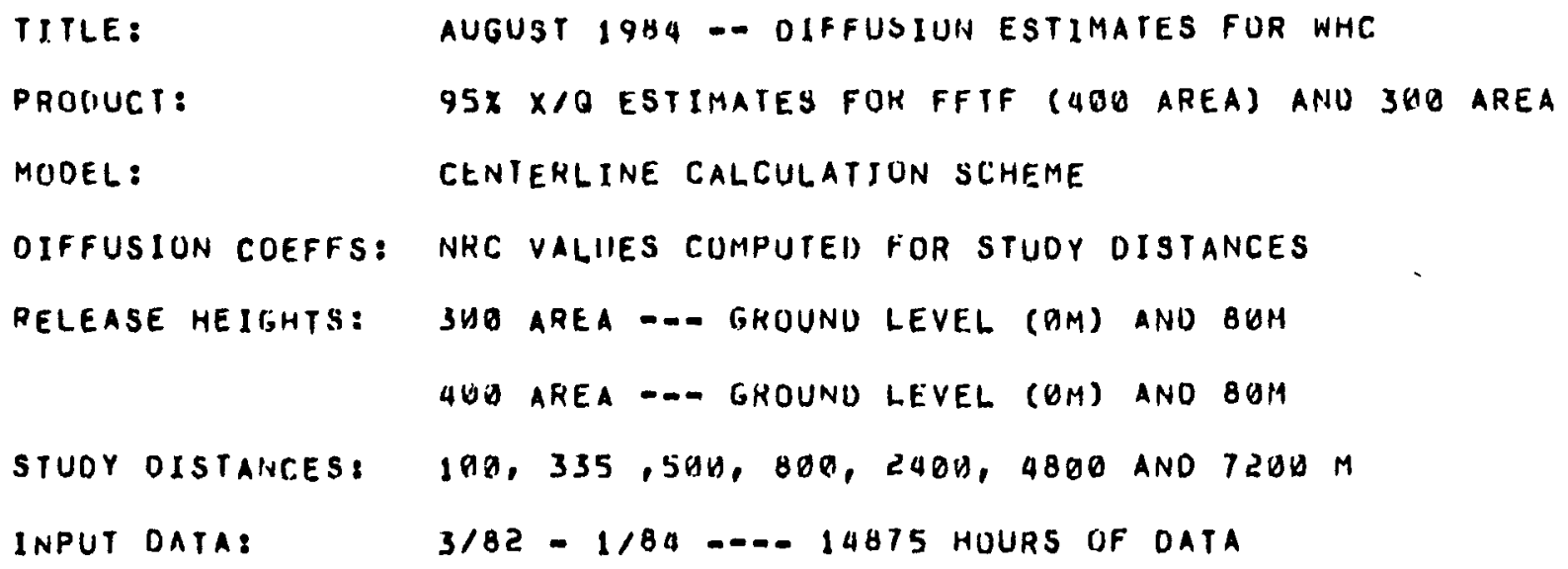




\section{AUGUST 1984 -- DIFFUSION ESTIMATES FOR WHC MESOI SITE FFTF}

THE XOQ VALUE FOR A GROUND LEVEL RELEASE THAT HAS A 0.05 PROBABILITY

OF BEING EXCEEDED -- 95\% VALUE

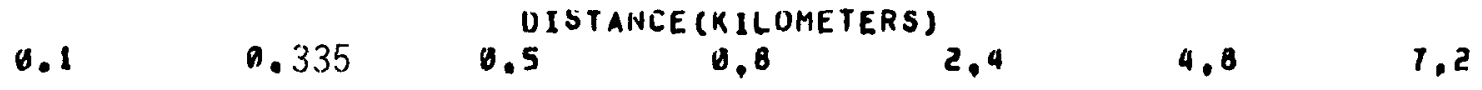

TFANSPOKT DIRECTIONB S

\begin{tabular}{|c|c|c|c|c|c|c|}
\hline $1 B E-92$ & $4.39 E-03$ & $2.34 E-D S$ & $1.06 E-03$ & $1.88 E-04$ & $1.44 E-05$ & $4.27 E-05$ \\
\hline $\begin{array}{l}\text { HANSPOHT } \\
\text {-1 } 1 \text { GE-AZ }\end{array}$ & $\begin{array}{c}\text { DIRECTION: } \\
4.7 S E-D 3\end{array}$ & $\begin{array}{l}\$ 5 W \\
2.51 E-\theta 3\end{array}$ & $1.12 E-03$ & $1.97 E-04$ & $1.80 E-05$ & $4.47 E-0$ \\
\hline $\begin{array}{l}\text { HANSPOHT } \\
\text { DIE-AL }\end{array}$ & $\begin{array}{c}\text { UIKECTION: } \\
4.4 T E-03\end{array}$ & $\begin{array}{l}5 w \\
2.36 E-03\end{array}$ & $1.07 E-03$ & $1.96 E-04$ & $1.51 E-05$ & $4.31 E-D$ \\
\hline $\begin{array}{l}\text { QANSPOKT } \\
\text { 69E-G2 }\end{array}$ & $\begin{array}{c}\text { UIKECTION: } \\
4.34 E=O 3\end{array}$ & $\begin{array}{l}\text { WS. } \\
2.2 B E-B S\end{array}$ & $1.02 E-143$ & $1.79 E-04$ & $7.06 E-05$ & $4.04 E-0$ \\
\hline $\begin{array}{l}\text { RANSPOHT } \\
\text { DIE-O2. }\end{array}$ & $\begin{array}{l}\text { UIKECTION: } \\
6.90 E-B 3\end{array}$ & $3,76 E-03$ & $1.71 E-03$ & $3,09 E-94$ & $1.22 E-114$ & $7.08 E-8$ \\
\hline $\begin{array}{l}\text { ANSHORT } \\
\text { OOE-DE }\end{array}$ & $\begin{array}{c}\text { DIHECTIUH: } \\
0.59 E-03\end{array}$ & $\begin{array}{l}\text { WNN } \\
2.4 \backslash E-D S\end{array}$ & $.01 E-03$ & $1.89 E-04$ & $7.46 E-05$ & $4.27 E-8$ \\
\hline $\begin{array}{l}\text { RAHSPOKT } \\
\text { - A2E-A2 }\end{array}$ & $\begin{array}{c}\text { DIHECTIUNS } \\
4.17 E-A 3\end{array}$ & $\begin{array}{l}\text { NW } \\
2.24 E-D !\end{array}$ & $.02 E-03$ & $1.84 E-04$ & $7.22 E-95$ & $4.15 E-0$ \\
\hline $\begin{array}{l}\text { RANSPURT } \\
\text {-2IE-AL }\end{array}$ & $\begin{array}{c}\text { DIKECIIUN: } \\
2.16 E-B 3\end{array}$ & $\begin{array}{l}N N N \\
1.5 S E-D 3\end{array}$ & $.95 E-64$ & $.33 E-04$ & $5.19 E-05$ & $3.00 E-05$ \\
\hline $\begin{array}{l}\text { HANSPOKT } \\
\text { 97E-AL }\end{array}$ & $\begin{array}{l}\text { OIRECTION: } \\
2.50 t-03\end{array}$ & N $1.36 E-U S$ & $6.37 E-04$ & $=04$ & $4.56 E-05$ & $2.63 E-05$ \\
\hline $\begin{array}{l}\text { A ISSPORT } \\
\text { SAE-DZ }\end{array}$ & $\begin{array}{l}\text { UIRECTION: } \\
\text { 2.ABE-OS }\end{array}$ & $\begin{array}{l}\text { NNE } \\
1.00 E-O S\end{array}$ & 5.10 & $17 E-05$ & $3.43 E-65$ & $1.96 E-85$ \\
\hline $\begin{array}{l}\text { IANSPORT } \\
31 E-92\end{array}$ & $\begin{array}{c}\text { DIHECIIION: } \\
2 . \forall I E-A 3\end{array}$ & $\begin{array}{l}\text { NE } \\
1.09 E-0 S\end{array}$ & 4 & $34 E-05$ & $3,62 E-05$ & $89 E-85$ \\
\hline $\begin{array}{l}\text { AHISPOKT } \\
\triangle 6 E-92\end{array}$ & $\begin{array}{c}\text { UIKECTIUNA } \\
3.80 E-A 3\end{array}$ & $\begin{array}{l}\text { ENE } \\
2.12 E=03\end{array}$ & 4 & $1.77 E-84$ & $6.94 E=05$ & $9,00 E-05$ \\
\hline $\begin{array}{l}\text { RASPPIST } \\
33 E-H 2\end{array}$ & $\begin{array}{c}\text { UIKECT TOH, } \\
3.58 E-A 3\end{array}$ & E $1.98 E-03$ & $9.13 E-04$ & $1.70 E-04$ & $6.64 E-85$ & $3.83 \mathrm{E}=\mathrm{HS}$ \\
\hline $\begin{array}{l}\text { KAPISPONT } \\
.14 E-A 2\end{array}$ & $\begin{array}{l}\text { DIRECTIUN: } \\
2.12 E-B]\end{array}$ & $\begin{array}{l}\text { ESE } \\
1.09 E-03\end{array}$ & $5.35 E-84$ & $9.23 E-015$ & $3.50 E-65$ & $2.01 E-05$ \\
\hline $\begin{array}{l}\text { ANSPORT } \\
32 E-92\end{array}$ & $\begin{array}{l}\text { UIAECTIOHS } \\
\text { Z.AQE-OS }\end{array}$ & SE & 84 & $9,35 E-05$ & $3,63 E-65$ & $2,09 E-65$ \\
\hline $\begin{array}{l}\text { IANSPORT } \\
\text { IAE - PD }\end{array}$ & $\begin{array}{c}\text { UIRECIIION } \\
3.79 E-A 3\end{array}$ & $\begin{array}{l}\text { SSE } \\
2.07 E-U S\end{array}$ & $9.54 E-04$ & $1.75 E-84$ & $0,84 E-05$ & $3.94 E-05$ \\
\hline
\end{tabular}




\section{AUGUST 1984 -- DIFFUSION ESTIMATES FOR WHC MESOI SITE FFTF}

THE XOQ VALUE FOR A $80 \mathrm{M}$ LEVEL RELEASE THAT HAS A 0.05 PROBABILITY OF BEING EXCEEDED -- 95\% VALUE

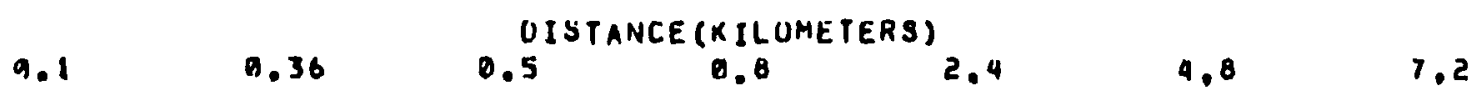

\begin{tabular}{|c|c|c|c|c|c|c|}
\hline $\begin{array}{l}\text { TRANSPONT } \\
\text { 2. } A G E-11\end{array}$ & $\begin{array}{c}\text { OIRECTIOH: } \\
\text { I.12E-AS }\end{array}$ & S $1 ., 0 D E-D S$ & $0.04 E-06$ & $1.28 E-05$ & $1.03 E-05$ & $7.0 O E-D 6$ \\
\hline $\begin{array}{l}\text { TRANSPDRT } \\
3.37 E-11\end{array}$ & $\begin{array}{l}\text { UIRECTIUN: } \\
\text { I.30E-OS }\end{array}$ & $\begin{array}{l}S 5 W \\
2.20 E-O S\end{array}$ & $1.57 E-05$ & $1.60 E-85$ & $1.05 E-05$ & $6.73 E-06$ \\
\hline $\begin{array}{l}\text { THANSPIJHT } \\
5.59 E-11\end{array}$ & $\begin{array}{c}\text { OIRECIJ ON. } \\
2.27 E-05\end{array}$ & $\begin{array}{l}3 W \\
2.94 E-65\end{array}$ & $2.65 E-05$ & $1.57 E-B 5$ & $1.06 E-05$ & $6.71 E-06$ \\
\hline $\begin{array}{l}\text { TRANBPOHT } \\
9.38 E-11\end{array}$ & $\begin{array}{l}\text { DIRECIIION } \\
3.69 E-D 5\end{array}$ & $\begin{array}{l}\text { WSW } \\
\text { S.01E-GS }\end{array}$ & $2.66 E-95$ & $1.61 E-05$ & $1.09 E-05$ & $6.71 E-86$ \\
\hline $\begin{array}{l}\text { TRANBPOHT } \\
5.03 E-11\end{array}$ & $\begin{array}{l}\text { UIRECTION: } \\
1.94 E-35\end{array}$ & W $2.82 E-45$ & $2.63 E-65$ & $1.47 E-05$ & $1.07 E-05$ & $7.26 E-66$ \\
\hline $\begin{array}{l}\text { TRANSPOKT } \\
5.82 E-11\end{array}$ & $\begin{array}{l}\text { OIKECTION: } \\
2.63 E-D 5\end{array}$ & $\begin{array}{l}\text { WINY } \\
3, U A E-O S\end{array}$ & $2.66 E-05$ & $1.61 E-05$ & $1.10 E-105$ & $6.87 E-80$ \\
\hline $\begin{array}{l}\text { TRANSPORT } \\
4.38 E-11\end{array}$ & $\begin{array}{l}\text { UIRECTIUN: } \\
\text { I. } 49 E-05\end{array}$ & $\stackrel{N / A}{2 . T 7 E-Q S}$ & $2.63 E-05$ & $1.60 E-65$ & $1.11 E-85$ & $7.48 E-86$ \\
\hline $\begin{array}{l}\text { TKANSPOKT } \\
1.20 E-11\end{array}$ & $\begin{array}{l}\text { DIHECTION: } \\
\text { I.JIE-OS }\end{array}$ & LIVN & $1.62 E-185$ & $1,39 E-165$ & $1.82 E-85$ & $6.63 E-06$ \\
\hline $\begin{array}{l}\text { TRANSPORT } \\
4.76 E-12\end{array}$ & $\begin{array}{c}\text { DIHECTIUN } \\
6.59 E-80\end{array}$ & N.HNE-US & $8,54 E-06$ & $1.2 U E-05$ & $1.41 E-45$ & $6.66 E-06$ \\
\hline $\begin{array}{l}\text { TRANSPOKT } \\
1.72 E-11\end{array}$ & $\begin{array}{l}\text { UIKECIIION: } \\
7,95 E-06\end{array}$ & $\begin{array}{l}\text { NNE } \\
9.51 E-06\end{array}$ & $8.28 E-06$ & $1.81 E-85$ & $6.91 E-86$ & $6.34 E-86$ \\
\hline $\begin{array}{l}\text { TRANSPORT } \\
1.26 E-11\end{array}$ & $\begin{array}{l}\text { UIRECIJUN: } \\
6.32 E-8.6\end{array}$ & $\stackrel{N E}{9.03 E-900}$ & $0.26 E-06$ & $1.4 B E-D S$ & $1.03 E-05$ & $6.64 E-06$ \\
\hline $\begin{array}{l}\text { TRANSPOHT } \\
1.5 T E-11\end{array}$ & $\begin{array}{l}\text { UIRECTION } \\
7.91 E-D 6\end{array}$ & $\begin{array}{l}\text { ENE } \\
0.68 E-06\end{array}$ & $0.18 E-86$ & $1.41 E-05$ & $1.11 E-B S$ & $0.28 E-06$ \\
\hline $\begin{array}{l}\text { TRANSPOHT } \\
\text { 1.2UE-11 }\end{array}$ & $\begin{array}{l}\text { OIKECTIONI } \\
5.92 E-00\end{array}$ & $E, 1.47 E-60$ & $6.24 E-86$ & $1.37 E-65$ & $1.03 E+85$ & $6.68 E-06$ \\
\hline $\begin{array}{l}\text { THANSPOHT } \\
9.47 E-16\end{array}$ & $\begin{array}{l}\text { DIRECIIIONI } \\
2.04 E-O 6\end{array}$ & $\begin{array}{l}E S t \\
4.30 E-00\end{array}$ & $4.07 E-06$ & $1.23 E-05$ & $9.60 E-06$ & $6.54 E-06$ \\
\hline $\begin{array}{l}\text { TRAVSPORT } \\
7.56 E-16\end{array}$ & $\begin{array}{l}\text { DIRECTION: } \\
\text { I.63E-O6 }\end{array}$ & $3.00 E-000$ & $4.02 E-86$ & $1.06 E-05$ & $7.75 E-66$ & $6.42 E-06$ \\
\hline $\begin{array}{l}\text { TRANSPOKT } \\
\text { 2.AAE- } 12\end{array}$ & $\begin{array}{c}\text { OIRECTIOH: } \\
5.21 E-06\end{array}$ & $\begin{array}{l}33 E \\
9.84 E-00\end{array}$ & $8.40 E-86$ & $1.40 E-05$ & $1.05 E-05$ & $6.78 E-166$ \\
\hline
\end{tabular}




\section{AUGUST 1984 -- DIFFUSION ESTIMATES FOR WHC MESOI SITE 300A}

THE XOQ VALUE FOR A GROUND LEVEL RELEASE THAT HAS A 0.05 PROBABILITY OF BEING EXCEEDED -- 95\% VALUE

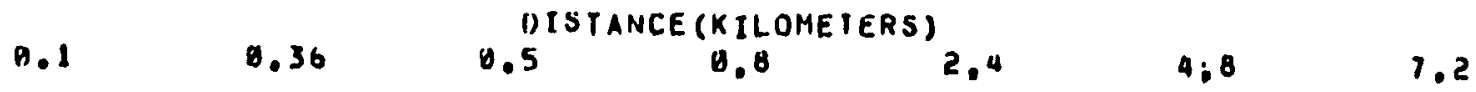

THANSPRKT DIRECTION: S

2.33E-02 2.83E- 33 1. $04 E-03$ 5.14E-04 9.35E-65 3.63E-05 2.09E-05

THANSPOHT UIHECIION: SSA

1.12E-H2 $1.36 E-03$ 1.62E-04 3.69E-04 5.43E-05 2.07E-05 1.17E-65

TFANSHOAT HIKECIIUN: SN

2.A1E-HZ 2.02E-03 1.08E-BS 5.13E-04 9.15E-05 3.41E-05 1.95E-A5

TRARSSPOHT OIRECTIONI WYW

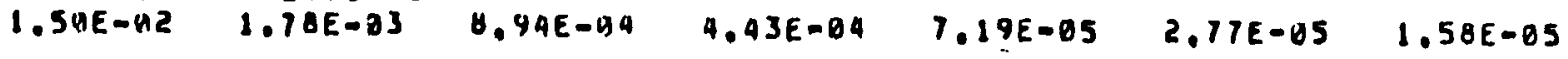

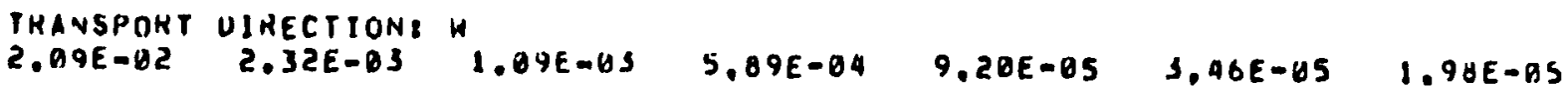

TRANSPOKT DIRECTION: WNIN

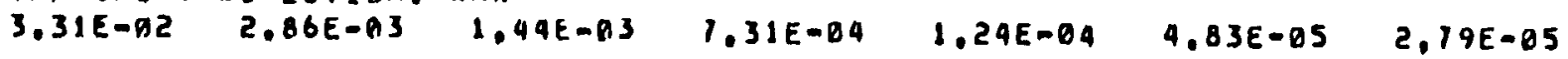

TRANSPORT DIRECTION: NW

4.2AE-HE Q.A3E-03 2.18E-AS 9.94E-DA 1.00E-04 T.08E-05 4.01E-05

TKAHSPOKT UIHECTION: NINW

4.22E-62 4.54E-83 2.41E-0S 1.08E-03 1.92E-04 7.58E-05 4.35E-05

TRAMSPORT UIRECTIUN: $N$

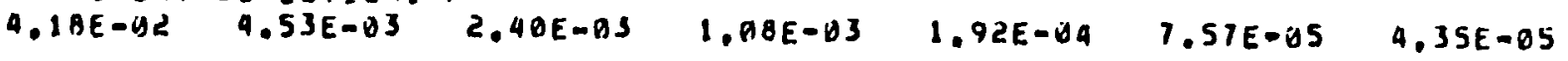

TRANSPOKT UIHECTION, NNE

\begin{tabular}{|c|c|c|c|c|c|c|}
\hline $2.97 E-82$ & $3.55 E-03$ & $1.95 E-0.9$ & $9.13 E-04$ & $1.68 E-04$ & $6.54 E-05$ & $3.77 E-05$ \\
\hline $\begin{array}{l}\text { THANSPOKT } \\
2.9 \forall E-02\end{array}$ & $\begin{array}{l}\text { UIHECTION, } \\
3.6 B E-U 3\end{array}$ & $\begin{array}{l}N E \\
2.02 E-b 3\end{array}$ & $9.35 E-84$ & $1.72 E-04$ & $6.73 E-05$ & $3.88 E-45$ \\
\hline $\begin{array}{l}\text { TRAHSPORT } \\
3.45 E-92\end{array}$ & $\begin{array}{c}\text { DIRECIIIONI } \\
4.19 E-03\end{array}$ & $\begin{array}{l}\text { ENE } \\
2.25 E-0 S\end{array}$ & $1.02 E-03$ & $1.84 E-04$ & $7.24 E-05$ & $4.16 E-05$ \\
\hline $\begin{array}{l}\text { TRANSHOKT } \\
\text { 4.2ZE-U2 }\end{array}$ & $\begin{array}{l}\text { OIKECTION: } \\
7.5 B E-O 3\end{array}$ & E. 12E-OS & $1.88 E-\theta 3$ & $3,42 E-84$ & $1.34 E-04$ & $7.73 E-05$ \\
\hline $\begin{array}{l}\text { TAANSPOHT } \\
\text { Q.2 } 2 \text { - }\end{array}$ & $\begin{array}{l}\text { DIHECIION: } \\
\text { B.6TE-OS }\end{array}$ & $\begin{array}{l}\text { ESE } \\
4.74 E-U S\end{array}$ & $2,18 E-10 S$ & $3.99 E-64$ & $1.56 E-94$ & $9.01 E-45$ \\
\hline $\begin{array}{l}\text { TRAHSPOKT } \\
\text { A. } 1 \text { GE-OC }\end{array}$ & $\begin{array}{l}\text { UIHECIION: } \\
\text { 4.7OE-OS }\end{array}$ & $2.48 E-103$ & $1.11 E-03$ & $1.96 E-04$ & $7.74 E-05$ & $4.94 E-05$ \\
\hline $\begin{array}{l}\text { TKAHSPOKT } \\
2.86 E=82\end{array}$ & $\begin{array}{l}\text { DIKECIIUN: } \\
2.91 E-03\end{array}$ & $\begin{array}{l}\text { SSE } \\
1.39 E-O S\end{array}$ & $7.44 E-B) 4$ & $1,20 E-04$ & $4.66 E-05$ & $2.69 E-05$ \\
\hline
\end{tabular}




\section{AUGUST 1984 -- DIFFUSION ESTIMATES FOR WHC MESOI SITE 300A}

THE XOQ VALUE FUR A 80 M LEVEL RELEASE THAT HAS A 0.05 PROBABILITY OF BEING EXCEEDED -- 95\% VALUE

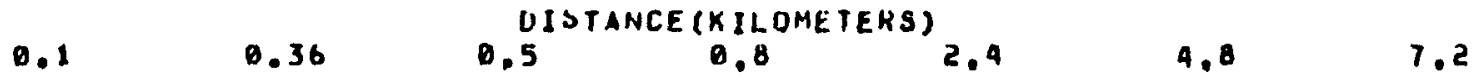

\begin{tabular}{|c|c|c|c|c|c|c|}
\hline $\begin{array}{l}\text { TRANSPOKT } \\
1.22 E-11\end{array}$ & $\begin{array}{l}\text { DIRECTION: } \\
5.73 E-80\end{array}$ & S $1.25 E-B O$ & $8.26 E-86$ & $1.09 E-85$ & $8.46 E-156$ & $6.45 E-86$ \\
\hline $\begin{array}{l}\text { RANSPOHT } \\
\text {. I3E-11 }\end{array}$ & $\begin{array}{l}\text { UIKECTION: } \\
\text { I.36E-DS }\end{array}$ & $\begin{array}{l}\text { SSA } \\
2.11 E-B S\end{array}$ & $1.09 E-05$ & $1.13 E-05$ & $5,62 E-86$ & $5.06 E-46$ \\
\hline $\begin{array}{l}\text { RANSPOKT } \\
\text { - AGE-11 }\end{array}$ & $\begin{array}{l}\text { ULHECIION: } \\
2 . U 1 E-O S\end{array}$ & $\begin{array}{l}3 W \\
2.53 E-9 S\end{array}$ & $1.85 E-05$ & $1.32 E-05$ & $8.49 E-06$ & $6.49 E-06$ \\
\hline $\begin{array}{l}\text { HANSPORT } \\
\text {-1TE-11 }\end{array}$ & $\begin{array}{l}\text { UIKECTJUN: } \\
2.70 E-B S\end{array}$ & $\begin{array}{l}\text { WS.N } \\
3.66 E-05\end{array}$ & $.67 E-05$ & $1.55 E-05$ & $1.05 E-05$ & $6.61 E-06$ \\
\hline $\begin{array}{l}\text { RAHISPORT } \\
.76 E-11\end{array}$ & $\begin{array}{l}\text { OIRECIION: } \\
2.90 E-O S\end{array}$ & W. SOE-US & $2.66 E-05$ & $1.46 E-05$ & $1.07 E-05$ & $6.73 E-06$ \\
\hline $\begin{array}{l}\text { RANS } \\
.616\end{array}$ & $\begin{array}{r}\text { UIKECT } \\
1.37 E\end{array}$ & $\begin{array}{l}H N W \\
2.37 E-0 S\end{array}$ & $2.36 E-05$ & $1.9 B E-05$ & $1,10 E-05$ & $7.93 E-\Delta 6$ \\
\hline $\begin{array}{l}\text { TRANSPQRT } \\
6.65 E-12\end{array}$ & $\begin{array}{l}\text { UIRECTION: } \\
\text { I.ARE-DS }\end{array}$ & $N W$ & $0.72 E-66$ & $1.51 E-05$ & $1.06 E-05$ & $6.73 E-86$ \\
\hline $\begin{array}{l}\text { TRANSPOKT } \\
\text { I.OIE-11 }\end{array}$ & $\begin{array}{l}\text { DIKECT TON } \\
1.19 E-65\end{array}$ & $\begin{array}{l}\text { NNW } \\
1.36 \mathrm{E}-0 \mathrm{~S}\end{array}$ & $.88 E-06$ & $.51 E-05$ & $1.09 E-05$ & $8.06 E-0106$ \\
\hline $\begin{array}{l}\text { TRANS } \\
1.89 E\end{array}$ & $\begin{array}{l}\text { UIKECIIUN: } \\
7.43 E-B 6\end{array}$ & N $9.95 E-06$ & $8.53 E-06$ & $1.55 E-05$ & $1,10 E-95$ & $7.92 E-016$ \\
\hline $\begin{array}{l}\text { TRANSPOKT } \\
1.6 Q E-11\end{array}$ & $\begin{array}{l}\text { DIKECIION: } \\
7.05 E-96\end{array}$ & $\begin{array}{l}\text { NNE } \\
\text { Y. B3E-OD }\end{array}$ & $0.34 E-06$ & $1,15 E-05$ & $9.61 E-06$ & $6.59 E=06$ \\
\hline $\begin{array}{l}\text { TRANSFOKI } \\
1.62 E-11\end{array}$ & $\begin{array}{l}\text { DIKECYION: } \\
\text { B. TAE-DG }\end{array}$ & $\begin{array}{l}N E \\
0.98 E-06\end{array}$ & $5.47 E-\not 16$ & $1.05 E-05$ & $1.00 E-115$ & $6.66 E-156$ \\
\hline $\begin{array}{l}\text { TRANSPORT } \\
1.66 E-11\end{array}$ & $\begin{array}{l}\text { OIRECTION: } \\
\text { T. B9E-B6 }\end{array}$ & $\begin{array}{l}\text { ENE } \\
7.6 \Delta E-D O\end{array}$ & $4.69 E-106$ & $1,37 E-05$ & $1.04 E-05$ & $6.69 E-86$ \\
\hline $\begin{array}{l}\text { TRANSPORT } \\
2,11 E-15\end{array}$ & $\begin{array}{l}\text { UIHECTION: } \\
2.54 E-\triangle 6\end{array}$ & $E_{5.50 E-00}$ & $7.52 E-96$ & $1.57 E-05$ & $1.12 E-05$ & $0.49 E-566$ \\
\hline $\begin{array}{l}\text { TRANGPOHT } \\
5.26 E-15\end{array}$ & $\begin{array}{l}\text { OIRECTION: } \\
4.57 E-A 6\end{array}$ & $\begin{array}{l}E S E \\
4.9 D E-O D\end{array}$ & -06 & $1.61 E-05$ & $1.13 E-05$ & $8.70 E-06$ \\
\hline $\begin{array}{l}\text { TRANSPOKT } \\
5.54 E-25\end{array}$ & $\begin{array}{c}\text { UIKECTIUN: } \\
\text { T.6TE-OI }\end{array}$ & SE & $3.92 E-06$ & $1.45 E-05$ & $1.04 E=05$ & $6.97 E-06$ \\
\hline $\begin{array}{l}\text { TRANSPOKT } \\
2.23 E-25\end{array}$ & $\begin{array}{c}\text { DIRECTIUNI } \\
3.0 B E-O T\end{array}$ & $\begin{array}{l}\text { YSE } \\
3 . \text { S. }\end{array}$ & AE & $51 E-05$ & $E=05$ & $0.0<$ \\
\hline
\end{tabular}


FFUGFAM TO COMFUTE XOQ FOF ALL STAEILITIES AND WIND SFCED CLASSES AT HANFORD FOF SELECTED DISTANCES.... NFC DIFFUSIOH COEFFICIENTS AFE USED, AS IS A GAUSSIAN, GFIOUND-LEVEL. CENTEF LINE MODEL.

SIGNA Y

$\begin{array}{rcrrrrrrr}\text { DIST. } & 1 & 2 & 3 & 4 & 5 & 6 & 7 \\ 100 & 23.4 & 17.6 & 13.4 & 9.4 & 6.7 & 4.6 & 3.1 \\ 335 & 69.8 & 52.5 & 39.8 & 28.1 & 19.9 & 13.8 & 9.2 \\ 500 & 100.2 & 75.3 & 57.2 & 40.3 & 28.6 & 19.8 & 13.2 \\ 800 & 153.1 & 115.2 & 87.4 & 61.6 & 43.8 & 30.2 & 20.1 \\ 2400 & 413.0 & 310.6 & 235.8 & 166.1 & 118.1 & 81.5 & 54.3 \\ 4800 & 772.3 & 580.8 & 441.0 & 310.6 & 220.8 & 152.4 & 101.5 \\ 7200 & 1113.8 & 837.6 & 636.1 & 447.9 & 318.5 & 219.8 & 146.5\end{array}$

SIGMA 2

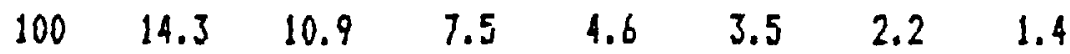
$\begin{array}{llllllll}335 & 61.8 & 33.7 & 22.6 & 13.3 & 9.6 & 6.0 & 3.6\end{array}$ $\begin{array}{llllllll}500 & 123.6 & 51.5 & 32.5 & 18.4 & 13.0 & 8.2 & 5.0\end{array}$ $\begin{array}{llllllll}800 & 294.0 & 86.0 & 49.9 & 26.6 & 18.3 & 11.7 & 7.1\end{array}$ $\begin{array}{llllllll}2400 & 2863.7 & 285.0 & 135.7 & 56.9 & 38.3 & 24.7 & 13.5\end{array}$ $\begin{array}{llllllll}4800 & 9999.9 & 607.9 & 255.1 & 87.0 & 55.3 & 34.4 & 19.2\end{array}$ $\begin{array}{llllllll}7200 & 9999.9 & 947.6 & 369.1 & 110.2 & 67.0 & 40.7 & 22.9\end{array}$ 
XOQ FOFi A DISTANCE OF $100 \mathrm{M}$

$\begin{array}{lccccccc}\text { SPEED } & 1 & 2 & 3 & 5 \text { STABILITY } & 5 & 6 & 7 \\ 0.78 & 1.22 E-03 & 2.13 E-03 & 4.07 E-03 & 9.51 E-03 & 1.75 E-02 & 3.93 E-02 & 9.74 E-02 \\ 2.48 & 3.83 E-04 & 6.70 E-04 & 1.28 E-03 & 2.99 E-03 & 5.49 E-03 & 1.24 E-02 & 3.06 E-02 \\ 4.49 & 2.12 E-04 & 3.70 E-04 & 7.07 E-04 & 1.65 E-03 & 3.03 E-03 & 6.83 E-03 & 1.69 E-02 \\ 6.95 & 1.37 E-04 & 2.39 E-04 & 4.57 E-04 & 1.07 E-03 & 1.96 E-03 & 4.41 E-03 & 1.09 E-02 \\ 9.63 & 9.87 E-05 & 1.72 E-04 & 3.30 E-04 & 7.70 E-04 & 1.41 E-03 & 3.18 E-03 & 7.89 E-03 \\ 12.54 & 7.58 E-05 & 1.32 E-04 & 2.53 E-04 & 5.92 E-04 & 1.09 E-03 & 2.44 E-03 & 6.06 E-03 \\ 15.67 & 6.07 E-05 & 1.06 E-04 & 2.03 E-04 & 4.73 E-04 & 8.70 E-04 & 1.96 E-03 & 4.05 E-03 \\ 17.88 & 5.32 E-05 & 9.29 E-05 & 1.78 E-04 & 4.15 E-04 & 7.62 E-04 & 1.71 E-03 & 4.25 E-03\end{array}$

XOQ FOF A DISTANCE OF SES M

$\begin{array}{rccccccc}\text { SFEED } & 1 & 2 & 3 & \text { STAEILITY } & 5 & 6 & 7 \\ 0.78 & 9.46 E-05 & 2.31 E-04 & 4.54 E-04 & 1.09 E-03 & 2.14 E-03 & 4.94 E-03 & 1.22 E-02 \\ 2.48 & 2.98 E-05 & 7.25 E-05 & 1.43 E-04 & 3.43 E-04 & 6.72 E-04 & 1.555-03 & 3.85 E-03 \\ 4.49 & 1.64 E-05 & 4.01 E-05 & 7.89 E-05 & 1.90 E-04 & 3.71 E-04 & 8.58 E-04 & 2.13 E-03 \\ 6.95 & 1.06 E-05 & 2.59 E-05 & 5.10 E-05 & 1.22 E-04 & 2.40 E-04 & 5.54 E-04 & 1.37 E-03 \\ 9.63 & 7.66 E-06 & 1.87 E-05 & 3.69 E-05 & 8.94 E-05 & 1.73 E-04 & 4.00 E-04 & 9.92 E-04 \\ 12.54 & 5.89 E-06 & 1.43 E-05 & 2.82 E-05 & 6.79 E-05 & 1.33 E-04 & 3.07 E-04 & 7.62 E-04 \\ 15.67 & 4.71 E-06 & 1.15 E-05 & 2.26 E-05 & 5.43 E-05 & 1.06 E-04 & 2.46 E-04 & 6.10 E-04 \\ 17.88 & 4.13 E-06 & 1.01 E-05 & 1.92 E-05 & 4.76 E-05 & 9.32 E-05 & 2.15 E-04 & 5.34 E-04\end{array}$


GROUND LEVEL RELEASE

XOQ FOF A DISTANCE OF $500 \mathrm{~m}$

$\begin{array}{cccccccc}\text { SPEED } & 1 & 2 & 3 & \text { STABILITY } & 5 & 6 & 7 \\ 0.78 & 3.30 E-05 & 1.05 E-04 & 2.20 E-04 & 5.51 E-04 & 1.10 E-03 & 2.52 E-03 & 6.25 E-03 \\ 2.48 & 1.04 E-05 & 3.31 E-05 & 6.91 E-05 & 1.73 E-04 & 3.46 E-04 & 7.92 E-04 & 1.97 E-03 \\ 4.49 & 5.73 E-06 & 1.83 E-05 & 3.81 E-05 & 9.57 E-05 & 1.91 E-04 & 4.38 E-04 & 1.09 E-03 \\ 6.95 & 3.70 E-06 & 1.18 E-05 & 2.46 E-05 & 6.18 E-05 & 1.23 E-04 & 2.83 E-04 & 7.02 E-04 \\ 9.63 & 2.67 E-06 & 8.52 E-06 & 1.78 E-05 & 4.46 E-05 & 8.90 E-05 & 2.04 E-04 & 5.06 E-04 \\ 12.54 & 2.05 E-06 & 6.54 E-06 & 1.37 E-05 & 3.43 E-05 & 6.84 E-05 & 1.57 E-04 & 3.89 E-04 \\ 15.67 & 1.64 E-06 & 5.24 E-06 & 1.09 E-05 & 2.74 E-05 & 5.47 E-05 & 1.25 E-04 & 3.11 E-04 \\ 17.88 & 1.44 E-06 & 4.59 E-06 & 9.58 E-06 & 2.40 E-05 & 4.80 E-05 & 1.10 E-04 & 2.73 E-04\end{array}$

XOQ FOF A DISTANCE OF $800 \mathrm{M}$

$\begin{array}{rccccccc}\text { SPEED } & 1 & 2 & 3 & 5 T A Y I L I T Y & 5 & 6 & 7 \\ 0.78 & 9.07 E-06 & 4.12 E-05 & 9.36 E-05 & 2.50 E-04 & 5.09 E-04 & 1.15 E-03 & 2.85 E-03 \\ 2.48 & 2.85 E-06 & 1.30 E-05 & 2.94 E-05 & 7.85 E-05 & 1.60 E-04 & 3.61 E-04 & 8.97 E-04 \\ 4.49 & 1.57 E-06 & 7.16 E-06 & 1.63 E-05 & 4.34 E-05 & 8.04 E-05 & 2.00 E-04 & 4.95 E-04 \\ 6.95 & 1.02 E-06 & 4.62 E-06 & 1.05 E-05 & 2.80 E-05 & 5.71 E-05 & 1.29 E-04 & 3.20 E-04 \\ 9.63 & 7.34 E-07 & 3.34 E-06 & 7.58 E-06 & 2.02 E-05 & 4.12 E-05 & 9.31 E-05 & 2.31 E-04 \\ 12.54 & 5.64 E-07 & 2.56 E-06 & 5.82 E-06 & 1.55 E-05 & 3.17 E-05 & 7.15 E-05 & 1.77 E-04 \\ 15.67 & 4.51 E-07 & 2.05 E-06 & 4.66 E-06 & 1.24 E-05 & 2.53 E-05 & 5.72 E-05 & 1.42 E-04 \\ 17.68 & 3.95 E-07 & 1.80 E-06 & 4.08 E-06 & 1.09 E-05 & 2.22 E-05 & 5.01 E-05 & 1.24 E-04\end{array}$


GROUND LEVEL RELEASE

YOO FOFi A DISTANICE OF $2400 \mathrm{M}$

$\begin{array}{rccccccc}\text { SPEED } & 1 & 2 & 3 & \text { STABILITY } & 5 & 6 & 7 \\ 0.78 & 3.45 E-07 & 4.61 E-06 & 1.28 E-05 & 4.32 E-05 & 9.03 E-05 & 2.03 E-04 & 5.555 E-04 \\ 2.48 & 1.09 E-07 & 1.45 E-06 & 1.01 E-06 & 1.36 E-05 & 2.84 E-05 & 6.38 E-05 & 1.75 E-04 \\ 4.49 & 5.99 E-08 & 8.01 E-07 & 2.25 E-06 & 7.50 E-06 & 1.57 E-05 & 3.53 E-05 & -9.64 E-05 \\ 6.95 & 3.87 E-08 & 5.17 E-07 & 1.43 E-06 & 4.85 E-06 & 1.01 E-05 & 2.26 E-05 & 6.23 E-05 \\ 9.63 & 2.80 E-08 & 3.73 E-07 & 1.03 E-06 & 3.50 E-06 & 7.31 E-06 & 1.64 E-05 & 4.49 E-05 \\ 12.54 & 2.15 E-08 & 2.87 E-07 & 7.93 E-07 & 2.69 E-06 & 5.62 E-06 & 1.26 E-05 & 3.45 E-05 \\ 15.67 & 1.72 E-08 & 2.29 E-07 & 6.35 E-07 & 2.15 E-06 & 4.49 E-06 & 1.01 E-05 & 2.76 E-05 \\ 17.88 & 1.51 E-08 & 2.01 E-07 & 5.56 E-07 & 1.89 E-06 & 3.94 E-06 & 8.85 E-06 & 2.42 E-05\end{array}$

XOQ. FOF A DISTANCE OF $4800 \mathrm{M}$

$\begin{array}{rccccccc}\text { SPEED } & 1 & 2 & 3 & 4 \text { STABILITY } & 5 & 6 & 7 \\ 0.78 & 5.28 E-08 & 1.16 E-06 & 3.63 E-06 & 1.51 E-05 & 3.34 E-05 & 7.38 E-05 & 2.09 E-04 \\ 2.48 & 1.66 E-09 & 3.64 E-07 & 1.14 E-06 & 4.75 E-06 & 1.05 E-05 & 2.45 E-05 & 6.58 E-05 \\ 4.49 & 9.18 E-09 & 2.01 E-07 & 6.30 E-07 & 2.62 E-06 & 5.81 E-06 & 1.35 E-05 & 3.63 E-05 \\ 6.95 & 5.93 E-09 & 1.30 E-07 & 4.07 E-07 & 1.70 E-06 & 3.75 E-06 & 8.73 E-06 & 2.35 E-05 \\ 9.63 & 4.28 E-09 & 9.36 E-08 & 2.94 E-07 & 1.22 E-06 & 2.71 E-06 & 6.30 E-06 & 1.69 E-05 \\ 12.54 & 3.29 E-09 & 7.19 E-08 & 2.26 E-07 & 9.40 E-07 & 2.08 E-06 & 4.84 E-06 & 1.30 E-05 \\ 15.67 & 2.63 E-09 & 5.75 E-08 & 1.91 E-07 & 7.52 E-07 & 1.66 E-06 & 3.87 E-06 & 1.04 E-05 \\ 17.88 & 2.31 E-09 & 5.04 E-08 & 1.58 E-07 & 6.59 E-07 & 1.46 E-06 & 3.39 E-06 & 9.12 E-06\end{array}$


GROUND LEVEL RELEASE

XOQ FOF: A DISTANCE OF $7200 \quad M$

\begin{tabular}{cccccccc} 
SPEED & 1 & 2 & 3 & \multicolumn{5}{c}{ STABILITY } & 5 & 6 & 7 \\
0.78 & $3.66 E-08$ & $5.14 E-07$ & $1.74 E-06$ & $8.27 E-06$ & $1.91 E-05$ & $4.56 E-05$ & $1.22 E-04$ \\
2.48 & $1.15 E-08$ & $1.62 E-07$ & $5.47 E-07$ & $2.60 E-06$ & $6.01 E-06$ & $1.43 E-05$ & $3.83 E-05$ \\
4.19 & $6.37 E-09$ & $8.93 E-08$ & $3.02 E-07$ & $1.44 E-06$ & $3.32 E-06$ & $7.93 E-06$ & $2.11 E-05$ \\
6.95 & $4.11 E-09$ & $5.77 E-08$ & $1.95 E-07$ & $9.28 E-07$ & $2.15 E-06$ & $5.12 E-06$ & $1.37 E-05$ \\
9.63 & $2.97 E-09$ & $4.16 E-08$ & $1.41 E-07$ & $6.69 E-07$ & $1.55 E-06$ & $3.70 E-06$ & $9.86 E-06$ \\
12.54 & $2.28 E-09$ & $3.20 E-08$ & $1.08 E-07$ & $5.14 E-07$ & $1.19 E-06$ & $2.84 E-06$ & $7.57 E-06$ \\
15.67 & $1.82 E-09$ & $2.56 E-08$ & $8.65 E-08$ & $4.11 E-07$ & $9.51 E-07$ & $2.27 E-06$ & $6.06 E-06$ \\
17.88 & $1.60 E-09$ & $2.24 E-08$ & $7.58 E-08$ & $3.61 E-07$ & $8.34 E-07$ & $1.99 E-06$ & $5.31 E-06$
\end{tabular}


FROTIRAM TO COMFUTE XOO TOR ALL STAEILITIES AND WIND SFEED

CLASSES AT HANFOFID FOF SELECTED DISTANCES. . . NFIC DIFFUSION COEFFICIENTS AFE USED, AS IS A GAUSSIAN, ELEVATED RELEAGE. CENTER LINE MODEL.

FELEASE HEIGHT IS 80 METEFS

\section{SIGMA Y}

$\begin{array}{rccccccc}\text { DIST. } & 1 & 2 & 3 & 1 & 5 & 6 & 7 \\ 100 & 23.4 & 17.6 & 13.4 & 9.4 & 6.7 & 4.6 & 3.1 \\ 335 & 69.8 & 52.5 & 39.8 & 28.1 & 19.9 & 13.8 & 9.2 \\ 500 & 100.2 & 75.3 & 57.2 & 40.3 & 28.6 & 19.8 & 13.2 \\ 800 & 153.1 & 115.2 & 87.4 & 61.6 & 43.8 & 30.2 & 20.1 \\ 2400 & 413.0 & 310.6 & 235.8 & 166.1 & 118.1 & 81.5 & 54.3 \\ 4800 & 772.3 & 580.8 & 441.0 & 310.6 & 220.8 & 152.4 & 101.5 \\ 7200 & 1113.8 & 837.6 & 636.1 & 447.9 & 318.5 & 219.8 & 146.5\end{array}$

SIGMA 2

$\begin{array}{rrrrrrrr}100 & 14.3 & 10.9 & 7.5 & 4.6 & 3.5 & 2.2 & 1.4 \\ 335 & 61.8 & 33.7 & 22.6 & 13.3 & 9.6 & 6.0 & 3.6 \\ 500 & 123.6 & 51.5 & 32.5 & 18.4 & 13.0 & 8.2 & 5.0 \\ 800 & 294.0 & 86.0 & 49.9 & 26.6 & 18.3 & 11.7 & 7.1 \\ 2400 & 2863.7 & 285.0 & 135.7 & 56.9 & 38.3 & 24.7 & 13.5 \\ 4800 & 9999.9 & 607.9 & 255.1 & 87.0 & 55.3 & 34.4 & 19.2 \\ 7200 & 99999.9 & 947.6 & 369.1 & 110.2 & 67.0 & 40.7 & 22.9\end{array}$




\section{ELEVATED RELEASE}

XOQ FOFI A DISTANUE OF $100 \mathrm{M}$

$\begin{array}{cccccccc}\text { SPEED } & 1 & 2 & 3 & \text { STABILITY } & 5 & 6 & 7 \\ 0.78 & 1.95 E-10 & 4.01 E-15 & 8.03 E-28 & 0.00 E+00 & 0.00 E+00 & 0.00 E+00 & 0.00 E+00 \\ 2.48 & 6.13 E-11 & 1.26 E-15 & 2.53 E-28 & 0.00 E+00 & 0.00 E+00 & 0.00 E+00 & 0.00 E+00 \\ 1.49 & 3.38 E-11 & 6.96 E-16 & 1.40 E-28 & 0.00 E+00 & 0.00 E+00 & 0.00 E+00 & 0.00 E+00 \\ 6.95 & 2.19 E-11 & 1.50 E-16 & 9.02 E-29 & 0.00 E+00 & 0.00 E+00 & 0.00 E+00 & 0.00 E+00 \\ 9.63 & 1.58 E-11 & 3.25 E-16 & 6.51 E-29 & 0.00 E+00 & 0.00 E+00 & 0.00 E+00 & 0.00 E+00 \\ 12.54 & 1.21 E-11 & 2.49 E-16 & 5.00 E-29 & 0.00 E+00 & 0.00 E+00 & 0.00 E+00 & 0.00 E+00 \\ 15.67 & 9.70 E-12 & 1.99 E-16 & 4.00 E-29 & 0.00 E+00 & 0.00 E+00 & 0.00 E+00 & 0.00 E+00 \\ 17.88 & 8.50 E-12 & 1.75 E-16 & 3.51 E-29 & 0.00 E+00 & 0.00 E+00 & 0.00 E+00 & 0.00 E+00\end{array}$

XOQ FOFI A DISTANCE OF ISE M

$\begin{array}{rccccccc}\text { SPEED } & 1 & 2 & 3 & \text { STABILITY } & 4 & 6 & 7 \\ 0.79 & 1.10 E-05 & 1.39 E-05 & 8.46 E-07 & 1.65 E-11 & 1.44 E-18 & 0.00 E+00 & 0.00 E+00 \\ 2.48 & 1.29 E-05 & 4.36 E-06 & 2.66 E-07 & 5.20 E-12 & 4.53 E-19 & 0.00 E+00 & 0.00 E+00 \\ 4.49 & 7.12 E-06 & 2.41 E-06 & 1.47 E-07 & 2.87 E-12 & 2.50 E-19 & 0.00 E+00 & 0.00 E+00 \\ 6.95 & 4.60 E-06 & 1.55 E-06 & 9.49 E-09 & 1.86 E-12 & 1.62 E-19 & 0.00 E+00 & 0.00 E+00 \\ 9.63 & 3.32 E-06 & 1.12 E-06 & 6.85 E-08 & 1.34 E-12 & 1.17 E-19 & 0.00 E+00 & 0.00 E+00 \\ 12.54 & 2.55 E-06 & 8.62 E-07 & 5.26 E-08 & 1.03 E-12 & 8.95 E-20 & 0.00 E+00 & 0.00 E+00 \\ 15.67 & 2.04 E-06 & 6.90 E-07 & 4.21 E-08 & 8.24 E-13 & 7.16 E-20 & 0.00 E+00 & 0.00 E+00 \\ 17.28 & 1.79 E-06 & 6.04 E-07 & 3.69 E-08 & 7.22 E-13 & 6.28 E-20 & 0.00 E+00 & 0.00 E+00\end{array}$


ELEVATED RELEASE

XOQ FOF: A DISTANCE OF $500 \mathrm{M}$

\begin{tabular}{rccccccc} 
SPEED & 1 & 2 & 3 & \multicolumn{5}{c}{ STABILITY } & 5 & 6 & 7 \\
0.78 & $2.67 E-05$ & $3.15 E-05$ & $1.06 E-05$ & $1.31 E-08$ & $5.88 E-12$ & $5.13 E-24$ & $0.00 E+00$ \\
2.48 & $8.41 E-06$ & $9.90 E-06$ & $3.34 E-06$ & $1.35 E-08$ & $1.85 E-12$ & $1.61 E-24$ & $0.00 E+00$ \\
4.49 & $4.64 E-06$ & $5.47 E-06$ & $1.84 E-06$ & $7.48 E-09$ & $1.02 E-12$ & $8.91 E-25$ & $0.00 E+00$ \\
6.95 & $3.00 E-06$ & $3.53 E-06$ & $1.19 E-06$ & $4.83 E-09$ & $6.60 E-13$ & $5.76 E-25$ & $0.00 E+00$ \\
9.63 & $2.17 E-06$ & $2.55 E-06$ & $8.59 E-07$ & $3.49 E-09$ & $4.77 E-13$ & $4.15 E-25$ & $0.00 E+00$ \\
12.54 & $1.66 E-06$ & $1.96 E-06$ & $6.60 E-07$ & $2.68 E-09$ & $3.66 E-13$ & $3.19 E-25$ & $0.00 E+00$ \\
15.67 & $1.33 E-06$ & $1.57 E-06$ & $5.28 E-07$ & $2.14 E-09$ & $2.93 E-13$ & $2.55 E-25$ & $0.00 E+00$ \\
17.88 & $1.17 E-06$ & $1.37 E-06$ & $4.63 E-07$ & $1.88 E-09$ & $2.57 E-13$ & $2.24 E-25$ & $0.00 E+00$
\end{tabular}

XOQ FOF A DISTANCE OF $600 \mathrm{M}$

$\begin{array}{rccccccc}\text { SPEED } & 1 & 2 & 3 & 4 \text { STABILITY } & 5 & 6 & 7 \\ 0.78 & 8.74 E-06 & 2.67 E-05 & 2.58 E-05 & 2.67 E-06 & 3.66 E-08 & 9.87 E-14 & 8.61 E-31 \\ 2.48 & 2.75 E-06 & 8.41 E-06 & 8.13 E-06 & 8.40 E-07 & 1.15 E-08 & 3.10 E-14 & 2.71 E-31 \\ 4.49 & 1.52 E-06 & 1.64 E-06 & 1.49 E-06 & 4.64 E-07 & 6.36 E-09 & 1.71 E-14 & 1.50 E-31 \\ 6.95 & 9.80 E-07 & 3.00 E-06 & 2.90 E-06 & 3.00 E-07 & 4.11 E-09 & 1.11 E-14 & 9.66 E-32 \\ 9.63 & 7.08 E-07 & 2.17 E-06 & 2.09 E-06 & 2.16 E-07 & 2.96 E-09 & 7.99 E-15 & 6.97 E-32 \\ 12.54 & 5.43 E-07 & 1.66 E-06 & 1.61 E-06 & 1.66 E-07 & 2.28 E-09 & 6.14 E-15 & 5.36 E-32 \\ 15.67 & 4.35 E-07 & 1.33 E-06 & 1.29 E-06 & 1.33 E-07 & 1.82 E-09 & 4.91 E-15 & 4.29 E-32 \\ 17.88 & 3.81 E-07 & 1.17 E-06 & 1.13 E-06 & 1.16 E-07 & 1.60 E-09 & 4.31 E-15 & 3.76 E-32\end{array}$


ELEVATED RELEASE

$x$ PO FOF A DISTANCE OF $2400 \mathrm{~m}$

$\begin{array}{cccccccc}\text { SFEED } & 1 & 2 & 3 & 4 \text { STABILITY } & 5 & 6 & 7 \\ 0.78 & 3.45 E-07 & 4.43 E-06 & 1.07 E-05 & 1.61 E-05 & 1.02 E-05 & 1.06 E-06 & 1.47 E-11 \\ 2.48 & 1.08 E-07 & 1.39 E-06 & 3.37 E-06 & 5.06 E-06 & 3.20 E-06 & 3.32 E-07 & 4.62 E-12 \\ 4.49 & 5.99 E-08 & 7.70 E-07 & 1.86 E-06 & 2.79 E-06 & 1.77 E-06 & 1.83 E-07 & 2.55 E-12 \\ 6.95 & 3.87 E-08 & 4.97 E-07 & 1.20 E-06 & 1.90 E-06 & 1.14 E-06 & 1.18 E-07 & 1.65 E-12 \\ 9.63 & 2.79 E-08 & 3.59 E-07 & 8.68 E-07 & 1.30 E-06 & 8.23 E-07 & 8.55 E-06 & 1.17 E-12 \\ 12.54 & 2.15 E-08 & 2.76 E-07 & 6.67 E-07 & 1.00 E-06 & 6.32 E-07 & 6.57 E-08 & 9.14 E-13 \\ 15.67 & 1.72 E-08 & 2.21 E-07 & 5.34 E-07 & 8.00 E-07 & 5.05 E-07 & 5.26 E-08 & 7.32 E-13 \\ 17.88 & 1.50 E-08 & 1.93 E-07 & 4.68 E-07 & 7.01 E-07 & 4.43 E-07 & 4.61 E-08 & 6.411 E-13\end{array}$

XOQ FOF A DISTANCE OF $4000 \mathrm{M}$

$\begin{array}{rccccccc}\text { SPEED } & 1 & 2 & 3 & 4 & 5 & 6 & 7 \\ 0.78 & 5.28 E-08 & 1.15 E-06 & 3.45 E-06 & 9.90 E-06 & 1.17 E-05 & 5.21 E-06 & 3.63 E-08 \\ 2.48 & 1.66 E-08 & 3.60 E-07 & 1.09 E-06 & 3.11 E-06 & 3.69 E-06 & 1.64 E-06 & 1.14 E-08 \\ 4.49 & 9.18 E-09 & 1.99 E-07 & 6.00 E-07 & 1.72 E-06 & 2.04 E-06 & 9.05 E-07 & 5.30 E-09 \\ 6.95 & 5.93 E-09 & 1.29 E-07 & 3.83 E-07 & 1.11 E-06 & 1.32 E-06 & 5.85 E-07 & 4.07 E-09 \\ 9.63 & 4.28 E-09 & 9.28 E-08 & 2.80 E-07 & 8.02 E-07 & 9.50 E-07 & 4.22 E-07 & 2.94 E-09 \\ 12.54 & 3.29 E-09 & 7.13 E-08 & 2.15 E-07 & 6.16 E-07 & 7.30 E-07 & 3.24 E-07 & 2.26 E-09 \\ 15.67 & 2.63 E-09 & 5.70 E-08 & 1.72 E-07 & 4.93 E-07 & 5.84 E-07 & 2.59 E-07 & 1.80 E-09 \\ 17.88 & 2.31 E-09 & 5.00 E-08 & 1.51 E-07 & 4.32 E-07 & 5.12 E-07 & 2.27 E-07 & 1.505-09\end{array}$


$\lambda$ DOO FOF A DISTANCE OF $7200 \mathrm{M}$

\begin{tabular}{cccccccc} 
SPEED & 1 & 2 & 3 & \multicolumn{5}{c}{ STABILITY } & 5 & 6 & 7 \\
0.78 & $3.66 E-08$ & $5.12 E-07$ & $1.70 E-06$ & $6.35 E-06$ & $9.38 E-06$ & $6.60 E-06$ & $2.71 E-07$ \\
2.48 & $1.15 E-09$ & $1.61 E-07$ & $5.34 E-07$ & $2.00 E-06$ & $2.95 E-06$ & $2.08 E-06$ & $8.52 E-08$ \\
4.49 & $6.36 E-09$ & $8.90 E-08$ & $2.95 E-07$ & $1.10 E-06$ & $1.63 E-06$ & $1.15 E-06$ & $4.71 E-08$ \\
6.95 & $4.11 E-09$ & $5.75 E-08$ & $1.91 E-07$ & $7.13 E-07$ & $1.05 E-06$ & $7.41 E-07$ & $3.04 E-08$ \\
9.63 & $2.97 E-09$ & $4.15 E-08$ & $1.38 E-07$ & $5.14 E-07$ & $7.60 E-07$ & $5.35 E-07$ & $2.19 E-08$ \\
12.51 & $2.28 E-09$ & $3.19 E-08$ & $1.06 E-07$ & $3.95 E-07$ & $5.83 E-07$ & $4.11 E-07$ & $1.69 E-08$ \\
15.67 & $1.82 E-09$ & $2.55 E-08$ & $8.45 E-08$ & $3.16 E-07$ & $4.67 E-07$ & $3.29 E-07$ & $1.35 E-08$ \\
17.88 & $1.60 E-09$ & $2.23 E-08$ & $7.41 E-08$ & $2.77 E-07$ & $4.09 E-07$ & $2.88 E-07$ & $1.18 E-08$
\end{tabular}




\section{C.8.2 Reference C.7 from Section C.7}

From. Radiation and Shield Analys is

Phone: 6-4023 D-1

Date: February 20, 1986

Westinghouse Hanford Company

Subject: FISSION PRODUCTS IN SP-100

RSA :Mf 86-006
ast
To: W. L. Bunch $D-1$
CC: RA Bennett, D-3 PAB WC Miller, C-27
TM Burke, F-16 AR Schade, A-52
LL Carter, D-1 JB Waldo, F-35
CM Cox, $\mathrm{C}-27 \quad A B$ Webb, $A-52$
JE Irvin, $\mathrm{C}-27$
MK Mahaffey, C-27
JC Wiborg, A-52
SP-100 Test Site File, $C-27$
RJM:File/LB
Reference: Memo, JC Wiborg to WL Bunch et al., "SP-100 Safety Issue Identification; Meeting," dated February 11, 1986.

The referenced memo indicates that there is a need for fission product information to assess potential safety problems associated with the ground test of a space reactor system. To provide realistic preliminary information that is expected to be useful for scoping safety concerns, I have made a RIBD calculation assuming two years of continuous operation at a power level of $8 \mathrm{MW}$. Because the exact characteristics of the reactor are not known, it was assumed that $99 \%$ of the fission events would be associated with the fast-neatron induced fission of $235 \mathrm{~J}$ and the other one percent with $238 \mathrm{U}$. The neutron ilux level was assumed to be $10^{15} \mathrm{n} / \mathrm{cm}^{2} \mathrm{sec}$, with $200 \mathrm{MeV}$ being relcased per fission event. These assumptions are all believed to be realistic and are not expected to introduce significant bias or error into the results.

Table 1 presents the curie inventory of the fission product elcinents as a function of decay time, whereas Table 2 presents the energy (heating) associated with various groupings of fission products. A complete listing of fission product inventories, curies, and decay heat rates by isotope is being forwarded to Safety ( $J$ Wiborg) with this memo for his use. It should be recognized that structural materials, coolant, control materials, and reflector components are not included in this calculation. These can be calculated when a more exact model of the actual reactor becomes available. The fission product inventory will probably be more dependent on actual operating history than in the uncertainty of the present assumptions.

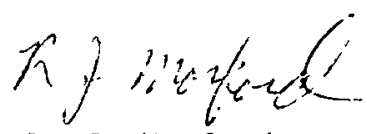

R. J. Morford

$\operatorname{lir}$

Attachments: Tables $1 \& 2$ 
TABLE 1. FISSION PRODUCT INVENTORY BY ELEMENT

SP-100, 3 MW FOR 2 YEARS, U-235 FAS ACTIVITY AFTER SHUTDOWN - CURIES

5840.0 MWD IN 730.0 DAYS.

SUMMARY

\begin{tabular}{|c|c|c|}
\hline 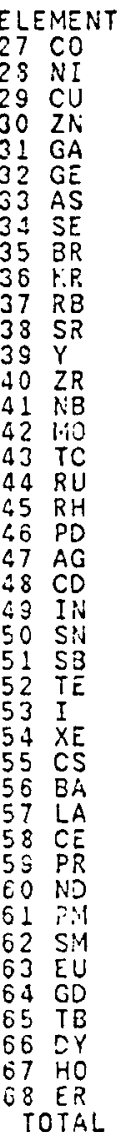 & $\begin{array}{l}\text { SHUTDOWN } \\
3.038-001 \\
2.419+001 \\
3.544+002 \\
3.800+003 \\
1.435+004 \\
5.818+004 \\
1.486+005 \\
3.978+005 \\
8.125+005 \\
1.401+006 \\
2.021+006 \\
2.727+006 \\
3.672+006 \\
2.409+006 \\
3.320+006 \\
1.556+006 \\
1.552+006 \\
3.911+005 \\
4.340+005 \\
2.536+004 \\
3.610+004 \\
2.798+004 \\
7.151+004 \\
3.030+005 \\
8.670+005 \\
1.336+006 \\
2.683+006 \\
2.429+006 \\
1.922+006 \\
2.468+006 \\
2.434+006 \\
1.351+006 \\
1.537+006 \\
2.776+005 \\
2.040+005 \\
1.973+004 \\
5.309+003 \\
2.587+002 \\
5.149+001 \\
2.737-001 \\
2.350-002 \\
.000 \\
3.937+007\end{array}$ & $\begin{array}{l}1.00 \text { DAYS } \\
.000 \\
.000 \\
.000 \\
9.435+000 \\
1.307+001 \\
1.862+002 \\
1.550+003 \\
1.404-001 \\
2.212+002 \\
5.332+003 \\
1.647+003 \\
3.841+005 \\
5.322+005 \\
5.735+005 \\
7.343+005 \\
3.044+005 \\
2.912+005 \\
2.529+005 \\
3.113+005 \\
3.529+003 \\
6.570+003 \\
1.552+003 \\
1.686+003 \\
5.124+003 \\
1.921+004 \\
3.214+005 \\
7.014+005 \\
6.220+005 \\
2.486+004 \\
4.081+005 \\
4.143+005 \\
9.223+005 \\
6.940+005 \\
1.343+005 \\
1.323+005 \\
9.488+003 \\
3.069+003 \\
9.436+001 \\
4.301+001 \\
6.075-003 \\
1.580-002 \\
.000\end{array}$ \\
\hline
\end{tabular}

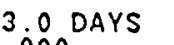

.000

.000

4. $616+000$

$6.455+000$
$9.726+000$

$438+002$
$404-001$

$1.404-001$
$.401+00$

$2.305+003$
$809+002$

$3.409+002$
$3.111+005$

$3.322+005$

$4.358+005$

$1.838+005$

$1.772+005$

2. $430+005$

2. $665+005$

$423+002$
$2.767+003$

$2.767+003$
$335+002$

$8.957+002$

$3.776+003$

$1.319+004$

$3.804+005$

$3.790+005$

$2.457+004$
$3.680+005$

$3.051+005$

$7.562+C 05$
$6.530+005$

1. $165+005$

$9.165+005$

$4.750 \div 003$

$1.671+001$
$1.571+0.19$

$3.943-003$

.800

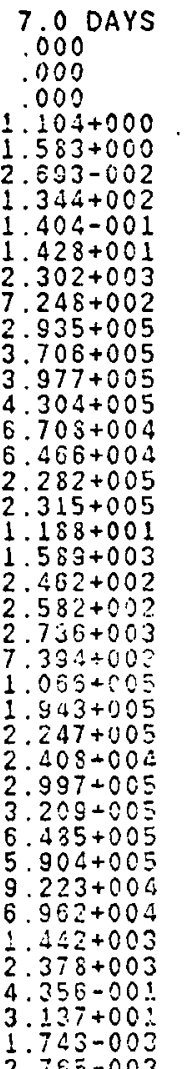

$\frac{1}{2} .785-003$

.0000000
4.0 DAYS 30.00 DAYS

.000
.000

.000

$9.028-002$

$1.296-001$
$9.006-007$

$6.681+000$

$\frac{1}{5} .404-001$

$2.299+003$

$5.588+002$

$3.424+005$

$3.683+005$

1. $1.49+004$

$\frac{1}{2} .108+004$

$2.045+005$

$4.723-002$

$8.243+002$

$3 \cdot 5 \cdot 5+001$

$\frac{1}{3} .572+00$

$4.473-004$

$8.233+\mathrm{OC}$

$8.343+004$
$2.343+004$

$2.217+005$

$5.844+005$

$4.989+005$

$6.067+004$

$4.824+002$

$8.207-004$

2. $373+00$

6. $244-004$

$3.720+006$
.000

$2.954-004$

4. $239-004$

$5.300-017$

$7.016-003$
$1.404-001$

$2.805-004$
$2.293+003$

$3.084+002$

$2.185+005$

$3.098+005$

$4.006+005$

$1.988+002$

$1.604+005$

$4.774-003$

$\frac{1}{7} .909+002$

$2.009-001$

$8.751+002$

$2.152+004$

$1.719+004$

$\frac{1}{2} \cdot 258+004$

$9.870+004$
$9.324+004$

$4.866+005$

3. $693+005$

$2.182+004$

$3.561+002$

$1.483+003$

1. $621+001$

1. $594-005$

2.00000
0 DAYS 180.0 DAYS .000

$.464-003 \quad 1.483-027$

2 - $0092.128-02$

$.825-008 \quad 8.347-031$

$.404-0011.404-00$

$2.035-010$

$281+002$

.000

$2.233+003$
$1.173+000$

$4.254+004$

$240+005 \quad 6.119+004$

$.385+005$

$.059-001$

$.592+000$

$1.043+005$
$1.042+005$

$4.774-003$

$1.720+001$

$1.770-005$

1. $823+003$

i. $290+004$

$\frac{1}{3} \cdot 255+003$

$2.138+004$

$3.352+004$

$1.835+004$

$2.775+005$

$3.329+003$

$5.65+004$

1. $117+003$

1. $127+001$

3. $493-003$

$9.219-008$

1. $\$ 25+006$

$1.211+005$
$7.749-015$

$2.490+000$

$3.014+004$

$4.774-003$

$4.217+000$

$4.536+000$
$5.346-012$

$2.654+002$

$2.975+003$

4.558-002

$2.040-001$

$2.138+004$

$2.749+001$

$1.955+005$
$1.923+005$

1. $923+005$
1. $804+000$

$.035+004$

$360+005$

$.534+002 \quad 8.930+002 \quad 3.811+002$

$3.549+000 \quad 6.023-001 \quad 5.023-007$

$\begin{array}{lll}8.058-019 & 3.217-035 & .000 \\ 4.013-008 & 4.012-008 & 4.003-008\end{array}$

.000 .

$4.279+005 \quad 9.045+004$ 
TABLE 2. FISSION PRODUCT DECAY HEAT

\begin{tabular}{|c|c|c|c|c|c|c|c|c|c|c|}
\hline$S P-100,8$ & $M W$ FOR 2 & RSS, U-235 & $\begin{array}{l}\text { FAS } \\
\text { TOTAL }\end{array}$ & POW & SHUTDOWN - & Mw & $340.0 \mathrm{MND}$ & $730.0 \mathrm{D}$ & AYS & MMARY \\
\hline ELEMENT & SHUTDOWN & 1.0 DAYS & 3.0 DAYS & 7.0 DAYS & 14.0 DAYS & 30.0 DAYS & 60.0 DAYS & 180.0 DAYS & 1.0 YRS. & 5.0 YRS. \\
\hline NOBLE GAS & $4.220-002$ & $1.074-003$ & $4.286-004$ & $2.467-004$ & $1.005-004$ & $1.579-005$ & $3.822-006$ & $3.346-006$ & $3.238-006$ & $2.500-000$ \\
\hline HALOGENS & $6.029-002$ & $6.593-003$ & $3.602-003$ & $1.602-003$ & $4.908-004$ & $6.536-005$ & $4.270-006$ & $1.391-010$ & $2.369-012$ & $2.369-012$ \\
\hline VOL. SOL. & $1.517-001$ & $6.705-003$ & $3.694-003$ & $1.685-003$ & $5.652-004$ & $1.288-004$ & $6.038-005$ & $5.061-005$ & $4.563-005$ & $2.501-005$ \\
\hline A.R.F.P. & $3.072-001$ & $2.766-002$ & $2.159-002$ & $1.818-002$ & $1.491-002$ & $1.075-002$ & $7.276-003$ & $3.118-003$ & $1.466-003$ & $2.082-004$ \\
\hline & 00. & $3.544-002$ & $.572-002$ & $011-002$ & $.558-002$ & 102 & $.340=005$ & $3.172-003$ & $.515-003$ & $.357-004$ \\
\hline
\end{tabular}

NOTE: Vol. Sol. includes halogens plus $\mathrm{As}, \mathrm{Se}, \mathrm{Br}, \mathrm{Rb}, \mathrm{Cd}, \mathrm{I}$ and $\mathrm{Cs}$.

A.R.F.P. includes all other fission products (excludes noble gas \& Vol. Sol.). 


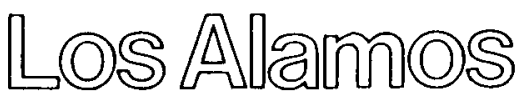

Los Alamos National Laboratory

Los Alamos, New Mexico 87545

$\begin{aligned} \text { DATE } & \text { March 28, 1986 } \\ \text { IN REPLY AEFER TO } & 0-6-86-488 \text { (B561) } \\ \text { MAIL STOP } & \text { K557 } \\ \text { TELEPHONE } & (505) 667-9402 \\ & \text { FTS 843-9402 }\end{aligned}$

Safety Asses sment

Mr. Carl M. Cox

Hanford Engineering Development Laboratory

P. 0. Box 1970

Richland, WA 99352

Dear Carl:

We have just completed a series of ORIGEN calculations based on a recent Los Alamos conceptual desigh for a 300-kWe SP-100 reactor.

Enclosed is a description of the assumptions used in the calculations. Some of the results also are given, namely, the production of ${ }^{3} \mathrm{H},{ }^{94} \mathrm{Nb}$, and $P u$ as a function of reactor operating time; the buildup of total activity; the decay heat at shutdown; and decay heat as a function of time after shutdown for three operating times. This information is being sent to you in response to Safety Items $1 a$ and 7 in our February 24, 1986 (Q-12-86-37), letter.

The calculations were performed for various reactor operating and decay times. The detailed results track the buildup and decay of isotopes for the structural material, the actinides, and the fission products both in grams and curies and their contribution to the decay heat. Summaries of the total activity and decay heat also were obtained. In addition, the gamma source strength was obtained as a function of energy both in photons/s and MeV/s, and the spontaneous fission rate is given. If any of this additional information would be useful to you, please let us know.

Currently, we are performing thermal analyses of the reactor based on this decay heat information. We will assess the system's ability to remove decay heat for both loss-of-flow and loss-of-coolant events. This information will be provided to you as soon as it is available. 
We also are performing a series of dose rate calculations based on the ORIGEN results. These calculations will account for a variety of reactor operating times, decay times, and shielding materials (soil, water, and tungsten). We would be glad to provide you with this information when it is complete if it would be useful to you.

If you have any questions regarding this information or if you need any additional details please call either me at the above number or Joan Boudreau at FTS 843-9105.

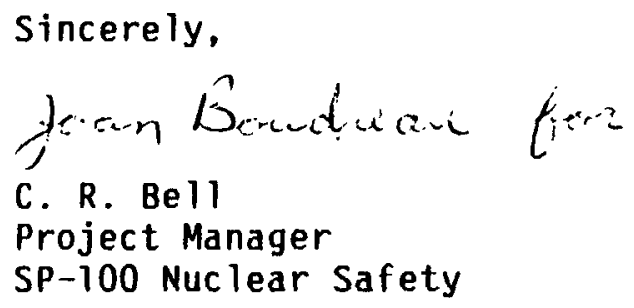

$\mathrm{CRB} / \mathrm{j} 1$

Enc. as cited

Cy: V. C. Truscello, JPL

A. R. Schade, HEDL

M. G. Stevenson/W. L. Kirk, Q-D0, MS E561

J. H. Scott, Q-DO/SMR, MS K560

J. E. Hanson, Q-00, MS K560

M. B. Parker, Q-12, MS K551

S. S. Voss, Q-12, MS K551

R. A. Haarman/W. S. Gregory, Q-6, MS K557

J. M. Boudreau, 0-6, MS K557

S. W. Eisenhawer, Q-6, MS $K 557$

C. Mc Inteer, Q-6, MS K557

CRM-4 (2), MS A150

Q-6 File 


\section{Assumptions}

The core design modeled in the ORIGEN calculations was based on a recent Los Alamos conceptual design for a 300-kWe (7.5-MWt) system. The characteristics of the reactor are summarized in Table 1. As shown in Fig. 1, the core has three enrichment zones $\left(51,75\right.$, and 97 per cent ${ }^{235} \mathrm{U}$ ). In the calculations, these regions were analyzed separately, and the results were summed.

For these calculations, only the active core was modeled (top of the core to the bottom plenum). The fission gas plenum, the upper portion of the reactor vessel, the shield, and so on were not included. Although this reduces the amount of niobium present, we belfeve it will not affect the total ${ }^{94} \mathrm{Nb}$ production significantly because ORIGEN subjects all the material within a region to the same flux. In actuality, the niobium in the reactor vessel would see a lower flux than the clad material. Therefore, the ${ }^{94} \mathrm{Nb}$ production in the vessel has been overestimated. This is compensated for by completely ignoring the niobium that is present above the active core. This material would see some flux and hence some ${ }^{94} \mathrm{Nb}$ would be produced, but it would be at a much slower rate than in the cladding or lower portion of the vessel.

The analysis included a lithium region around the core. This was eliminated recently by the Los Alamos design team. Therefore, the reactor model used in the calculations has more beryllium and almost twice as much lithium than our current conceptual design. Therefore, the ${ }^{3} \mathrm{H}$ production in the coolant is overestimated.

Table II shows how the material in the active core was allocated to each of the three regions. However, the code cannot treat tungsten and rhenium, and they actually were not included. The power level for each region was held constant over the entire time of operation, and the flux was varied by the code.

\section{Results}

ORIGEN calculations were performed for various reactor operating times ( 7 days to $7 \mathrm{yr}$ ) and decay times (86 s to $100000 \mathrm{yr}$ ). The production of tritium in the coolant is shown in Fig. 2 . It should be noted 
that this does not include the tritium produced as a fission product. The production of ${ }^{94} \mathrm{Nb}$ and $\mathrm{Pu}$ is linear as is shown in Figs. 3 and 4 , respectively. Figure 5 shows that the total activity saturates relatively quickly (reaching $90 \%$ of the maximum in 15 days). Total decay heat at shutdown is shown in Fig. 6. Figure 7 shows decay heat as a function of time after shutdown for reactor operating times of 7 days, 6 months, and 7 yr. 


\section{REACTOR CHARACTERISTICS}

Reactor Power, kW

Operating Time, yrs

Materials

Fuel

Clad/Structure

Coolant

Liner

Reflector/Followers

Control Rod Poison
7500

7

UN

PWC-11

$7_{\text {Li }}$

W-26\%Re

$\mathrm{BeO}$

$\mathrm{B}_{4} \mathrm{C}$

46.4

63.0

63.0

129.0

58.3

4.0

1770

.85

1.15

1400

55

1.3

357

$51,75,97$

1.4

13

18.6

4

13.4 


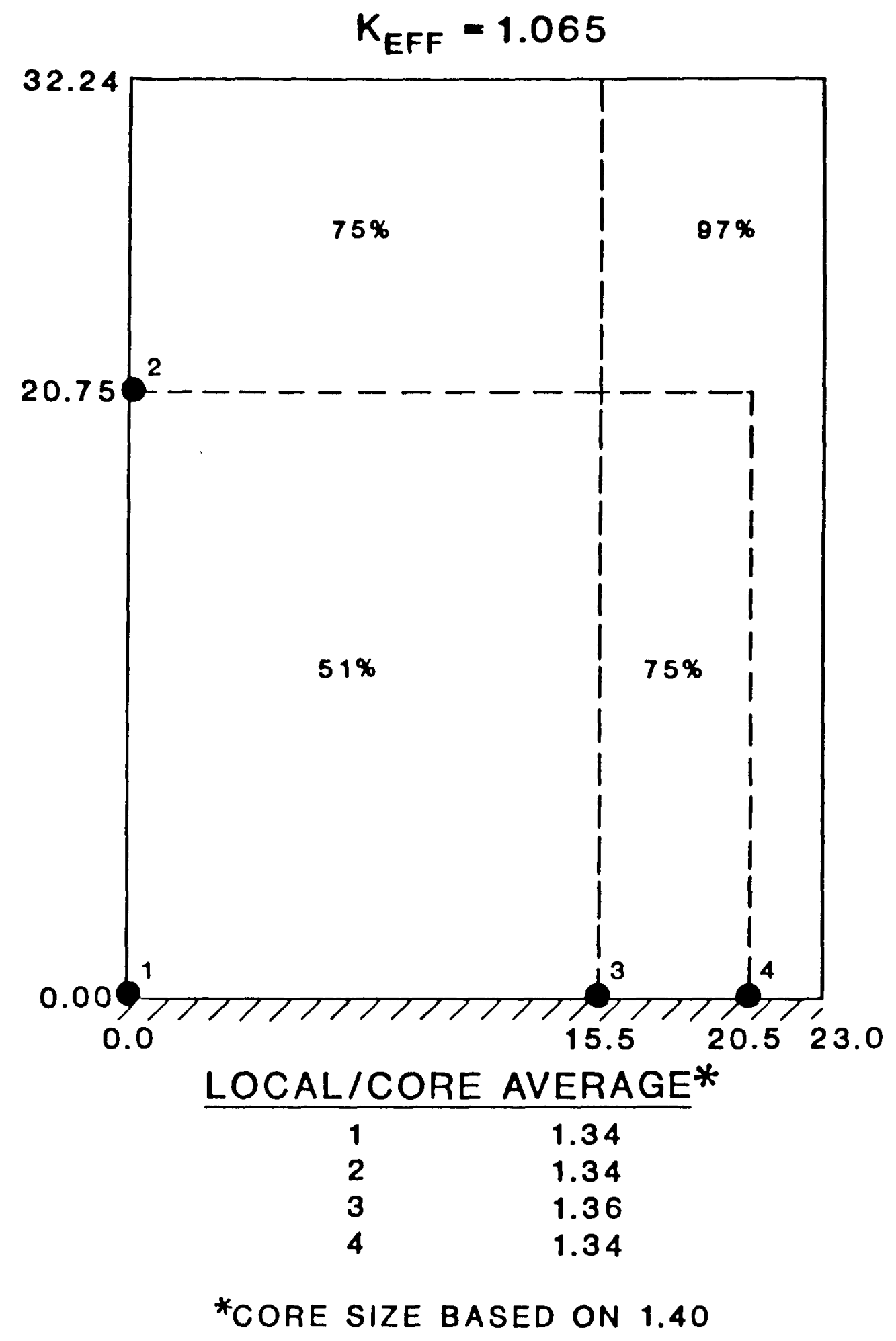

Fig. 1. Enrichment Zones for 300-kWe Reactor (Quarter Core). 
TABLE II

ORIGEN INPUT SUMMARY

\section{$\underline{\text { Region } 1} \quad \underline{\text { Region } 2} \quad \underline{\text { Region } 3} \quad \underline{\text { Total }}$}

\begin{tabular}{|c|c|c|c|c|}
\hline Power (MWt) & 2.28 & 2.86 & 2.36 & 7.50 \\
\hline Enrichment & $51 \%$ & $75 \%$ & $97 \%$ & \\
\hline Total U (kg) & 223.9 & 219.1 & 216.8 & 659.8 \\
\hline${ }^{235} \mathrm{U}(\mathrm{kg})$ & 113.5 & 163.8 & 210.2 & 487.5 \\
\hline${ }^{238} \mathrm{U}(\mathrm{kg})$ & 110.4 & 55.3 & 6.6 & 172.3 \\
\hline Lithium $(\mathrm{kg})^{a}$ & 0.2 & 9.0 & 10.5 & 19.8 \\
\hline Beryllium (kg) & 11.6 & 9.9 & 45.2 & 66.8 \\
\hline Boron (kg) & - & 9.3 & - & 9.3 \\
\hline Carbon (kg) & - & 1.3 & - & 1.3 \\
\hline Nitrogen (kg) & 13.3 & 13.0 & 12.9 & 39.2 \\
\hline Oxygen (kg) & 20.7 & 17.7 & 80.5 & 118.9 \\
\hline Niobium $(\mathrm{kg})$ & 77.2 & 187.9 & 93.0 & 358.1 \\
\hline Zirconium (kg) & 0.58 & 1.9 & 1.0 & 3.5 \\
\hline Tungsten (kg) & 29.5 & 28.9 & 28.6 & 87.0 \\
\hline
\end{tabular}

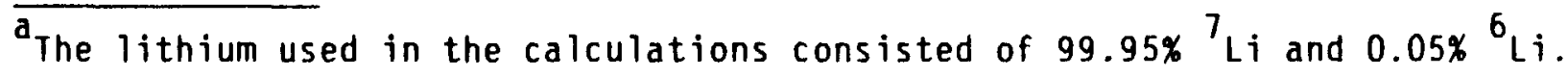




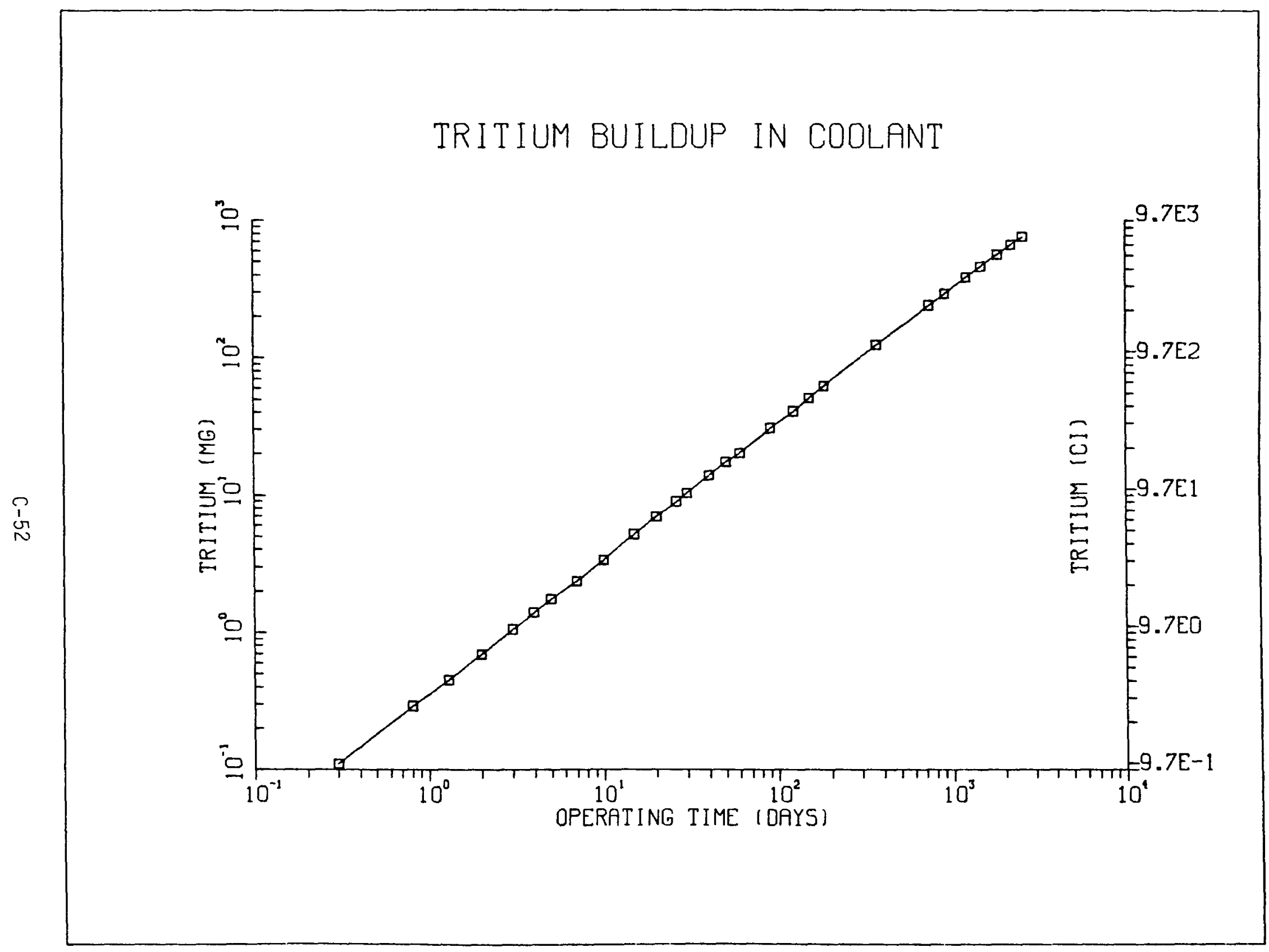

Fig. 2. Tritium buildup in the coolant. 


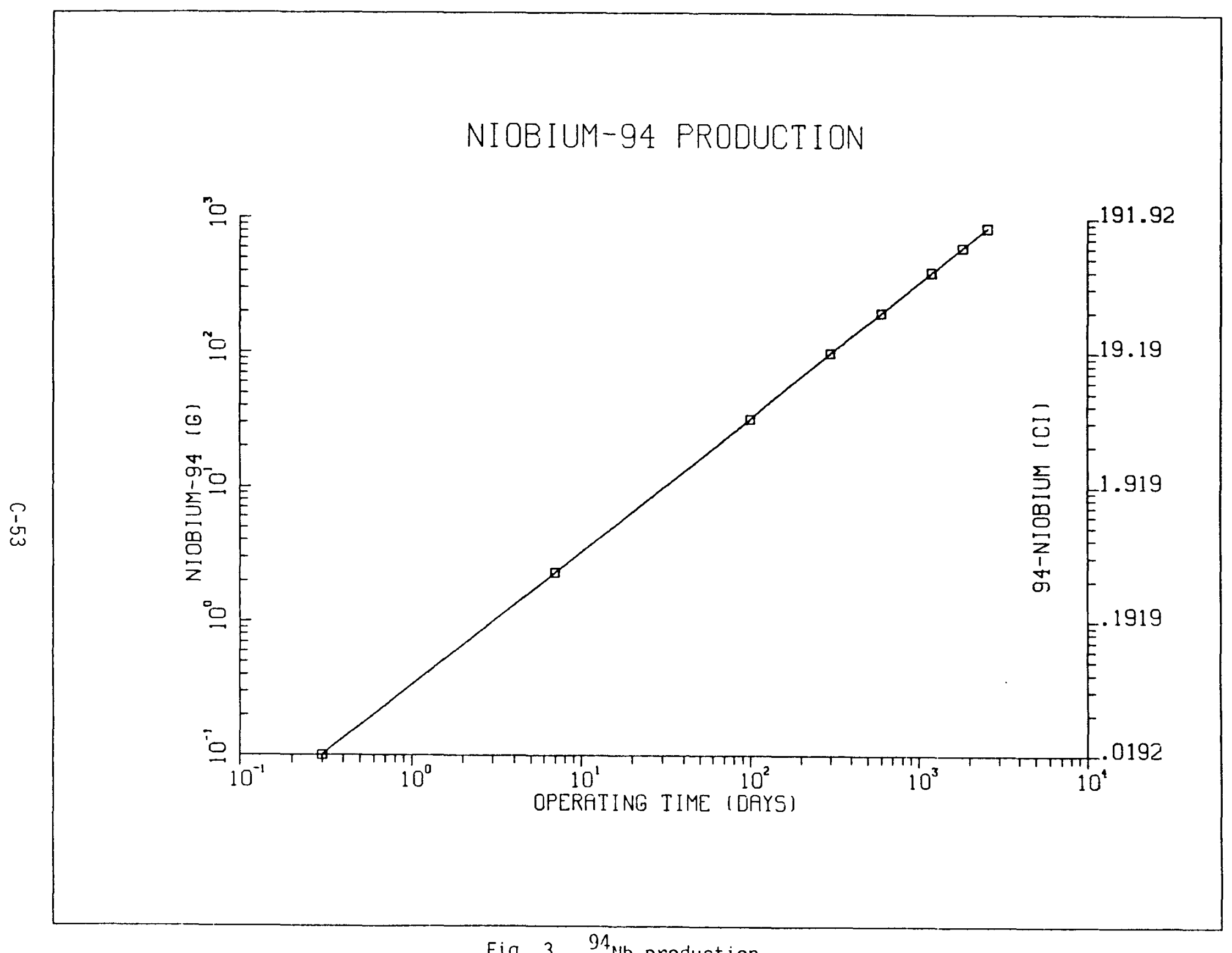

Fig. 3. $94_{\text {Nb }}$ production. 


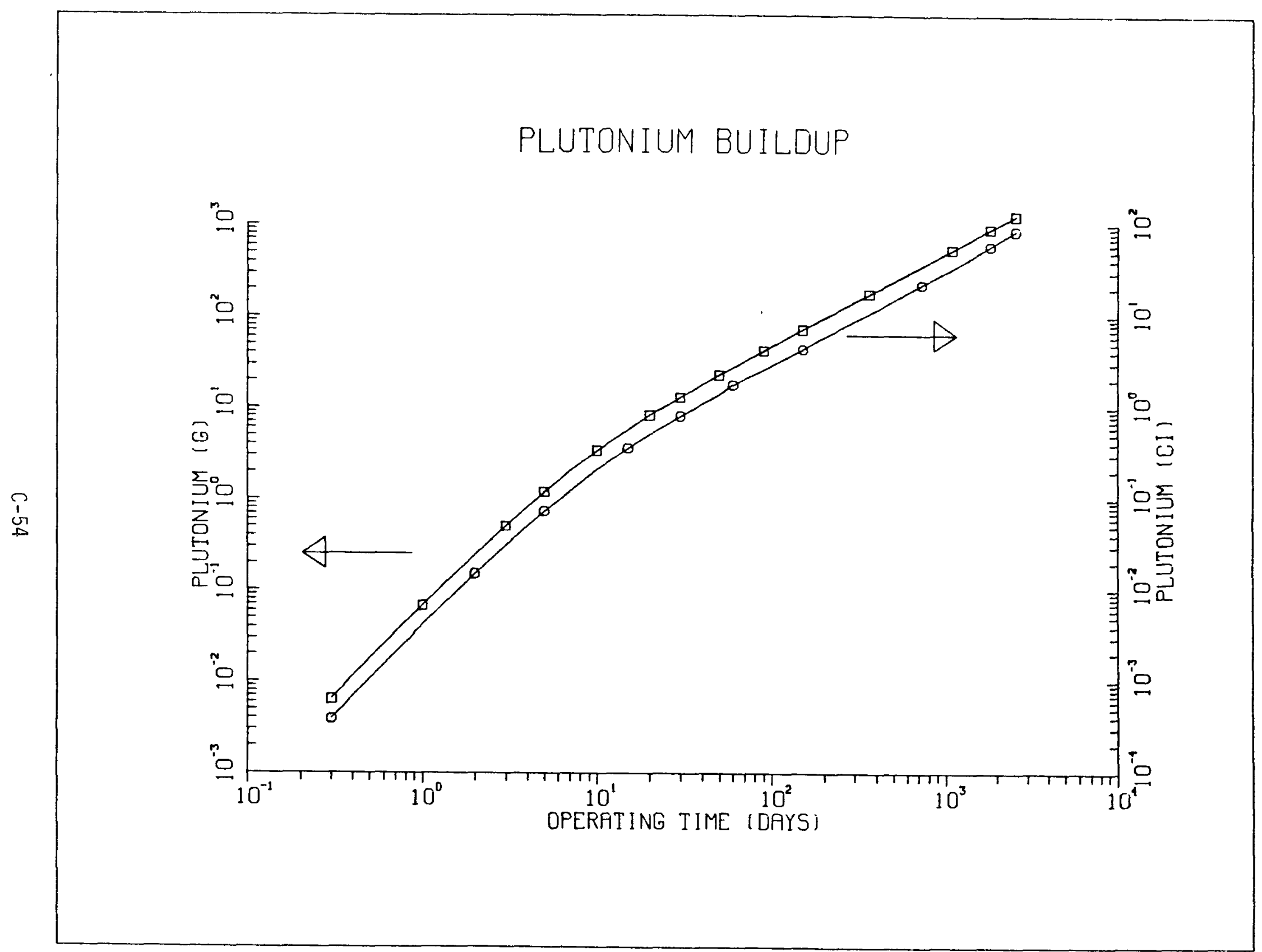

Fig. 4. Plutonium production. 


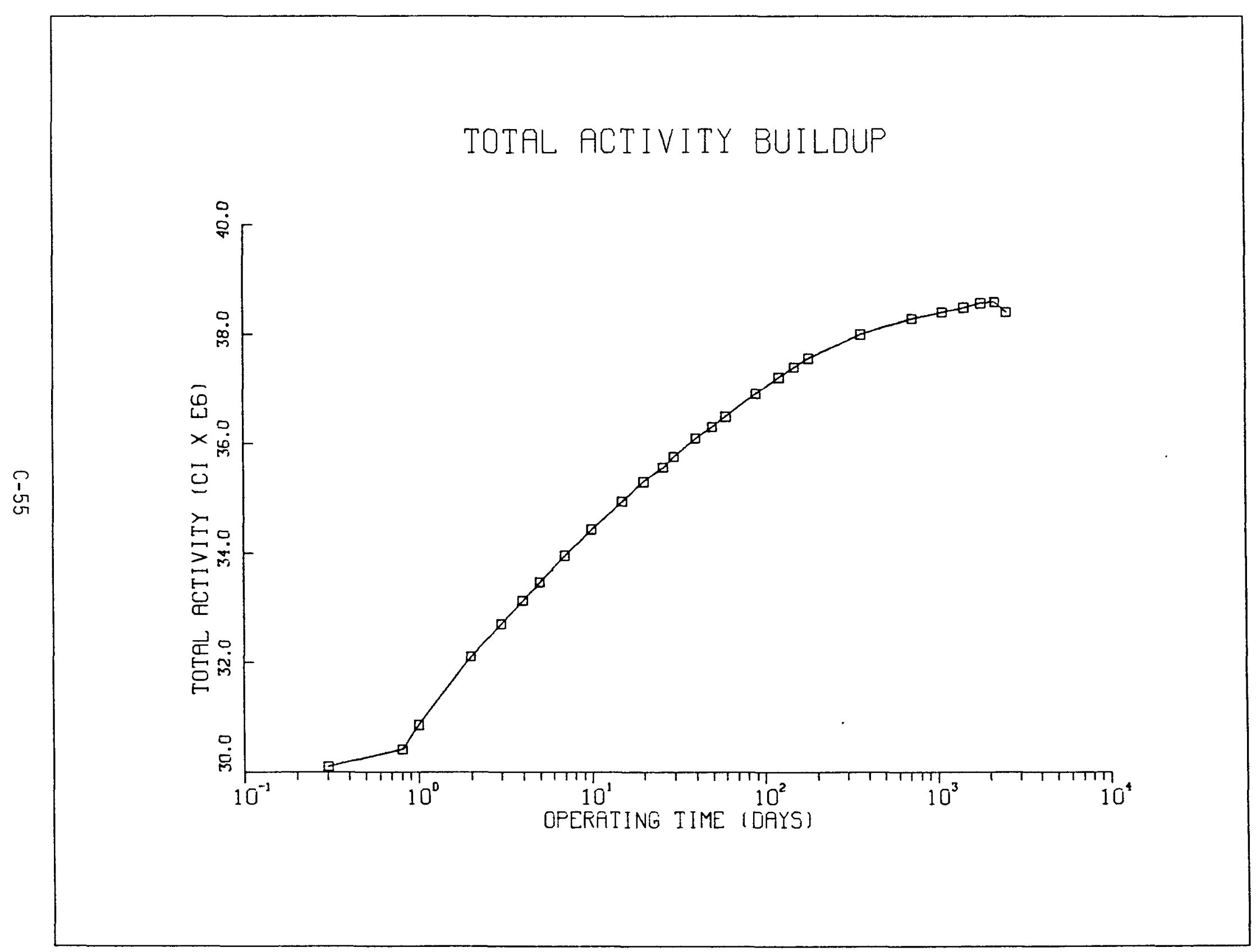

Fig. 5. Total activity buildup. 


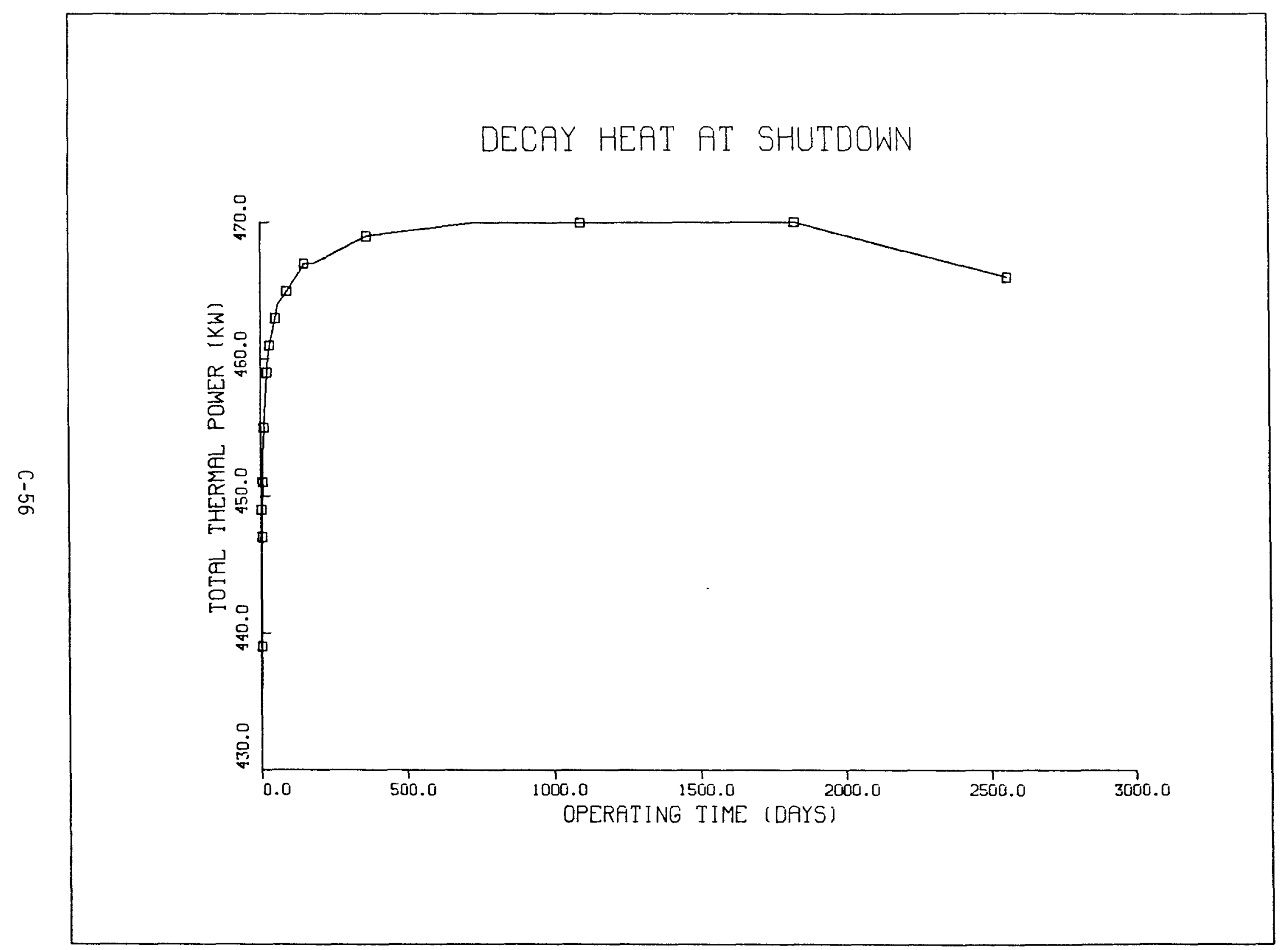

Fig. 6. Decay heat at shutdown. 


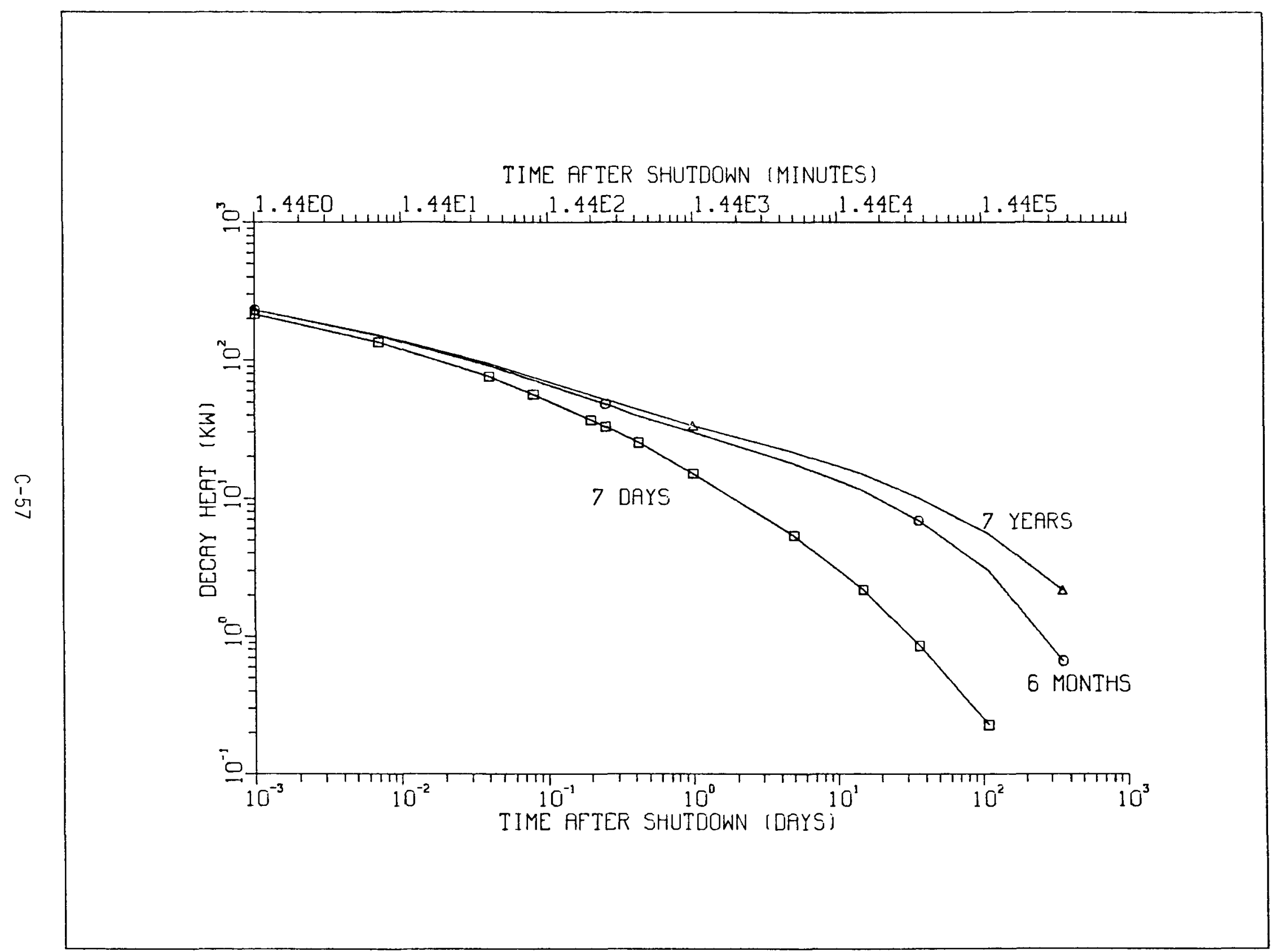

Fig. 7. Decay heat as a function of time after shutdown. 


\section{C8.4 Reference C.15 from Section C.7}

BASES FOR TOXICOLOGICAL GUIDELINES FOR LIQUID METAL AEROSOLS

A Protective Guideline (PG) is an airborne concentration below which the general public could be exposed for up to one hour without experiencing or developing irreversible health effects, or effects which could impair an individual's ability to take protective action. These levels, established by the American Industrial Hygiene Association, are normally based on a level defined as Immediately Dangerous to Life or Health (IDLH).

Although a PG has not been established for sodium and 1 ithium aerosols, a bounding PG can be developed by using the IOLH for the hydroxide forms of the materials. For the bounding assessment, all the material is assumed to be converted to hydroxide. This would not normally be the case, because the conversion to hydroxide occurs only in the presence of water. Even if large quantities of water were present, some of the metal would react with oxygen in the air forming an alkali metal oxide. (1) One motivation for assuming all of the metal is converted to hydroxide is that published data on IDLH concentration 1 imits of $200 \mathrm{mg} / \mathrm{m}^{3}$ for hydroxides exist. (2\&3) A limiting concentration for oxides has been proposed by the American Conference of Governmental Industrial Hygienists, but it is more than an order of magnitude less restrictive than the corresponding limit for hydroxide. (1)

With this as a basis, the IDLH of $200 \mathrm{mg} / \mathrm{m}^{3}$ has been used as a maximum accident exposure concentration for onsite (worker) exposure. As an added measure of conservativism, this has been reduced by a factor of 5 to $40 \mathrm{mg} / \mathrm{m}^{3}$ to develop a maximum accident concentration for offsite (general public) exposure.

1. J. L. Ballif (Ed.), "Liquid Metals Fire Control Engineering Handbook," HEDL-TME-79-17, February 1979.

2. "Documentation of Threshold Limit Values," rev. ed., American Conference of Governmental Industrial Hygienists, 1014 Broadway, Cincinnati, Ohio, 1966.

3. "NIOSH/OSHA Pocket Guide to Chemical Hazards," DHEW (NIOSH) Publication No. 78-210, reprinted January 1980. 
A P PENDIX D

SP-100 CHRONIC RELEASE

DOSE ANALYSIS DOCUMENTATION

D-1 
Blank Page 


\section{SP-100 CHRONIC RELEASE DOSE ANALYSIS DOCUMENTATION}

An analysis of the radiological impacts of chronic releases from the SP-100 GES Test operation concluded that the impacts would be negligible. The maximum whole body dose commitment to the nearest resident is $4.5 \times 10^{-4}$ mrem as compared to the 40 CFR $61.92^{(\mathrm{D} .1)}$ whole-body 1 imit of $25 \mathrm{mrem} / \mathrm{yr}$. The following is a brief documentation of the techniques and assumptions applied.

Code Documentation

Computer Codes: $\quad$ DACRIN (Rev. 1.2, 1980) for inhalation doses KRONIC $(9 / 86)$ for submersion doses

PABLM (Version 2.2, 10/80) for ingestion and ground contamination doses

Calculated Doses: Chronic inhalation, submersion, ingestion, and ground contamination exposure doses for the nearest resident (assumed to be located on the east bank of the Columbia River, $1250 \mathrm{~m}$ from the 300 Area) and the population within $80 \mathrm{~km}$ (1990 projection from Reference 0.2$)$; 50-year dose commitment from one year of operation

Files Addressed: $\quad$ Radionuclide Library (RMDLIB) (1/15/81)

Organ Data Library (2/5/81)

Energy Probability Library (9/86)

Food Transfer Factor Library (8/26/82)

External Dose Factor Library (3/15/78)

Bioaccumulation Library (9/86)

Assumptions

Release Height: Ground level 
Meteorology:

Individual Doses: Annual average dispersion factor $(x / Q)$ for ground leve 1 release ${ }^{(D .2)}$ for inhalation, ingestion, and ground contamination:

$$
3.6 \mathrm{E}-6 \mathrm{~s} / \mathrm{m}^{3} \text { at } 1.25 \mathrm{~km} \text { east }
$$

Population Doses: Population-weighted annual average dispersion factor for ground level release (dispersion factor data from Reference D.3 and 1990 population data from Reference D.2) for inhalation, ingestion, and ground contamination:

$$
9.6 \mathrm{E}-3 \text { person-s } / \mathrm{m}^{3}
$$

Submersion Doses: $\quad$ Based on site-specific joint frequencies of windspeed and direction as a function of stability class for both individual and population doses (D.4)

Removal Mechanisms: None

Release Time: Continuous during operation

Source Terms: $\quad 3.7 \mathrm{Ci}$ argon -41 per $\mathrm{yr}$

$4.7 \times 10^{-2}$ Ci tritium per $y r$ 
Consequences

TABLE D. 1

50-YEAR DOSE COMMITMENTS FROM ONE YEAR OF OPERATION

Nearest Resident (rem)

\begin{tabular}{|c|c|c|c|c|}
\hline Type & $\begin{array}{r}\text { Whole } \\
\text { Body }\end{array}$ & Bone & Lung & Thyroid \\
\hline Inhalation & $3.1 E-9$ & 0 & $3.1 \mathrm{E}-9$ & $3.1 E-9$ \\
\hline Submersion & $4.2 E-7$ & $4.2 E-7$ & $4.2 E-7$ & $4.2 E-7$ \\
\hline $\begin{array}{l}\text { Ingestion/ } \\
\text { Ground Exposure } \\
\text { TOTAL }\end{array}$ & $\frac{3.0 \mathrm{E}-8}{4.5 \mathrm{E}-7}$ & $\frac{0}{4.2 E-7}$ & $\frac{3.0 \mathrm{E}-8}{4.5 \mathrm{E}-7}$ & $\frac{3.0 E-8}{4.5 E-7}$ \\
\hline
\end{tabular}

Population Within $80 \mathrm{~km}$ (person-rem)

\begin{tabular}{llccc} 
Inhalation & $8.3 \mathrm{E}-6$ & 0 & $8.3 \mathrm{E}-6$ & $8.3 \mathrm{E}-6$ \\
Submersion & $2.7 \mathrm{E}-3$ & $2.7 \mathrm{E}-3$ & $2.7 \mathrm{E}-3$ & $2.7 \mathrm{E}-3$ \\
$\begin{array}{l}\text { Ingestion } / \\
\text { Ground Exposure }\end{array}$ & $4.17 \mathrm{E}-5$ & 0 & $4.1 \mathrm{E}-5$ & $4.1 \mathrm{E}-5$ \\
\hline TOTAL & $\overline{2.7 \mathrm{E}-3}$ & $\overline{2.7 \mathrm{E}-3}$ & $\overline{2.7 \mathrm{E}-3}$ & $\overline{2.7 \mathrm{E}-3}$
\end{tabular}


D. 1 Code of Federal Regulations, "National Emission Standards for Hazardous Air Pollutants," 40 CFR 61, US Environmental Protection Agency, Washington, DC, 1985.

D.2 D. J. Sommer, R. G. Rau, and D. C. Robinson, Population Estimates for the Areas Within a 50-Mile Radius of Four Reference Points on the Hanford Site, PNL-4010, Pacific Northwest Laboratory, Richland, WA, November 1981 .

D.3 W. D. McCormack, J. V. Ramsde11, and B. A. Napier, Hanford Dose Overview Program: Standardized Methods and Data for Hanford Environmental Dose Calculations, PNL-3777, Rev. 1, Pacific Northwest Laboratory, Richland, WA, May 1984.

D.4 B. A. Napier, Standardized Input for Hanford Environmental Impact Statements - Part I, PNL-3509, Pacific Northwest Laboratory, Richland, WA, May 1981. 


$$
\text { A P P E N D I } E
$$

SP-100 GROUND ENGINEERING SYSTEM

REACTOR TEST SITE SELECTION ENVIRONMENT FACTORS

$E-7$ 
Blank Page 
DATE August 1,1986

REPLY TO NE-521

ATTN OF

SP-100 Ground Engineering System (GES) Reactor Test Site Selection Environment Factors

SP-100 GES Program File

The attached report constitutes documentation of consideration given to environmental factors in the site evaluation/selection process for the GES reactor assembly test. It describes the environmental factors and summarizes their application at each of the five candidate sites for which proposals were received. The conclusions indicate that environmental factors were included throughout the process, but that they were not governing in the final selection of the preferred site.

This report will be included as an appendix to the required environmental document for the reactor assembly test at the Hanford Engineering Development Laboratory which has been designated as the preferred test site.

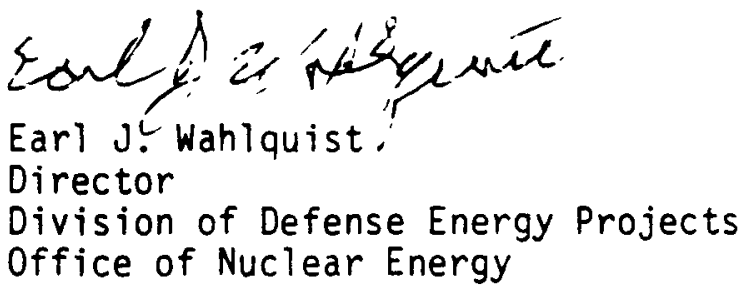

Attachment

cc w/att:

Ray Pelletier, EH-23

Ken Absher, RL

Vince Truscel10, JPL

Walt Von Flue, SAN 


\section{SP-100 GROUND ENGINEERING SYSTEM \\ GROUND REACTOR TEST SITE SELECTION ENVIRONMENTAL FACTORS}

\section{INTRODUCTION}

The goal of the SP-100 program is to develop multi-hundred kilowatt electric space reactor power system technology to support future civil and military space programs. One of the important elements of this program is SP-100 Ground Engineering System (GES) testing to demonstrate the viability, safety, performance and dependability of the technology. One task within this program effort involves the operation of a test reactor in a simulated space environment. The selected site for this reactor test program should offer the best combination of facilities, personnel, technical expertise, commitment, cost and schedule.

The process of arriving at a preferred site recommendation involved a series of steps. These steps included the development and approval of a site selection plan, the distribution of the facility development requirements and a request for formal proposals. These were followed by the designation of a site Evaluation committee (SEC) and a Technical Advisory Panel (TAP) on March 20, and the receipt of proposals from five sites by May 1. After site visits during May 1985, an evaluation meeting was held by TAP and SEC in early June.

These steps summarize the site evaluation/selection process with particular emphasis on the consideration given to environmental factors throughout the process. Succeeding sections present the objectives of the GES and the requirements used in the site evaluation/selection criteria and the evaluation of the site proposals against these criteria, a review of the environmental considerations, and the conclusions drawn.

\section{SP-100 GES OBJECTIVES AND REQUIREMENTS}

Although the SP-100 GES test effort is an essential element in the development process leading to a space power system, its objectives and scope are limited to ground tests of subsystems and components. The scope of these environmental evaluations are directly related to the SP-100 GES objectives and requirements.

A. SP-100 GES Program Objectives

The SP-100 GES test effort is one element of the research and development activities which are expected to lead to the design, engineering dovelopment, and production of a flight-qualified 
space power source of net electrical power output of from tens of kilowatts to one megawatt. At the time of site evaluation and selection, no specific space missions were identified, but a specific power level for the ground reactor test $(300 \mathrm{kWe})$ had been determined. The program's intent is to test the ground engineering system at the subsystem level; that is, a fully integrated power system test is not planned.

The schedule calls for completion of the GES project by october 1991. Therefore, only existing sites with facilities that could be modified to meet this schedule were considered.

B. Site Operator Requirements

In support of the request for formal proposals, facility requirements were compiled by the TAP.

Although most of these were based on the functional needs of the ground test effort, a number of them, which are to be fulfilled by the site operator, have environmental implications. These include, among others:

- The assurance that all facilities, equipment and systems are constructed, installed, operated and maintained in accordance with applicable DOE standards.

- The preparation and implementation of a safety plan, incorporating both the test approval documents and the site operational safety documents for both nuclear and industrial safety.

- Emergency response preparedness and implementation.

- The provision of means for reliable heat rejection from the reactor under normal operation (from 500 to $7600 \mathrm{~kW}$ of thermal power) as well as for emergency core cooling.

- The provision of a vacuum test chamber capable of reliable operation (up to 24 months) at a vacuum level of $1.3 \mathrm{E}-06 \mathrm{~Pa}(1.9 \mathrm{E}-10 \mathrm{psi})$ and also holding an absolute internal pressure of $200 \mathrm{kPa}(29 \mathrm{psia})$.

- Shielding of test equipment and normal work areas to permit manned access and exposure limits within acceptable limits.

- A secondary containment to accommodate an internal pressure of $140 \mathrm{kPa}(20.3 \mathrm{psia})$ and retain all radioactivity resulting from presumed design basis accidents.

- The provision of adequate support facilities, including waste disposal services for radioactive and hazardous wastes. 
Additionally, general site descriptive information was requested as well as information on the approval process to be applied to the GES test program at the respective sites. The latter included:

- Listing of applicable, currently approved site and facility documents.

- Identification of new or revised documents requiring approval prior to facility modification or test program implementation.

- Flow chart of principal activities needed to obtain required approvals together with cost and time estimates.

- Summary of previous or current problems, or potentially unresolved issues that could impact the schedule or cost of the approval process.

- Summary of anticipated costs and overall schedule associated with the approval process.

\section{SITE EVALUATION/SELECTION PROCESS}

The site evaluation/selection process involved the establishment of evaluation criteria, and the assessment by the SEC and TAP of the submissions by each of five candidate DOE sites (HEDL, INEL, NTS, ORNL, and SNLA) against these criteria. This section presents a summary of the evaluation process with emphasis on the environmental factors which were considered.

A. Site Evaluation Criteria

Five major criteria, or attributes, were established against which each proposal and candidate site was evaluated.

These are:

1) Facilities and Equipment - Identified twelve elements of facilities and equipment envisioned to be essential for the ground reactor test as tabulated below. For each element, the information for each site on technical approach, capital equipment costs and schedules, facility modification costs and schedule, and operational costs was evaluated.

Facilities and Equipment Evaluated

A. Heat Rejection System

B. Liquid Metal Handling

C. Vacuum Test Chamber

D. Containment

E. Shielding

F. Controls and Data

G. Test Article Assembly Area
H. Post Test Inspection/

Examination

I. Waste Disposal

J. Test Article Emergency Protection

K. Support Facilities

L. Safeguards \& Security 
2) Approval to Operate - The site-provided information on the process required to obtain approval to operate the ground reactor test was evaluated. Particular areas considered included cost, schedule and site specific needs for environmental documentation or other approvals prior to modification and testing, as well as programmatic risks arising from institutional, political, public safety, or environmental sensitivities.

3) Personnel and organization - The evaluation considered the management organization proposed to deal with the SP-100 GES testing, the key individuals identified in the organization, and their qualifications. Capability and availability of personnel experienced in both reactor test operations and test support were evaluated.

4) Integration with other Activities - Information on the synergism with other programs (either current or planned) at the respective sites, and on the capability to perform other activities associated with the sp-100 Program was evaluated.

5) Management Commitment - Evaluations of each site were made of the priority assigned to the SP-100 GES program, the existence of conflicting programs, the management systems to be used in implementing the program, and prior experience with projects of this size and complexity.

Following a review of the proposals and visits to each of the sites, the SEC reached a consensus listing of the strengths and weaknesses of each site with respect to each attribute identified above. The TAP produced an analysis of the proposed facility modifications and the associated costs which was incorporated into the SEC evaluation.

In these evaluations environmental factors did not constitute a major discriminator amongst the sites. The use of existing facilities, with an emphasis on limited modifications for both cost and schedular reasons, suggest very limited construction impacts. The constrained nature of the test program and its duration, as well as the location of the test program activity in the midst of other ongoing operations, would imply the incremental impact of the test program on the current site operational impacts to be minimal. Nevertheless, these factors were an element in the evaluation process and are presented in summary form for each of the candidate sites considered in the next section.

\section{B. Site Environmental Considerations}

For each of the sites, a summary of the environmental factors presented in the respective proposals is presented (in alphabetical order). followed by the SEC summary evaluation of the "Approval to Operate" criterion. 
1. Hanford Engineering Development Laboratory

a. Proposal Information Abstract

1) The proposed test site is Hanford's 300 Area, a DOE-owned, contractor operated site of about 400 acres, seven miles north of the Richland City Center. The existing building (309) proposed to be modified for SP-100 GES testing is a containment building previously designed and built for the now decommissioned PRTR, a 70 MWt reactor. Below-grade cells in that building are available to house the vacuum vessel and test article as well as auxiliary test systems. The steel containment vessel and concrete wall are structurally adequate for the seismic response spectra. No modifications of any facilities beyond Building 309 would be required.

2) The Hanford site is one of the most fully characterized and monitored in the nation. No additional monitoring or surveillance programs would be required for the GES program.

3) All wastes from the GES program can be disposed onsite in existing or currently planned waste system facilities.

4) The Hanford area has a relatively low population density, with the nearest residence about 1 mile east of the proposed test facility across the Columbia River. The nearest city water intake is the Richland city pumping station on the Columbia River about 4 miles downstream from the 300 Area.

b. SEC "Approval to Operate" Evaluation

The risks and impacts to the GES Program in obtaining "Approval to Operate" are judged minimal, based on the following factors:

1) HEDL has recent, relevant experience and a clear understanding of the regulatory requirements.

2) HEDL recent experience and its evaluation of GES refurbishment activities shows no significant safety or environmental issues, even considering the site location's relative proximity to the Richland City Center and the Columbia River.

3) Independent Operational Readiness Reviews are conducted to verify compliance with system and safety requirements and all procedures exist.

4) There is high political and public acceptance of nuclear activities in the Hanford area.

5) The Hanford site is one of the most highly characterized and monitored sites with respect to environmental and safety concerns. 


\section{Idaho National Engineering Laboratory}

a. Proposal Information Abstract

1) INEL proposes using the LOFT reactor containment facility at the Idaho Test site to conduct the GES test. The test article would be assembled at the TAN 607 facility and mounted on a Mobile Test Assembly (MTA) for transport between TAN 607 and LOFT containment on a four-rail track. The LOFT containment is more than adequate for the purposes of this test program. All of the test support hardware would be mounted on the MTA and the reactor would be located above grade. Only minor facility modifications would be required.

2) The remoteness of the INEL site has been a principal reason for its consideration as a test site for all new U.S. reactor types. The nearest site boundary is about $10 \mathrm{~km}(6.2 \mathrm{miles})$ distant.

3) Disposal of radioactive wastes generated by the SP-100 GES program can be accomplished at existing on-site INEL facilities, and their incremental impact is small.

4) No significant socioeconomic or demographic impacts are expected due to the small number of personnel required to construct and operate the facility, nor are significant incremental impacts envisioned from routine releases. Severe accident releases are expected to fall within the inventory envelope evaluated for the LOFT core failure, and no significant radiological impacts are expected.

b. SEC "Approval to Operate Evaluation

The risks and impacts to the GES program in obtaining "Approval to Operate" are judged minimal, based on the following factors:

1) The INEL team exhibits excellent understanding of the required approval process, including development of preliminary plans and outlines of documents needed for obtaining such approvals.

2) The remote location.

3) State and local public support.

4) The existence of prior environmental assessments of the area.

5) Previous approval of the LOFT containment facility for higher power reactors. 
a. Proposal Information Abstract

1) The proposed test site is Area 25 of the Nevada Test Site known as the Nevada Research and Development Area (NRDA) and located about 90 miles from Las Vegas. The existing Engine Maintenance Assembly and Disassembly (E-MAD) complex, constructed in the mid-60s for the nuclear rocket engine project as part of the space Nuclear Propulsion Program, was proposed as the GES reactor test facility. Reactor shielding and vacuum system would be located in the Hot Bay, and assembly would take place in the clean assembly area of the E-MAD. E-MAD is currently being partially used in support of the LWR Spent Fuel dry storage R\&D program.

2) The site has perhaps the lowest population density of any area in the U.S., and an extensive environmental data base because of the previous and continuing uses of the NTS. Radiological monitoring programs are in existence which would encompass the SP-100 GES activities.

3) An EIS for the Nevada Test site was issued in 1977 (ERDA-1551) which addressed releases from fission sources greatly exceeding those contemplated for the SP-100 GES.

4) Waste disposal requirements can be accommodated onsite.

b. SEC "Approval to Operate" Evaluation

The risks and impacts to the GES Program in obtaining "Approval to Operate" are judged minimal, based on the following factors:

1) The location is among the most remote in the U.S.

2) State and local support for the SP-100 GES activities is outstanding.

Weaknesses of this site exist, however, and include the following factors:

3) The umbrella EIS (ERDA-1551) which includes discussion of testing a space nuclear power reactor of from 0.1 to $10 \mathrm{MW}$ in Area 25 may not include information relevant to the SP-100 GES test program.

4) NTS has no recent experience in obtaining approval to operate a nuclear reactor. 
4. Oak Ridge National Laboratory

a. Proposal Information Abstract

1) The proposed test site is the DOE-owned and controlled Thorium Uranium Recycle Facility (TURF), an existing hot cell complex in the Melton Valley security area at ORNL. TURF was originally built for the recycling of gas-cooled reactor fuel but has never been used. Two of the hot cells were proposed to be used for the vacuum test chamber and heat rejection systems. TURF is located about $1.6 \mathrm{~km}$ ( 1 mile) from the main ORNL site, about 10 miles from the city of Oak Ridge and about 20 miles from metropolitan knoxville.

2) The most significant facility modification would be the construction of a hardened control room along the wall of the TURF building. In addition, the structure would be strengthened to meet seismic and tornado criteria, and the cell holding the reactor vacuum chamber modified to accept it.

3) All wastes except spent fuel would be processed and disposed of on-site; spent fuel would be shipped off-site for reprocessing.

4) Formal environmental documentation (an EIS) would be prepared to assess the anticipated effects of the proposed project and facility.

b. SEC "Approval to Operate" Evaluation

ORNL's ability to obtain approval to operate is somewhat questionable from both technical and political perspectives, based on the following factors:

1) Although the local population is generally supportive of nuclear energy, there is no evidence that a new initiative would have state and local support similar to that afforded existing reactors.

2) There is no bona fide containment structure proposed and a significant population exists within 10 miles.

3) Although a PSAR and FSAR would be prepared for the SP-100 GES program, a general lack of understanding of environmental approval requirements existed and it was not clear whether an EA or EIS would be necessary, nor were the cost and time required for an EIS identified. 
5. Sandia National Laboratories at Albuquerque

a. Proposal Information Abstract

1) The proposed test site is owned and controlled by DOE in Technical Area $V$ within the Kirtland Air Force Base Military Reservation and is located about $22 \mathrm{~km}$ (14 miles) from the metropolitan area of Albuquerque, New Mexico. The existing Sandia Engineering Reactor Facility (SER) proposed to be modified for SP-100 GES testing, was previously designed for a 5 MWt steady-state, water-cooled reactor. The Radiation Test Cell of the SER facility would house a new containment vessel, vacuum vessel, and the test article. The high bay above the Radiation Test cell would be converted to a hot cell for servicing the test article and two new rooms would be added to house heat rejection systems.

2) The proposed site is isolated within the Kirtland Reservation, with the nearest privately owned land or open access public facilities located $6.4 \mathrm{~km} / 4$ miles) away.

3) Most waste disposal would be accomplished on-site.

b. SEC "Approval to Operate" Evaluation

SNLA has assumed in the cost estimate and schedule that a special environmental assessment and a special environmental impact statement are not required for SP-100. The most recent environmental-type document prepared is the environmental impact assessment, May 1977, which addresses activities within SNLA. Since this document is eight years old, and circumstances have tightened environmental requirements, delays in obtaining approval to operate are considered a high risk, particularly when considered with the following factors:

1) Although a PSAR, FSAR, final technical specifications approval and preoperational audits will be performed, and a very capable staff exists to perform the necessary safety analysis reviews required, if SP-100 GES activities and potential hazards are not within the scope of the existing site environmental assessment, significant cost and schedule delays could occur.

2) Members of the general public have access to a golf course approximately one mile from the test facility.

3) It is not obvious that state and local governments are in support of SP-100 GES testing at SNLA, which could impact the schedule. 
IV. CONCLUSIONS

Based on the considerations of all of the evaluation attributes identified earlier, the SEC narrowed the preferred sites to HEDL and INEL. Both of these sites proposed the use of a facility with a containment building; and, as indicated earlier, although environmental considerations were not governing, they were considered in arriving at these recommendations of preferred sites.

On November 21, 1985 the Department of Energy selected the Hanford Site as the preferred site for the SP-100 GES reactor ground test. Recognizing that environmental factors do not significantly discriminate between HEDL and INEL, the selection was largely based on other factors. 
A P P E D I X F

MEMORANDUM: RADIATION STANDARDS FOR PROTECTION

OF THE PUBLIC IN THE VICINITY OF DOE FACILITIES

$\mathrm{F}-1$ 
Blank Page 
ron: 2329

United States Government

Department of Energy

memorandum

DATE NUG 51985

AEPLY TO

ATTN OF.

E.4 -24

SUREET

Radiation Standards for Protection of the Public in the

To. Vicinity of DOE gacilities

See Attached List

It is DOE policy to follow the guidance of the National Council on Radiation Protection and Measurements (NCRP) to the fullest extent practicable with respect to radiation protection standards. A comprehensive revision of previous NCRP recommendations on a basic radiation protection system is still under development. However, current NCRP guidance is available regarding protection of the public in its september i8, 1984, advise to the Environmental Protection Agency published under the title "Contzol of Air Emissions of Radionuclides" (Attachment 1). In this document the NCRP endorses the recommendation of the International Commission on Radiological Protection (ICRP) to limit the continuous exposure of any member of the pubilic from other than medical sources and natural background to 100 mrem per year whole body dose-equivalent. The previously recommended limit of $500 \mathrm{mrem}$ per year is retained for noncontinuous exposures. This recommendation is now adcpted as an interim standard for DOE environmental activities for al exposure pathways (see Attachment 2).

The NCRP, unlike the ICRP, has not as yet finalized its recommendations for limiting risk from radiation exposures on a basis of equivalent total body exposure, as opposed to previous recommendations aimed at controlling exposuze to a critical organ. Pending such guidance from the NCRP, it is deemed appropriate at this time to implement this newer concept, as embodied in ICRP Publications No. 26 et seq., fOr DOE envizonmental programs.

By memorandun dated septemiber 17, 1984, R. E. Tiller distributed a proposed amendment to DOE Order 5480.1A for informal zeview by $H Q$ and Field offices. The amendment incorporated the radiation standards now being adopred. Headquarters and field comments generally supported the proposed standards, but did not support proposed procedures for implementing ALARA (As Low as Reasonably Acnievabie). Attachment 2 to this memorandum is now efsective. It adopts the sadiation standards proposed in the septemioer 17 
memorandum, the air emission standards of 40 CER 61 , Subpart $H$, and establishes a review threshold and reporting requirements to provide assurance that the iimits will be met. Revision of associated procedural requizements in DOE Order 5480.1A, including ALARA implementing procedures, will be accomplished later.

In concert with this action, EH is preparing to publish tables of intake to dose conversion factors based on ICRP publication 30 models and parameters to be used by DOE environmental programs in calculating dose to memoers of the public in Cy 1985 and future years. A copy of the final draft of these tables is attached for your information and use (Attachment 3 ). The dose conversion factors are to be used unless computerized dose models already incorporate the ICRP publication 30 models and parameters or, in the case of air pathways, the facility uses EPA's AIRDOS/RADRISR models or other EPA approved model. In view of the possibility of conflicting parameter selections, particularly the use of 70 years rather than 50 years as the period for calculating committed doses, the use of such alternative site-specific models should be brought to the attention of the office of Operational Safety for approval.

Based on comments in response to the september 17,1984, memorandum and our extensive coordination with program offices at Headquarters, we believe that all substantive problems relating to these standards have been resolved. Any qufstions concerning this matter should be direfted to carl G. Weity, office of operational safety (ET'S 233 $\$ 5642$ ).

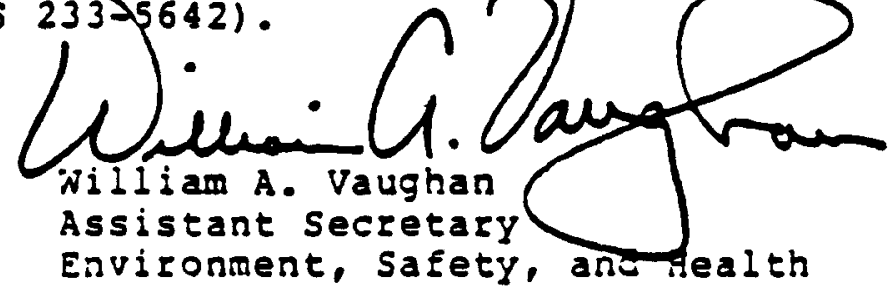

\section{Attachments}

cC: W. W. HoOver, DP -1

A. W. Trivelpiece, ER-i

J. W. Vaughan, Jr., NE-1

EH Office Directors 
| Proif CIION ANU mitasunemints

\section{CONTROL OF AIR EMISSIONS OF' RADIONUCLIDES}

The National Council on Radiation Protection and Measurements (NCIRI) has considered the problems raisud by the Congressional requirement that the Environmental I'rotection Agency (F,I'A) develop standards for rudionuclitles as part of the National kimission Standarils for 11:azarilouy Air Pollutants. The El'A has proposed ruley uniler 40 CFIR l'art 61 and the NCIII l'resident, with the alvice of an ad hoc group of Council menibers, has commenled on these proposals by correspondence and during lil'A and Congressional Ilearings. The Council cunsidery it desivable at this time to present positive recommentations batseel on published Council Reports and current work in jurogress.

'The NClil' Scientific Committee 1 on Masic Ratlintion Prolection Crileria has olrafted a rejort defining the rolevant reconmemelations of the Council. While this dran is still unyulolished, sume of the pertiment numerical valurs

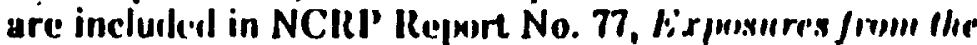

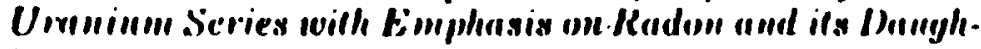
Prors.

These are detailed here.

1. The limil of 500 mreon whole body dose equivalent in a year, not including medical and natural background radiation, is still recommencled for indiviluals in the poppulation when the exposure is not continuous. As a corollary, the NCIRP alvises remetlial netion, where possible, whin the external whole tody doste equivalonit exceeds s, (U) mrem/yciar from all environmental sources, including nillural loilek!roumil.

2. The rocoumunemded limit for cont mumus axposure of an indivislual in the poppulation to extermial ratlintion is 100 mrem/year whole bodly dose equivalent, mol including ex- posure from natural backgrounil and medical procedures. A dose equivalent rate of IIX) $\mathrm{mrem} / \mathrm{year}$ is considlerml to he associated with a lifetine risk of developing cancer of aboul one in a thousand.

3. These recommendations on limits are only part of a cotal systeon of dosse limitation which must also inclucle justification and considerations of ALARA (As Low As Reansunably Achicevable).

While the NCIRI' has in the past specifically declimed to introduce a sub-set of linnits, it is sympiathetic to the noerds of regulatory bodies who must control inclivislual sourcess of ralliation expossure. In particular, it is neerssiary to comsirler the: situation where a menoluer of the pullic may be exposecl to radiation from more than one of the comerolled sourcess.

In looking at the possibility of multiple expmsures, it secems that large installiations which coulil causc expmsurss that are a significant fraction of the $1(1)$ mreon/year limit are unlikely to be geographically liceaterl in such a manner that the sum of the expmsinres from two sources wonld out werigh the exposures to inclivinluals closer to cillier of the seppirate sources. At the other end of the scalle, smiall installations that may be more clusely spaced shoulal pron. duro: unly relatively small "xposures, so that even the surn of their exposures would not approach the $100 \mathrm{mrem} /$ year limil for continuen] exposure.

The Council (NCICI') appreciates, however, that a rogulalory agency charged with protection of the public may consirler it necessary to regulate individlual sourems in oriler to ilssure that no imdividual receives a contimumus rad ial ion dese alove the IIW mrem/year recommenenlod limit. Thus, whenever the potential exists for an indivilual to exceond $25 \%$ of the limit, for whole-lnoly dise efunivalent from any single site, the site operator should be remuired to assure that the expmsure of the maximally expmesed indlividual frum all sources would not exceed 100 mrem/ycair on a continuous basis.

'Ilisis recommendation of the NC,RI' concerns whole- Imorly irractiation but the Council has also considerenl the situation for the exposure of imdividual organs, surh as lwung or Inule. Dose limits for individual orgins will necessatrily be higher than that for the whole borly in the inverser rallio of

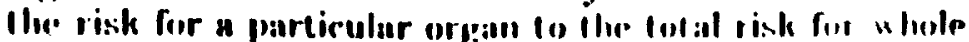
horly expusure. 
Radiation doses at the limits consilered are not remdily measured for continuous external whole-body exposure and such doses cannot be moasured directly for internal cmillers. Hence, it has been customary to use mathematical morlels to relate release quantities and the conmerpuent doses to iniliviluals in the public. This will still be necessary, but the NCKP recommends that implementation of stanclarils for air emission use models that are realistic, thornughly documented and capbalile of validation. While the incernal doses are ususilly estinnuted rather than measured, validating measurements call be made at steps in the environmiental chain of exposure that are cluser to the receptor than the releases. 'The meped for reulistic moolela is olsviuus; for example, a calculaled dose that is in errur by a factur of tive in either direction can either misjuclye the risk from exposure by a compjarable factor, or incre: ase the cost of cumpliance. This nubject is treated more $f_{1}$ " in tine recently released NCRP leport No. 76, Mintin:lenjicul

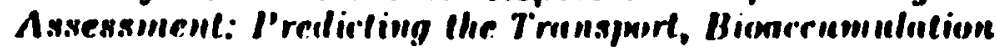
and Intake by Mun of Radionuclides Relensed to the Binviroument. 
OF THE PUBLIC IN THE VICINITY OF DOE FACILITIES

\section{A. DOSE LIMITS}

1. All Pathways

The effective dose equivalent for any member of the public from all routine DOE operations lnatural background and medical exposures excluded shall not exceed the values given below:

Occasional annual exposures ${ }^{3}$

Prolonged period of exposure 3

Effective dose equivalent ${ }^{2}$ mrem/year

( $\mathrm{s} v \mathrm{v} /$ year)

No invididual organ shall receive an annual dose equivalent in excess of $5 \mathrm{rem} / \mathrm{year}$ ( $50 \mathrm{msv} / \mathrm{year}$ ).

2. Air Pathway Only (Iimits of 40 CER 6I, subpart B)

Dose Equivalent mrerdyear

(msv/year)

Whole body dose Any organ
25

75
$(.25)$

$(.75)$
500

100

B. ACIION LEVEIS

1. To preclude an individual in the general population from receiving more than $100 \mathrm{mrem} /$ year effective dose equivalent, a DOE administrative action level is established at 25 $\mathrm{mrem} /$ year (excluding medical and natural background exposures) for its routine operations. This dose value is not a limit but an administrative threshold which will require a specific evaluation of the magnitude of identiEiable exposures to an exposed individual by the responsible DOE Field office. A copy of the evaluation redort will be transmitted to the relevant Program office(s) and the Deputy Assistant Secretary for Environment, Safety and Health, EH-10.

2. To precluce exceeding the aif pathway limits in A.2. above, Field offices shall notify the relevant Program of ice and EH-10 of calculated or anticipated doses to individual members of the population in excess of one half the specified dose ecuivalent limits.

1. Rourife JOE operations means nornal planned operations and does not include actual or potential zcciciental or unpianned releases.

2. Efsective dose equivalent will be expressed in rem (or miliizem) with the corzesponding value in sievere (or millisievers) in

jars:uhesis. As used in this standard, effecrive dose equivalent incluces joth the effective dose equivalent from external zaciation and the commitsed eftective dose equivalent to individual tissues from ingestion and inhalation during the calendar year.

3. Sor the purposes of these standards, a prolonged exposure will be one that lasts, or is predicted to last, longer than 5 years. 


\section{AS LOW AS REASONABLY ACHIEVABLE (ALARA)}

Field offices and contractors shall implement programs to assure that exposures resulting from DOE operations to members of the public are maintained as low as reasonably achievable. The ALARA programs shall be documented. Each Field office shall periodically audit contractor ALARA programs and contractor progress in attaining ALARA conditions. Assessments of ALARA must include best estimates of actual effective dose equivalent to individual members of the populations as well as collective dose equivalent to a distance of $80 \mathrm{kilometers}$ from the site.

\section{DEMONSTRATION OF COMPLIANCE}

Demonstration of compliance with these criteria shall normally be done by the following procedure:

a. Calculation of external exposure and internal intakes by use of effluent data and environmental pathway models approved by office of Operational Safety, Ed and/or environmental measurements.

b. Calculation of total effective dose equivalent using the Draft Final Committed Dose Equivalent Tables.

For DOE facilities with aif5orne releases subject to $40 \mathrm{CFR} 61$, Subpart $H$, the AIRDOS.-EPA model must be used except as otherwise approved by EPA. Compliance will be determined by calculation of the dose to members of the public at the point of maximum annual concentration in an unrestricted area where any member of the public resides or abides.

\section{E. ACEIDENTS}

The exposure limits given above are for routine DOE operations and are not intended for use as criteria to evaluate the acceptability of postulated accidents. Planning for the prevention or mitigation of accidents and their effects shali be accomplished in accordance with the requirements of DOE $5480.1 \mathrm{~A}$, Chapter V, "Safety of Nuclear Facilities" and Chapter VI, "Safety of Department of Energy Owned Reactors."

The unanticipated release of radioactivity (venting) from an underground nuclear weapons test is considered to be an accident. The release of radioactivity following an underground nuclear weapons test which is the result of planned samoling or reentry is not an accidental condition, and shall be controlled in accordance with the outlined standards. 
F. APPLICABLE DEFINITIONS

The following definitions are derived from ICRP Publication No. 42 (1984).

Dose equivalent - The product of the absorbed dose (in rads) in the tissue of interest, a quality factor (specified by the ICRP), and any other modifying factors specified by the ICRP.

Effective dose equivalent - A quantity defined by the sum

$$
\sum T W_{T}{ }^{B}
$$

where $W_{i}$ is the weighting factor specified by the ICRP to represeft the production of the stochastic risk resulting from irradiation of tissue $T$ to the total risk when the whole body is irradiated uniformly, and $\mathrm{H}_{\mathrm{T}}$ is the mean dose equivalent in tissue $T$. $H_{T}$ may be from dernal or internal sources. Values of $W_{T}$ have been specified by the ICRP and were used in preparing the draft final Committed Dose Equivalent Tables.

Committed dose equivalent - The time integral of the doseequivalent rate in a particular tissue following an intake. of radioactive material into the body. In keeping with ICRP recommendations, for DOE this period is set at 50 years.

Committed effective dose ecuivalent - The sum of the committed dose equivalents to individual tissues resulting from an intake. each multiplied by the appropriate weighting factor $\mathrm{w}_{\mathrm{T}}$.

Collective effective dose esuivalent - The collective effective dose equivalent is equal to the integrated sum of individual effective dose equivalents times the number of individuals exposed. For purposes of this directive only, the collective effective dose equivalent shall be truncated at $80 \mathrm{~km}$ distance from site boundaries and at 50 years following each year's release.

G. EFEECTIVE DATE

These criteria shall be used for all DOE dose calcularions effective July 1 , 1985 , including ansual sumary reports for $C Y 1985$ and subsequent years. 


\begin{tabular}{|c|c|c|}
\hline \multirow[t]{2}{*}{$\begin{array}{l}\text { DOE Order } 5480.1 A \\
\text { Radiation Standards } \\
\text { for Protection of the } \\
\text { Public in the Vicinity } \\
\text { of DOE Facilities, as } \\
\text { revised by the Vaughn } \\
\text { Memorandum of Aug. } 5,1986\end{array}$} & \multicolumn{2}{|c|}{$\begin{array}{lc}\text { Effective dose equivalents from all routine operations or releases: } \\
\text { Occasional annual exposures } & 500 \mathrm{mrem} / \mathrm{yr} \\
\text { Prolonged period of exposure } & 100 \mathrm{mrem} / \mathrm{yr} \\
\text { Action Level for reporting } & 25 \mathrm{mrem} / \mathrm{yr} \\
\text { Annual dose equivalent to an } & 5,000 \mathrm{mrem} \\
\text { individual organ. } & \end{array}$} \\
\hline & \multicolumn{2}{|c|}{ 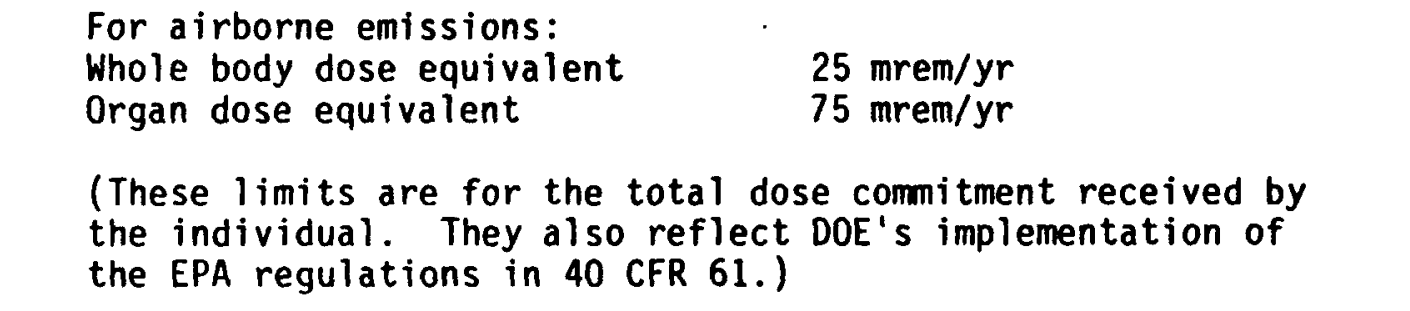 } \\
\hline $\begin{array}{l}\text { DOE Order } 5820.2 \\
\text { Radioactive Waste Management } \\
\text { "Lytle Memorandum" Proposed } \\
\text { Revision (interim performance } \\
\text { objective) (Feb. 19, 1986) }\end{array}$ & $\begin{array}{l}\text { Dose rate to the off-site public } \\
\text { near new LLW storage or disposal } \\
\text { facilities }\end{array}$ & $25 \mathrm{mrem} / \mathrm{yr}$ \\
\hline $\begin{array}{l}\text { NRC } 10 \text { CFR } 20 \\
\text { Standards for Protection } \\
\text { Against Radiation for } \\
\text { Individuals Who Are Exposed } \\
\text { Outside Normal Operations } \\
\text { Licensed by the NRC }\end{array}$ & $\begin{array}{l}\text { Whole body dose equivalent } \\
\text { (including blood-forming organs } \\
\text { and gonads) } \\
\text { Bone and thyroid } \\
\text { Other Organs }\end{array}$ & $\begin{array}{c}300 \mathrm{mrem} / \mathrm{yr} \\
1,500 \mathrm{mrem} / \mathrm{yr}\end{array}$ \\
\hline $\begin{array}{l}\text { Proposed Revision } \\
\text { (January } 9,1986 \text { ) } \\
\text { to NRC } 10 \text { CFR } 20\end{array}$ & $\begin{array}{l}\text { Effective dose equivalent } \\
\text { (Summation of external deep } \\
\text { dose equivalent to the whole } \\
\text { body and internal committed } \\
\text { effective dose equivalent. } \\
\text { Includes all known sources } \\
\text { except natural background, } \\
\text { medical diagnosis and therapy } \\
\text { and radioactive material } \\
\text { disposed into sanitary sewage.) }\end{array}$ & $500 \mathrm{mrem} / \mathrm{yr}$ \\
\hline
\end{tabular}


A P P E D I X G

CONCEPT SELECTION

G-1 
Blank Page 


\section{CONCEPT SELECTION}

\section{G.1 OBJECTIVE}

The objective of the SP-100 Program is to develop and demonstrate a compact nuclear reactor power supply that will provide a safe and highly reliable source of electric power (10s to $100 \mathrm{~s}$ of $\mathrm{kWe}$ ) for civil and military space applications in the mid-1990s and beyond. An important step in demonstrating this capability will be to conduct a ground test of the selected reactor concept.

\section{G.2 BACKGROUND}

The SP-100 Program was initiated in 1983 as an effort jointly sponsored by the Department of Energy (DOE), the Department of Defense (DOD), and the National Aeronautics and Space Administration (NASA). The goal of the initial phase of the program was to permit an informed decision by July 1985 on the technical and safety feasibility of a space nuclear reactor power system, which could provide electrical power in the range of $10 \mathrm{~s}$ to $100 \mathrm{~s}$ of $k$ We, and to determine the need for and timing of a ground engineering system test. The program is laid out in three phases:

Phase I Technology Assessment and Advancement Phase (FY 1983 FY 1985)

Phase II Technology Flight Readiness (Initiated FY 1986)

Phase III Flight System Production, Qualification, and Application

Personnel from the three participating federal agencies comprised a joint SP-100 Program Office during the first phase, while a Project office, managed by NASA's Jet Propulsion Laboratory (JPL), was made up of staff from JPL, DOE's Los Alamos National Laboratory (LANL), and NASA's Lewis Research Center. 
At the outset of Phase I, contracts were granted to study the feasibility, safety, and capabilities of a broad spectrum of space reactor and energy conversion system concepts. From this effort, three power system concepts were selected for continued study under separate contracts. All three concepts used a compact, fast spectrum liquid-metal-cooled nuclear reactor, but differed in the mechanism by which they converted the heat produced by the reactor to electricity. The three energy conversion concepts under study and the contractors performing the work were: 1) in-core thermionics, by a team of General Atomic (GA) Technologies and Martin Marietta Aerospace;

2) out-of-core thermoelectrics, by General Electric (GE) Company; and 3) Stirling engines (with a Brayton cycle option), by Rockwell International's Rocketdyne Division. All four concepts appeared to be feasible and promising.

\section{G.3 EVALUATION PRIORITY}

Surety (including environmental considerations) was identified as the highest priority throughout the evaluation process. The more detailed characteristics evaluated under surety (Safety and Safeguards) included:

Safety and Safeguards Criticality

Alternative Technology

Reentry Safety

Low Earth Orbit
Objective

Design the reactor to remain subcritical during accident conditions that include launch and ascent phase overpressure compaction, immersion/flooding, impact compaction, fire distortion of the geometry, and absorber removal.

Minimize the safety risks associated with alternative technology designs with fallback or advanced systems .

Maximize safety during the operation phase of the mission with inherent design features that would preclude subsequent safety problems during inadvertent entry. Must meet the reentry criteria of either dispersion or remaining intact.

Minimize the safety risks for low earth orbit missions including consideration of disposal options (boost to higher orbit), unplanned reentry, permanent end-of-life shutdown, operational safety, and reliability of safety systems. 
Safety and Safeguards

Space Transportation

System (STS) Safety

Requirements

Reliability of

Safety Systems

Operational Safety

Permanent End-ofLife Shutdown

Hazardous Substances

Safeguards
Objective

Minimize the potential effect of the SP-100 on the STS and the crew.

Maximize the reliability of the safety systems to optimize the safety and performance of the SP-100 during operation.

Maximize safety during the operational phase of the mission with inherent design features including consideration of startup neutronics and neutron stability, ability to remove decay heat passively, and core melt energetics and migration.

Maximize the reliability of this function, thereby minimizing the possibility of further criticality and the buildup of the fission product inventory before possible reentry.

Minimize the exposure of onsite personnel and the public to hazardous substances. In addition, minimize environmental effects from all mission phases.

Minimize the potential for diversion of the special nuclear material and prevent its conversion into a weapon, subsequent to an inadvertent reentry.

\section{G.4}

SP-100 SYSTEM SELECTION

In August 1985, the SP-100 Steering Committee formally selected the reactor thermoelectric concept for engineering development and ground testing during Phase II of the SP-100 Program. The purpose of this section is to summarize the decision process, with particular emphasis on the consideration given to safety and environmental factors in the process.

\section{G.4.1 Selection Process}

The process involved several steps, the first of which was development and approval of an SP-100 System Selection Process, which identified a Prioritized Set of Competing Design Characteristics (PCDC) and weighting factors for each. The PCDCs are identified below in order of priority, along with brief summaries of their objectives. 
Design Characteristic

Surety

Performance/Risk

Growth/Risk

Survivability

Cost/Schedule/Risk

User Interface

Operations Utility

Functions
Objective

Determine ability of nuclear power system to meet and/or exceed the safety and safeguards requirements for a system to be launched and used in space. (A subcriterion was to minimize environmental effects from all mission phases.

Determine the confidence of the power system concept to meet the requirements as specific in the Preliminary Design Goals and Requirements.

Determine the ability of the system to accommodate varying mission power requirements.

Evaluate the capability of the power system to survive various threats that may arise from the environment or hostile action.

Evaluate the cost and time required to develop the subsystem for flight readiness.

Evaluate the user friendliness of the power subsystem in terms of minimizing the required interaction between ground personnel or the user spacecraft and the nuclear power system.

Evaluate the power system's ease of operations, reliability, and system responsiveness in meeting operation requirements.

The risk element identified with the performance, growth, and cost/schedule design characteristics addressed the confidence level with which the requirements of these design characteristics could be met based on factors such as the maturity of the technologies, the planned development schedule, and the required testing approach.

All design characteristics were evaluated from the perspectives of prelaunch activities and ultimate use in space. Though specific missions were not identified, the decision process focussed on ultimate use and not on the interim testing that would take place in the Ground Engineering System element of the program. 
The next step in the system concept selection process was to distribute the PCDC and specific criteria to the system design contractors with a request to evaluate their designs against design requirements and criteria. The request informed the contractors that the final system design should meet these requirements and that the information which they submitted would be used in the system selection process. As the third step in the process, the three system designers submitted their surety evaluations as the selection procedure required.

\section{G.4.2 Candidate Concepts}

The four candidate power systems concepts were reactor/thermionics, reactor/ thermoelectrics, reactor/Stirling cycle, and reactor/Brayton cycle. Following is a description of the four concepts.

\section{G.4.2.1 In-Core Thermionic Reactor System}

The in-core thermionic (TI) concept was developed by both GA Technologies and Martin Marietta Aerospace (see Figure G.1). The primary advantages of the TI system is the relatively high efficiencies ( $9 \%$ to $11 \%$ ) and the high reject temperatures. The Phase I thermionic element consisted of uraniumoxide $\left(\mathrm{UO}_{2}\right)$ fuel operating at a temperature of $1750 \mathrm{~K}\left(3180^{\circ} \mathrm{F}\right)$ surrounded by a CVD tungsten emitter. The sheath insulator was Nb-YAG-Nb-1\%Zr operating at a temperature of $1100 \mathrm{~K}\left(2010^{\circ} \mathrm{F}\right)$ with $\pm 50 \mathrm{~V}$. The maximum fue 1 burnup was $2 \%$. Sodium-potassium (NaK) was used for the system coolant. The reactor outlet temperature was $1100 \mathrm{~K}\left(2010^{\circ} \mathrm{F}\right)$. The system was launched with coolant in the liquid state (which did not require thaw on orbit). One of the disadvantages of launching liquid is the requirement to double-contain the liquid if it is launched on the shuttle and the system may require energy input to keep it liquid during launch. The system was designed with both a single electro- magnetic (EM) pump and a single thermoelectric electromagnetic (TEM) pump (one out of two was required to perform the mission). The NaK transferred the waste heat to a sodium heat pipe radiator with $\mathrm{Nb}-1 \% \mathrm{Zr}$ armor. There was a $25 \mathrm{-m}$ separation between the center of the core and the user plane. The system was designed to deliver $100 \mathrm{Vdc}$ to the user module. 


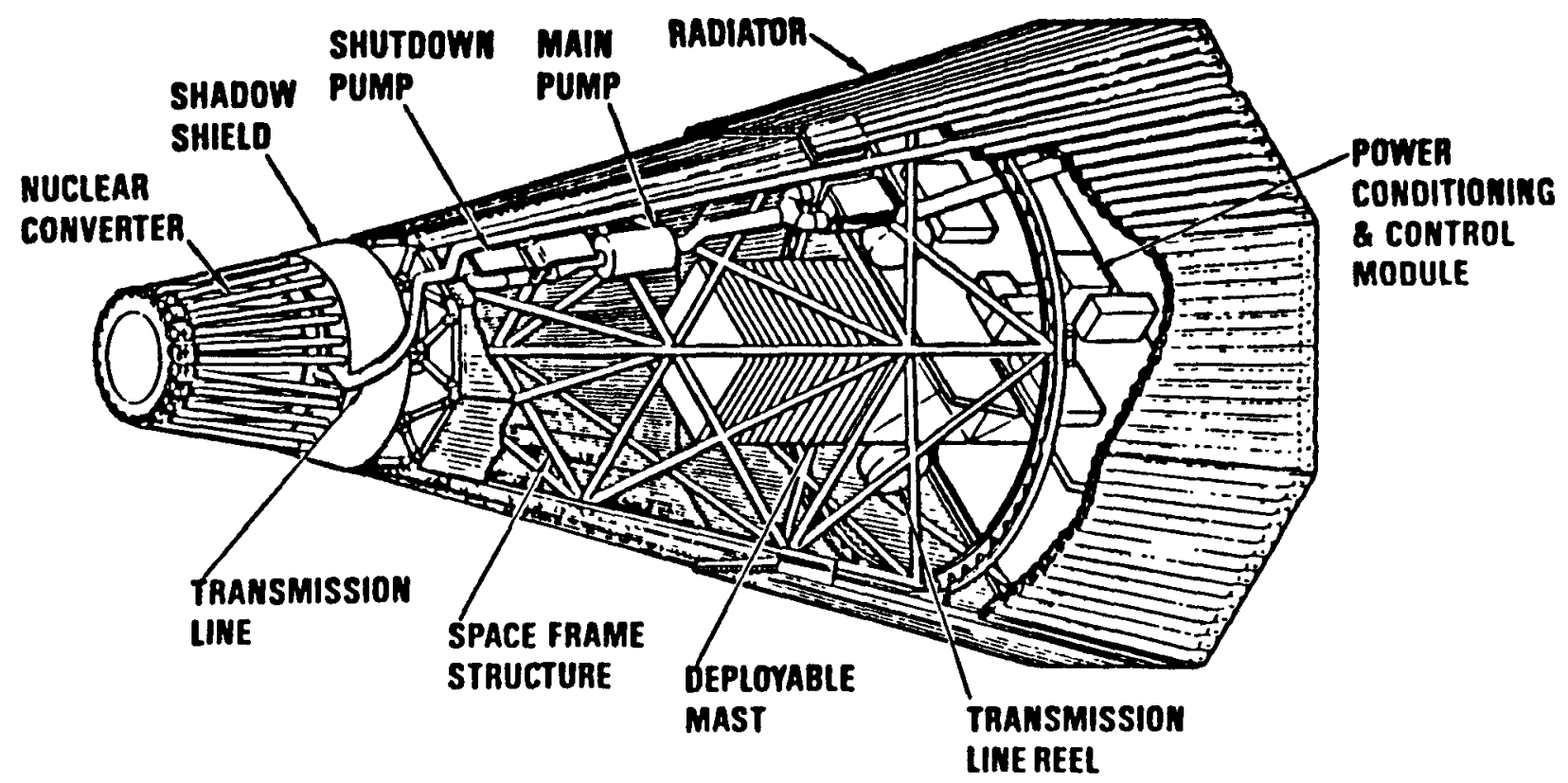

FIGURE G.1. Thermionic Reactor Systems.

A11 primary development issues for the thermionic reactor concept were within the reactor/converter module. This magnified the difficulty of the technology issues because of the cost, schedule, and technological concerns associated with testing and verification within a fast flux reactor. The following is the primary list of issues and concerns associated with the development of the thermionic concept.

- Long-Life Sheath Insulator -- Ceramic swelling/cracking caused by fast neutron damage and ionic conduction due to a large voltage potential $( \pm 50 \mathrm{~V})$.

- Fuel/Emitter Distortion -- Fuel swelling by fission gases distorts the emitter and causes eventual electrical shorting.

- Metal Ceramic Seal and Emitter to Collector Lead -- Swelling, cracking, and loss of hermeticity at dissimilar material joints where a single leak can open 12 cells; also attack on ceramic material by cesium vapor within the emitter/collector gap.

- Interconnects of Thermionic Fuel Elements -- Interconnects of TFEs prevented from shorting to NaK (ground). 
Each of the above technology issues affects technological performance and system lifetime. The fact that the TFE consisted of both the reactor core and the power conversion in one unit was both an advantage and disadvantage. It was advantageous because it could be designed and tested as a single, integrated unit. It was disadvantageous because it had to be tested within a reactor environment and, if the system failed, there was no simple fallback for either the reactor or the power conversion unit. Therefore, it was concluded that the thermionic concept had the greatest potential for growth and performance improvement but had higher risk at meeting lifetime and reliability requirements. It also was judged to have a low probability of meeting both cost and schedule constraints.

\section{G.4.2.2 Reactor/Thermoelectrics System}

The reactor/thermoelectrics (TE) concept was developed by GE (see Figure G.2). The primary advantages of the TE system are the large available database and the versatility of the reactor concepts use with alternate power conversion systems other than TEs. Uranium-nitride was proposed as the reactor fuel for Phase I with a tungsten barrier and $\mathrm{Nb}-1 \% \mathrm{Zr}$ cladding. The fuel was to operate at a temperature of $1400 \mathrm{~K}$ with a maximum burnup of $6 \%$. Lithium was the primary coolant, and the system was designed to be launched with solid lithium that would thaw in-orbit during reactor startup, an advantage because it simplified launch procedures. The reactor outlet temperature was $1350 \mathrm{~K}$. The coolant was circulated by three thermoelectricelectromagnetic (TEM) pumps (only two required). The TE cells, a hybrid of silicon and germanium ion compounds, were conductively coupled to the primary heat transport loop and the potassium heat pipe radiator. Titanium/ beryllium-aluminum was used for armoring the heat pipe radiator. The system was separated from the user by $40 \mathrm{~m}$, and the system delivered $200 \mathrm{Vdc}$ to the user module.

The following lists the primary issues and concerns associated with the TE concept:

- Long-life $1400 \mathrm{~K}$ UN-W-Nbl\%Zr Fuel Pin -- Fuel swelling and cladding failure at $6 \%$ burnup/7-yr lifetime and fuel/cladding/coolant chemical incompatibility. 


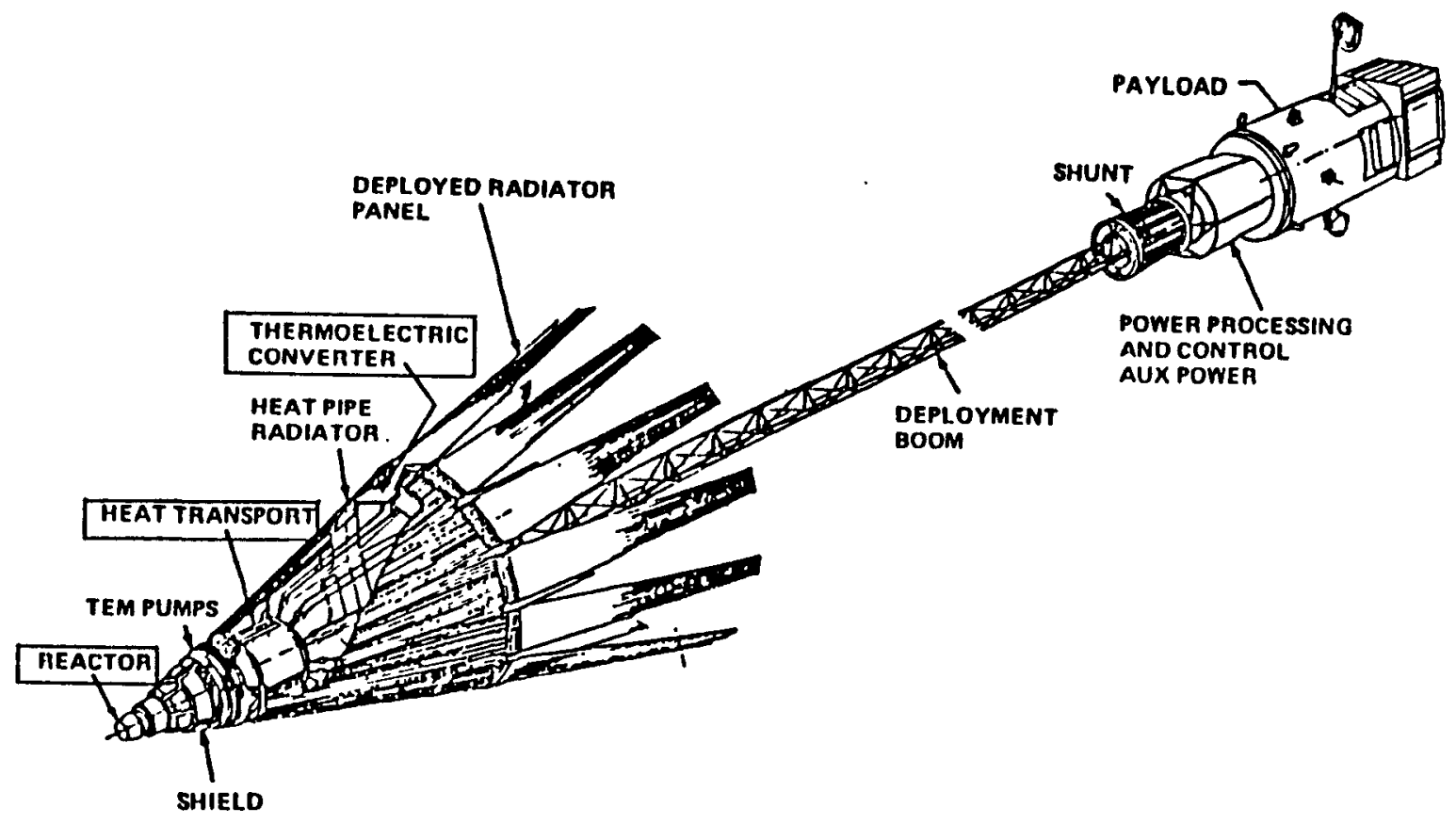

FIGURE G.2. Reactor/Thermoelectrics System.

- Long-Life Stability, Temperature Control, and Neutron Streaming of LiH Shield Material -- LiH cracking because of thermal cycling, loss of hydrogen, and reduced effectiveness.

- In-Orbit Thaw of System -- Failure of the heat pipe thaw system, solid plug left in system, and in-core thawing causing rupture of the reactor vessel and piping.

- Conductively Coupling of TE Cells with Heat Exchanger and Heat Pipes - - Not obtaining a uniform braze joint across the entire TE converter module, which could result in unacceptable temperature drops.

The reactor/thermoelectrics concept was considered to be the clear choice. The primary disadvantages of the TE system are the low power conversion efficiency ( $4 \%$ to $6 \%$ ) and the high operating temperatures. Because of the large database, the TE concept had the highest probability of meeting lifetime and reliability requirements. The TE concept also had the greatest probability of meeting both the cost and schedule constraints. Both cost and schedule were considered key decision points. The TE concept also was considered to be adequate, but not the best, to meet the growth requirement. 


\section{G.4.2.3 Reactor/Stirling/Brayton System}

The reactor/Stirling concept, with an alternative reactor/Brayton cycle concept, was developed by Rockwell International's Rocketdyne Division (see Figures G.3 and G.4). The primary advantage of either the Stirling or Brayton concepts is the high efficiency of the power conversion units. Both the Stirling or Brayton concepts used the same basic reactor technology but differed in the heat exchanger, secondary loop, and power conversion units. For Phase I, the reactor core used UN fuel in Nb-1\%Zr cladding with a tungsten liner. The maximum fuel burnup was $1.5 \%$. The reactor outlet temperature was $1150 \mathrm{~K}$ for the Stirling system and $1350 \mathrm{~K}$ for the Brayton system. The primary coolant was lithium, which was solid at launch. The primary coolant loop had three TEM pumps (only two required). Both concepts delivered 400-Vdc power to the user and were separated from the user plane by a $40-\mathrm{m}$ boom.

The Stirling system used a secondary NaK liquid loop to carry the heat to the mercury heat pipe radiator made of stainless steel with Be-Al armoring. Four superalloy opposed-piston engines were used, each capable of generating $37 \mathrm{kWe}$ (only three required). The temperature of the coolant to the engine was $1100 \mathrm{~K}$.

The Brayton system had a helium-xenon secondary gas loop to the mercury heat pipe and water heat pipe radiator. The heat pipes were fabricated from stainless steel and had copper/beryllium-aluminum armor. There were four refractory metal Brayton engines, each capable of generating $37 \mathrm{kWe}$ (only three were required to generate $100 \mathrm{kWe}$ ).

The primary concerns for the reactor/Stirling concept were:

- Thaw of Solid Lithium in Reactor and Piping -- NaK and $\mathrm{Hg}$ becomes liquid in Shuttle at launch; reactor vessel or piping can rupture during thaw; caustic material should be in double containment in shuttle bay.

- Long-1ife Engine/Heat-Exchangers/Alternator (EHA) at $1100 \mathrm{~K}$-Failure of gas bearings, thermal distortion of pressure vesse 1 causing engine or alternator seizure, loss of high-pressure $\mathrm{He}$ gas, and degradation of alternator magnetic materials under cycle stress conditions. 


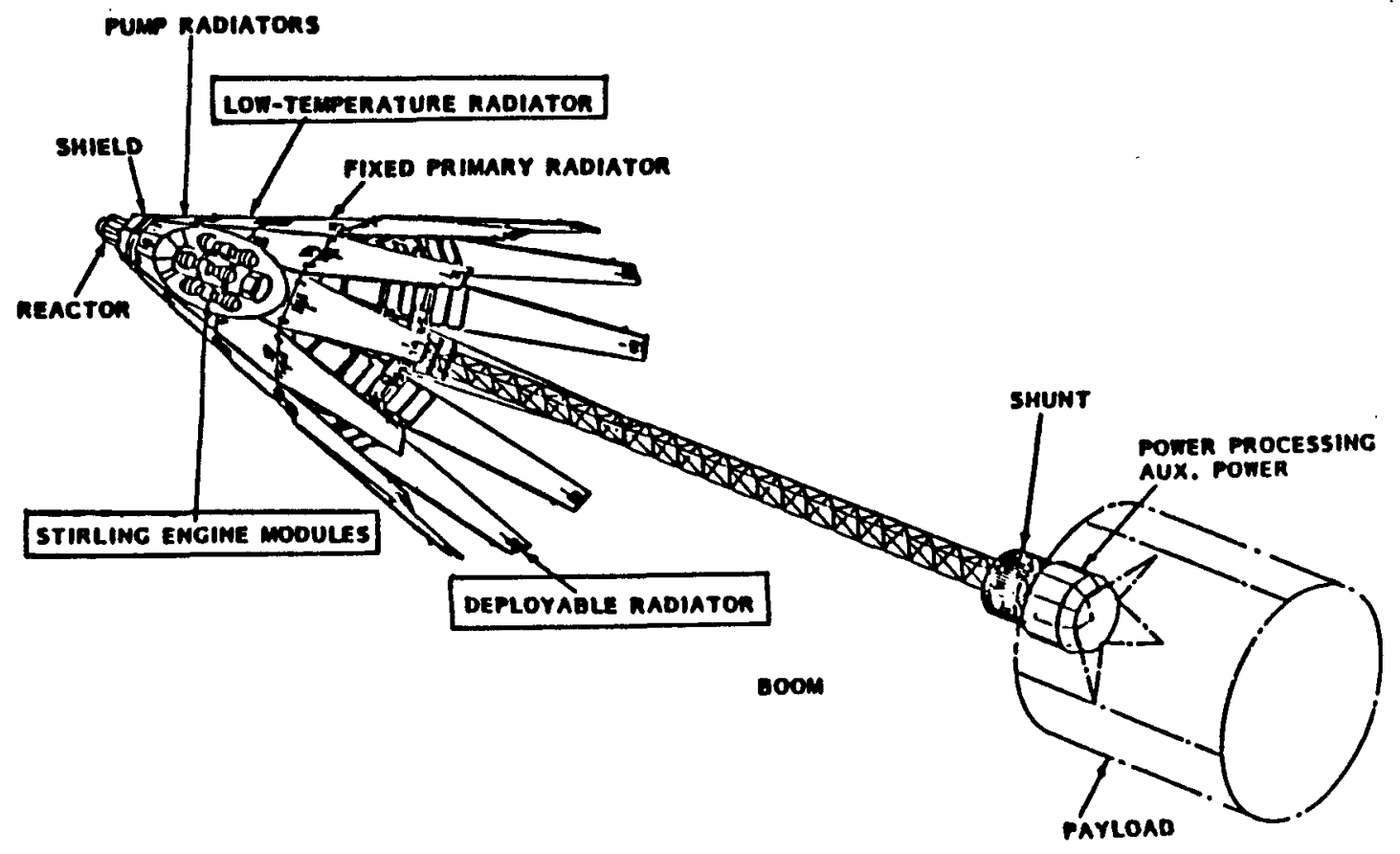

FIGURE G.3. Reactor/Stirling Cycle System.

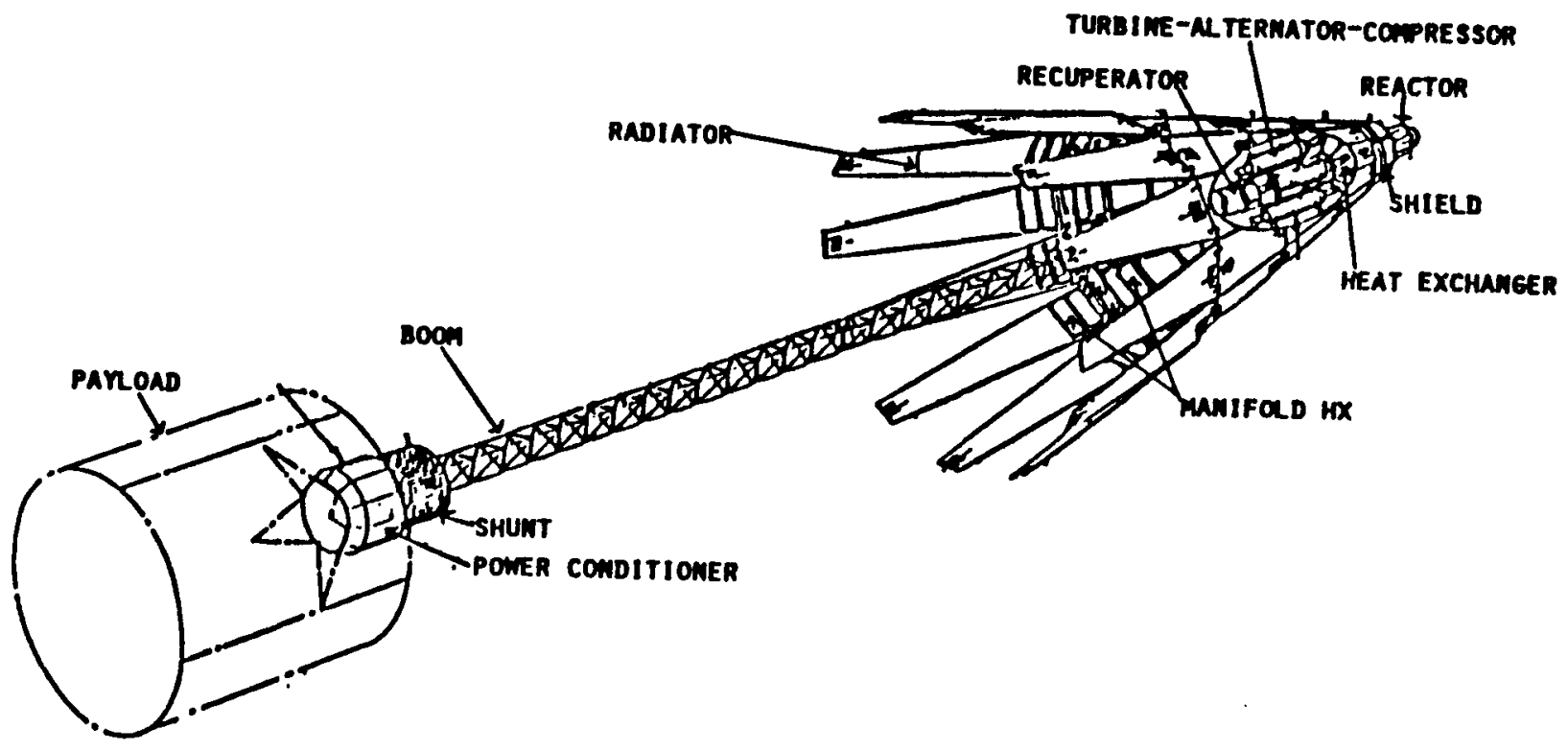

FIGURE G.4. Reactor/Brayton Cycle System. 
- Ability to Design and Fabricate EHA to Meet Predicted Efficiency, Power and Mass -- Currently EHA cannot be designed and built to meet performance specifications, and much more technology development is required.

- Refractory Metal/Inert Gas Incompatibility -- Structural material embrittlement, cracking, and pressure boundary failure.

- Lifetime Testing.

- Long-life High Power Density Mercury Heat Pipes.

Primary concerns for the Brayton concept were:

- Thaw of Solid Lithium in Reactor and Piping.

- Long-1ife Turbine/Alternator/Compressor (TAC) at $1330 \mathrm{~K}$-- First TAC is to be fabricated from refractory metal, joining of the refractor metal, and large temperature differential from turbine to compressor.

- Long-life Refractory Metal Heat Exchanger -- Single lithium leak into heat exchanger results in loss of system, or single gas leak at heat exchanger results in loss of a quarter of the systems power.

- Long-life Refractory Metal Recuperator.

- Long-life Mercury Heat Pipes and Long-life Water Heat Pipes.

- Lifetime Testing.

The Stirling concept was considered to have the highest risk in meeting the lifetime and reliability requirements, the Brayton was rated as having high risk in meeting these requirements. Both the Stirling and Brayton concepts had low probabilities of meeting cost and schedule constraints because of the required research and development. The Stirling has potential for growth and performance improvements, and the Brayton had the lowest potential of all concepts for meeting growth requirements. Both the Stirling and Brayton concepts had large mass penalities to meet the survivability requirements. This is true because of the very large radiators required due to the low reject temperatures and the long pipe runs that must be armored. 


\section{G.4.2.4 Reactor Designs}

The selection of a reactor design for each concept required consideration of the power conversion system heat source requirements, the resulting fuel and operating conditions, material compatibility, and overall system optimization. In all concepts proposed, a fast reactor design was selected in order to achieve the most compact size of reactor possible. This had a significant effect on reducing the mass of the overall power system.

A compact fast reactor requires the use of highly enriched fuel. Uranium was the clear choice of fuel from the perspectives of availability and safety. In the case of the in-core thermionic power system concept, a $\mathrm{UO}_{2}$ fueled core was proposed because of the high fuel operating temperature required by the thermionic elements. The other power system concepts, however, were able to use UN fuel because of the lower fuel operating temperatures required by the power conversion systems. The material characteristics of UN fuel (thermal conductivity and uranium atom density) allowed a highly compact reactor design.

The selection of the reactor coolant was highly dependent on the reactor fuel composition and the required coolant operating conditions. The required operating temperature for the reactor coolant in the thermionic power system concept was low enough to allow the use of Nak. The other power system concepts selected lithium as the reactor coolant because of their requirement for higher coolant temperatures and material compatibility with UN fuel. Each of these coolants has its unique advantages and disadvantages as discussed under the concept descriptions.

\section{G.4.3 System Selection}

The SP-100 System Selection Team consisted of an Executive Committee including J. Mondt (JPL), J. Scott (LANL), J. Sovie (LeRC), and Col. J. Heilman (USAF), and the technical staffs from their organizations. The evaluation was done by the SP-100 System Selection Team and staff, and a recommendation for one system concept was made to the SP-100 Project Office, which endorsed 
the recommendation and presented it for concurrence by the SP-100 Program Office. It was then presented for approval to the SP-100 Steering Committee, which was made up of J. W. Vaughan, Jr., Chairman (DOE-NE), J. Abrahamson, Lt. Gen., USAF (DOD/SDIO), and R. Colladay (NASA/OAST). The selection of the system concept was based on the evaluations of the systems against the design characteristics specified in the SP-100 System Selection Process.

The major discriminators among the concepts were 1) performance, 2) growth, and 3) cost and schedule. Within this framework, the static system concepts consistently ranked better than dynamic system concepts, but the two static systems, TI and TE, have mixed results.

The System Selection Team ranked the reactor/thermoelectrics concept as having the highest probability of meeting the performance lifetime and reliability requirements and of completing Phase II development by 1991 . The in-core thermionics system was evaluated as having the greatest potential for growth to higher power levels, but given its current level of technology readiness and the planned development schedule, it was rated as having greater risk in meeting the performance lifetime and reliability goals. This was particularly true for the TI system because it required in-core testing that could impact both the programmatic cost and schedule.

Therefore, based upon the defined discriminators and the programmatic requirements, the concept evaluation committee recommended the reactor/ thermoelectrics concept for development and testing within the SP-100 Phase II GES effort.

The Request for Proposal included specific materials and technology be included in the contractor proposal. They were specifically chosen because they could best meet the SP-100 requirements and objectives. Each material or technology was traded-off against other potential choices. The following specifications were included in the Request for Proposal for the SP-100 GES program. 
- Uranium-nitride fuel

-- high thermal conductivity/low temperature drop across the fuel

-- high uranium atom density/compact core

-- database at temperature

- compatible with lithium coolant/no adverse chemical reactions

- Niobium-based alloy

-- only commercially available refractory metal at reasonable cost

- refractory properties/high-temperature operation

-- compatible with lithium

- Lithium coolant

- frozen at launch temperatures/simplifies launch procedures

-- excellent heat capacity (took a fourth to a third less pump power for equivalent heat removal)

-- low pressure at temperature

- SiGe-GaP thermoelectric material:

-- high figure of merit (10\% to $15 \%$ higher performance over SiGe for the same $\Delta T$ ).

The power level was also set by the System Selection Committee at 300 kWe for development during the SP-100 GES. It was set at $300 \mathrm{kWe}$ to meet an AF mission in the early 1990s. Since that decision, the power level was reduced to $100 \mathrm{kWe}$ for the GES to reflect a change in power requirements for potential missions.

\section{G.5 SP-100 System Overview}

The SP-100 system design is based upon a set of key requirements. The technical requirements were established by DOE, DOD, and NASA in response to performance and functional needs that are projected by mission planners. The system is designed to generate $100 \mathrm{kWe}$ for seven years of full-power operation over a ten-year period. The SP-100 is being designed to enable launch on the shuttle within a third of the shuttle bay at the 100-kWe power level. 
The design consists of two major subsystems: The nuclear subsystem and the space subsystem. The nuclear subsystem is further broken down into four major elements: the nuclear reactor, the radiation shield, the primary heat transport, and instrumentation/control. The space subsystem consists of: the power conversion, waste heat rejection, power conditioning/control, and the support structure elements.

The SP-100 flight system will be launched with both the primary and secondary coolant in its solid rather than liquid state. Once in orbit, the reactor will be brought critical and maintained at a low power level while the lithium thaws. Once the system is thawed out, the reactor will be brought up to full power.

The reactor generates 2.4 MWt of thermal energy to produce 100 kWe for seven years of full-power operation. The SP-100 employs two coolant loops: a single primary loop that transfers heat from the reactor to the heat exchanger/power conversion unit and 12 independent secondary systems that remove the waste heat and transfer it to the potassium heat pipe radiator. Both the primary and secondary coolant is pumped by dual throat thermoelectric-electromagnetic (TEM) pumps. The thermal energy is converted directly into electricity by static thermoelectric (TE) power conversion cells. A radiation shield, located directly beneath the reactor, is used to reduce the amount of neutron and gamma radiation at the user interface. The power system is separated from the main spacecraft by a boom to reduce both radiation and thermal impact to the user. The power conditioning and control system is located near the user interface and consists of the system controller, batteries, and shunt radiator.

\section{G.5.1 The Nuclear Subsystem}

The system requirements drive the design of the nuclear subsystem or assembly (see Figure 6.5). The SP-100 nuclear reactor is designed to generate $2.4 \mathrm{MWt}$ at full power for seven years, which influences core size, enrichment zones, and burnup levels. The reactor must have two independent and diverse methods to ensure that it remains inoperable during transportation, 1aunch, and 


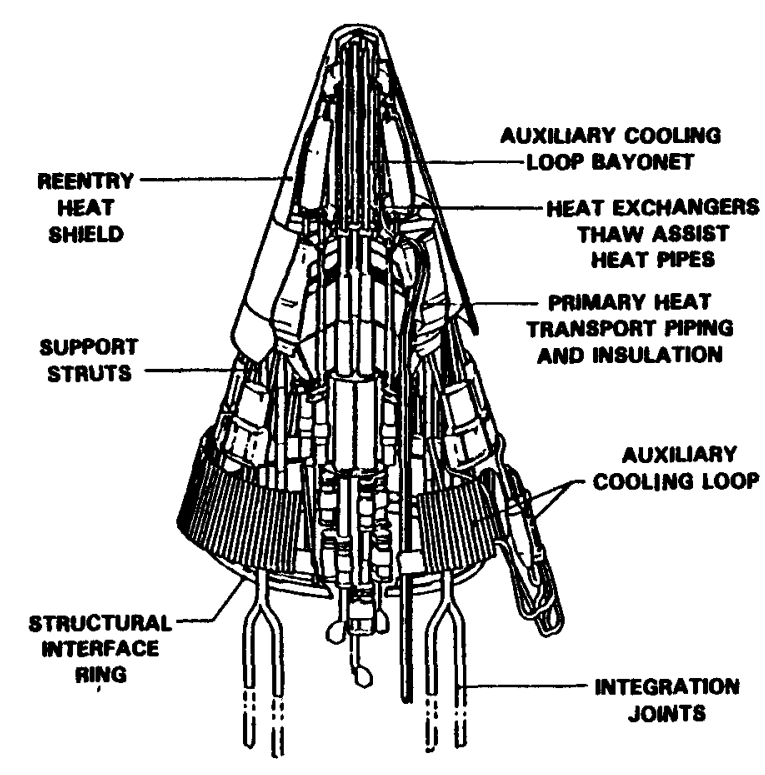

3อ11115.2

FIGURE G.5. The Nuclear Subsystem.

permanent shutdown at the end of the mission. The reactor system must have a means of removing the decay heat to ensure continued structural integrity of the system during a boost to higher orbit in the unlikely event that the reactor should experience a Loss-of-Coolant Accident (LOCA). In the case of accidental reentry, the reactor must remain intact and effectively bury itself upon impact with the earth. All of these requirements have direct effects on the design of the reactor subsystem.

The reactor core consists of 24 hexagonal-shaped assemblies with 37 fuel pins per assembly and six partial assemblies with 22 pins each. The six partial assemblies around the outer edge bring the hexagonal shape closer to a circular form. The core contains a total of 978 fuel pins plus 42 auxiliary cooling loop bayonets. The fuel pins are separated from each other and the wall of the hex assembly by wire-wrap spacers. The fuel pins have an upper plenum region to contain fission products. The fuel assemblies are encased within an integral honeycomb core structure that maintains the fuel pin spacing and helps transfer heat to the reactor vessel in the event of a LOCA. 
The SP-100 is a fast reactor with highly enriched uranium-nitride (UN). To reduce power peaking, the core has two enrichment zones, $89 \%$ and $97 \%$. The peak reactor burnup is $6 \%$. The fuel is $c 1$ ad in PWC-11 with a bonded rhenium 1 iner. The liner minimizes the fuel/cladding interaction over the reactors lifetime and reduces the reactivity effect if the core is submersed in water. Rhenium is a thermal neutron absorber. The fuel pellets are kept in position by a $W_{-}{ }^{26}$ Re spring. Insulator pellets fabricated of depleted uranium are located at both ends of the fuel stack.

The fueled region of the core is $41.5 \mathrm{~cm}$ high. The effective core diameter is $32.5 \mathrm{~cm}$. The reactor vessel outside diameter is $35.7 \mathrm{~cm}$. The fuel pellet diameter is $0.648 \mathrm{~cm}$ and the pin diameter is $0.775 \mathrm{~cm}$. The core information is based on the SP-100 Program Integration Meeting in July 1988.

The reactor has the following performance conditions for beginning-of-life/ end-of-life (BOL/EOL) operation: coolant flow rate $11.06 / 10.39 \mathrm{~kg} / \mathrm{s}$, pressure drop TBD/2.25 psi, coolant inlet temperature 1253/1289 K, and coolant outlet temperature 1305/1345 K.

Heat pipes are used to thaw the coolant in the primary coolant loop during reactor startup. The evaporator section of the sodium thaw heat pipes are in thermal contact with the reactor vessel and are conductively strapped to the hot-side ducts of the TEM pumps. The thaw heat pipes also furnish heat to the thaw cavity enclosing the secondary ducting and the power conversion assemblies.

An auxiliary coolant loop (ACL) is an integral part of the reactor design. Its function is to remove decay heat in the event of a LOCA in order to 1 imit the maximum temperature of the fuel to less than $2000 \mathrm{~K}$. Heat removal is achieved by in-core bayonet tubes that are located throughout the core. The bayonet tubes are sized to replace a single fuel pin. The ACL has its own coolant manifold at the aft end of the core. The lithium coolant is distributed from the lower chamber axially forward through the inner bayonet tubes for the full length of the fuel region of the reactor core. As the fluid reached the forward extremity of the inner bayonet tubes, it passes through slotted holes in the inner bayonet tubes. At this point, the 
lithium coolant reverses direction and flows axially aft through the core region in the annulus formed between the outer bayonet tube and the inner bayonet tube. The thermal energy is then transferred via a TEM pump to an independent $A C L$ radiator. The $A C L$ consists of a total of 42 in-core bayonet tubes. The ACL generates a total of $1.5 \mathrm{kWe}$. The design information is based on the 1988 SP-100 Nuclear Subsystem Design.

A reentry thermal protection shield is attached to the outside of the reactor vessel and the radiation shield to ensure that the reactor will withstand the aerodynamic heating of reentry and remain intact. Based on the SP-100 Program Integration Meeting in July 1988, the reentry shield is fabricated from a carbon-carbon composite and is aerodynamically shaped to ensure a predictable and stable reentry of the reactor and radiation shield.

The two independent shutdown systems on the SP-100 reactor are the internal safety rods and the external hinged reflectors. Seven in-core safety rods ensure that the reactor remains subcritical during prelaunch, launch, and postmission events. These rods are designed to be in either the ful1-in (reactor shut down) or full-out (reactor operating) position by moving ${ }_{4}{ }_{4}$ absorber rods inside structural thimbles. The safety rod thimbles extend into the upper plenum of the reactor vessel and penetrate the aft end of the reactor vessel. Be0 followers replace the $B_{4} C$ as the absorber sections are driven into the upper plenum region of the reactor vessel. A latch located inside the thimble automatically locks the in-core rods to the reactor vessel each time the rods are moved to the shutdown position. Each shutdown rod takes up the equivalent area of a single fuel assembly. The 12 reflector control elements are used to bring the reactor critical after all of the in-core absorber rods are withdrawn, and to control the reactor over the seven-year lifetime by compensating for fuel burnup and swelling. The reflector elements achieve reactor control by moving the beryllium reflector elements toward or away from the reactor vessel, thereby controlling neutron leakage from the core. The reflector segments are fabricated from BeO and contained within a $\mathrm{Nb}-1 \% \mathrm{Zr}$ she 11 . 
The in-core rods and hinged reflectors are driven into position by actuators located at the aft end of the shield. The hinged reflectors have single actuators per each reflector segment. The reactor will continue at full power with the loss of a single drive function in up to one nonadjacent drive. Two independent actuators are provided for each in-core safety rod. A safety rod is moved out of the core against an extension spring force by advancing the ball screw with the stepper motor. The stored energy of the spring combined with the fail-safe action of the clutch in the actuator provides a highly reliable automatic shutdown function. The position of the in-core safety rods is determined by the use of limit switches. The position of the reflector control segments is measured by use of a shaft position encode. The design information is based on the 1988 SP-100 Nuclear Subsystem Design.

The radiation shield is located directly aft of the reactor. The purpose of the shield is to reduce the level of gamma and neutron radiation at the user plane to an acceptable level and to protect the power system components and instrumentation. The user $\mathrm{plane}$ is assumed to be a $4.5-\mathrm{m}$ disc at a separation distance of 22.5-m from the center of the reactor core. The shield must reduce the radiation to the user plane to $10 E+13 \mathrm{n} / \mathrm{cm}^{2}$ ( $1 \mathrm{MeV}$ equivalent) and $5 \times 10 E+5$ rads ( $\mathrm{Si}$ ). The power system is maintained with a $17^{\circ}$ half-cone angle to help minimize the overall mass of the shield. The bottom of the reactor vessel is bolted to the top of the shield assembly. The shield is fabricated from LiH pressed into a stainless-steel honeycomb to attenuate neutrons. Tungsten plates are used primarily to attenuate gamma radiation, beryllium is used to transfer heat to the outer surface of the shield, and titanium is used to contain the shield.

The primary coolant loop consists of six inlet and six outlet loops symmetrically located around the bottom of the reactor vessel. The coolant enters the reactor at the bottom of the core and passes through the coolant passage between the honeycomb structure and the reactor vessel to an upper plenum. The coolant is then directed into the core where heat is removed. 
Upon leaving the reactor core, the coolant enters the gas separator/ accumulator. The purpose of the gas separator accumulator is to remove the small amount of He generated within the lithium coolant as a results of the neutron interaction with coolant and to accommodate thermal expansions and contractions of the lithium. After the coolant leaves the gas separator/ accumulator, it is divided into two flow paths each going to a separate TEM pump.

The TEM pumps circulate the liquid lithium in both the primary and secondary side heat transport loops. On the primary side, the coolant passes through the TEM pump twice. The TEM pumps are self-energized, dc conduction, electromagnetic pumps. They use thermoelectric materials to internally generate the electric power needed for them to operate. A single EM pump unit has a dual-throat to circulate both primary and secondary coolant. The temperature drop required to produce electricity with in the thermoelectric elements is provided by the temperature difference between the primary and secondary coolant loops. The coolant is circulated to the heat exchanger/ power conversion unit and then back to a single loop before reentering the core. The TEM pump inherently varies the flow rate as a function of the system operating temperature.

Sensors provided to monitor the nuclear subsystems performance include pressure gauges, flow monitors, and temperature sensors. Diversity as well as redundancy are used for critical control signals, such as temperature and control element position. The reactor controller uses diagnostic and fault detection logic to allow operation with failed sensors. Many of the sensors are in areas where unclear radiation, thermal gradients, and vacuum environments are severe. The reactor controller, which monitors the sensors information and controls the reactor, is located at the payload end of the boom over $20 \mathrm{~m}$ away from the origin of the reactor information. The sensor signals (some in the millivolt range) must transmit along with other signals along the boom to this signal conditioning equipment. To enhance the signal, while minimizing the volume and weight of the cabling, an analog multiplexer/ amplifier is used. The multiplexers are located aft of the shield. 


\section{G.5.2 Space Subsystems}

The space subsystem is divided into 12 independent power conversion loops (see Figures G.6 and G.7). The system is designed so that 11 of the 12 loops can generate the full $100 \mathrm{kWe}$. The radiator panels are launched in a stowed configuration with the lithium coolant in a solid state. According to the SP-100 GES Project Annual Technical Progress Report for 10/86 - 9/87 (CDRL M028), the deployable radiator assembly is configured to permit a compact nesting of the panels in the launch position by overlapping six inner panels with six outer panels to minimize the radial dimension of the stowed configuration. The flexible joints between the fixed radiator panels and the deployable radiator panels are void of lithium prior to reactor startup. The radiator panels are deployed before the system is thawed to ensure a uniform thaw front.

Waste heat from the power conversion assembly and TEM pumps is transferred by the secondary coolant loops to the radiator assembly and rejected to space. A Ti/Be cold-side heat exchanger serves to transfer the waste heat from the power conversion subsystem to the lithium coolant of the heat rejection subsystem. The secondary coolant is circulated by the dual-throat TEM pumps to the radiator assembly through Ti piping. The lithium flows through the fixed radiator panel ducting, through the flexible joint and down the deployed radiator panel supply duct. The supply duct then transitions to the return duct. The lithium flows back to the TEM pump while transferring its heat through the $\mathrm{Ti} / \mathrm{Be}$ ducting into the $\mathrm{Ti} / \mathrm{Be}$ heat pipes. The heat pipes have titanium foil wicks that distribute the heat along the radiator where it is rejected to space. The heat pipes are attached to both the supply and the return ducts. Bleed holes between the supply and return ducts provide a circulation path for the lithium as it thaws during reactor startup. A11 the exposed heat pipes and lithium ducting have armor to provide protection from micrometeroid penetration. (See Section G.5.2.)

The coolant is circulated by a TEM pump to the power conversion assembly ( $P C A)$ /heat exchanger. Each PCA is made up of Thermoelectric Converter Assemblies (TCA) mounted in a common structural support frame and joined by 


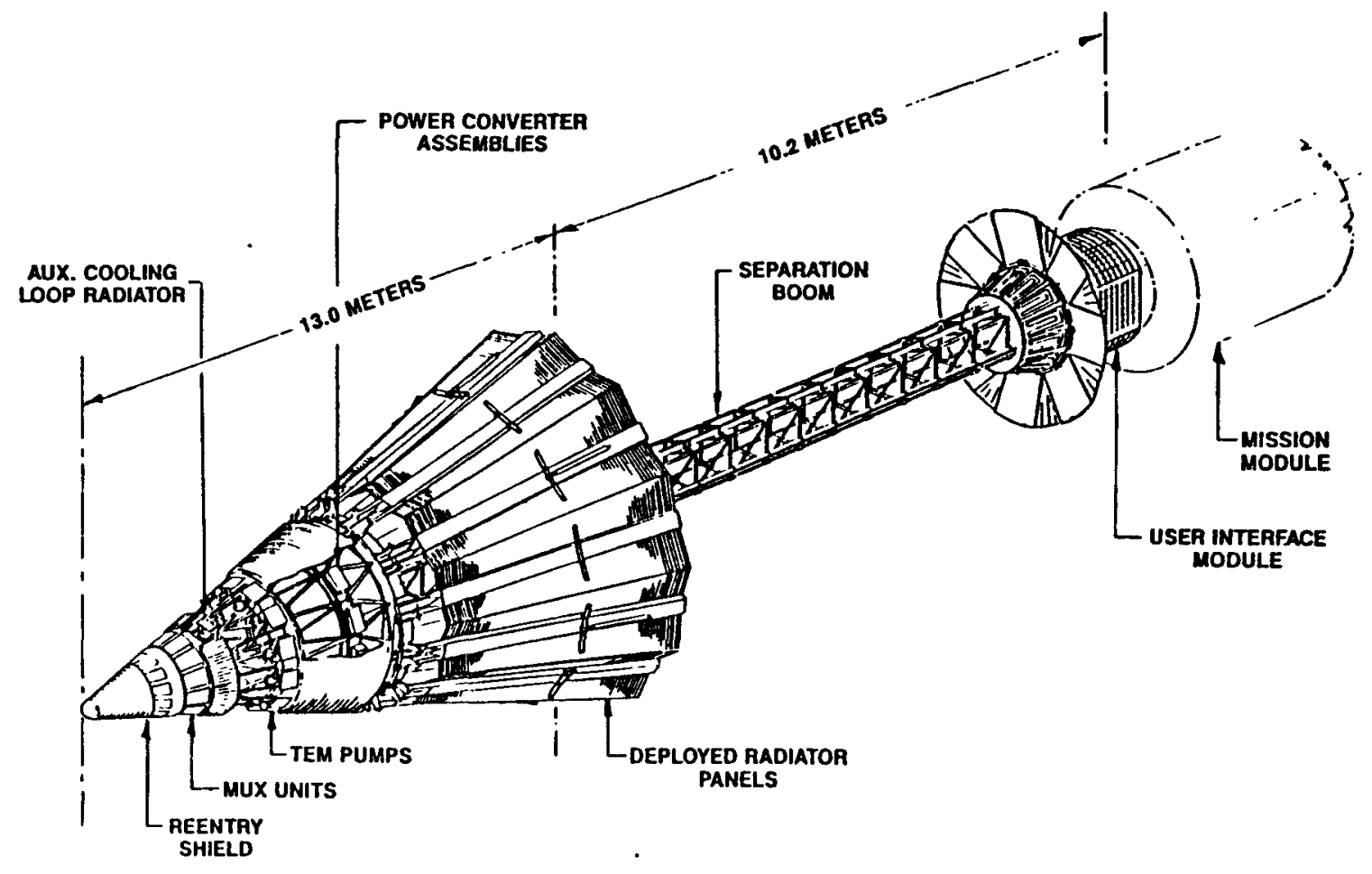

FIGURE G.6. Space Subsystem in Deployed Configuration.

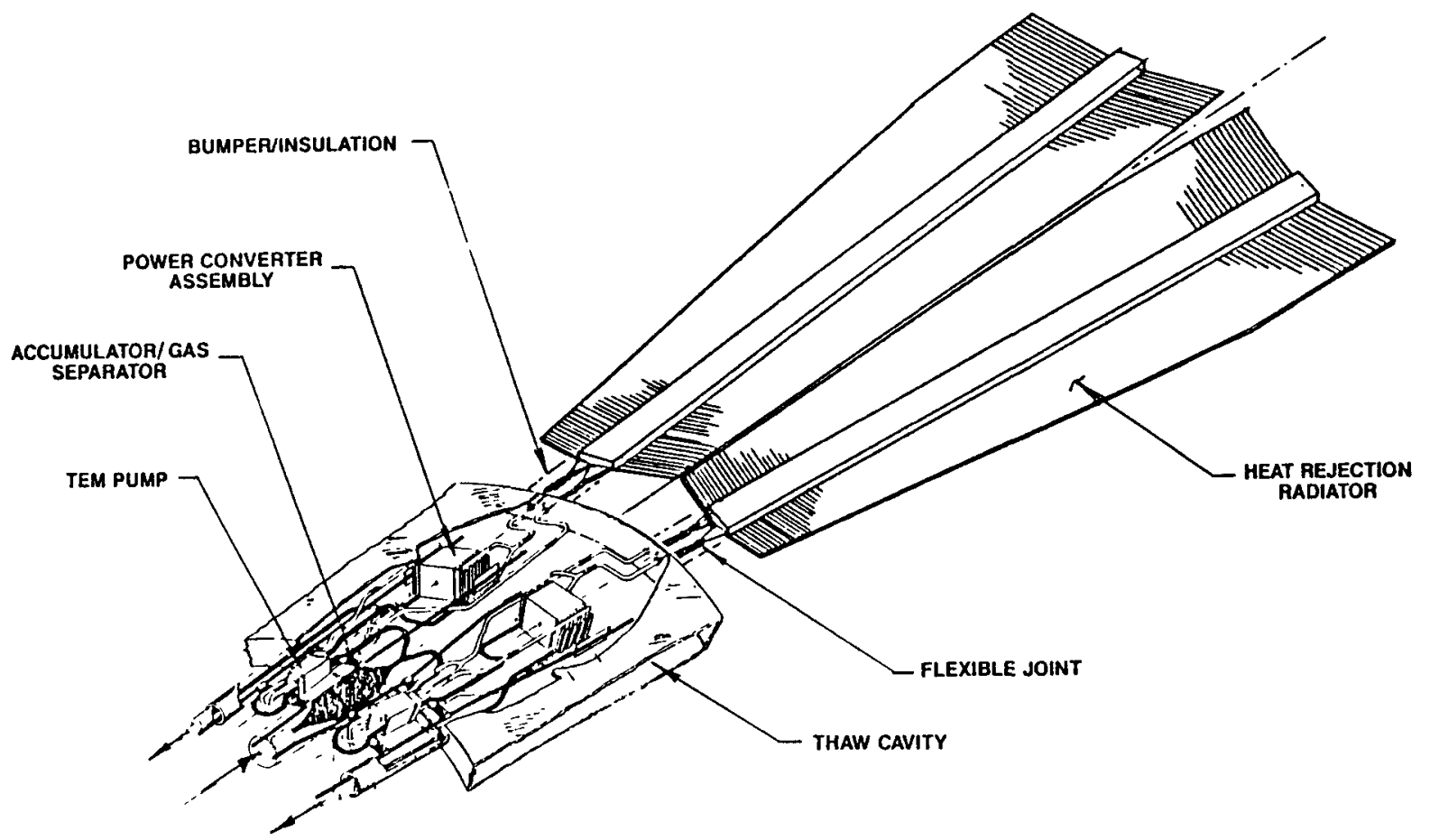

FIGURE G.7. Typical Segment of Energy Conversion Assembly. 
tubing manifolds that permit parallel flow of fluid through each of the six sets of heat exchangers. Each TCA consists of a layered assembly of one hot-side heat exchanger and two cold-side heat exchangers with arrays of thermoelectric cells between hot and cold heat exchangers. Each TCA has two arrays of cells called thermopiles. Counter fluid flow occurs through matching hot and cold heat exchangers so that all thermoelectric cells are subjected to approximately the same temperature gradient. The 60 thermoelectric cells within each thermopile are electrically connected with two rows of cells in parallel and 30 cells in series. The design information is based on the SP-100 Program Integration Meeting in July 1988. Thermopiles are further connected in series to provide the required voltage and power at the interface with the power conditioning, control, and distribution subsystem.

Each thermoelectric cell, consisting of a thermoelectric module, compliant pads and electrical insulators, is conductively bonded between hot and cold heat exchangers. The electrical insulators are bonded directly to the heat exchangers on each side and isolate the cell from ground, while the compliant pads on each side permit differences in thermal expansion and thermal distortions to be accommodated. The thermoelectric module includes 32 couples of $n$-type and $p$-type materials. Couples are interconnected within the module by electrodes, with four couples in parallel and eight in series. The thermoelectric cell is the smallest power-producing component and is the basic building block of the power-conversion subsystem.

The PCA is supported within a Be support frame that pins the hot- and coldside heat exchangers together at a central location and that supports the connecting manifolds. In CDRL M028, all externally applied thermal deformations are resisted by the support frame, while deformations within a TCA assembly are accommodated by the compliant pads (see Section G.5.2).

Each of the 12 radiator assemblies are constructed of an array of varying length of potassium heat pipes brazed to a lithium duct/strongback structure at the center. The physical one-sided area of the radiator is $106.4 \mathrm{~m}^{2}$. The center spine carries adjacent lithium supply and return ducts that function to transfer heat to the attached heat pipe evaporator sections. The Be 
also functions as a strongback providing structural integrity for the pane 1 in its launch stowed configuration and as a bumper to protect the ducting from puncture due to micrometeroids or space debris (For this and following paragraphs, see CDRL M028, Section G.5.2).

The radiator heat pipe is a "D"-shaped co-extruded Ti/Be tube that encapsulates the titanium foil wick and potassium working fluid. The foil wick provides good capillary action and the Ti/Be tube provides a good conductive medium from the inside of the pipe to the high emissivity coated surface for radiation to space.

Each radiator panel has two flexible joints for the supply and return duct. The joints will be void of lithium in the frozen state so that the radiator can be deployed prior to the reactor startup. Accumulators are provided within the heat rejection subsystem to accommodate the variable volume necessary to compensate for expansion and contraction of the lithium coolant. The accumulators will be fabricated from titanium.

The power conditioning, control, and distribution (PCC\&D) subsystem provides main bus regulated power and secondary bus power to the user plane electrical interfaces. It also provides command and control of the power system, and transmits status and telemetry to the user. A modular shunt voltage regu1 ator controls the main bus voltage by maintaining the electrical load on the thermoelectric converters at the design point with a controlled resistive load. The shunted power is radiated to space by a high-temperature dissipator. The modular design allows reconfiguration of the shunt regulators and bus control unit in response to mission changes and any degradation in orbit.

The mechanical/structural subsystem provides mechanical and structural integration of components as well as maintaining thermal control. The primary structure for the power system consists of a series of structural rings interconnected with support trusses. To meet stiffness requirements, bery1lium is used for the tube material and Ti/SiC metal matrix is used in highly stressed areas. The truss tube members are configured with standard lug/ clevis fittings. The mechanical system is required to retain deployables 
such as the boom, user interface module, and radiator during launch. It must then deploy the boom and radiator upon command while establishing in-orbit configuration and maintain correct spacecraft mechanical configuration for all mission phases. Thermal control is required to maintain thaw cavity integrity using multilayer insulation and to maintain electronics at standard temperatures. 


$$
\text { A P PENDIX H }
$$

ENVIRONMENTAL CONSEQUENCES OF A SEVERE (BEYOND DESIGN BASIS)

REACTOR ACCIDENT AT THE SP-100 TEST SITE 
Blank Page 
ENVIRONMENTAL CONSEQUENCES OF A SEVERE (BEYOND DESIGN BASIS) REACTOR ACCIDENT AT THE SP-100 TEST SITE

H.1 INTRODUCTION

In order to provide a perspective of the bounding environmental consequence associated with the SP-100 GES Test Site reactor test, an accident scenario is developed in this appendix that goes beyond the Design Basis Accidents. This severe reactor accident represents an extreme scenario that postulates gross degradation of engineered safety features and takes no credit for short-term emergency response actions. This scenario is included in this Environmental Assessment to provide a discussion of a very low probability (virtually incredible) type of occurrence.

The discussion in this appendix is made up of several separate presentations on related topics that indicate a severe accident will not occur. This approach attempts to place in perspective the bounding consequences associated with severe accidents of sufficiently low probability of occurrence that they are not included in the design basis. Detailed probabilistic data for equipment failure, etc., from which accident likelihood could be deve1oped are not available at this stage of the project design; however, this sequence of events will be extremely unlikely, based on design and operations measures taken.

\section{H.2 OVERVIEW OF ACCIDENT SEQUENCE CONSIDERED}

An accident sequence was developed that took credit only for passive systems (i.e., systems that do not require power or automatic actions during the event). Further, although operator action could terminate or mitigate the event at many points during the sequence, operator action was presumed to be unavailable or ineffective during that portion of the transient when it could have a significant impact. 
The initiating postulated event for this discussion is a severe break in the primary loop [Loss-of-Cooling Accident (LOCA)], resulting in loss of the Main Heat Transport System (MHTS) cooling for the reactor core while operating at power. This is unlikely because the MHTS materials are highly ductile at operating temperatures and, should they fail, would tend to fail by an initial small leak that would be detectable in time to allow safe shutdown.

The accident is postulated to progress by failure of the Auxiliary Cooling System (ACS), which would normally provide for adequate backup decay heat removal following a loss of coolant from the MHTS. The ACS uses independent piping and components, so concurrent failure is unlikely. Further, the ACS decay heat removal system is diverse in its secondary cooling system design so that it will not be subject to common mode failures (i.e., failures of similar components because of a common flaw).

The likely result of this total failure of decay heat removal would be collection of the leaked lithium and other materials in the guard vessel portion of the vacuum vessel. The guard vessel would conduct the decay heat away, and the event would terminate without fission product release or environmental consequence.

For this severe accident scenario, the progression without cooling is presumed to result in core melt, followed by recriticality. The energy release from the postulated recriticality is computed by the conservative Bethe-Taite methodology. This energy is converted into work, and the vacuum vessel damage is evaluated. Significant internal damage is done to systems within the vacuum vessel; however, the vessel does not fail. Although the vacuum vessel is expected to withstand extreme transients, a $6.45 \times 10^{-4} \mathrm{~m}^{2}$ $\left(1-i n^{2}\right)$ equivalent breach is assumed (resulting from seal penetration or similar failure). The fuel is assumed to be dispersed in a coolable noncritical geometry.

A breach of the vacuum vessel would normally be insignificant because the vacuum vessel would have been inerted with helium upon any degradation of the vacuum such as would result from a lithium leak. However, operator 
inaction or unspecified system problems are postulated to result in no vacuum vessel inerting. This results in air in-leakage and ignition of the lithium metal in the vacuum vessel. The fire is postulated to continue until the lithium is consumed.

The fission product noble gas and halogen inventory is available for release upon failure of the vacuum vessel boundary. The volatile fission products are released as a result of the lithium fire. The fission products and combustion products pass into the reactor cavity and test cell (the areas around the vacuum vessel). The reactor cavity and test cell would be slightly pressurized by the release from the vacuum vessel. The pressure will result in outleakage into the main containment vessel.

The containment vessel will be designed to isolate upon detection of high radiation, following standard reactor containment design practice. Further, the isolation valves can be manually closed by the operators to preclude release. Pressures developed as a result of either lithium or sodium fires will not exceed $35 \%$ of the containment design pressure. Hydrogen explosions are improbable because of the stoichiometric limit on the quantity of hydrogen that can be generated. No credible accident progression is expected to challenge containment. For the purposes of developing a severe accident, the two containment isolation valves installed in series on the heating and ventilation exhaust penetration are postulated to fail open. This would result in a $0.61-\mathrm{m}\left(24-\right.$ in. $_{\text {) }}$ diameter hole in containment.

The leakage would pass through installed roughing filters and through HEPA filters that would result in a substantial reduction in aerosols. Noble gases would be released at a rate controlled by the pressurization of containment resulting from the lithium fire and decay heat; no mitigation would be expected.

\section{H.3 EVALUATION METHODOLOGY}

Detailed discussions of the methodology for this analysis are available in Sections H.6 through H.18. 
The evaluations presented in this appendix include a mixture of nominal and conservative evaluations with the goal of providing bounding consequences. Where possible, nominal analyses were used to allow realistic consequence assessments. When specific data were not readily available, conservative projections were made. This will result in some exaggeration of the consequences, but it is consistent with the goal of providing bounding consequences.

Residual conservative assumptions can be expected to result in still lower consequences as this analysis is further refined. As an example, no depletion of either oxygen or nitrogen was assumed during the burn. If it were included in a refined model, the rate of release of fission products would be decreased. No credit was taken for fallout within containment of particulate material; this phenomenon would reduce the dose commitment to the site boundary individual. Another example of such an assumption is the use of 95\% (worstcase) meteorology for the severe accident analysis; as a consequence of nominal meteorology alone, the average dose to an individual at the site boundary can be expected to be 7 to 12 times lower than this prediction.

\section{H.4 SUMMARY OF RESULTS AND PERSPECTIVE}

For the offsite (public) individual the maximum whole-body dose from noble gases and iodine is 0.75 rem. This amounts to a single exposure dose for that individual of 7.5 times that of the annual natural background dose of $100 \mathrm{mrem}$; no acute health effects would result.

Latent cancer fatalities per accident resulting from the whole-body dose, based on the conservative linear dose response model (see Appendix A), can be bounded. For a release into the sector with the largest and closest population, the total offsite (public) population whole-body dose would be less than 6 person-rem. Applying the conservative linear dose response model (see Appendix $A$ ), this implies that less than $6 \times 10^{-3}$ latent cancer fatalities would result if this low probability accident were to occur. 
Onsite (worker) doses, projected at $100 \mathrm{~m}$ from the facility, would not exceed 3.4 rem for the whole body. Because of facility radiation monitoring capability, evacuation plans and drills, awareness, related radiation work training and related considerations, actual doses would be expected to be lower. No acute effects result from exposures at this level; there would be no immediate fatalities. 


\section{LITHIUM FIRE ANALYSIS}

R. Van Vleet, August 12, 1988

\section{H.6 INTRODUCTION}

The postulated initiating event for this discussion is a severe Loss-ofCooling Accident (LOCA) resulting in loss of the Main Heat Transport System (MHTS) cooling for the reactor core. Additionally, the Auxiliary Cooling System (ACS) is assumed to fail concurrently. It is assumed that the result of this total failure of decay heat removal would lead to a core melt with subsequent recriticality. The energy release from the postulated recriticality is converted to work. Significant internal damage is done to the internal systems; however, the vacuum vessel does not fail on a massive scale. An equivalent breach of $6.45 \times 10^{-4} \mathrm{~m}^{2}\left(1 \mathrm{in}^{2}\right)$ is assumed.

Upon loss of coolant, the entire core inventory of $350 \mathrm{~kg}(7721 \mathrm{bm})$ of uranium $(\mathrm{H} . \mathrm{l})$ is assumed to homogeneously mix with the entire inventory of $450 \mathrm{~kg}(990.67 \mathrm{lbm})$ of lithium and uniformly deposited in a layer in the cone of the vacuum vessel. Figure H.l illustrates the currently anticipated design of the vacuum vessel.

The initial temperature of the lithium-uranium mixture is assumed to be the melting point of pure uranium, i.e., $1405 \mathrm{~K}\left(2529^{\circ} \mathrm{R}\right)$. The vacuum vessel is initially assumed to contain air at $101.3 \mathrm{kPa}(14.7 \mathrm{psia})$ at a temperature of $333 \mathrm{~K}\left(600^{\circ} \mathrm{R}\right)$ and the ambient temperature outside the reactor cell is assumed to be $294 \mathrm{~K}\left(529^{\circ} \mathrm{R}\right)$.

\section{H.7 LITFIRE ANALYSES}

LITFIRE ${ }^{(H .1)}$ is a computer code developed at the Massachusetts Institute of Technology to predict the consequences of a postulated lithium spill in a fusion reactor containiment. The code was specifically formulated to find the pressure and temperature profiles in an idealized geometry. In order to follow the containment response, LITFIRE solves a set of coupled equations 


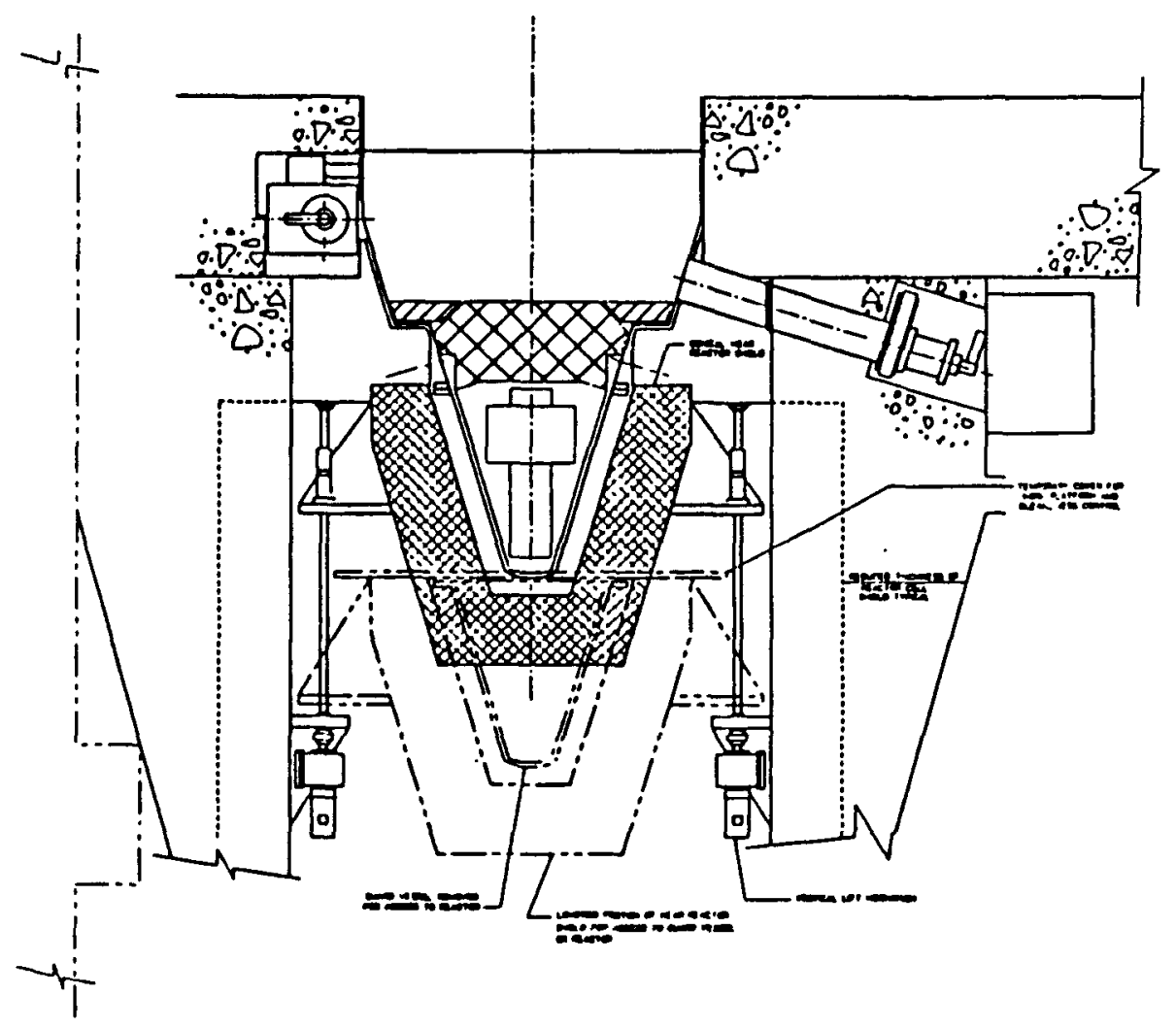

FIGURE H.1. Water Shield Reactor Cell Configuration.

that describe the simultaneous processes of heat and mass transfer. It uses well-known methods of finite differences for the spatial dimensions, and either Simpson's rule or a fourth-order Runge-Kutta method in the time domain. The code has been verified using a series of small-scale lithium experiments performed at the Large Sodium Fire Facility (H.2) operated by Westinghouse Hanford Company.

The event was analyzed using the LITFIRE computer code with a two-cell option. Figure H.2 shows a schematic representation of the two-cell geometry. In this configuration, the primary cell, i.e., the vacuum vessel, is modeled as a steel shell. The secondary cell was originally modeled as the reactor cell; however, the lithium did not fully react since the vacuum vessel and the reactor cell do not contain enough nitrogen and oxygen to 


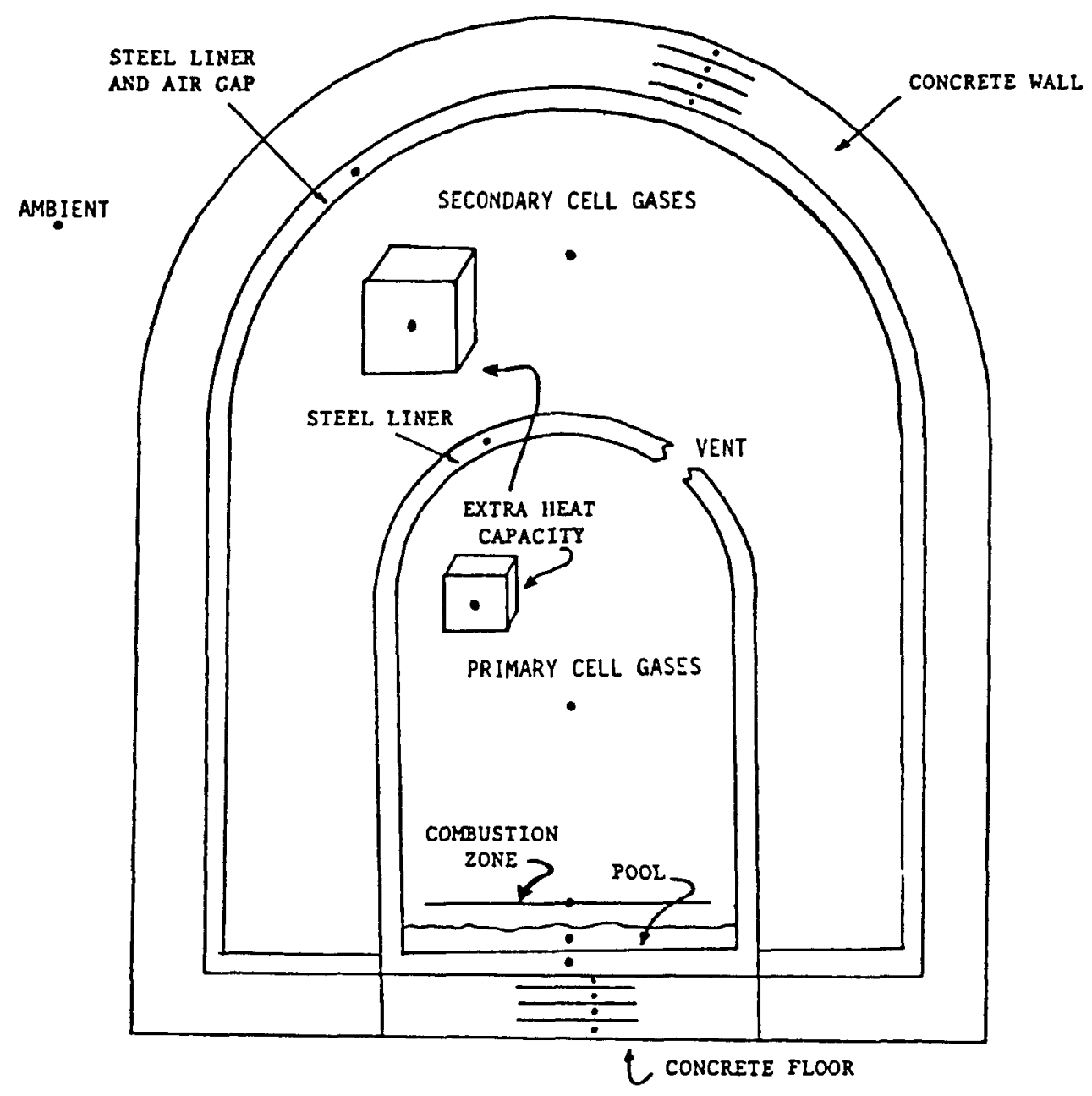

FIGURE H.2. Geometry for a Two-Ce11 LITFIRE Run.

complete the combustion process. Additionally, since the reactor cell is connected to the main containment building via a vent or crack, the secondary cell was modeled to have the attributes of the main containment building.

The LITFIRE analyses were carried out to correspond to $20,000 \mathrm{~s}$ of real time. The pertinent results from these analyses were the volumetric heat generation rate due to chemical reactions between nitrogen and oxygen, the volumetric heat generation rate due to the decay heat, and the total 
volumetric heat generation rate. The heat generation rate due to chemical reactions ends at $\sim 16,000 \mathrm{~s}$ (the combustion of the lithium is completed) and thereafter only the heat generation rate due to decay heat is considered. The time-varying total heat generation rate was supplied as input to the computer code CONTAIN.

\section{H.8 REFERENCES}

H.l D. S. Barnett, E. Yachimiak, V. Gilberti, and M. S. Tillack, LITFIRE User's Guide, PFC/RR-87-11, Massachusetts Institute of Technology, PTasma Fusion Center, Cambridge, MA, August 1987.

H.2 D. W. Jeppson, Scoping Studies -- Behavior and Control of Lithium and Lithium Aerosols, HEDL-TME 80-79, Hanford Engineering Development Laboratory, Richland, WA, January 1982. 


\section{CONTAIN CODE ANALYSIS OF RADIONUCLIDE RELEASE RATES}

TO THE ENVIRONMENT FROM THE GES TEST SITE BDBA

M. Kummerer, August 12, 1988

H.9

INTRODUCTION

Analysis of the mass and energy transport through the containment system and the subsequent release of radionuclides to the environment was performed using the CONTAIN computer code. The combined heat generation rate from the lithium chemical reactions and the decay heat, calculated using the LITFIRE code, was applied as a volumetric heat source to the mixed lithium-uranium pool on the vacuum vessel floor. Radioactive noble gas and iodine species were released into the vacuum vessel over the first two minutes of the analysis.

H. 10 CONTAIN CODE DESCRIPTION

The CONTAIN $(\mathrm{H} .3)$ computer code is an analysis tool for predicting the conditions inside containment and connected buildings following a severe reactor accident. The primary advantage of CONTAIN is that it takes account of the strong dependence between the important physical processes that govern the response of the system to accident conditions. Its treatment of the feedback loops between thermal-hydraulic behavior and aerosol and fission product transport provides a mechanistic approach to the analysis.

The code was developed at Sandia National Laboratories for the Nuclear Regulatory Commission (NRC). The first documented version of the code was released in 1984. Successive improvements have been made in response to the changing base of technical knowledge about reactor accident phenomena. CONTAIN has been involved in numerous validation exercises conducted in the United States and other countries. The current documented and validated version of the code is CONTAIN 1.1.

CONTAIN provides the capability for modeling a wide range of the phenomena associated with severe reactor accidents. Among these are options that include the effects of core-concrete interactions, hydrogen and carbon 
monoxide combustion, sodium reactions for liquid metal reactors, and aerosol behavior. In addition, a large variety of engineered safety systems can be simulated.

Since the current version of the code does not include an option for modeling lithium chemistry, only the options that are independent of reactor type were used in this analysis. These include models for calculating the thermodynamic state of the atmosphere in each defined volume, intercell flow options, and fission product behavior.

Several choices are available for the calculation of flows between volumes. In this analysis, an inertial flow option using an implicit flow solver was selected.

\section{H.11 DESCRIPTION OF THE MODEL}

\section{H.11.1 Physical Arrangement}

The model of the SP-100 Ground Engineering System Test Site that was prepared for input to the CONTAIN code consists of four volumes, arranged as shown in Figure H.3. The vacuum vessel is represented as a stainless steel cylinder equivalent in volume, $37.05 \mathrm{~m}^{3}\left(1308.5 \mathrm{ft}^{3}\right)$, and surface area, $67.4 \mathrm{~m}^{2}$ $\left(725.8 \mathrm{ft}^{2}\right)$ to the actual vessel, and with a wall thickness of $1.3 \mathrm{x}$ $10^{-2} \mathrm{~m}(0.5 \mathrm{in.})$.

This volume is enclosed within the reactor cavity, represented as a rectangular room with a volume of $276.4 \mathrm{~m}^{3}\left(9760 \mathrm{ft}^{3}\right)$ and concrete walls $0.91 \mathrm{~m}$ $(3 \mathrm{ft})$ thick. The inside of the volume is lined with a $1.3 \times 10^{-2} \mathrm{~m}$ (0.5 in.) thickness of steel.

The third volume, surrounding the reactor cavity, is a cylindrical structure representing the lower portion of the containment building. Its volume, $4668 \mathrm{~m}^{3}\left(16,500 \mathrm{ft}^{3}\right)$, represents $\sim 43 \%$ of the total volume of the building. The walls are modeled as $1.3 \times 10^{-2} \mathrm{~m}(0.5 \mathrm{in}$.$) thick steel.$ 


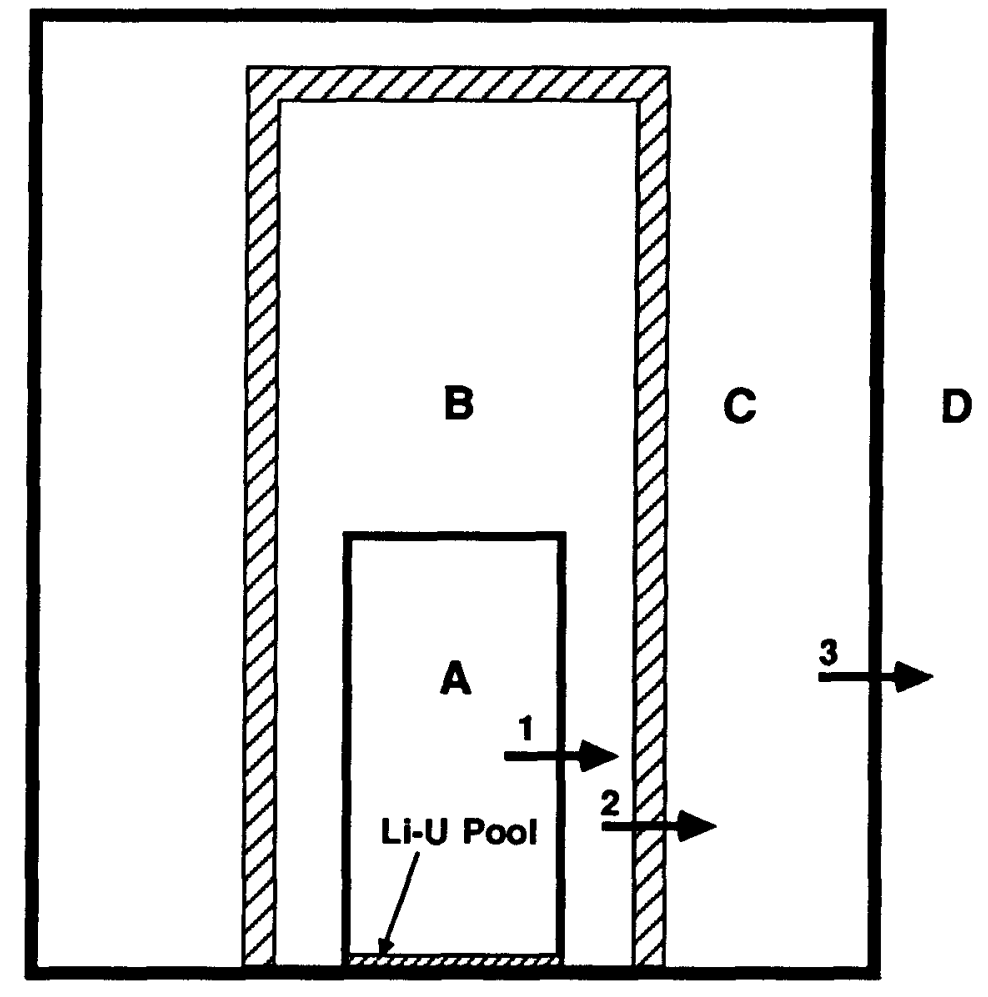

Cells

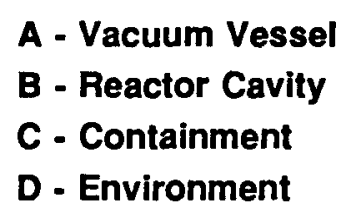

Flow Paths

$$
\begin{aligned}
& 1-1 \mathrm{in}^{2} \\
& 2-50 \mathrm{in}^{2} \\
& 3-3.12 \mathrm{ft}^{2} \\
& \quad 38808115.1 \mathrm{~m}
\end{aligned}
$$

FIGURE H.3. SP-100 GES Test Site CONTAIN Model Schematic.

In order to track the flow of gases and their associated radionuclides to the outside, the model includes a fourth very large volume that represents the environment.

\section{H.11.2 Flow Paths}

Flow paths for the passage of gases between the volumes of the model were chosen to be consistent with the accident scenario as described. The postulated breach in the vacuum vessel is modeled as a $6.45 \times 10^{-4} \mathrm{~m}^{2}$ $\left(1 \mathrm{in}^{2}\right)$ opening between the vacuum vessel and the reactor cavity. Leakage 
from the cavity into containment is modeled by a single flow path with a cross-sectional area of $3.12 \times 10^{-2} \mathrm{~m}^{2}\left(5.0 \mathrm{in}^{2}\right)$. Communication between containment and the outside through the two failed valves is represented as a single $2.9 \times 10^{-1} \mathrm{~m}^{2}\left(3.12-\mathrm{ft}^{2}\right)$ opening.

\section{H.11.3 Heat Source}

As the accident scenario prescribes, a pool of molten core mixed with leaked lithium coolant accumulates at the bottom of the unfailed vacuum vessel. The LITFIRE code was used to analyze the progress of the exothermic reaction of the lithium with the available oxygen and nitrogen in the atmosphere. These heats of reaction, combined with the decay heat and expressed as functions of time, were applied as a volumetric heat source to the liquid pool in the CONTAIN model. Figure H.4 shows this heat source as a function of time. Subsequent heat transfer between the pool and the atmosphere gases occurs by conductive and convective mechanisms. Radiative transfer between the pool and the vessel walls is also modeled.

\section{H.11.4 Fission Product Source}

The fission product source term used for the analysis is the same as that used for the site suitability dose consequence calculation for the GES Test Site. To simplify the analysis, tracking of fission products through containment and into the environment was limited to the dominant dose contributors, i.e., the noble gas and iodine species.

Total core inventories for the radionuclides of interest were based on a RIBD $^{(H .4)}$ calculation for an 8-MW version of the SP-100. (H.5) The 8-MW inventories were multiplied by a factor of 0.3125 (2.5 divided by 8 ) to obtain approximate inventories for the 2.5-MW reactor.

It was assumed that, of this total inventory, $100 \%$ of the noble gases and $25 \%$ of the iodine is available for immediate release into containment. Furthermore, the released iodine is assumed to be $91 \%$ in the form of elemental iodine $\left(\mathrm{I}_{2}\right), 5 \%$ as particulates (CSI) and the remaining $4 \%$ in 


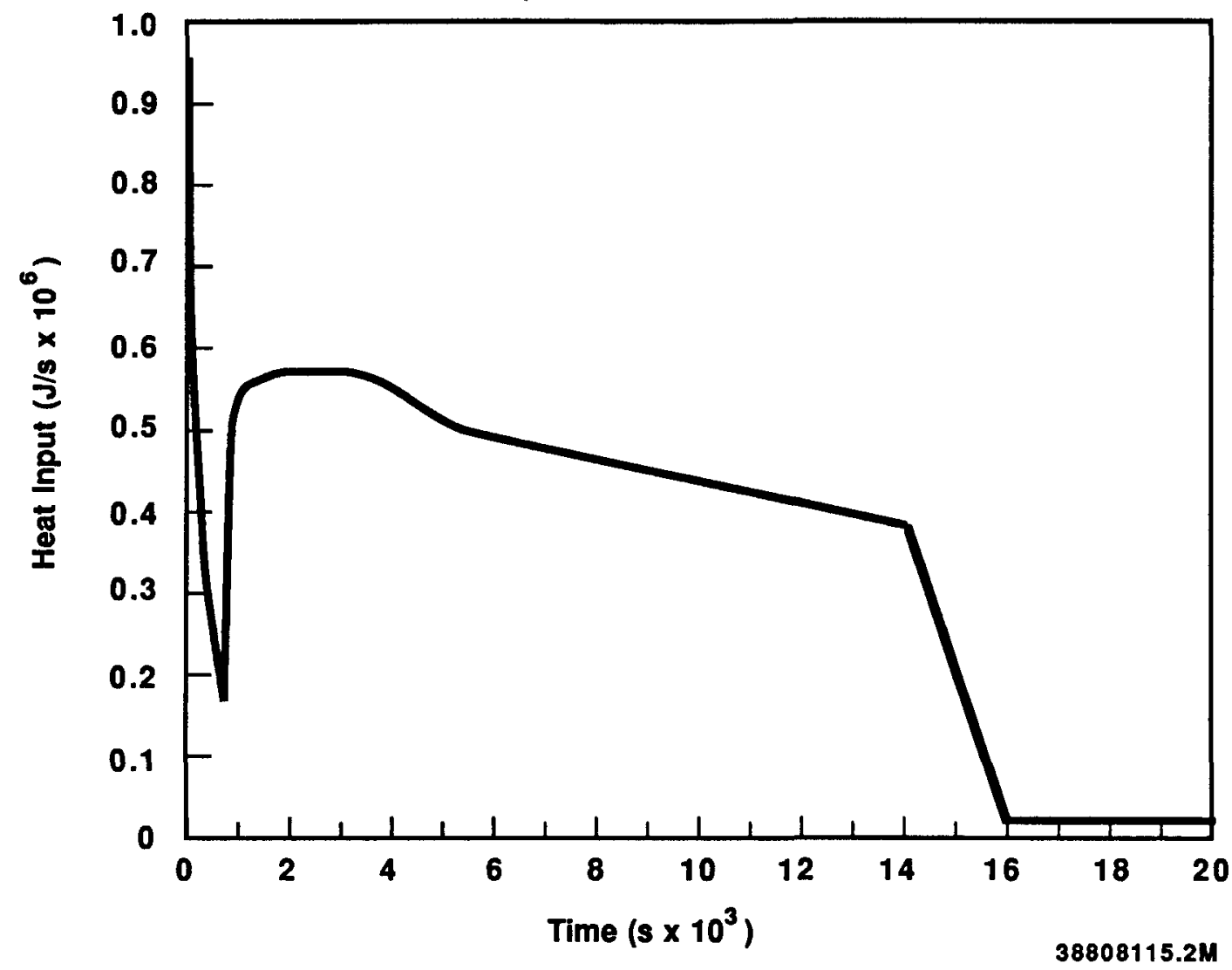

FIGURE H.4. SP-100 Three-Ce11 Mode1: Heat Source.

organic form (methyl iodide). These assumptions are based on the recommendations given in Regulatory Guide $1.4^{(\mathrm{H} .6)}$ for a pressurized water reactor. In accordance with the provision of immediate release, the available inventory of radionuclides was injected into the vacuum vessel atmosphere over the first two minutes of the analysis.

\section{H.11.5 Fission Product Transport and Removal}

All fission product species were assumed to be carried through containment with the atmosphere gas and no credit was taken for settling or plateout en route. The assumption is made, however, that $99.95 \%$ of the particulate 
iodine and $95 \%$ of elemental iodine would be retained on the HEPA filter. This later assumption is based on evidence for the association of elemental iodine with particulate sodium oxidation products. ${ }^{(H .11)}$ It is postulated that, due to the chemical similarity of sodium and lithium, the reaction with lithium products would be approximately the same. No removal of the noble gases or organic iodine is modeled.

\section{H.11.6 Additional Assumptions}

As lithium reacts, there would be a gradual depletion of oxygen and nitrogen from the atmosphere gases. However, for simplicity in calculating the thermal hydraulic transients, this decrease in mass was ignored in this portion of the analysis.

\section{H.12 RESULTS}

Figure $\mathrm{H} .5$ shows the temperature transient in all volumes that results from the release of chemical and decay heat into the vacuum vessel. The temperature in the vacuum vessel rises to a peak of $980^{\circ} \mathrm{C}\left(1800^{\circ} \mathrm{F}\right)$ as the chemical reaction progresses. When the reaction ceases, the temperatures begin to decline as the residual heat is transferred into other volumes.

As gases are exchanged with the reactor cavity, and heat is transferred through the walls of the vacuum vessel, there is a corresponding rise and fall in the gas temperatures in the cavity. The temperature peaks at $275^{\circ} \mathrm{C}$ $\left(525^{\circ} \mathrm{F}\right)$. Because of the 1 arge volume of gases in the containment building and the very slow heat transfer through the thick concrete walls of the reactor cavity, no significant temperature rise in that volume is observed.

As shown in Figure H.6, the pressure in the vessel shows an increase of about $5 \mathrm{kPa}(0.7 \mathrm{psi})$ within $50 \mathrm{~s}$ of the onset of the heat input. As gases flow out of the vessel, however, the pressure rapidly decreases and stabilizes at about $500 \mathrm{~Pa}(0.07 \mathrm{psi})$ above atmospheric within the first half hour. It remains at this value while the reaction continues. 


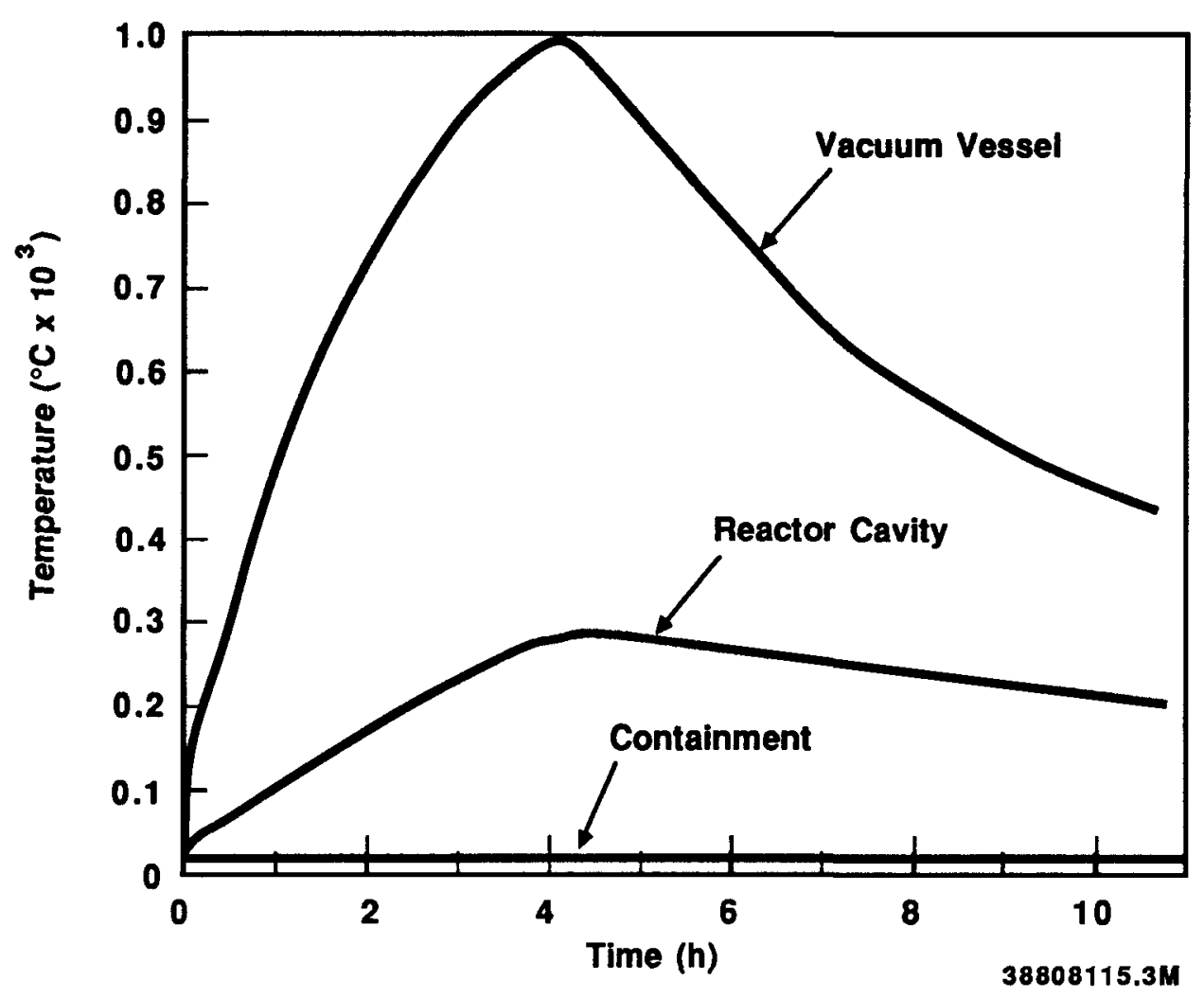

FIGURE H.5. SP-100 Three-Cel1 Model: Cell Temperatures.

The flow of gases through the system and to the outside generally follows the pressure pattern, with initially high flow outward gradually decreasing to very small values as the system equalizes. After the cessation of the reaction, as the system cools, the outward flow stops and flow is inward thereafter.

The resulting release of noble gas and iodine species to the environment is tabulated in Table H.1. The highest releases occur in the first two hours while the flow rates are high. After the flow reverses at around 6 hours, no more releases occur. These values were subsequently used to calculate the radiological consequence to the environment resulting from the postulated accident. 


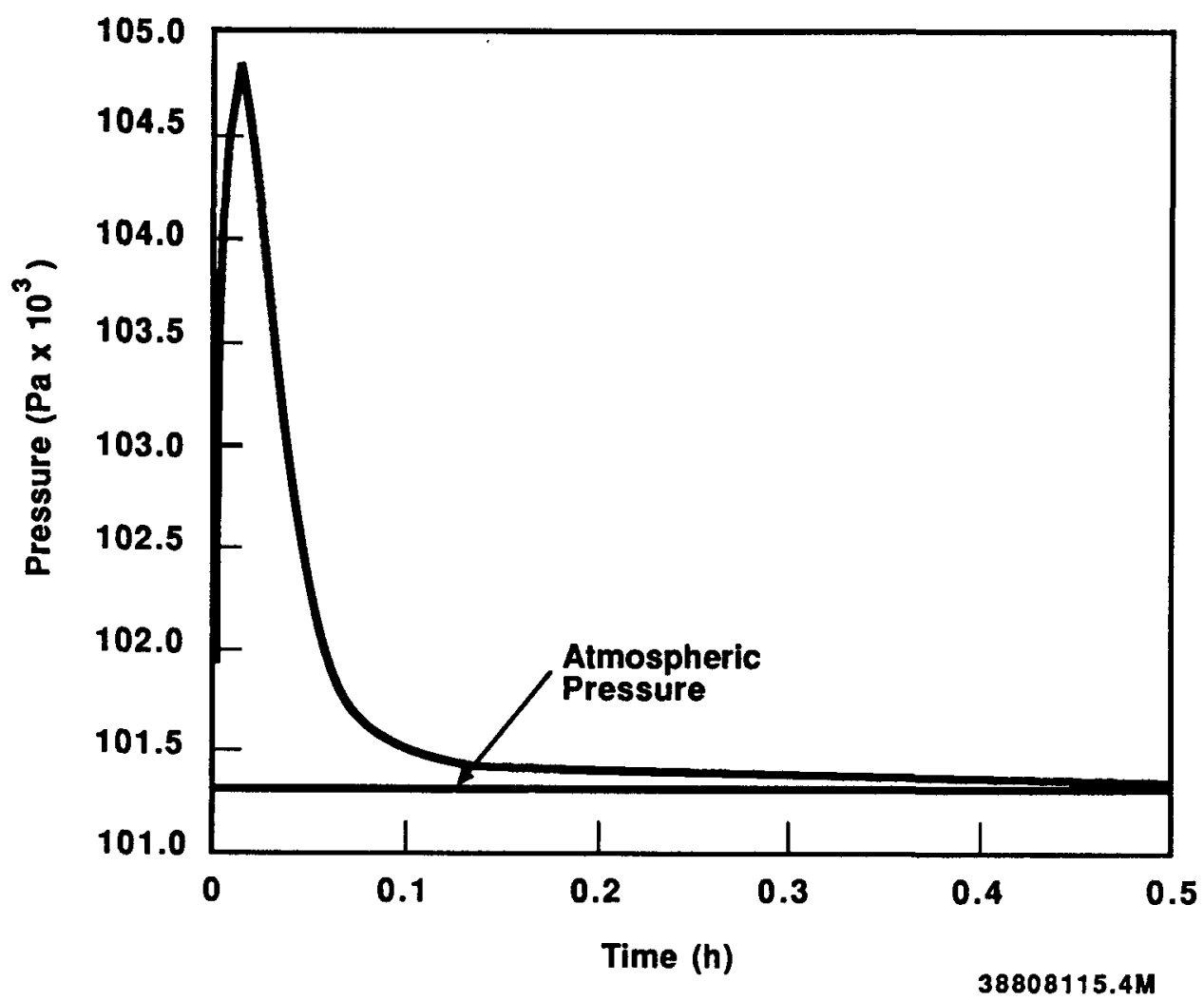

FIGURE H.6. SP-100 Three-Cell Model: Pressure in Vacuum Vessel.

\section{H.13 REFERENCES}

H.3 K. D. Bergeron et al., User's Manual for CONTAIN 1.0, A Computer Code for Severe Nuclear Reactor Accident Containment Analys is, SAND84-1204, NUREG/CR-4085, Sandia National Laboratories, Albuquerque, NM, 1985.

H.4 D. R. Marr, A User's Manual for Computer Code RIBD II, A Fission Product Inventory Code, HEDL-TME 75-26, Westinghouse Hanford Company, Richland, WA, 1985.

H.5 Reference C.8.2 in Appendix C.

H.6 U.S. Nuclear Regulatory Commission Regulatory Guide 1.4, "Assumptions Used for Evaluating the Potential Radiological Consequences of a Loss of Coolant Accident for Pressurized Water Reactors, Rev. 2, "US Nuclear Regulatory Commission, Washington, DC, June 1974.

H.7 L. Baurmash et al., "Behavior of Iodine in the Presence of Sodium Oxide Aerosols," Proceedings of the Eleventh AEC Air Cleaning Conference, Vol. 2, Richland, WA, pp. 373-389, 1970. 
TABLE H. 1

RELEASE OF NOBLE GAS AND IODINE SPECIES

TO THE ENVIRONMENT

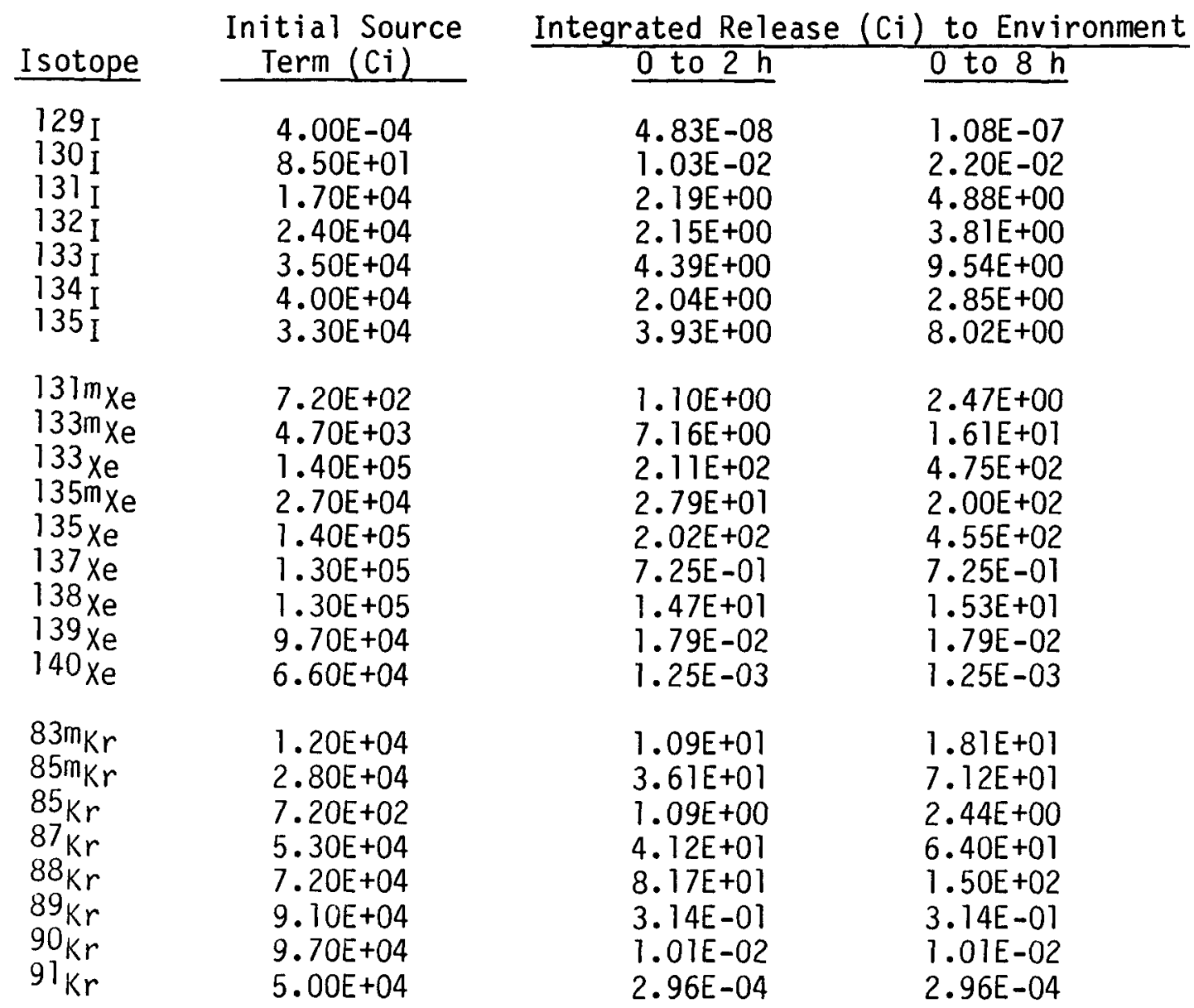




\section{H.14 INTRODUCTION}

The onsite and site boundary radiological doses have been calculated for a beyond design basis accident in the SP-100 facility. The released inventory from the LITFIRE and CONTAIN codes is tabulated in the attached list. The containment analysis assumed an effective containment volume of $43 \%$ of the actual volume to account for incomplete mixing and a one-stage HEPA filter in series with the open containment isolation valves. $95 \%$ of the elemental iodine was assumed to be retained on the HEPA filter due to agglomeration on the $\mathrm{LiOH}$.

\section{H.15 ANALYSIS ASSUMPTIONS}

\section{H.15.1 Release Assumptions}

Source Term: As per attached inventory

Filtration: One-stage HEPA filter - 95\% removal of elemental iodine due to. aglomeration on $\mathrm{LiOH}$

Release Height: Ground level

Release Duration: From start of accident until containment pressure becomes less than atmospheric pressure due to cooling

\section{H.15.2 Transport Assumptions}

Meteorology: 95 percentile worst case

Dispersion Coefficient: Onsite at $100 \mathrm{~m}$, centerline ${ }^{(H .8)}$

$$
X / Q=4.26 \mathrm{E}-2 \mathrm{~s} / \mathrm{m}^{3} \text { for } 0 \text { to } 2 \mathrm{~h}
$$




$$
\begin{aligned}
& \text { Site boundary at } 490 \mathrm{~m} \text {, centerline } \\
& X / Q=4.86 E-3 \mathrm{~s} / \mathrm{m}^{3} \text { for } 0 \text { to } 8 \mathrm{~h} \\
& X / Q=9.54 E-4 \mathrm{~s} / \mathrm{m}^{3} \text { for } 8 \text { to } 24 \mathrm{~h}
\end{aligned}
$$

Wind Speed: $0.78 \mathrm{~m} / \mathrm{s}$

\section{H.15.3 Receptor Assumptions}

Breathing rate: $347 \mathrm{~cm}^{3} / \mathrm{s}$ for 0 to $8 \mathrm{~h}$

$$
175 \mathrm{~cm}^{3} / \mathrm{s} \text { for } 8 \text { to } 24 \mathrm{~h}
$$

Evacuation: Onsite receptor evacuated after $2 \mathrm{~h}$ Site boundary receptor present for duration

Doses Calculated: Whole body $=50-y r$ inhalation dose commitment plus acute external dose from noble gases and iodine (semi-infinite cloud model)
Thyroid $=50-y r$ inhalation dose commitment plus acute external dose from noble gases and iodine (semi-infinite cloud model)

H.16 CODE DOCUMENTATION

Codes Used: DACRIN (Rev. 2, 1980) for inhalation

SUBDOSA (9/87) for submersion doses

Files Addressed: Radionuclide Library (RMDLIB, 1/15/81)

Organ Data Library (2/5/81)

Energy Probability Library (9/87) 
H. 17 RESULTS

At $100 \mathrm{~m}$ (onsite):

\begin{tabular}{|c|c|c|}
\hline \multirow[b]{2}{*}{ Organ } & \multicolumn{2}{|c|}{ Doses (rem) } \\
\hline & \multirow{2}{*}{$\begin{array}{l}\text { Dose Type } \\
\text { Inhalation } \\
\text { Submersion }\end{array}$} & \multirow{2}{*}{$\begin{array}{l}0 \text { to } 2 \text { h } \\
0.103 \\
3.34\end{array}$} \\
\hline Whole Body & & \\
\hline \multirow{3}{*}{ Thyroid } & Total & 3.44 \\
\hline & $\begin{array}{l}\text { Inhalation } \\
\text { Submersion }\end{array}$ & $\begin{array}{c}51.6 \\
3.34\end{array}$ \\
\hline & Total & 54.9 \\
\hline
\end{tabular}

At $490 \mathrm{~m}$ (Hanford Site boundary):

\begin{tabular}{|c|c|c|c|}
\hline \multirow[b]{2}{*}{ Organ } & \multicolumn{3}{|c|}{ Doses (rem) } \\
\hline & Dose Type & 0 to $8 \mathrm{~h}$ & 0 to $8 \mathrm{~h}$ \\
\hline Whole Body & $\begin{array}{l}\text { Inhalation } \\
\text { Submersion }\end{array}$ & $\begin{array}{l}0.026 \\
0.724\end{array}$ & $\begin{array}{l}<0.001 \\
<0.001\end{array}$ \\
\hline & Total & 0.750 & $<0.001$ \\
\hline Thyroid & $\begin{array}{l}\text { Inhalation } \\
\text { Submersion }\end{array}$ & $\begin{array}{c}12.9 \\
0.724\end{array}$ & $\begin{array}{l}<0.001 \\
<0.001\end{array}$ \\
\hline & Total & 13.6 & $<0.001$ \\
\hline
\end{tabular}

H.18 CONCLUSIONS

Sumining dose contributions over the release duration, the results can be summarized as follows: 


\begin{tabular}{cll} 
Distance (m) & \multicolumn{2}{c}{ Dose (rem) } \\
& $\frac{\text { Whole Body }}{3.4(100)}$ & $\frac{55(600)}{4 h y r o i d}$ \\
490 & $0.75(25)$ & $14(300)$
\end{tabular}

Maximum accident dose criteria for an extremely unlikely accident (probability $=10^{-8}-10^{-6} / \mathrm{yr}$ ) are shown in parentheses. Even for this extremely conservative analysis, all resulting doses are well within the criteria for an extremely unikely accident (although this is not required for a Beyond Design Basis Accident).

\section{H.19 REFERENCES}

H.8 Reference C.8.1 in Appendix C.

H.9 W. D. McCormack, J. V. Ramsdell, and B. A. Napier, Hanford Dose Overview Program: Standardized Methods and Data for Hanford Environmenta 1 Dose Calculations, PNL-3777, Rev. 1, Pacific Northwest Laboratory, Richland, WA, May 1984. 
The distribution for this Environmental Assessment included five major categories as shown below.

I. Government

A. Federal

1. United States Senate (Washington State)

2. United States House of Representatives (Washington State)

3. Federal Agencies

- U.S. Environmental Protection Agency (including Region X)

- U.S. Bureau of Indian Affairs

- U.S. Department of Commerce

- U.S. Department of Defense

- U.S. Department of Health and Human Services

- U.S. Department of Interior

- U.S. Department of Transportation

- Office of Management and Budget

4. U.S. Department of Energy

- Field Offices

- Contractors

- General Electric Company

- Westinghouse Hanford Company

B. State

1. Governor of Washington

2. Washington State Department of Ecology

3. Washington State representatives with districts impacted by the proposed action

C. Local Offices and Agencies

1. Benton City Council

2. Richland City Council

3. Pasco City Council

4. Kennewick City Council

5. Benton County Commissioners

6. Franklin County Commissioners 
II. Indian Tribes/Nations

1. Umatilla Confederated Tribes

2. Nez Perce Tribe

3. Wanapum Indian Nation

4. Yakima Indian Nation

II . Libraries

1. Local libraries

2. Regional libraries

3. University libraries (Washington)

4. Freedom of Information Reading Room

IV. Interested Groups/Organizations

A. National Laboratories

1. Jet Propulsion Laboratory

2. Los Alamos National Laboratory

3. Oak Ridge National Laboratory

4. Argonne National Laboratory

5. Idaho National Engineering Laboratory

B. Public Interest Groups

v. Media

Distribution will also be made to all groups and individuals who responded to the published proposed finding of no significant impact. 